"Український ботанічний журнал" публікує статті з усіх напрямів ботаніки та мікології, в тому числі із загальних питань, систематики, флористики, геоботаніки, екології, еволюційної біології, географії, історії флори та рослинності, а також морфології, анатомії, фізіології, біохімії, клітинної та молекулярної біології рослин і грибів. Статті, повідомлення та інші матеріали публікуються в таких основних розділах: "Загальні проблеми, огляди та дискусії", "Систематика, флористика, географія рослин", "Гриби і грибоподібні організми", "Геоботаніка, екологія, охорона рослинного світу", "Червона книга України", "Флористичні знахідки", "Мікологічні знахідки", "Структурна ботаніка", "Фізіологія, біохімія, клітинна та молекулярна біологія рослин", "Гербарна справа", "Історія науки", "Хроніка", "Ювілейні дати", "Втрати науки", "Рецензії та новини літератури".

Статті друкуються українською, англійською та російською мовами

Ukrainian Botanical Journal is a scientific journal publishing articles and contributions on all aspects of botany and mycology, including general issues, taxonomy, floristics, vegetation science, ecology, evolutionary biology, geography, history of flora and vegetation as well as morphology, anatomy, physiology, biochemistry, cell and molecular biology of plants and fungi. Original articles, short communications and other contributions are published in sections "General Issues, Reviews and Discussions", "Plant Taxonomy, Geography and Floristics", "Fungi and Fungi-like Organisms", "Vegetation Science, Ecology, Conservation", "Red Data Book of Ukraine", "Floristic Records", "Mycological Records", "Structural Botany", "Plant Physiology, Biochemistry, Cell Biology and Molecular Biology", "Herbarium Curation", "History of Science", "News and Views", "Anniversary Dates", "In Memoriam", "Reviews and Notices of Publications".

Publication languages: Ukrainian, English and Russian

\section{РЕДАКЦІЙНА КОЛЕГІЯ}

Головний редактор - Сергій Л. МОСЯКІН

Заступники головного редактора - Ганна В. БОЙКО, Віра П. ГАЙОВА

Раїса І. БУРДА, Соломон П. ВАССЕР, Філіп ВЕРЛООВ (Бельгія), ВасиЛь П. ГЕЛЮТА, Зігмантас ГУДЖИНСКАС (Литва), Яків П. ДІДУХ,

Дмитро В. ДУБИНА, Олена К. ЗОЛОТАРЬОВА,

Сергій Я. КОНДРАТЮК, Елізавета Л. КОРДЮМ, Ірина А. КОРОТЧЕНКО, Ірина В. КОСАКІВСЬКА, Кароль МАРГОЛЬД (Словаччина), Евіатар НЕВО (Ізраїль), Віктор І. ПАРФЬОНОВ (Білорусь), Пітер РЕЙВЕН (США), Марина М. СУХОМЛИН, СусумУ ТАКАМАЦУ (Японія), Микола М. ФЕДОРОНЧУК, Олександр Є. ХОДОСОВЦЕВ, Петро М. ЦАРЕНКО, ІЛЛЯ І. ЧОРНЕЙ, Мирослав В. ШЕВЕРА, Юрій Р. ШЕЛЯГ-СОСОНКО, Наталія М. ШИЯН, Богдан ЯЦКОВЯК (Польща) Відповідальний секретар Марія Д. АЛЕЙНІКОВА

\section{EDITORIAL BOARD}

Editor-in-Chief - Sergei L. MOSYAKIN

Associate Editors - Ganna V. BOIKO Vera P. HAYOVA

Raisa I. BURDA, Illya I. CHORNEY, Yakiv P. DIDUKH, Dmytro V. DUBYNA, Mykola M. FEDORONCHUK, Zigmantas GUDŽINSKAS (Lithuania), Vasyl P. HELUTA, Bogdan JACKOWIAK (Poland), Olexander E. KHODOSOVTSEV, Sergei Y. KONDRATYUK, Elizabeth L. KORDYUM, Iryna A. KOROTCHENKO, Iryna V. KOSAKIVSKA, Karol MARHOLD (Slovakia), Eviatar NEVO (Israel), Victor I. PARFENOV (Belarus), Peter RAVEN (USA), Yuriy R. SHELYAG-SOSONKO, Myroslav V. SHEVERA, Natalia M. SHYIAN, Maryna M. SUKHOMLYN, Susumu TAKAMATSU (Japan), Petro M. TSARENKO, Filip VERLOOVE (Belgium), Solomon P. WASSER, Olena K. ZOLOTAREVA

Editorial Assistant - Mariya D. ALEINIKOVA

На першій сторінці обкладинки: Xanthoria polessica S.Y. Kondr. \& A.P. Yatsyna - ендемічний вид Східної Европи. Фото ( С Сергій Я. Кондратюк

Front page: Xanthoria polessica S.Y. Kondr. \& A.P. Yatsyna, an endemic species of Eastern Europe. Photo by (C) Sergei Ya. Kondratyuk

Редакція "Українського ботанічного журналу"

Інститут ботаніки НАН України

вул. Терещенківська 2, Київ 01004, Україна
(044) 235-41-82

secretary_ubzh@ukr.net

https://ukrbotj.co.ua 


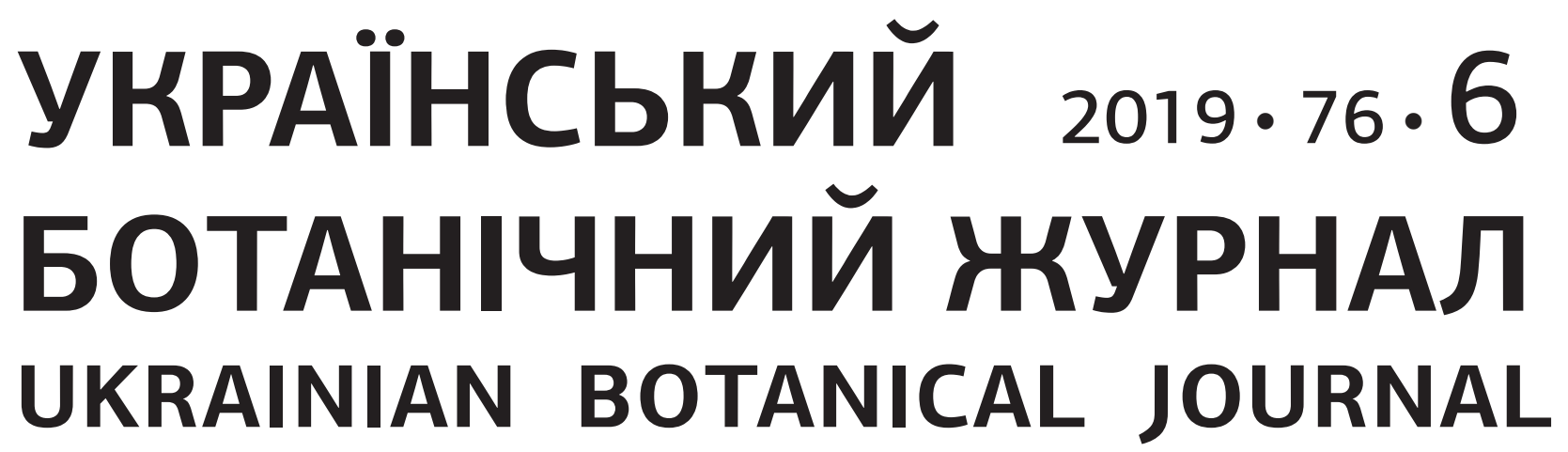

НАУКОВИЙ ЖУРНАЛ • ЗАСНОВАНИЙ 1921 р. • SCIENTIFIC JOURNAL • PUBLISHED SINCE 1921

\section{M I C T}

\section{Систематика, флористика, географія рослин}

Мосякін С.Л., Шиян Н.М. Номенклатурні і таксономічні нотатки про Jacobaea borysthenica (Asteraceae) та деякі споріднені таксони . . . . . . . . . . . . . . . . . . . . . . . . . . . . . . . . . . . . . . . . . . . . 473

\section{Гриби і грибоподібні організми}

Бороменський Д.О., Бісько Н.А. Мікроморфологічні особливості грибів роду Ganoderma (Ganodermataceae) в

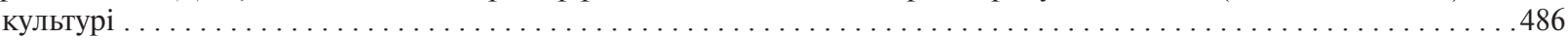

Пасайлюк М.В. Біологічні особливості рідкісного гриба Sparassis nemecii (Sparassidaceae, Polyporales) на рослинних субстратах в чистій культурі . . . . . . . . . . . . . . . . . . . . . . . . . . . . . . . . . . 493

Геоботаніка, екологія, охорона рослинного світу

Дубина Д.В., Ємельянова С.М., Дворецький Т.В., Дзюба Т.П., Тимошенко П.А. Адвентизація ценофлор класів піонерної рослинності України . . . . . . . . . . . . . . . . . . . . . . . . . . . . . . . . . . . . . . . . . . 499

Конайкова В.О. Угруповання класу Festuco-Brometea природного заповідника "Єланецький степ" . . . . . . . . . . . 511

\section{Червона книга України}

Ролечек Я., Држевоян П. Нові дані щодо поширення зникаючого виду Viola jooi (Violaceae) в Україні . . . . . . . . . . 526

Попович С.Ю., Михайлович Н.В., Грисюк Т.С. Репрезентованість Pinus cembra (Pinaceae) в природно-

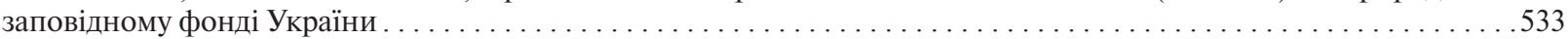

\section{Флористичні знахідки}

Орлов О.О., Якушенко Д.М., Маєкова Я., Заліберова М., Протопопова В.В., Андрик Є.Й., Шевера М.В. Galeopsis angustifolia (Lamiaceae) - новий адвентивний вид у флорі України . . . . . . . . . . . . . . . . . . . . . . . . . .5542

Куземко А.А., Яворська О.Г., Ковтонюк А.I. Cephalaria gigantea (Caprifoliaceae) - новий адвентивний вид флори

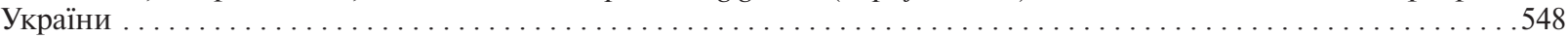

Кривошея О.М., Капустін Д.О. Нові знахідки діатомових водоростей для альгофлори України з водойм

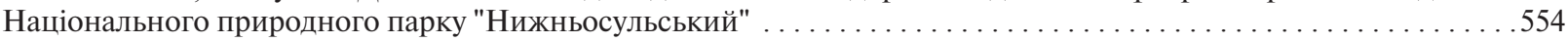

\section{Ювілейні дати}

Гелюта В.П., Придюк М.П., Михайлова О.Б., Аль-Маалі Г.А., Андріанова Т.В., Гайова В.П., Ломберг М.Л., Митропольська Н.Ю., Тихоненко Ю.Я., Зикова М.О., Шевченко М.В., Мосякін С.Л. Ніна Анатоліївна Бісько (до 70-річчя від дня народження та 50-річчя наукової діяльності) . . . . 


\section{Втрати науки}

Білявський С.М., Журавель Н.М., Протопопова В.В., Когут Е.І., Шевера М.В. Пам'яті видатного педагога та

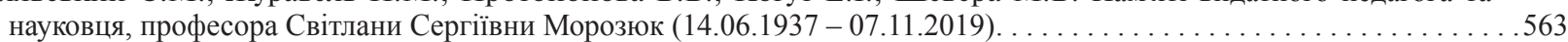

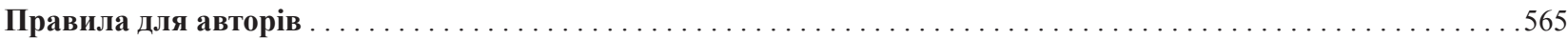

Покажчик статей, опублікованих в "Украйнському ботанічному журналі" в 2019 році ................570

\section{CONTENTS}

\section{Plant Taxonomy, Geography and Floristics}

Mosyakin S.L., Shiyan N.M. Nomenclatural and taxonomic notes on Jacobaea borysthenica (Asteraceae) and some

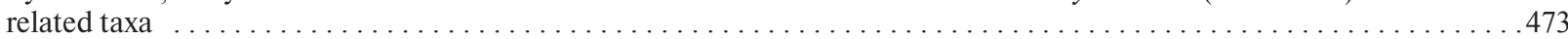

\section{Fungi and Fungi-like Organisms}

Boromenskyi D.O., Bisko N.A. Micromorphological features of species of Ganoderma (Ganodermataceae) in pure

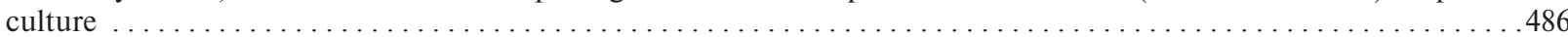

Pasailiuk M.V. Biological peculiarities of a rare mushroom Sparassis nemecii (Sparassidaceae, Polyporales) on plant

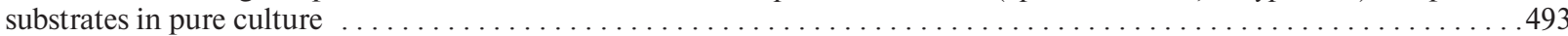

\section{Vegetation Science, Ecology, Conservation}

Dubyna D.V., Iemelianova S.M., Dvoretzkiy T.V., Dziuba T.P., Tymoshenko P.A. Adventization of coenofloras of the

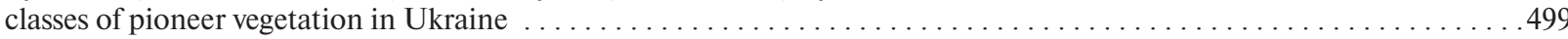

Konaikova V.O. Communities of the class Festuco-Brometea in Yelanetskyi Step Nature Reserve.................511

\section{Red Data Book of Ukraine}

Roleček J., Dřevojan P. New data on distribution of the endangered species Viola jooi (Violaceae) in Ukraine ... 526

Popovych S.Yu., Mykhaylovych N.V., Hrysiuk T.S. Representativity of Pinus cembra (Pinaceae) in natural protected fund of Ukraine . . . . . . . . . . . . . . . . . . . . . . . . . . . . . . . . . . . . . . . . . . . . . . . . . . 533

\section{Floristic Records}

Orlov O.O, Iakushenko D.M., Májeková J., Zaliberová M., Protopopova V.V., Andrik E.J., Shevera M.V. Galeopsis

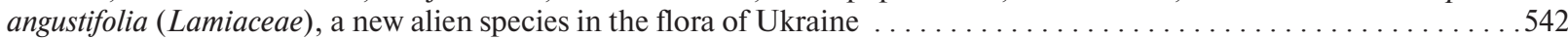

Kuzemko A.A., Yavorska O.G., Kovtoniuk A.I. Cephalaria gigantea (Caprifoliaceae), a new alien species in the flora

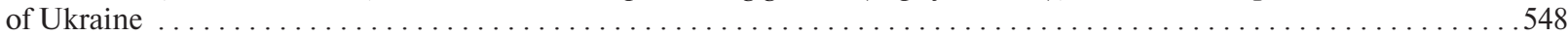

Kryvosheia O.M., Kapustin D.O. New records of diatoms for the algal flora of Ukraine from water bodies of Nyzhniosulsky

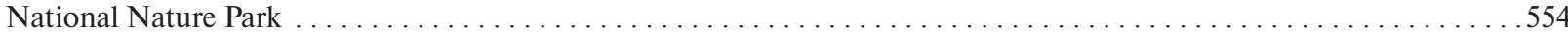

\section{Anniversariy Dates}

Heluta V.P., Prydiuk M.P., Mykhailova O.B., Al-Maali G.A., Andrianova T.V., Hayova V.P., Lomberg M.L., Mytropolska N.Yu., Tykhonenko Yu.Ya., Zykova M.O., Shevchenko M.V., Mosyakin S.L. Nina A. Bisko (on the $70^{\text {th }}$ anniversary of her birth and $50^{\text {th }}$ anniversary of scientific activities) $\ldots \ldots \ldots \ldots \ldots \ldots .560$

\section{In Memory}

Bilyavskyi S.M., Zhuravel N.M., Protopopova V.V., Kohut E.I., Shevera M.V. In memory of a well-known pedagogue and

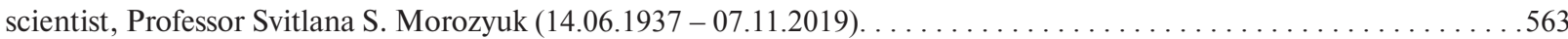

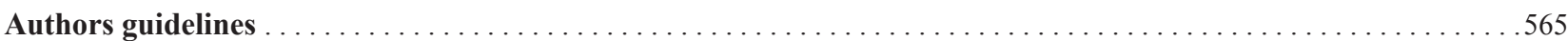

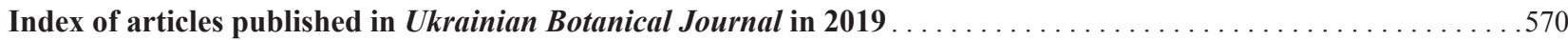


https://doi.org/10.15407/ukrbotj76.06.473

\title{
Nomenclatural and taxonomic notes on Jacobaea borysthenica (Asteraceae) and some related taxa
}

\author{
Sergei L. MOSYAKIN, Natalia M. SHIYAN \\ M.G. Kholodny Institute of Botany, National Academy of Sciences of Ukraine \\ 2 Tereschenkivska Str., Kyiv 01004, Ukraine \\ s_mosyakin@hotmail.com
}

Mosyakin S.L., Shiyan N.M. 2019. Nomenclatural and taxonomic notes on Jacobaea borysthenica (Asteraceae) and some related taxa. Ukrainian Botanical Journal, 76(6): 473-485.

Abstract. Following our recent lectotypification (with a specimen from G-DC) of the name Senecio praealtus Bertol. var. borysthenicus DC. validated by de Candolle based on Andrzejowski's and Besser's specimens from Ukraine, we provide here information on additional original specimens of that taxon (KW: Besser and Turczaninow historical collections), which is now recognized as Jacobaea borysthenica (DC.) B.Nord. \& Greuter and which was until recently widely accepted as Senecio borysthenicus (DC.) Andrz. ex Czern. (Asteraceae). In particular, there are two isolectotypes in KW collected by Andrzejowski near Kyslyakivka (now Lymany, Mykolayiv Region, Ukraine), as well as some other specimens collected near Zaporizhzhya (Andrzejowski) and in southern Podolia (Besser and/or Andrzejowski). Some related Eastern European taxa of the taxonomically complicated Jacobaea vulgaris Gaertn. (= Senecio jacobaea L.) aggregate and misapplied names are discussed as well. The identity of the name Senecio divaricatus Andrz. (nom. illeg., non L.) is clarified; it is a synonym of Jacobaea borysthenica. It is also confirmed that Senecio podolianus Panigrahi is an illegitimate replacement name for S. borysthenicus. Jacobaea borysthenica seems to be closely related to J. andrzejowskyi (Tzvelev) B. Nord. \& Greuter and J. vulgaris subsp. pannonica Hodálová \& Mered'a; the two latter taxa morphologically differ from J. borysthenica but are very similar to each other and may be even conspecific. Further studies are needed for clarifying the complex evolutionary and biogeographical patterns within the $J$. vulgaris aggregate in Eastern Europe and adjacent areas.

Keywords: Asteraceae, herbarium, Jacobaea, nomenclature, Senecio, taxonomy, Ukraine

Supplementary Material. Electronic Supplement (Figures E1-E4, e1-e4) is available in the online version of this article at: https://ukrbotj.co.ua/archive/76/6/473

Submitted 03 October 2019. Published 29 December 2019

Мосякін С.Л., Шиян Н.М. 2019. Номенклатурні і таксономічні нотатки про Jacobaea borysthenica (Asteraceae) та деякі споріднені таксони. Украӥнський ботанічний журнал, 76(6): 473-485.

Інститут ботаніки ім. М.Г. Холодного НАН України

вул. Терещенківська 2, Київ 01004, Україна

Реферат. На доповнення до нещодавно проведеної нами лектотипіфікації назви Senecio praealtus Bertol. var. borysthenicus DC. (зразок з гербарію G-DC), що була запропонована О.П. де Кандоллем на основі зразків А.Л. Анджейовського та В.Г. Бессера з України, ми подаємо тут інформацію про додаткові оригінальні зразки цього таксона (KW: історичні гербарні колекції Бессера та Турчанінова), який зараз розглядається як Јасоьаеа borysthenica (DC.) B.Nord. \& Greuter, а донедавна широко визнавався як Senecio borysthenicus (DC.) Andrz. ex Czern. (Asteraceae). Зокрема, у гербарії KW виявлено два ізолектотипи, зібрані Анджейовським біля Кисляківки (зараз Лимани, Миколаївська область, Україна), а також деякі інші зразки, зібрані біля Запоріжжя (Анджейовський) та на півдні Поділля (Бессер та/або Анджейовський). Обговорені деякі споріднені східноєвропейські таксони зі складу систематично складної групи Jacobaea vulgaris Gaertn. (= Senecio jacobaea L.) aggr., а також назви, що були невірно застосовані до нашого таксона. Прояснено таксономічний статус Senecio divaricatus Andrz. (nom. illeg., non L.): ця назва є синонімом Jacobaea borysthenica. Підтверджено, що Senecio podolianus Panigrahi є незаконною назвою, помилково запропонованою на заміну S. borysthenicus. Ймовірно, що вид Jacobaea borysthenica близько споріднений $з$ J. andrzejowskyi (Tzvelev) B.Nord. \& Greuter та J. vulgaris subsp. pannonica Hodálová \& Меred'а; два останні морфологічно відмінні від J. borysthenica, але дуже подібні між собою, а може й належать до одного й того ж виду. Потрібні подальші дослідження для виявлення складної еволюційної та біогеографічної картини у межах видового комплексу J. vulgaris aggr. у Східній Європі та на прилеглих територіях.

Ключові слова: Asteraceae, Jacobaea, Senecio, гербарій, номенклатура, систематика, Україна

(C) 2019 S.L. Mosyakin, N.M. Shiyan. Published by the M.G. Kholodny Institute of Botany, NAS of Ukraine. This is an open access article under the terms of the Creative Commons Attribution License (http://creativecommons.org/licenses/by/4.0/), which permits use, distribution, and reproduction in any medium, provided the original work is properly cited 


\section{Introduction}

The present nomenclatural and taxonomic contribution is a continuation of our earlier publications on East European taxa of the species aggregate of Jacobaea vulgaris Gaertn. (= Senecio jacobaea L.) (see Mosyakin, Yena, 2017; Mosyakin, 2018 dated "2017"; Mosyakin et al., 2019). In particular, in our recent article (Mosyakin et al., 2019) we designated the lectotype for Senecio praealtus Bertol. var. borysthenicus DC., the basionym of the currently accepted name Jacobaea borysthenica (DC.) B. Nord. \& Greuter, but some nomenclatural and taxonomic details and considerations on that species remained beyond the scope of our short nomenclatural note. These additional details and considerations are provided below.

Senecio borysthenicus (DC.) Andrz. ex Czern. (originally described as $S$. praealtus Bertol. var. borysthenicus DC.: see de Candolle, 1838 dated "1837") was widely and readily recognized as a species in many East European taxonomic treatments, floras and identification manuals (Gruner, 1869 dated "1868"; Taliev, 1935; Stankov, Taliev, 1949; Schischkin, 1961 [English translations: Shishkin, 1995; Schischkin, 2000]; Minderova, 1962; Privalova, 1969; Chater, Walters, 1976; Tzvelev, 1986; Katina, 1987; Konechnaya, 1994; Mosyakin, Fedoronchuk, 1999; Kucherevs'kiy, 2004; Tarasov, 2012; etc.). The species-rank combination in Senecio was validated by Czerniaëw (1859: 32) by indirect reference, as Senecio "748. Borysthenicus. Andrz. Ch. In arenosis", where "Ch." means "Charkovia" (Kharkiv) (see details in Mosyakin et al., 2019).

In earlier literature that taxon was often recognized as a variety, $S$. jacobaea var. borysthenicus (DC.) Trautv. (Trautvetter, 1854, 1855; Schmalhausen, 1886, 1897; Rogowicz, 1869), or as $S$. praealtus var. borysthenicus (e.g., Ledebour, 1845), but the authorship of the first variety was cited differently in various publications. We confirmed (Mosyakin et al., 2019) that the variety-rank combination has been validated by Trautvetter (1854), not by Gruner (1869 dated "1868") or Schmalhausen (1886). Andrzejowski (1862), being probably unaware of the article by Trautvetter (1854), used the same variety name, as "S. Jacobaea var. borysthenicus Andrz.". However, his text of 1862 is in need of a more thorough analysis, which is provided below.

Recently Ciocârlan (2009: 815) proposed the subspecies-rank combination, Senecio jacobaea L. subsp. borysthenicus (DC.) Ciocârlan (comb. inval., sine basion.). However, keeping this taxon in the genus Senecio is not in accordance with new phylogenetic data and the currently accepted taxonomic delimitation of genera in Senecioneae (see Pelser et al., 2007; Nordenstam et al., 2009, etc.).

Molecular phylogenetic studies demonstrated that Jacobaea Mill. (validated by Miller, 1754) deserves recognition as a separate genus quite distant phylogenetically from Senecio L. sensu stricto (Pelser et al., 2002, 2004, 2007, 2010; Nordenstam, 2007; Nordenstam et al., 2009, etc.), and because of that $S$. borysthenicus was transferred to Jacobaea as J. borysthenica (DC.) B. Nord. \& Greuter (in Greuter, Raab-Straube, 2006), together with many other taxa earlier treated in Senecio (see relevant nomenclatural actions in Pelser et al., 2006; Nordenstam, 2006, Greuter, Raab-Straube, 2006, 2007; Verloove, Lambinon, 2011; Mosyakin, Yena, 2017, etc.). The name Jacobaea borysthenica is currently accepted in botanical literature and databases (Greuter, 2006-onward; Greuter, Raab-Straube, 2008; Ostapko et al., 2010; Shapoval, 2012; Yena, 2012; Onyschenko et al., 2017; POWO, 2019-onward).

The species aggregate Jacobaea vulgaris is rather problematic taxonomically; it contains various poorly delimited and closely related taxa treated either as species or infraspecific entities (see Wysk et al., 2009; Hodálová et al., 2010, 2015; Mered'a et al., 2016, etc.).

Judging from available evidence, Jacobaea borysthenica occurs in southern regions of Eastern Europe, mainly in sandy steppe and alluvial habitats along river valleys in southern and central regions of Ukraine and adjacent areas of the southwestern European part of Russia (Schischkin, 1961; Minderova, 1962; Tzvelev, 1986; Konechnaya, 1994; Katina, 1987; Kucherevs'kiy, 2004; Tarasov, 2012). This species is also reported from Romania (Popescu, 1972, 1973; Ciocârlan, 2009, 2011; Doroftei et al., 2011; Negrean, 2011) and Belarus (Parfenov et al., 1987; Tretyakov, 1999). In our opinion, Belarusian records need confirmation. At least, we have not seen any reliable specimens of $J$. borysthenica from Belarus. In addition to confirmed records from Ukraine, Romania, and Russia, the species most probably also occurs in Moldova because it is reliably recorded in the nearby territories in Ukraine; however, it is not reported in Geideman (1986 and earlier editions).

Jacobaea borysthenica is listed (as Senecio borysthenicus) as a regionally protected species in Dnipropetrovsk (Dnipro), Donetsk, Luhansk 
(Lugansk), and Odesa (Odessa) administrative regions (oblas'ts) of Ukraine (Andrienko, Peregrym, 2012) and is considered a rare and threatened plant in Romania (Făgăraş et al., 2010). It was included in the second edition of the Red Data Book of the Republic of Belarus (Darafeev et al., 1993; see also Parfenov et al., 1987), but is not listed anymore in the third edition (Horuzhyk et al., 2005) because the species was re-considered as an alien in Belarus.

Types of Ukrainian species of Senecio sensu lato were considered by Shiyan et al. (2013) but the name Senecio praealtus var. borysthenicus was effectively lectotypified only recently (Mosyakin et al., 2019), with the specimen G00471753 from the de Candolle Herbarium (G-DC, Conservatoire et Jardin botaniques, Genève, Switzerland). The name $S$. praealtus Bertol. was lectotypified earlier by Iamonico and Managlia (2015).

The herbarium acronyms here and below are given following Index Herbariorum (Thiers, 2008-onward).

\section{Original specimens (syntypes) in G-DC}

De Candolle (1838 dated "1837": 351) provided the following geographical information for his "S. praealtus $\beta$ Borysthenicus": "in pratis Podoliæ, Cherson. Russiæ circ. Borysth. (Bess.!). Sen. Borysthenicus Andrz. ex Bess. in litt. (v. s.)". This information corresponds to some areas in the Podolian Governorate of the former Russian Empire ("in pratis Podoliæ") and the Kherson Governorate near the Dnipro River ("Cherson. Russiæ circ. Borysth."). The specimens (two collected by Andrzejowski, one by Andrzejowski or Besser; see Mosyakin et al., 2019) were provided to de Candolle by Besser, most probably in 1831 . The three original specimens (syntypes) are currently deposited in the de Candolle Herbarium (G-DC), with the following labels:

G00471752: "Senecio affinis tenuifolio [\&?] borysthenico. Kislakowka. Gub. Cherson. DC 1831 [the year of provenance by de Candolle - S.M.]. Herb. W. Besser";

G00471753: "Senecio borysthenicus Andrz. circa Kislakowka gub. Cherson. 27 [meaning 1827; most probably the year of provenance by Besser - S.M.] DC. 1831 [the year of provenance by de Candolle S.M.]. Herb. W. Besser"; there is also a small envelope with parts of inflorescences and flowers and the inscription "ach. radii striata glabra disci puberula" (by Candolle) corresponding to the phrase "achæniis radii glabris disci puberis" used by Candolle in his description of S. praealtus (Candolle, 1838 dated "1837": 351); the label pinned in the bottom right corner of the sheet with the name "Senecio Borysthenicus Andrz.!" (by Candolle) belongs to all three syntypes;

G00471754: "Senecio tenuifolius? involucri squamis enerv. ciliatis apice spha... [ending of the word illegible, probably "sphacelatis"? - S.M.], bracteis copiosis lineario-lanceolatis. E pratis Pod[olia]. austr. 1831 [the year of provenance by de Candolle, added in darker ink - S.M.]. Herb W. Besser".

Blue labels with typographically printed words "Herb. W. Besser" mounted on the three mentioned specimens are printed on the blue paper that seems to be identical to the paper used for publication of the first edition of Besser's Catalogue (Besser, 1810)]

The three syntypes cited above and specifically the lectotype (G00471753) are discussed in our lectotypification note (Mosyakin et al., 2019). However, several other original specimens collected and annotated as Senecio borysthenicus by Besser and/or Andrzejowski are currently deposited in the Besser and Turczaninow historical collections in the National Herbarium of Ukraine (KW, Herbarium of the M.G. Kholodny Institute of Botany, National Academy of Sciences of Ukraine, Kyiv); these specimens deserve additional discussion, which is provided below.

\section{Original and some other historical specimens in the Besser and Turczaninow memorial collections at KW}

Specimens in the Turczaninow herbarium (KWTURCZ). One specimen from the Turczaninow herbarium has the characteristic blue label of Besser: "Senecio borysthenicus Andrzej. Circa Kislakowka, Gub. Cherson. Herb. W. Besser" (KW001002876, Fig. 1). The village of Kyslyakivka (now Lymany in Vitovs'ky District of Mykolayiv Region, southern Ukraine) was located on the shore of the Southern Bug Estuary (Бузький лиман in Ukrainian) near its confluence with the Dnipro (Dnieper) Estuary (Дніпровський лиман in Ukrainian), in the former Kherson Governorate. It was mentioned as"Kiślakówka" by Andrzejowski in Chapter 2 "Kraina wapienna $i$ nadmorska" ("The limestone and seashore land") of his Rys botaniczny... (Andrzejowski, 1823: 23). Another specimen in the same folder has the white label "Senecio borysthenicus Andrzej. Senecio praealtus $\beta$ : [the second identification was added in darker ink, evidently after de Candolle's publication - S.M.]. Ad Cataractas fl. Borysthen. Herb. W. Besser" (KW001002877, Fig. E1, Electronic Supplement). It was evidently collected somewhere near the Dnipro cataracts, most probably in the present-day Zaporizhzhya Region of Ukraine. 


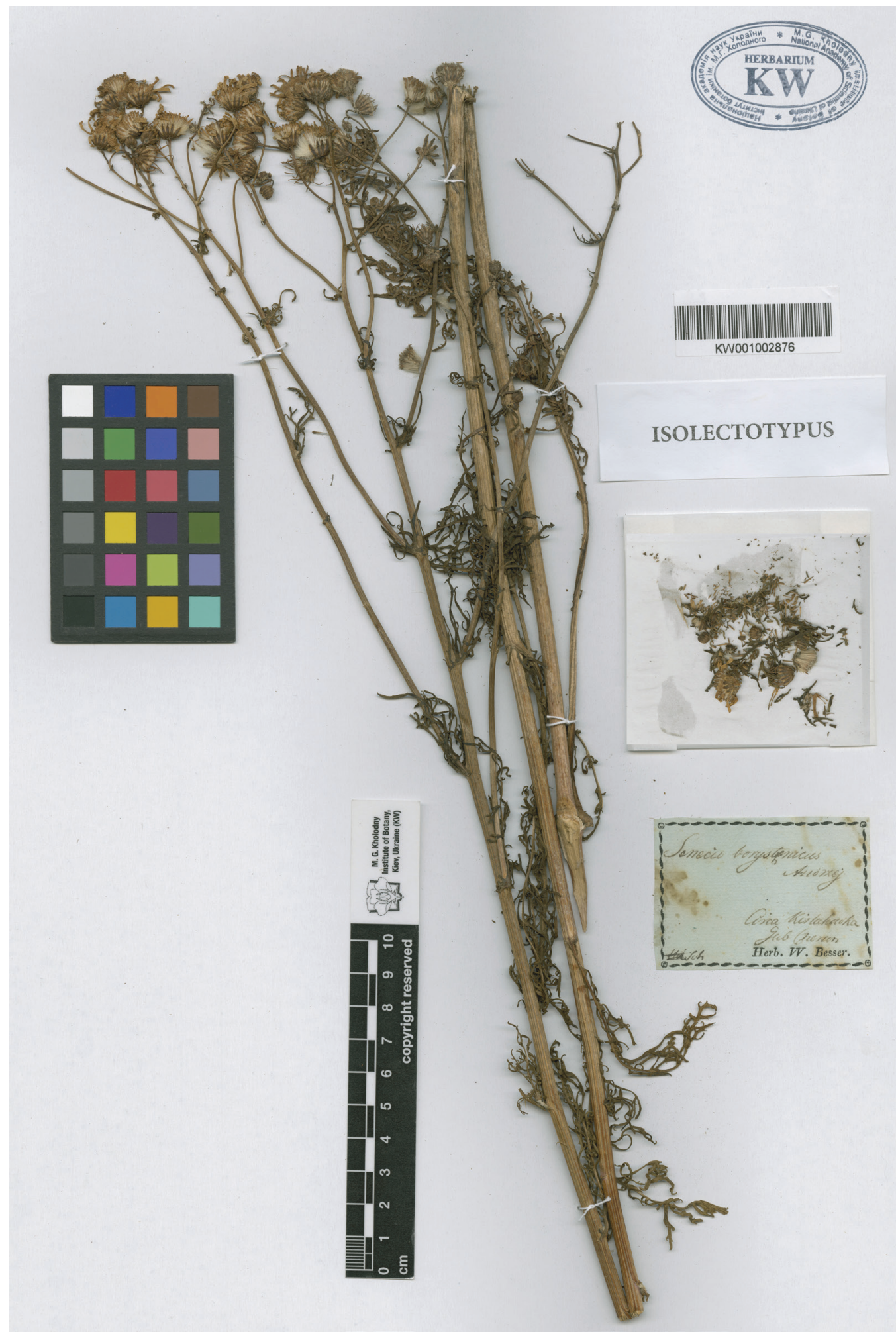

Figure 1: Isolectotype of Jacobaea borysthenica (Senecio praealtus var. borysthenicus, S. borysthenicus) from the Turczaninow historical herbarium at KW, collected by Andrzejowski near Kyslyakivka (now Lymany, Vitovs'ky District, Mykolayiv Region, Ukraine), KW001002876 
Both plants (KW001002876 and KW001002877) taxonomically belong to Jacobaea borysthenica, and the first specimen can be regarded as an isolectotype.

The specimen KW001002882 (Fig. E2, Electronic Supplement) collected by Andrzejowski is labeled as "Senecio Borysthenicus Nob. in saxosis ad Borysthenum inter Cortitz et Sienilnikowa". These localities are in need of some comments. Andrzejowski (1830: 42) mentioned "wyspa Cortitz" (Khortytsya Island on the Dnipro, within the present-day city of Zaporizhzhya) and further commented that the settlement of German [Mennonite] colonists known as Cortitz. Einlage was called Kichkas (Kiczkas in Polish) by locals ("kolonija nazwana od Niemców Cortitz Einlage u krajowców Kiczkas": Andrzejowski, 1830: 43). It was also mentioned in French in Andrzejowski's geological contribution as "la Colonie allemande Cortitz Einlage nommée chez les habitans [sic! - S.M.] Kiezkas (Quitschekase)" (Andrzejowski, 1850: 216). Andrzejowski (1830: 51) also visited "cały wzgórek od Wołnichii do Sienilnikowey", and these toponyms probably refer to Vil'nyanka village or the nearby town of Vil'nyansk (formerly also known as Sofiyivka) in Zaporizhzhya Region, and the present-day village of Ivanivka (formerly Ivanivs'ke Synel'nykove). In our opinion, "Sienilnikowa" mentioned by Andrzejowski should not be confused with the present-day town of Synel'nykove, Dnipropetrovsk Region, ca. 75 km from Zaporizhzhya; at the time of Andrzejowski's travels it was probably just a small village. Thus, both "Cortitz" and "Sienilnikowa" refer to the present-day city of Zaporizhzhya and adjacent areas.

The same folder contained two additional specimens collected by Czerniaëw (also variously transliterated as Chernyaev, Tschernaiew, Czerniaiev, or Czernajew) in the eastern part of Ukraine (KW001002878: "Starobielsk et Charcow" - now Starobil'sk in Luhansk Region, and Kharkiv in Kharkiv Region, Ukraine) and in an adjacent part of Russia on the Don River (KW001002879: "ad Tanain"). However, these poorly preserved specimens do not belong to the original material of $S$. praealtus var. borysthenicus. Moreover, morphologically they differ from Jacobaea borysthenica and belong to J. vulgaris sensu lato. The sheet KW001002878 contains four plant fragments: two of them are evidently parts of the same plant (probably collected in or near Kharkiv? identifiable as $J$. vulgaris) and the other two (upper parts with inflorescences, mounted on the left side of the sheet, probably collected in Starobil'sk?) are morphologically different from the right-side plant. It looks like there are two collections with one label, and some plant fragments (collected in Starobil'sk?) may in fact belong to the taxon now known as $J$. andrzejowskyi (Tzvelev) B. Nord. \& Greuter (in Greuter, RaabStraube, 2006: 712). Despite the partial misapplication of the name Senecio borysthenicus, Czerniaëw validly published the species-rank combination (see above).

Specimens in the Besser herbarium (KW-BESS). The original folder annotated as "Sen. Jacobaea $\beta$ Borysthenicus" in the Besser herbarium (KW) contained 12 unmounted specimens and plant fragments collected in Ukraine (the Dnieper cataracts near the present-day Zaporizhzhya, "Tauria", "Podolia", etc.), most of which indeed belong to $J$. borysthenica. However, at least two specimens are identifiable as J. erucifolia (L.) G.Gaertn., B.Mey. \& Scherb. sensu lato (incl. J. grandidentata (Ledeb.) Vasjukov), which probably reflects the uncertainly in Besser's understanding of the identity of these taxa; these plants were collected in "Tauria" (most probably Crimea) and in "Cherson" or "Podolia" (two labels in one specimen, one label was probably misplaced). Additional information is provided below on selected specimens with original informative labels and original annotations.

The specimen KW001002880 (Fig. 2) from the Besser herbarium was collected in the same locality as the lectotype of Senecio praealtus var. borysthenicus (formerly Kyslyakivka, now Lymany) and can be regarded as an isolectotype. Its label also contains a brief description by Andrzejowski: "involucr. ovatis enerviis ciliatis apice subsphacelatis, bracteis copiosis, linearilanceolatis elongatis. ad Hyp. infer. prope Kislakowka".

Another specimen [three plant fragments that were originally in the subfolder labeled as "Sen. praealtus $\beta$ Borysthenicus"; now mounted on two sheets, KW001002881 (sheet 1, Fig. E3, Electronic Supplement) and KW001002883 (sheet 2, Fig. E4, Electronic Supplement)], also contains a description and geographical information on two separate labels: (Label 1) "Prope Kiczkas et [text probably added later, in darker ink - S.M.] ad Cataractas Borysthenis 1823"; (Label 2) "Sen. praealtus $\beta$ Borysthenicus DC. [later identification added in darker ink at the top of the label S.M.] Senecio borysthenicus Nobis. involucr. lato-ovatis acutiusculis 3nerviis carinatis apice sphacelatis, bracteis paucis lanceolatis brevibus, radiis calathidi longioribus". As we commented above, "Kiczkas" was the local name of the German colony Cortitz Einlage, now within the city of Zaporizhzhya.

Thus the Turczaninow and Besser historical collections at $\mathrm{KW}$ contain several original specimens, 


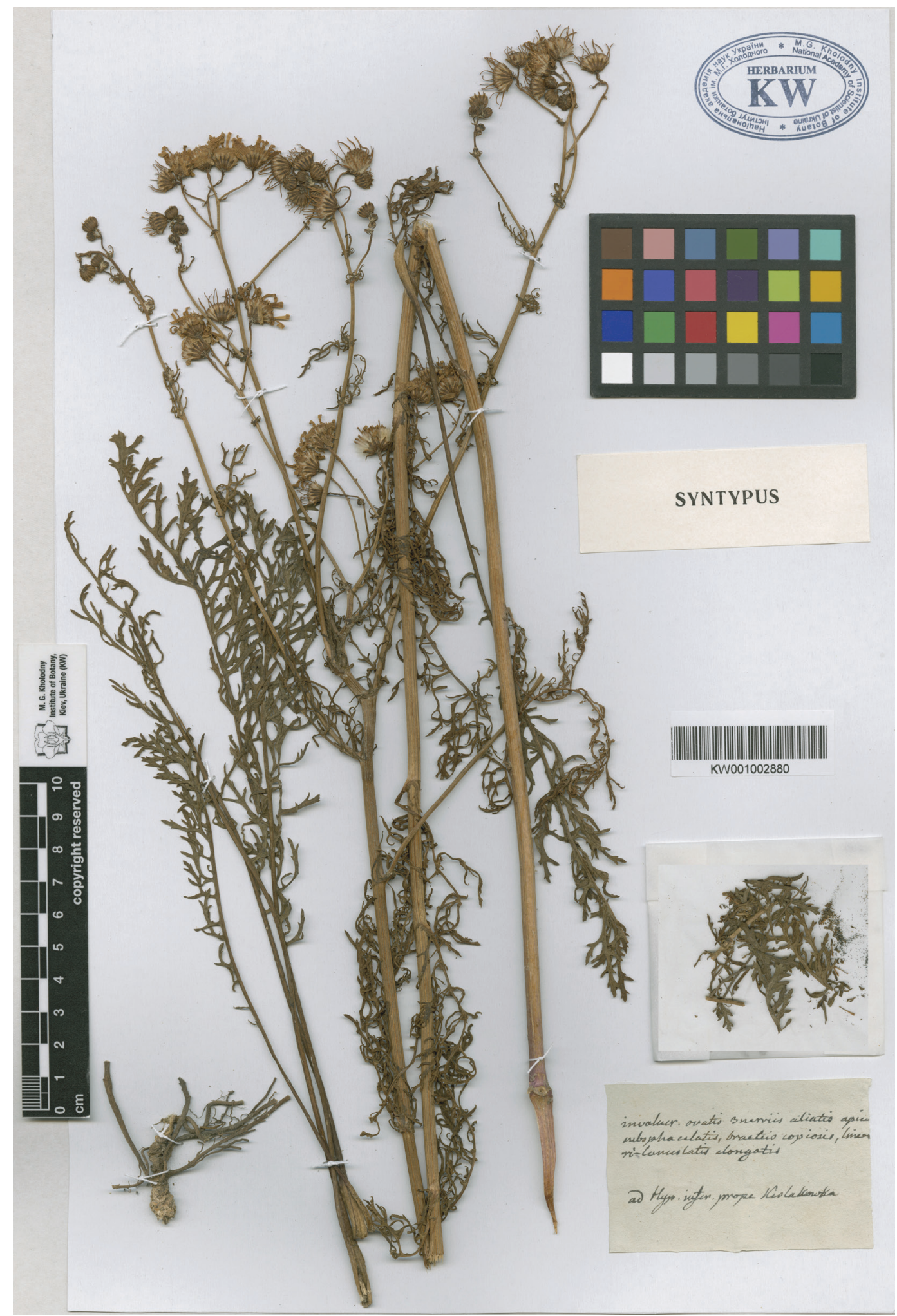

Figure 2: Isolectotype of Jacobaea borysthenica (Senecio praealtus var. borysthenicus, S. borysthenicus) from the Besser historical herbarium at KW (KW001002876) 
including two isolectotypes (KW001002876 and KW001002880, Fig. 1 and Fig. 2, respectively) collected by Andrzejowski in or near Lymany village (formerly Kyslyakivka, Kherson Governorate) in Vitovs'ky District of Mykolayiv Region. These specimens from KW, in addition to the three specimens from the de Candolle Herbarium (G-DC, see Catalogue des herbiers de Genève (CHG), 2019-onward; Mosyakin et al., 2019), provide sufficient information for establishing the precise morphology-based identity of Jacobaea borysthenica.

\section{Andrzejowski's treatment of Senecio in $\mathbf{1 8 6 2}$}

In his Continuatio Enumerationis Plantarum... Andrzejowski (1862: 103) listed the taxa of Senecio (sensu lato) occurring in the former Podolian Governorate and adjacent areas. Since that publication is rare and not available online, we provide here the text fragment from that treatment relevant to the taxa discussed in our article.

"3. Jacobæa L. vulgaris, Julio.

$\beta$. borysthenicus, orgyalis florib. minoribus. Kiew.

$\gamma$. lanatus, caulis et folia praecipue subtus incanolanata, ad Tyram.

$\delta$. grandiflorus, 1-3pedalis, radiis involucro duplo longioribus, corymbis fastigiatis, virens, in nemorosis Podoliæ frequens.

4. divaricatus A. caulibus patenti ramosis, fastigiatis cano floccosis, foliis pinnati-sectis, segmentis linearibus, obtusis, margine revolutis, infimis sublyratis utrinque viridibus; cal. squamis concoloribus, radiis longitudine calycis Nob. Videtur biennis, flores S. Jacobeæ, caules ramosissimi, ramis patentissimis. Habitus totius plantæ singularis, nullum e Senecionibus refert. In arenosis a Sawran ad Nicolaèf in arenosis hypanicis frequens, ad Cataractas Borysthenis prope Cortitz Einlage quoque reperitur. Julio.

5. tenuifolius Jacq. in pratis sylvat. Podol. superioris, Julio.

6. arenarius MB. erucæfolius Enum. Bess. in campis Pod. inferioris, nec non Gub. Chers. vulgaris. Julio, Augusto".

We were unable to find any original specimens annotated as Senecio divaricatus Andrz. in the Besser memorial herbarium (where most of Andrzejowski's specimens are deposited) or in any other collection at KW. However, the description and geographical information provided by Andrzejowski leaves no doubt that this name is applicable to the taxon originally described as Senecio praealtus var. borysthenicus and now accepted as Jacobaea borysthenica. Andrzejowski's record of Senecio jacobaea var. borysthenicus from Kyiv (Kiev) is somewhat enigmatic because typical plants of Jacobaea borysthenica are unknown in the Kyiv area. Most probably that record in fact refers to alluvial plants of the $J$. vulgaris aggregate identical to or approaching $J$. andrzejowskyi, or to some other taxon of that species complex.

It is not clear why Andrzejowski decided to change the original circumscription of his Senecio borysthenicus, as initially outlined and annotated in the Besser and de Candolle herbaria. In any case, it is nomenclaturally irrelevant because the name $S$. divaricatus Andrz. is illegitimate, being a later homonym of $S$. divaricatus $\mathrm{L}$. (Linnaeus, 1753: 866).

The text by Andrzejowski (1862), in particular, his treatment of "S. tenuifolius Jacq." and "S. arenarius MB. erucifolius Enum. Bess." [meaning $S$. erucifolius sensu Besser in his Enumeratio... (Besser, 1822) - S.M.] also confirms the earlier conclusion by Mosyakin (2018 dated "2017") that the name "S. ucranicus" has never been validly published by Besser because the word "Ucranicus" was not intended as a specific epithet and the species name was not accepted by Besser. Consequently, the name $S$. ucranicus Hodálová (1999: 334 ) is legitimate and the subspecies-rank combination should be cited as $S$. hercynicus Herborg subsp. ucranicus (Hodálová) Greuter (as originally proposed in Greuter, 2003: 247).

\section{The status of Senecio podolianus Panigrahi}

There were two different versions of English translations published for several volumes of the Flora of the USSR (see Schmid, 1998, who described that as a "bibliographically Kafkaesque situation"). In his editorial note to the treatment of Senecio in the "Indian" version (which seems to be rarer in libraries than the "US version", and is not available online) of the English translation of Vol. 26, the scientific editor of that volume Panigrahi (1995: 822) introduced the name $S$. podolianus Panigrahi with the following justification, reproduced here in toto and verbatim:

"It is not clear as to why $S$. borysthenicus Andrz. ex DC. (1837), 'nom. in syn.' is treated as the correct name for this species, nor it is indicated where S. borysthenicus Andrz. was "already done", as stated under the "Note" above. The place of publication of Steven's observation is also not given. If $S$. praealtus $\beta$ borysthenicus DC. (1837) is a valid name at (?) 
varietal rank, its transfer as $S$. borysthenicus (DC.) at species rank, would render it as a later homonym of S. borysthenicus Grossh., Opred [should be "Opred.", an abbreviation of Opredelitel' - S.M.] Rast. Kavak. [sic! should be "Kavk.", from Kavkaza - S.M.]: 470 ( ) [sic! the year is missing - S.M.] (see sl. no. 10). Hence, a 'nom. nov.' has been proposed, S. podolianus Panigr., nom. nov., based on $S$. praealtus $\beta$ borysthenicus DC., Prodr. 6 (1837) 351 the name commemorating the type locality Podolia (Art. 7.3 and Art. 33.2, ICBN, 1994)".

The evidently illegitimate replacement name $S$. podolianus proposed by Panigrahi resulted from his insufficient acquaintance with botanical literature on the subject and misinterpretation of the rules of nomenclature. Grossheim (1949: 470) did not describe a new species but just cited the name " $S$. borysthenicus Andrz." that he misapplied to the Caucasian plants that were later described as S. schischkinianus Sofieva (1957: 83) [= Jacobaea schischkiniana (Sofieva) B. Nord. \& Greuter (in Greuter, Raab-Straube, 2006: 713)]; the latter species was also recently reported from Kalmykia (Sagalaev et al., 2012). However, as we noted above, before Grossheim the binomial Senecio borysthenicus was validated earlier (Czerniaëw, 1859) and used by several other authors (e. g., Gruner, 1869 dated "1868"; Taliev, 1935; Stankov, Taliev, 1949, etc.).

\section{Nomenclature of Jacobaea borysthenica}

Jacobaea borysthenica (DC.) B. Nord. \& Greuter, Willdenowia 36(2): 712. 2006.

$\equiv$ Senecio praealtus Bertol. var. $[\beta]$ borysthenicus DC., Prodr. [A.P. de Candolle] 6: 351. 1838. $\equiv S$. borysthenicus (DC.) Andrz. ex Czern., Conspect. Pl. Charc.: 32. 1859, p.p., quoad nom. $\equiv$ S. jacobaea L. var. borysthenicus (DC.) Trautv., Bull. Classe Phys.-Math. Acad. Imp. Sci. Saint-Pétersbourg 12 (21-22): 351. 1854 [reprinted in: Mélanges Biol. Bull. Phys.-Math. Acad. Imp. Sci. Saint-Pétersbourg 2(2): 131. 1855]. $\equiv S$. podolianus Panigrahi, Fl. USSR (English translation ed. G. Panigrahi) 26: 822. 1995, nom. illeg. (published as "nom. nov." for $S$. borysthenicus). $\equiv S$. jacobaea L. subsp. borysthenicus (DC.) Ciocârlan, Fl. Il. României, ed. 3: 815. 2009, nom. inval. (sine basion. Art. 41.5 of the ICN).

Type: G00471753 (see label information above; digital image available from https://www.ville-ge.ch/musinfo/ bd/cjb/chg/adetail.php?id=329614 and https://plants. jstor.org/stable/10.5555/al.ap.specimen.g00471753), lectotype, designated by Mosyakin et al. (2019).

= Senecio divaricatus Andrz., Univ. Izv. (Kiev) [vol. of 1862] No. 7: 103. 1862, nom. illeg., non L. 1753.
Type: not designated; described from several localities in southern Ukraine (see above).

Some names misapplied to Jacobaea borysthenica in the past, remaining taxonomic problems, and concluding remarks

The name "Senecio armenius" was sometimes misapplied to Jacobaea borysthenica. That invalid name was mentioned by Ledebour (1845: 634) in synonymy of Senecio praealtus, as "S. armenius. M. a Bieb. ex Besser Enum. p. 33. Nr. 1082. - Eichw. Skizze p. 148". Evidently, "S. armenius" was a misspelling of $S$. arenarius M.Bieb. ex Besser (non Thunb.). Both Besser (1822: 33) and Eichwald (1830: 148) used the name $S$. arenarius (in both cases as nomen nudum). The same misspelling is found in Montresor (1886: 386), who also cited "S. armenius" in synonymy of $S$. praealtus. In any case, the name $S$. arenarius validated in Besser (1823: 212; see Mosyakin, 2018 dated "2017") is an illegitimate later homonym of $S$. arenarius Thunb. (Prodr. Pl. Cap. 2: 158. 1800). The illegitimate name $S$. arenarius $\mathrm{M}$. Bieb. ex Besser is now considered a synonym of Jacobaea grandidentata (Ledeb.) Vasjukov [see synonymy in: Vasjukov in Raab-Straube, Raus (2015: 452) and Mosyakin et al. (2018 dated "2017": 128)].

Jacobaea borysthenica was also occasionally misidentified as Senecio erucifolius L. sensu lato. For example, Steven (1856: 388) commented on plants that he listed under"775. S. erucaefolius": "Var. $\beta$ S. tenuifolius De C. Prodr. foliorum laciniis longis tenuibus Abrotani, quam in arena mobili inter Pepecop et Aleschki legi, et circa Kertsch copiose crescere refert D'Urville, nimis a genuina diversa et propriam speciem constituere meretum". At least the plants reported by Steven from the area north of the Isthmus of Perekop ("Perecop", connecting the Crimean Peninsula to the mainland part of Ukraine) toward the Oleshky ("Aleschki") Sands (in the present-day Kherson Region, on the left bank of the lower reaches of the Dnipro) may probably refer to Jacobaea borysthenica.

At least some earlier literature records of Senecio borysthenicus (especially from northern and eastern parts of its range) may in fact refer to Jacobaea andrzejowskyi or similar forms. When describing Senecio andrzejowskyi Tzvelev (now accepted as a species of Jacobaea), Tzvelev (1986: 254-255) mentioned that it seems to be morphologically intermediate between $S$. jacobaea and $S$. borysthenicus, and further hypothesized that his new species might be of ancient hybrid origin, resulting from introgressive hybridization of northern populations of 
the psammophytic species $S$. borysthenicus with the meadow-steppe $S$. jacobaea sensu stricto.

High-resolution scanned images of the holotype (LE01053112) and isotype (LE01053113) of $S$. andrzejowskyi were kindly provided by Ivan V. Tatanov and Irina V. Sokolova (LE, see below). Judging from these images, Jacobaea andrzejowskyi is morphologically quite close to (or even identical with?) the octoploid forms of the $J$. vulgaris aggregate recently described as $J$. vulgaris subsp. pannonica Hodálová \& Mered'a [see Hodálová et al., 2015 (online before print Nov. 2014): 1538]. Both these taxa, however, evidently differ in their morphology from J. borysthenica, which should be regarded as a rather well delimited species, both morphologically and ecologically.

Ratherlarge populations of the plants morphologically corresponding to Jacobaea vulgaris subsp. pannonica were observed and collected by Sergei Mosyakin in 2017 and 2018 in meadow and meadow-steppe habitats on slopes of the valley of the Hnylyi Tikych River, and on nearby slopes of hills and ravines near the village of Snizhky, Stavyshche District, Kyiv Region, close to the border with Cherkasy Region. At present it is the easternmost known locality of that taxon, in Ukraine and in general. However, it is quite possible that this taxon is much more widespread in Eastern Europe than it has been expected before. Its relationships with other taxa of the $J$. vulgaris aggregate from Eastern Europe (reported as taxa of Senecio sensu lato: see Tzvelev 1986; Konechnaya, 1994, etc.), such as J. andrzejowskyi (see above) and J.ferganensis (Schischk.) B. Nord. \& Greuter (Senecio ferganensis Schischk.), remain insufficiently known. Comprehensive studies of the whole species aggregate of $J$. vulgaris and related taxa in Eurasia (and especially in Eastern Europe) may bring new important results complementing the studies of this plant group in Western and Central Europe (e.g., Wysk et al., 2009; Hodálova et al., 2010, 2015; Mered'a et al., 2016).

\section{Acknowledgments}

We are grateful to Laurent Gautier, Fred Stauffer, and Nicolas Fumeaux (Conservatoire et Jardin botaniques, Genève, Switzerland) for facilitating herbarium research of Sergei Mosyakin in the de Candolle collection at G in August 2017. Our sincere gratitude is due to Karol Marhold, Iva Hodálová, and Pavol Mered'a Jr. (Botanický ústav SAV/Institute of Botany, Slovak Academy of Sciences, Bratislava, Slovakia) for discussing some aspects of taxonomy of Jacobaea; to Alisa V. Shumilova and Svitlana I. Antonenko (M.G. Kholodny Institute of Botany, National Academy of Sciences of Ukraine, Kyiv, Ukraine) for providing assistance during our herbarium research at KW; to Ivan V. Tatanov and Irina V. Sokolova (V.L. Komarov Botanical Institute, Russian Academy of Sciences, St. Petersburg, Russia) for providing digital images of type specimens of Jacobaea andrzejowskyi (Senecio andrzejowskyi) and J. ferganensis (S. ferganensis) from LE; to Dmitry V. Dubovik (V.F. Kuprevich Institute of Experimental Botany, National Academy of Sciences of Belarus, Minsk, Belarus) and Valery N. Tikhomirov (Belarusian State University, Minsk, Belarus) for providing additional information and literature on the possible occurrence of Jacobaea borysthenica in Belarus, and to Mykyta M. Peregrym (currently at Eszterházy Károly University, Eger, Hungary) for providing copies of some Romanian publications. The useful comments and suggestions of reviewers are greatly appreciated.

\section{REFERENCES}

Andrienko T.L., Peregrym M.M. (eds.). 2012. Official lists of regionally rare plants of administrative territories of Ukraine (reference book). Kyiv: Alterpress, 148 pp. [Андрієнко Т.Л., Перегрим М.М. (укладачі). 2012. Офіційні переліки регіонально рідкісних рослин адміністративних територій України (довідкове видання). Київ: Альтерпрес, 148 с.].

Andrzejowski A. 1823. Rys botaniczny krain zwiedzonych $w$ podróżach pomiędzy Bohem i Dniestrem od Zbruczy aż do Morza Czarnego odbytych w latach 1814, 1816, 1818 $i$ 1822. [Ciagg 1]. Wilno [Vilnius]: Nakladem i drukiem Jósefa Zawadzkiego, typografa Imperatorskiego Uniwersytetu [J. Zawadzki], viii + 127 pp.

Andrzejowski A. 1830. Rys botaniczny krain zwiedzonych w podróżach pomiędzy Bohem a Dniestrem aż do uyścia tych rzek w morze odbytych w latach 1823 i 1824. Ciag 2. Wilno [Vilnius]: Nakladem i drukiem A. Marcinowskiego [A. Marcinowski], vii +93 ss.

Andrzejowski A. 1850. Remarques sur le terrain plutonique du Sud-Ouest de la Russie. Bulletin de la Société Impériale des Naturalistes de Moscou, 23 (part 2, No. 3): 172-222.

Andrzejowski A. 1862. Continuatio Enumerationis Plantarum sponte in Gubernio Podolico et locis adjacentibus crescentium. Universitetskie Izvestiya (Kiev), [vol. of 1862], 7: 94-142. [In Latin; alternative Russian title: Андржиевский А. 1862. Продолжение исчисления растений Подольской губернии и смежных с нею мест. Университетские известия (Киев) [том 1862 г.], 7: 94-142].

Besser W. [W.S.J.G.]. 1810. Catalogue des Plantes du Jardin Botanique de Krzemieniec en Volhynie. [Kremenets], $88 \mathrm{pp}$.

Besser V.S. [W.S.J.G.]. 1822. Enumeratio plantarum hucusque in Volhynia, Podolia, Gub. Kijoviensi, Bessarbia CisTyraica et circa Odessam collectarum, simul cum observationibus in primitias florae Galiciae Austriacae. Vilnae [Vilnius]: Typis Josephi Zawadzki universitatis typographi [J. Zawadzki], 111 pp. 
Besser W. [W.S.J.G.]. 1823. Aperçu de la géographie physique de Volhynie et de Podolie. Mémoires de la Société Impériale des Naturalistes de Moscou, 6: 185-212.

Candolle A.-P., de. 1838 (dated "1837"). Prodromus systematis naturalis regni vegetabilis, vol. 6. Parisiis [Paris]: Sumptibus Sociorum Treuttel et Würtz, 687 pp.

Catalogue des herbiers de Genève (CHG). 2019-onward. Conservatoire \& Jardin botaniques de la Ville de Genève. Available at: http://www.ville-ge.ch/musinfo/bd/cjb/chg (Accessed 19 February 2019).

Chater A.O., Walters S.M. 1976. Senecio. In: Tutin T.G., Heywood V.H., Burges N.A., Moore D.M., Valentine D.H., Walters S.M., Webb D.A. (eds.). Flora Europaea, vol. 4. Cambridge: Cambridge University Press, pp. 191-205.

Ciocârlan V. 2009. Flora ilustrată a României: Pteridophyta et Spermatophyta, $3^{\text {rd }}$ ed. Bucureşti: Editura Ceres, 1141 pp.

Ciocârlan V. 2011. Vascular flora of the Danube Delta. Analele ştiinţifice ale Universităţii "Al. I. Cuza" Iaşi, ser. IIa. Biologie vegetală , 57(1): 41-64.

Czerniaëw B.M. 1859. Conspectus plantarum circa Charcoviam et in Ucrania sponte crescentium et vulgo cultarum. Charcovia [Kharkiv]: Typis Univ., 90 pp. [In Latin, with preface in Russian and French; alternative Russian title: Черняев B.M. 1859. Конспект растений дикорастущих и разводимых в окрестностях Харькова и в Украйне. Харьков: В университетской типографии, 90 с.].

Darafeev A.M., Sushchenya L.M., Parfenav V.I. (eds.). 1993. Red Data Book of the Republic of Belarus: rare and threatened species of animals and plants. Minsk: BelEn, 560 pp. [Дарафееў, А.М., Сушчэня Л.М., Парфенаў В.I. (рэдкал.). 1993. Чырвоная кніга Рэспублікі Беларусь: рэдкія і тыя, што знаходзяциа пад пагрозай знікнення віды жывёл і раслин. Мінск: Беларуская Энцыклапедыя імя П. Броўкі, 560 с.].

Doroftei M., Oprea A., Ştefan N., Sârbu I. 2011. Vascular wild flora of Danube Delta Biosphere Reserve. Scientific Annals of the Danube Delta Institute, Tulcea - Romania, 17: $1-37$.

Eichwald E., von. 1830. Naturhistorische Skizze von Lithauen, Volhynien und Podolien in geognostisch-mineralogischer, botanischer und zoologischer Hinsicht. Wilna [Vilnius]: Joseph Zawadzki, 256 pp.

Făgăraş M., Anastasiu P., Negrean G. 2010. Rare and threatened plants in the Black Sea coastal area between Cape Midia (Romania) and Cape Kaliakra (Bulgaria). Botanica Serbica, 34(1): 37-43.

Geideman T.S. 1986. Identification manual of higher [vascular] plants of the Moldavian SSR, $3^{\text {rd }}$ ed. Kishinev [Chişinău]: Shtiintsa [Editura Ştiinţa], 639 pp. [Гейдеман Т.С. 1986. Определитель высших растений Молдавской ССР. Кишинев: Штиинца, 639 с.].

Greuter W. 2003. The Euro+Med treatment of Senecioneae and the minor Compositae tribes - generic concepts and required new names, with an addendum to Cardueae. Willdenowia, 33: 245-250.

Greuter W. 2006-onward. Compositae (pro parte majore). In: Greuter W., von Raab-Straube E. (eds.), Compositae. Euro + Med Plantbase - the information resource for Euro-
Mediterranean plant diversity. Available at: http://ww2. bgbm.org/EuroPlusMed/PTaxonDetail.asp?NameId=1 4103\&PTRefFk=7000000 (Accessed 19 February 2019 and 10 October 2019).

Greuter W., von Raab-Straube E. (eds.). 2006. Euro+Med Notulae, 2. Willdenowia, 36: 707-717.

Greuter W., von Raab-Straube E. (eds.). 2007. Euro+Med Notulae, 3 [Notulae ad floram euro-mediterraneam pertinentes 25]. Willdenowia, 37: 139-189.

Grossheim A.A. 1949. Identification manual of plants of the Caucasus. Moscow: Sovetskaya Nauka, 747 pp. [Гроссгейм А.А. 1949. Определитель растений Кавказа. Москва: Советская наука, 747 с.].

Gruner L.F. 1869 (dated "1868"). Enumeratio plantarum, quas anno 1865 ad flumina Borysthenem et Konkam Inferiorem in Rossiae australis provinciis Catherinoslaviensi et Taurica collegit Mag. L. Gruner [Part 2]. Bulletin de la Société Impériale des Naturalistes de Moscou, 41(part 2, No. 3): 406-459.

Hodálová I. 1999. Multivariate analysis of the Senecio nemorensis group (Compositae) in the Carpathians with a new species from the East Carpathians. Folia Geobotanica, 34: 321-335.

Hodálová I., Mered'a P., Jr., Vinikarová A., Grulich V., Rotreklová O. 2010. A new cytotype of Jacobaea vulgaris (Asteraceae): frequency, morphology and origin. Nordic Journal of Botany, 28(4): 413-427.

Hodálová I., Mered'a P. Jr., Kučera J., Marhold K., Kempa M., Olšavská K., Slovák M. 2015 (online before print 2014). Origin and systematic position of Jacobaea vulgaris (Asteraceae) octoploids: genetic and morphological evidence. Plant Systematics and Evolution, 301(5): 1517-1541.

Horuzhyk L.I., Sushchenya L.M., Parfenov V.I. (eds.) et al. 2005. Red Data Book of the Republic of Belarus: rare and threatened species of wild plants. Minsk: BelEn, $456 \mathrm{pp}$. [Хоружик Л.И., Сущеня В.И., Парфенов В.И. (ред.) и др. 2005. Красная книга Республики Беларусь: Редкие и находящиеся под угрозой исчезновения виды дикорастущих растений. Минск: БелЭн, 456 с.].

Iamonico D., Managlia A. 2015. Lectotypification of the Bertoloni's names in the genus Senecio L. (Asteraceae). Plant Biosystems, 149(1): 48-53.

Katina Z.F. 1987. Senecio. In: Prokudin Yu.N. (ed.). Identification manual of vascular plants of Ukraine. Kiev: Naukova Dumka, pp. 343-346. [Катина 3.Ф. 1987. Senecio. В кн.: Определитель высших растений Украины. Ред. Ю.Н. Прокудин. Киев: Наукова думка, с. 343-346].

Konechnaya G.Yu. 1994. Senecio. In: Flora Partis Europaeae URSS, vol. 7. Ed. N.N. Tzvelev. St. Petersburg: Nauka, pp. 52-63. [Конечная Г.Ю. 1994. Senecio. В кн.: Флора европейской части СССР, т. 7. Ред. Н.Н. Цвелев. Санкт-Петербург: Наука, с. 52-63].

Kucherevs'kiy V.V. 2004. Synopsis of the flora of the RightBank Steppe of the Dnipro area. Dnipropetrovs'k: Prospect Publ., 292 pp. [Кучеревський В.В. 2004. Конспект флори Правобережннго степового Придніпров'я. Дніпропетровськ: Проспект, 292 с.]. 
Ledebour C.F. 1845. Flora Rossica, sive, Enumeratio plantarum in totius Imperii Rossici provinciis Europaeis, Asiaticis et Americanis hucusque observatarum, vol. 2. Stuttgartiae [Stuttgart]: Sumptibus Librariae E. Schweizerbart, vi $+937 \mathrm{pp}$.

Linnaeus C. 1753. Species Plantarum, vols. 1-2. Holmiae [Stockholm]: Laurentius Salvius, 1200 pp.

Mered'a P., Jr., Kučera J., Marhold K., Senko D., Slovák M., Svitok M., Šingliarová B., Hodálová I. 2016. Ecological niche differentiation between tetra- and octoploids of Jacobaea vulgaris. Preslia (Praha), 88: 113-136.

Miller P. 1754. The Gardeners Dictionary: containing the methods of cultivating and improving all sorts of trees, plants, and flowers, for the kitchen, fruit, and pleasure gardens, as also those which are used in medicine: with directions for the culture of vineyards, and making of wine in England: in which likewise are included the practical parts of husbandry. $4^{\text {th }}$ abridged ed., vol. 3. London: John and James Rivington [no pagination].

Minderova E.V. [with additions by Klokov M.V.]. 1962. Senecio. In: Flora of the Ukrainian SSR [Flora URSR], vol. 11. Ed. O.D. Visyulina. Series ed. D.K. Zerov. Kyiv: Academy of Sciences of the Ukrainian SSR, pp. 371-411. [Міндерова Є.В. (з доповненнями Клокова М.В.). 1962. Флора Української РСР, т. 11. Ред. Д.К. Зеров (гол. ред. видання), О.Д. Вісюліна (ред. тому). Київ: Вид-во АН УРСР, с. 371-411].

Montresor V. 1886. Overview of plants, being parts of the flora of Governorates of the Kiev Educational Department: Kiev, Podolian, Volhynian, Chernigov, and Poltava, vol. [issue] 2. Kiev: I.N. Kushnerev \& Co., pp. 249-508. [Монтрезор В. 1886. Обозрение растений, входящих в состав флоры губерний Киевского учебного округа: Киевской, Подольской, Волынской, Черниговской и Полтавской, вып. 2. Киев: И.Н. Кушнерев и Ко., с. 249-508].

Mosyakin S.L. 2018 (dated "2017"). "Senecio ucranicus" Besser (1822) versus Senecio ucranicus Hodálová (1999) and Jacobaea borysthenica (Asteraceae): a nomenclatural clarification. Novitates Systematicae Plantarum Vascularium [Новости систематики высших растений] 48: 126-130.

Mosyakin S.L., Fedoronchuk M.M. 1999. Vascular plants of Ukraine. A nomenclatural checklist. Kiev, xxiii +345 pp. http://dx.doi.org/10.13140/2.1.2985.0409

Mosyakin S.L., Shiyan N.M., Hodálová I. 2019. Lectotypification of Senecio praealtus var. borysthenicus (Asteraceae). Candollea, 74(2): 217-221. https://doi. org/10.15553/c2019v742a10

Mosyakin S.L., Yena A.V. 2017. Jacobaea taurica (Asteraceae), the new combination for a Crimean protected species. Ukrainian Botanical Journal, 74(4): 303-309.

Negrean G. 2011. Addenda to "Flora Romaniae" volumes 1-12. Newly published plants, nomenclature, taxonomy, chorology and commentaries (Part 1). Kanitzia, 18: 89-194.

Nordenstam B. 2006. Additions to the genus Jacobaea Mill. (Compositae - Senecioneae). Compositae Newsletter, 44: 12-13.

Nordenstam B. 2007. Tribe Senecioneae. In: Kubitzki K. (ed.). The families and genera of vascular plants, vol. 8:
Flowering plants: Eudicots: Asterales. Eds J.W. Kadereit and C. Jeffrey (volume eds.). Berlin \& Heidelberg: Springer, pp. 208-241.

Nordenstam B., Pelser P.B., Kadereit J.W., Watson L.E. 2009. Senecioneae. In: Funk V.A., Susanna A., Stuessy T.F., Bayer R.J. (eds.). Systematics, Evolution and Biogeography of Compositae. Vienna: International Association for Plant Taxonomy, Institute of Botany, University of Vienna, pp. 503-521.

Onyschenko V.A. (ed.) et al. 2017. Important Plant Areas of Ukraine. Kyiv: Alterpress, 376 pp.

Ostapko V.M., Boiko G.V., Mosyakin S.L. 2010. Vascular plants of the Southeast of Ukraine. Donetsk: Knowledge Publ., 247 pp. [Остапко В.М., Бойко А.В., Мосякин С.Л. 2010. Сосудистые растения Юго-Востока Украины. Донецк: Ноулидж, 247 с.].

Panigrahi G. 1995. Editorial note [to the treatment of Senecio by B.K. Shishkin]. In: Shishkin [Schischkin] B.K., Bobrov E.G. (eds.). Flora of the USSR (Flora $S S S R)$, vol. 26. Translated by: Doon Scientific Translation Co.; Panigrahi G. (Botanical Editor of the translation). Dehra Dun, India: Bishen Singh Mahendra Pal Singh \& Koenigstein, Germany: Koeltz Scientific Books, p. 822.

Parfenov V.I., Lekavičius A.A., Kozlovskaya N.V., Vynaev G.V., Jankevičienè R.L., Balevičienè J.J., Lazdauskaitè Z.P., Lapelè M.V. 1987. Rare and endangered species of plants of Belarus and Lithuania. Minsk: Nauka i Tekhnika, 352 pp. [Парфенов В.И., Лякавичюс А.А., Козловская Н.В., Вынаев Г.В., Янкавичене Р.Л., Балявичене Ю.Ю., Лаздаускайте Ж.П., Лапеле М.В. Редкие и исчезающие виды растений Белоруссии и Литвы. Минск: Наука и техника, 352 с.].

Pelser P.B., Gravendeel B., van der Meijden R. 2002. Tackling speciose genera: species composition and phylogenetic position of Senecio sect. Jacobaea (Asteraceae) based on plastid and nrDNA sequences. American Journal of Botany, 89: 929-939.

Pelser P.B., Kennedy A.H., Tepe E.J., Shidler J.B., Nordenstam B., Kadereit J.W., Watson L.E. 2010. Patterns and causes of incongruence between plastid and nuclear Senecioneae (Asteraceae) phylogenies. American Journal of Botany, 97: 856-873.

Pelser P.B., Nordenstam B., Kadereit J.W., Watson L.E. 2007. An ITS phylogeny of tribe Senecioneae (Asteraceae) and a new delimitation of Senecio L. Taxon, 56: 1077-1104.

Pelser P.B., van den Hof C., Gravendeel B., van der Meijden R. 2004. The systematic value of morphological characters in Senecio sect. Jacobaea (Asteraceae) as compared to DNA sequences. Systematic Botany, 29(3): 790-805.

Pelser P.B., Veldkamp J.-F., van der Meijden R. 2006. New combinations in Jacobaea Mill. (Asteraceae Senecioneae). Compositae Newsletter, 44: 1-11.

POWO. 2019-onward. Plants of the World Online. Facilitated by the Royal Botanic Gardens, Kew. Available at: http://www.plantsoftheworldonline.org (Accessed 19 February 2019 and 10 October 2019). 
Popescu A. 1972. O specie nouă pentru flora României Senecio borysthenicus Andrz. Acta Horti Botanici Bucurestiensis [Vol. of 1970-1971]: 589-592.

Popescu A. 1973. Considerații asupra speciilor de Senecio jacobea L. din Secția Jacobaei (Thunb.) Dumort. Studii şi Cercetări de Biologie, ser. Botanică, 25(4): 287-299.

Privalova L.A. 1969. Senecio. In: Wulff E.V. Flora Taurica, vol. 3, fasc. 3. Jalta [Yalta]: 225-231. [Привалова Л.А. 1969. Senecio. В кн.: Вульф Е.В. Флора Крыма, т. 3, вып. 3. Ялта, с. 225-231].

Raab-Straube E. von, Raus Th. (eds.). 2015. Euro+Med-Checklist Notulae, 5 [Notulae ad floram euro-mediterraneam pertinentes 34]. Willdenowia, 45: 449-464.

Rogowicz [Rogovich] A.S. 1869. Overview of seed plants and higher spore-bearing plants, being parts of the flora of Governorates of the Kiev Educational Department: Volhynian, Podolian, Kiev, Chernigov, and Poltava. Kiev: [Printed at St. Vladimir University of Kiev], 308 pp. [Рогович А.С. 1869. Обозрение семенных и высших споровых растений, входящих в состав флоры губерний Киевского учебного округа: Волынской, Подольской, Киевской, Черниговской и Полтавской. Киев: В университетской типографии [Университета Св. Владимира], 308 pp.]. [Bound edition; originally published in parts in: Universitetskie Izvestiya (Kiev) / Университетские известия (Киев), 1868, Nos. 4-9; 1869, Nos. 2-7].

Sagalaev V.A., Baktasheva N.M., Bochkin V.D., Zenkina T.E. 2012. Floristic findings in the Republic of Kalmykia and Astrakhan Region. Vestnik Volgogradskogo gosudarstvennogo universiteta. Series 11: Natural Sciences [volume of 2012], 1(3): 18-22. [Сагалаев В.А., Бакташева Н.М., Бочкин В.Д., Зенкина Т.Е. 2012. Флористические находки в Республике Калмыкии и Астраханской области. Вестник Волгоградского государственного университета. Серия 11. Естественные науки, 1(3): 18-22].

Schischkin [Shishkin] B.K. 1961. Senecio. In: Flora URSS, vol. 26. Eds B.K. Schischkin, E.G. Bobrov. Moscow; Leningrad: Academy of Sciences of the USSR Publ., pp. 699-788. [Шишкин Б.К. 1961. Senecio. В кн.: Флора СССР, т. 26. Ред. Б.К. Шишкин, Е.Г. Бобров. Москва; Ленинград: Изд-во АН СССР, с. 699-788].

Schischkin [Shishkin] B.K. 2000. Senecio. In: Flora of the USSR, vol. 26. Eds B.K. Schischkin, E.G. Bobrov (Eds. [of the translation]: S.G. Shetler, E. Unumb). Washington, D.C.: Smithsonian Institution Libraries \& New Delhi: Amerind Publishing Co. Pvt. Ltd., pp. 666752. [English translation of Schischkin, 1961].

Schmalhausen I.F. 1886. Flora of South-Western Russia, or Governorates of Kiev, Volhynia, Podolia, Poltava, Chernigov and adjacent areas. Kiev: O.V. Kulzhenko Publ., xlviii +783 pp. [Шмальгаузен И.Ф. 1886. Флора Юго-Западной России, т.е. губерний: Киевской, Волынской, Подольской, Полтавской, Черниговской и смежных местностей. Киев: О.В. Кульженко, xlviii + 783 pp.].

Schmalhausen I.F. 1897. Flora of Middle and Southern Russia, Crime and the North Caucasus, vol. 2. Kiev: I.N. Kushnerev \& Co., xvi + 752 рр. [Шмальгаузен И.Ф. 1897.
Флора Средней и Южной России, Крыма и Северного Кавказа, т. 2. Киев: И.Н. Кушнерев и Ко., хvi + 752 pp.]

Schmid R. 1998. A bibliographically Kafkaesque situation [review of: two translations of the Flora of the USSR (Flora SSSR), vol. 22]. Taxon, 47(3): 788-790.

Shapoval V.V. 2012. The flora of vascular plants of the Askania Steppe. Armyansk: FOP Andreev O.V., 195 pp. [Шаповал В.В. Флора судинних рослин асканійського степу. Армянськ: ФОП Андреев О.В., 195 с.].

Shishkin B.K. 1995. Senecio. In: Flora of the U.S.S.R. (Flora SSSR), vol. 26. Eds B.K. Shishkin, E.G. Bobrov. Translated by: Doon Scientific Translation Co.; Panigrahi, G. (Botanical Editor [of the translation]). Dehra Dun, India: Bishen Singh Mahendra Pal Singh \& Koenigstein, Germany: Koeltz Scientific Books, pp. 801-908. [English translation of Schischkin, 1961].

Shiyan N.M., Mosyakin S.L., Fedoronchuk M.M. 2013. Typification of taxa of the family Asteraceae in the flora of Ukraine: genera Scorzonera L., Senecio L., Serratula L., Solidago L., Sonchus L. Ukrainian Botanical Journal, 70(1): 42-44 [Шиян Н.М., Мосякін С.Л., Федорончук М.М. 2013. Типифікація таксонів родини Asteraceae флори України: роди Scorzonera L., Senecio L., Serratula L., Solidago L., Sonchus L. Украӥнський ботанічний журнал, 70(1): 42-44]. https://doi. org/10.15407/ukrbotj70.01.042

Sofieva R.M. 1957. Critical notes on the genus Senecio L. Izvestiya Akademii nauk Azerbaydzhanskoy SSR, [volume of 1957], 1: 83-90. [Софиева Р.М. 1957. Критические заметки о роде Senecio L. Известия АН Азербайджанской ССР, 1: 83-90].

Stankov S.S., Taliev V.I. 1949. Identification manual of higher plants of the European part of the USSR. Moscow: Sovetskaya Nauka, 1152 pp. [Станков C.С., Талиев В.И. 1949. Определитель высших растений Европейской части СССР. Москва: Советская наука, 1152 с.].

Steven C. 1856. Verzeichnis der auf der taurischen Halbinsel wildwachsenden Pflanzen (Continuatio) [Part 3]. Bulletin de la Société Impériale des Naturalistes de Moscou, 29(part 2, No. 4): 339-418.

Taliev V.I. 1935. Identification manual of higher plants of the European part of the USSR, $8^{\text {th }}$ ed., Moscow: OGIZ Sel'khozgiz, 647 рр. [Талиев В.И. 1935. Определитель высших растений Европейской части СССР. Москва: ОГИЗ СельхозГИЗ, 647 с.].

Tarasov V.V. 2012. Flora of Dnipropetrovsk and Zaporizhzhia Regions, $2^{\text {nd }}$ ed. Dnipropetrovsk: Lira Publ., 296 pp. [Taрасов В.В. 2012. Флора Дніпропетровської $і$ Запорізької областей. 2-ге вид. Дніпропетровськ: Ліра, 296 с.].

Thiers B. 2008-onward. Index Herbariorum. A global directory of public herbaria and associated staff. New York Botanical Garden's Virtual Herbarium. Available at: http:// sweetgum.nybg.org/science/ih (Accessed 16 February 2019).

Trautvetter E.R. 1854. Ueber die Seneciones des Kiewschen Gouvernements. Bulletin de la Classe Physico-Mathématique de l'Académie Impériale des Sciences de Saint-Pétersbourg, 12(21-22): 350-352.

Trautvetter E.R. 1855. Ueber die Seneciones des Kiewschen Gouvernements. Mélanges Biologiques tirés du Bulle- 
tin Physico-Mathématique de l'Académie Impériale des Sciences de Saint-Pétersbourg, 2(2): 129-133. [Reprinted from Trautvetter, 1854].

Tretyakov D.I. 1999. Senecio. In: Identification manual of higher [vascular] plants of Belarus. Ed. V.I. Parfenov. Minsk: Design PRO, pp. 288-290. [Третьяков Д.И. 1999. Senесіо. В кн.: Определитель высших растений Беларуси. Ред. В.И. Парфенов. Минск: Дизайн ПРО, c. 288-290].

Turland N.J., Wiersema J.H., Barrie F.R., Greuter W., Hawksworth D.L., Herendeen P.S., Knapp S., Kusber W.-H., Li D.-Z., Marhold K., May T.W., McNeill J., Monro A.M., Prado J., Price M.J., Smith G.F. 2018. International Code of Nomenclature for algae, fungi, and plants (Shenzhen Code) adopted by the Nineteenth International Botanical Congress Shenzhen, China, July 2017. Regnum Vegetabile, 159: i-xxxviii + 1-254. https://doi.org/10.12705/Code.2018
Tzvelev N.N. 1986. De plantarum speciebus nonnulis pro parte Europaea URSS novis et raris. Novitates Systematicae Plantarum Vascularium, 23: 254-263. [Цвелев Н.Н. 1986. О некоторых новых и редких для Европейской части СССР видах растений. Новости систематики высших растений, 23: 254-263].

Verloove F., Lambinon J. 2011. The non-native vascular flora of Belgium: new combinations and a new variety. New Journal of Botany, 1(1): 38-42.

Wysk R., Nordenstam B., Kadereit J.W., Westberg E. 2009. The identity and geographical distribution of Jacobaea vulgaris subsp. gotlandica, supposedly endemic of Gotland and Öland (Sweden) - the importance of multiple intraspecific samples. Taxon, 58: 1133-1140.

Yena A.V. 2012. Spontaneous flora of the Crimean Peninsula. Simferopol: N. Orianda Publ., 232 pp. [Ена A.B. 2012. Природная флора Крымского полуострова. Симферополь: Н. Оріанда, 232 с.].

Recommended for publication by F. Verloove 
https://doi.org/10.15407/ukrbotj76.06.486

\title{
Мікроморфологічні особливості грибів роду Ganoderma (Ganodermataceae) в культурі
}

\author{
Данило О. БОРОМЕНСЬКИЙ, Ніна А. БІСЬКО \\ Інститут ботаніки ім. М.Г. Холодного НАН України \\ вул. Терещенківська 2, Київ 01004, Україна \\ danylo.boromenskyi@gmail.com
}

\section{Boromenskyi D.O., Bisko N.A. 2019. Micromorphological features of species of Ganoderma (Ganodermataceae) in pure culture. Ukrainian Botanical Journal, 76(6): 486-492.}

M.G. Kholodny Institute of Botany, National Academy of Sciences of Ukraine

2 Tereshchenkivska Str., Kyiv 01004, Ukraine

\begin{abstract}
Mycelial microstructures of taxa of the genus Ganoderma from the IBK Culture Collection of Mushrooms at the M.G. Kholodny Institute of Botany NASU were investigated by light microscopy and scanning electron microscopy. In total, seven strains of the following five species were studied: $G$. carnosum, $G$. resinaceum, $G$. sinense, G. tsugae, and $G$. oregonense. Mycelium of all these species consists of thin-walled septate hyphae of different size. Characteristic microstructures for vegetative mycelia were observed: clamp connections, swollen hyphae, mycelial pellicle, mycelial cords, staghorn (coralloid) hyphae, and chlamydospores. For $G$. carnosum the following mycelial microstructures were found: single clamp connections with or without anastomoses, double clamp connections with anastomoses and rarely swollen hyphae; for $G$. resinaceum and $G$. sinense - single clamp connections, large number of staghorn hyphae, sometimes with perforations; in addition, for $G$. resinaceum ellipsoid chlamydospores with smooth surface were observed. Mycelium of $G$. tsugae was found to have two kinds of clamp connections, single clamps with or without anastomoses while in mycelium of $G$. oregonense single clamp connections and occasionally swollen hyphae were seen. Double clamp connections and those with anastomoses were noticed for the first time in vegetative mycelium of G. carnosum, as well as staghorn hyphae - in the mycelia of G. sinense and G. carnosum.
\end{abstract}

Keywords: Ganoderma, mycelium, microstructures, macromycetes, scanning electron microscopy, pure culture

Submitted 06 March 2019. Published 29 December 2019

Бороменський Д.О. Бісько Н.А. 2019. Мікроморфологічні особливості грибів роду Ganoderma (Ganodermataceae) в культурі. Український ботанічний журнал, 76(6): 486-492.

Реферат. Досліджено мікроструктури вегетативного міцелію грибів роду Ganoderma з Колекції культур шапинкових грибів (IBК) Інституту ботаніки ім. М.Г. Холодного НАН України за допомогою світлової та електронної сканувальної мікроскопії. Для дослідження було відібрано 7 штамів 5 видів: G. carnosum, G. resinaceum, G. sinense, G. tsugae, i $G$. oregonense. Міцелій всіх зразків складався з тонкостінних, септованих, розгалужених гіф різних розмірів. Описані основні типи будови та мікроструктури вегетативного міцелію цих грибів, а саме: пряжки, потовщення гіф, міцеліальна плівка, міцеліальні тяжі, коралоподібні гіфи, хламідоспори. Встановлено, що для міцелію G. carnosum характерні поодинокі пряжки з анастомозами або без них, подвійні пряжки з анастомозами, деколи потовщення гіф; для міцелію $G$. resinaceum та $G$. sinense - поодинокі пряжки, велика кількість коралоподібних гіф, інколи з перфораціями; також для $G$. resinaceum характерні еліпсоїдні хламідоспори з гладенькою поверхнею; для міцелію G. tsugae - два види пряжок: поодинокі з анастомозами та без них; для міцелію G. oregonense - поодинокі пряжки та потовщення гіф (траплялись досить рідко). Для вегетативного міцелію G. carnosum подвійні пряжки з анастомозами описані вперше. Також нами вперше виявлено коралоподібні гіфи міцелію G. sinense та G. carnosum.

Ключові слова: Ganoderma, макроміцети, мікроструктури, міцелій, сканувальна електронна мікроскопія, чиста культура

(C) 2019 D.O. Boromenskyi, N.A. Bisko. Published by the M.G. Kholodny Institute of Botany, NAS of Ukraine. This is an open access article under the terms of the Creative Commons Attribution License (http://creativecommons.org/licenses/by/4.0/), which permits use, distribution, and reproduction in any medium, provided the original work is properly cited 


\section{Вступ}

Лікарські властивості грибів роду Ganoderma P.Karst. відомі в Китаї та інших країнах ПівденноСхідної Азії тисячі років (Wasser, 2010). Відкриття антибіотиків у другій половині XX століття та розробка методів культивування мікроорганізмів дали чималий поштовх для інтенсивного та детального вивчення біологічно активних сполук грибів, а також створення лікарських препаратів на їхній основі. Основним матеріалом для досліджень були гриби, які використовуються в народній медицині, в т. ч. види роду Ganoderma (Buchalo et al., 2011). Встановлено, що вони містять численні біологічно активні сполуки - полісахариди різного складу, стероїдні компоненти, тритерпени, ганодерові кислоти тощо (Wasser, 2010; Buchalo et al., 2011). Ці речовини проявляють протипухлинні, імуномоделюючі, цитотоксичні, антидіабетичні, гепатопротекторні, антибактеріальні, антиоксидантні та інші властивості (Boh et al., 2007; Buchalo et al., 2011; Bisko et al., 2012; Li-Ying et al., 2014; Belova, 2016).

Відомо, що біологічно активні сполуки накопичуються не тільки в плодових тілах макроміцетів, а також у міцелії та культуральній рідині (Wasser, 2011). Глибинне культивування міцелію грибів дозволяє скоротити термін отримання цільового продукту та завдяки оптимізації умов вирощування проводити направлений синтез біологічно активних речовин (Bisko et al., 2012).

Однак, використання міцелію макроміцетів потребує визначення таксономічно значущих критеріїв для ідентифікації грибів у чистій культурі (Buhalo, Diduch, 2005). Використання сканувальної електронної мікроскопії (СЕМ) дає більше можливостей для вивчення мікроструктур, ніж класичний метод світлової мікроскопії (СМ). Хоча сучасні таксономічні дослідження проводяться переважно за допомогою молекулярних методів (Jargalmaa et al., 2017, Tchotet Tchoumi et al., 2019), досі існують проблеми - за влучним висловом Х. Ріхтера рід Ganoderma перебуває у стані "таксономчного хаосу" (Richter et al., 2014). Тому подальші дослідження, направлені на виявлення нових морфологічних ознак для їхнього використання у якості таксономічних критеріїв, є актуальними.

\section{Матеріали та методи}

Для дослідження було обрано штами з Колекції культур шапинкових грибів (IBK) Інституту ботаніки ім. М.Г. Холодного НАН України (Bisko et al., 2016). Культури вирощували на глюкозопептон-дріжджовому агарі (ГПДА), г/л: глюкоза 25 ; пептон - 3; дріжджовий екстракт - 3; $\mathrm{MgSO}_{4}-$ 0,$25 ; \mathrm{KH}_{2} \mathrm{PO}_{4}-1 ; \mathrm{K}_{2} \mathrm{HPO}_{4}-1$; агар-агар - 22; $\mathrm{pH}$ 6,0 у чашках Петрі.

Мікроструктури міцелію досліджували за допомогою методів СМ та СЕМ. Зразки вегетативного міцелію для СМ готували у $3 \%$ му розчині $\mathrm{NaOH}$ та досліджували за допомогою мікроскопу ІБМ 68. Зразки вегетативного міцелію для СЕМ були підготовлені за модифікованою методикою Квательбаума та Карнера (Quattelbaum, Carner, 1980). Під час інокуляції міцелію на чашки Петрі з середовищем ГПДА на різній відстані від інокулюму викладались декілька стерильних покривних скелець розміром $4 \times 4$ мм. Міцелій інкубували за температури $26 \pm 1{ }^{\circ} \mathrm{C}$. Після того, як шматочки покривних скелець повністю заросли міцелієм, вони були вирізані з поверхні живильного агаризованого середовища та перенесені на предметне скло. Далі скельце поміщали у закриту скляну чашку Петрі з парами тетраоксиду осмію на 6 год. Після закінчення терміну фіксації препарати висушували протягом 72 год у відкритій посудині. Зразки міцелію напиляли золотом та досліджували за допомогою CEM JSM-35C та Jeol JSM-6060 LA (Японія) за описаною методикою (Buchalo, Didukh, 2005). Вегетативні структури описані за класифікацією Сталперса (Stalpers, 1978).

\section{Результати та обговорення}

Наводимо результати вивчення вегетативного міцелію в чистій культурі.

\section{Ganoderma carnosum Pat.}

CEM. Міцелій складається зі септованих, тонкостінних, розгалужених гіф діаметром 1-5 мкм (рис. 1, А). Зрідка трапляються потовщення гіф. Спостерігаються пряжки трьох типів: поодинокі медальйонного типу; поодинокі з анастомозом між пряжкою та гіфою; подвійні з анастомозами між пряжками та гіфами та між собою (рис. 1, С).

CM. На міцелії при довготривалому культивуванні (60 діб) виявлені коралоподібні гіфи (рис. 1, В). 


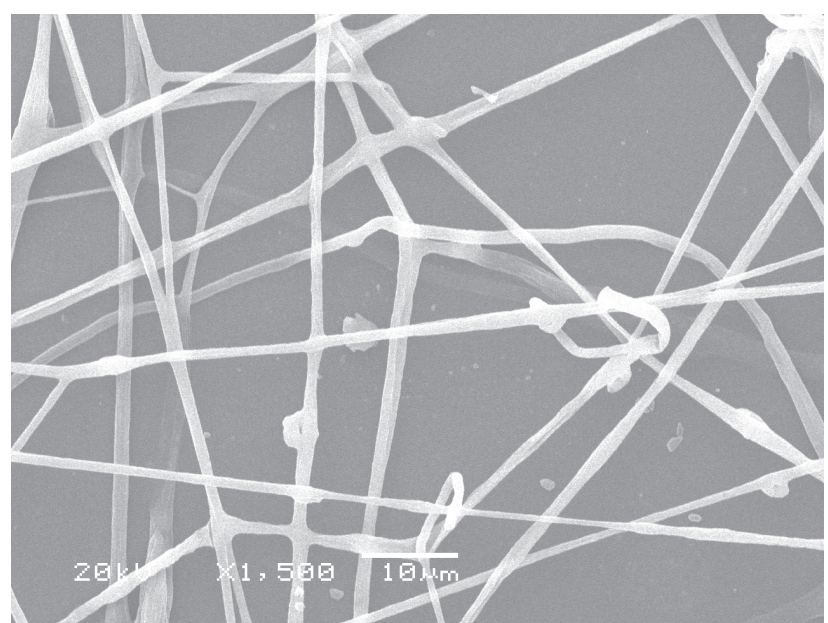

A

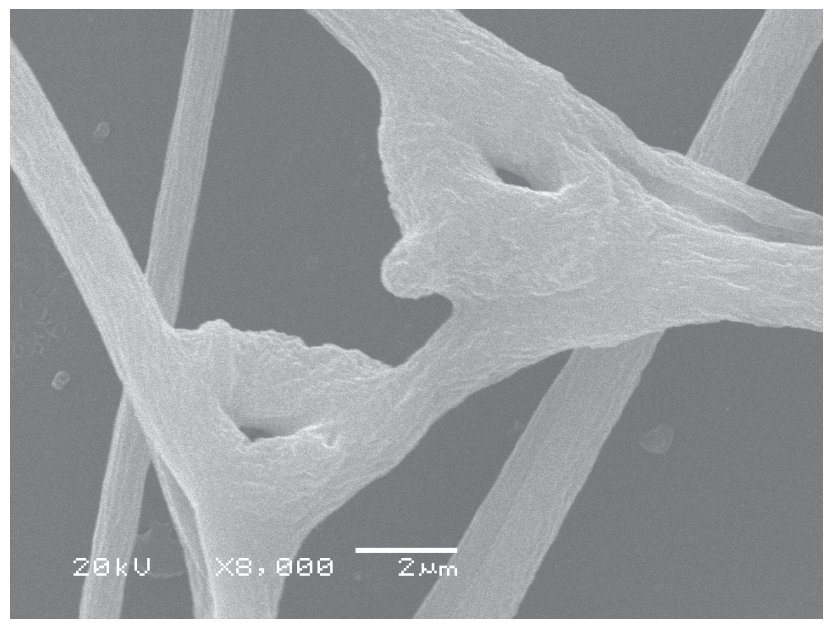

C

Досліджений зразок. Штам 2502, отримано 3 "Mycoforest type culture collection", Словаччина, 2016 p.

Примітка. Зазначимо, що поодинокі пряжки 3 анастомозом між пряжкою та гіфою для $G$. tsugae Murrill описувала раніше А.С. Бухало зі співавторами (Buchalo et al., 2009). Наявність коралоподібних гіф та подвійні пряжки з анастомозами для $G$. carnosum описані нами вперше.

\section{Ganoderma resinaceum Boud.}

CEM. Міцелій зі септованих, тонкостінних гіф, діаметром 1-3 мкм, також наявні коралоподібні гіфи у великій кількості (рис. 2, А). При більш детальному вивченні виявлено, що деякі з них містять перфорації. Характерні поодинокі пряжки медальйонного типу. Міцелій утворює еліпсоїдні хламідоспори (органи нестатевого розмноження)

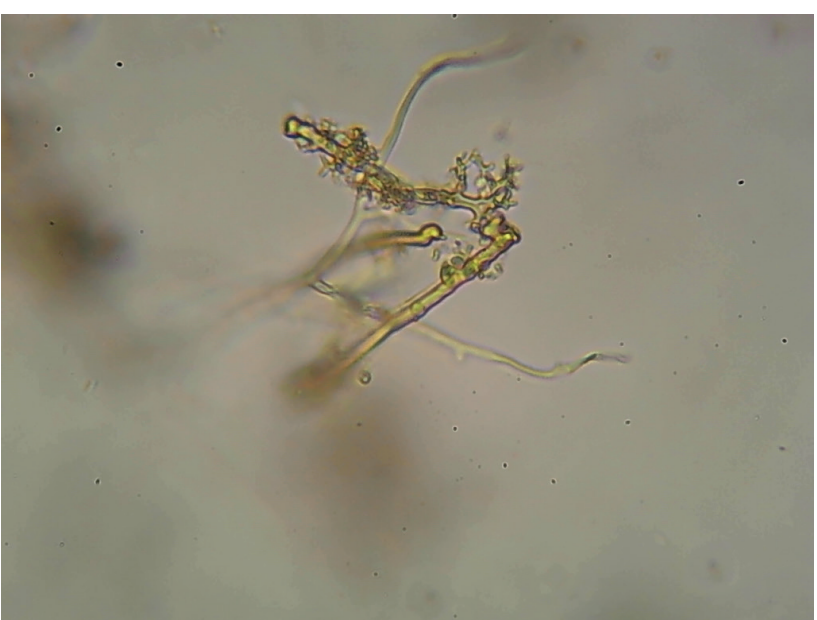

B

Рис. 1. Ganoderma carnosum 2502.

A: вегетативні гіфи з пряжками, СЕМ $(\times 1500)$; В: коралоподібні гіфи, СМ (×40); С: подвійні пряжки, СЕМ $(\times 8000)$

Fig. 1. Ganoderma carnosum 2502.

A: vegetative hyphae with clamp connections, SEM $(\times 1500)$; B: staghorn hyphae, LM $(\times 40)$; C: double clamp connections, SEM $(\times 8000)$

3 гладенькою поверхнею, які мають розміри 8-11×10-18 мкм (рис. 2, В).

Досліджені зразки. Штам 2477 виділено 3 плодового тіла, Україна, 2016 р.; штам 2503 отримано з "Mycoforest type culture collection", Словаччина, 2016 p.

Примітка. 3 літератури відомо, що утворення хламідоспор, окрім G. resinaceum, характерне ще для декількох видів роду Ganoderma, а саме: для G. adspersum (Schulzer) Donk (Balaes, Tanase, 2012), G. applanatum (Pers.) Pat. (Balaes, Tanase 2012; Tsivileva et al., 2016), G. carocalcareus Douanla-Meli (Douanla-Meli, Langer, 2009), G. colossum (Fr.) C.F. Baker (Adaskaveg, Gilbertson, 1986), G. lucidum (Curtis) P.Karst. (Adaskaveg, Gilbertson, 1986; Buchalo et al., 2009) та G. cattienensis (Tomophagus cattienensis X.T.Le \& Moncalvo) (Tsivileva et al., 2016). 


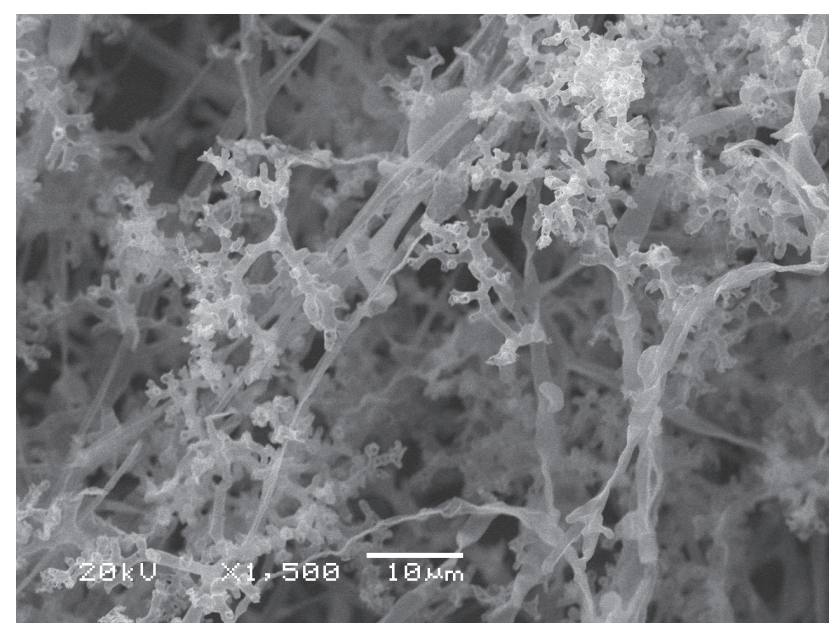

A

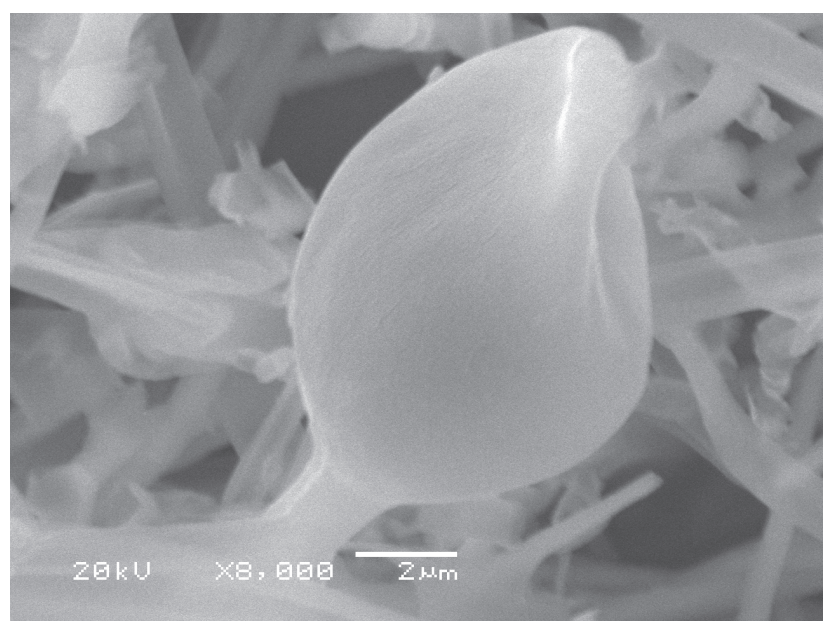

B

Рис. 2. Ganoderma resinaceum 2477. А: коралоподібні гіфи, СЕМ (×1500); В: хламідоспора, СЕМ (×8000)

Fig. 2. Ganoderma resinaceum 2477. A: staghorn hyphae, SEM $(\times 1500)$; B: chlamidospore, SEM $(\times 8000)$

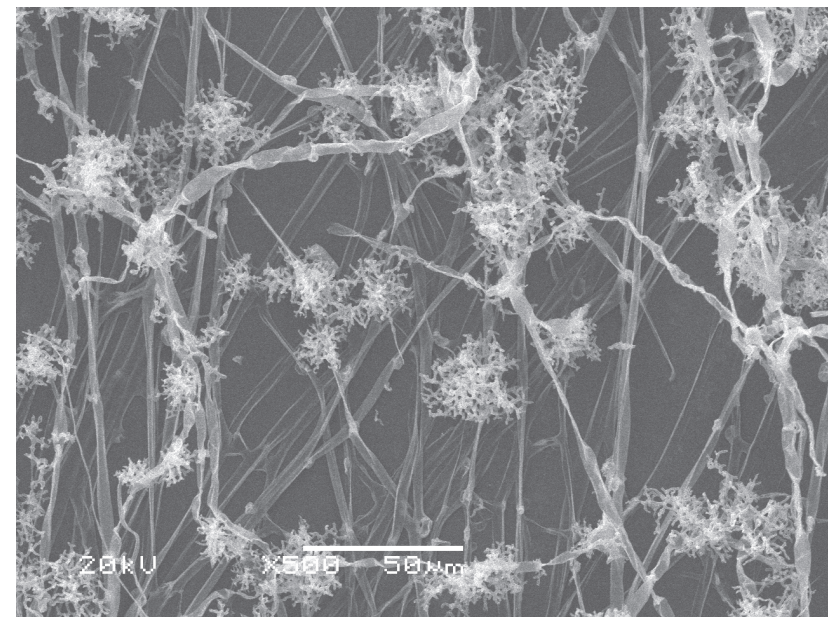

A

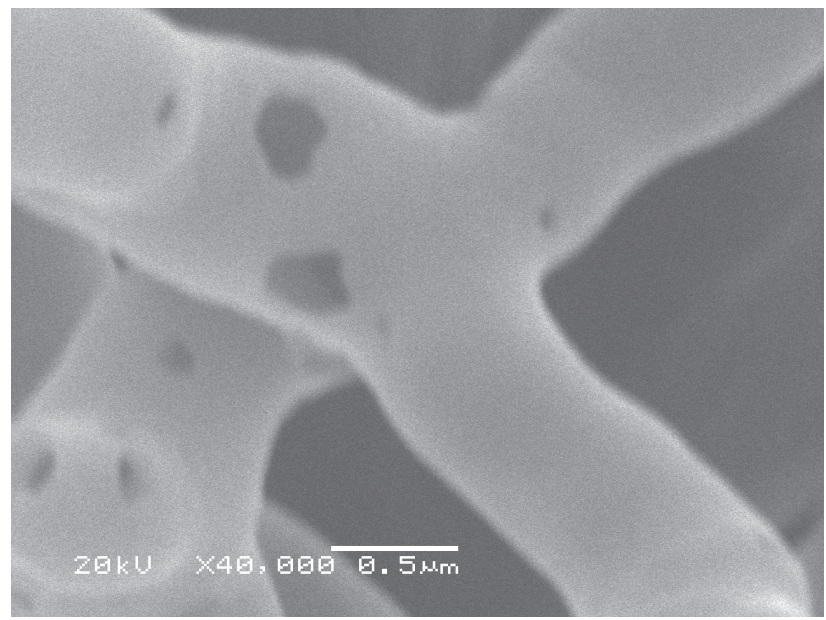

B

Рис. 3. Ganoderma sinense 2516. А: коралоподібні гіфи, СЕМ (×500); В: перфорації в коралоподібних гіфах, CEM $(\times 40000)$

Fig. 3. Ganoderma sinense 2516. A: staghorn hyphae, SEM $(\times 500)$; B: perforations in staghorn hyphae, SEM $(\times 40000)$

\section{Ganoderma sinense J.D.Zhao, L.W.Hsu \& X.Q.Zhang.}

CEM. Міцелій складається 3 тонкостінних септованих гіф, діаметром 1-5 мкм, наявні коралоподібні гіфи у великій кількості (рис. 3, А), деякі з них містять перфорації (рис. 3, В). 3 літератури відомо, що аналогічні структури утворюються на міцелії G. lucidum (Adaskaveg, Gilbertson, 1986; Buchalo et al., 2009), G. resinaceum (Adaskaveg, Gilbertson, 1986), G. meredithiae Adask. \& Gilb., G. oregonense, G. neojaponicum Imazeki (Tsvileva et al.,
2016) та G. zonatum Murrill (Adaskaveg, Gilbertson, 1989). Для даного виду характерні поодинокі пряжки медальйонного типу.

Досліджений зразок. Штам 2516 отримано 3 "Mycoforest type culture collection", Словаччина, 2016 p.

Примітка. Наявність коралоподібних гіф для вегетативного міцелію $G$. sinense описана нами вперше.

\section{Ganoderma tsugae Murrill}

Міцелій складається зі септованих, тонкостінних септованих гіф, діаметром 1-5 мкм. Для виду 


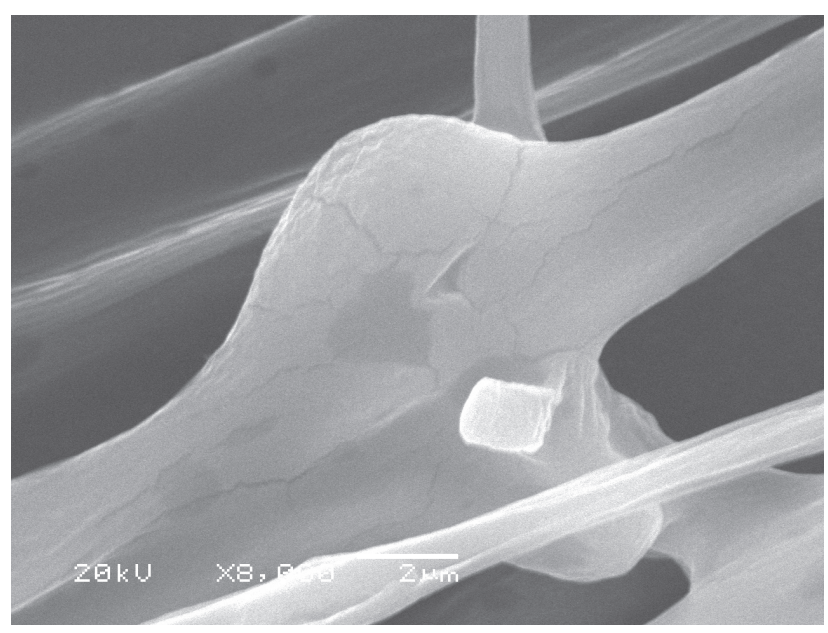

Рис. 4. Ganoderma tsugae 2566. Пряжка, СЕМ (×8000)

Fig. 4. Ganoderma tsugae 2566. Clamp connection, SEM $(\times 8000)$

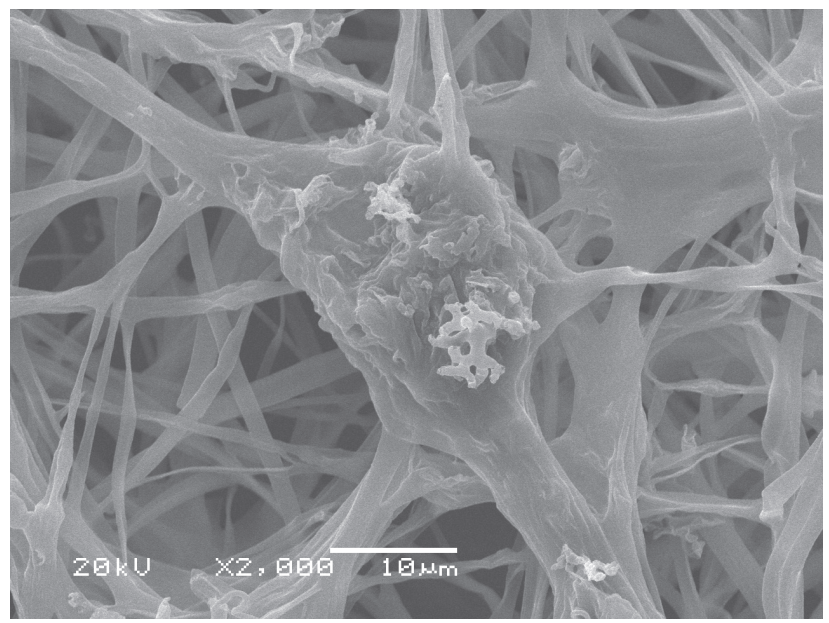

A

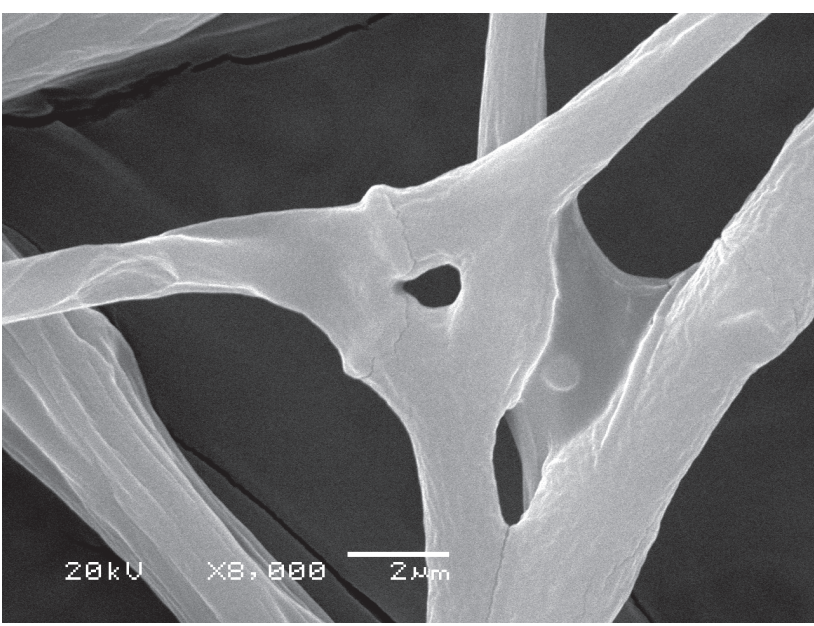

Рис. 5. Ganoderma tsugae 2024. Пряжка з анастомозами, CEM $(\times 8000)$

Fig. 5. Ganoderma tsugae 2024. Clamp connection with anastomosis, SEM $(\times 8000)$

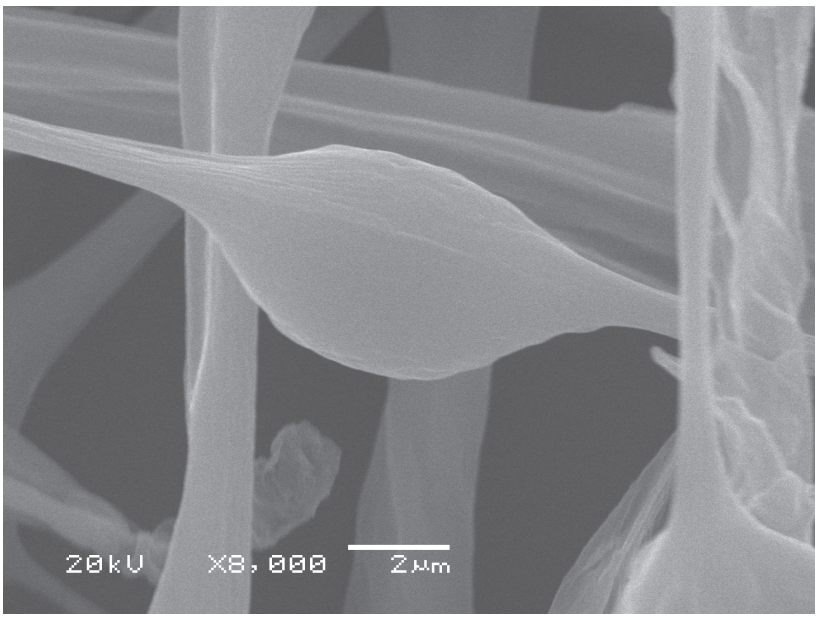

B

Рис. 6. Ganoderma oregonense 2560. А: коралоподібні структури, СЕМ (×2000); В: потовщення гіфи, СЕМ (×8000)

Fig. 6. Ganoderma oregonense 2560. A: staghorn-like hyphae, SEM $(\times 2000)$; B: hyphal thickening, SEM $(\times 8000)$

характерні пряжки двох типів: поодинокі пряжки медальйонного типу (рис. 4) та поодинокі 3 анастомозом між пряжкою та гіфою (рис. 5).

Досліджені зразки. Штам 2024 отримано 3 колекції Таврійського державного агротехнологічного університету, 2014 р.; штам 2566 отримано 3 "Mycoforest type culture collection", Словаччина, 2016 p.

\section{Ganoderma oregonense Murrill.}

CEM. Міцелій складається зі септованих, тонкостінних септованих гіф, діаметром
1-3 мкм. Для виду характерні поодинокі пряжки медальйонного типу та коралоподібні структури (рис. 6, А). Були виявлені потовщення певних ділянок гіф (пухирці на гіфах) (рис. 6, В).

Досліджений зразок. Штам 2560 отримано 3 "Mycoforest type culture collection", Словаччина, 2016 p.

Примітка. Потовщення ділянок гіф вказувались раніше авторами для різних видів роду Ganoderma: G. zonatum, $G$. meredithiae, $G$. oregonense, G. lucidum, G. tsugae (Adaskaveg, Gilbertson, 1989) та G. valesiacum sensu Pegler (G. carnosum) (Tsivileva et al., 2016). 


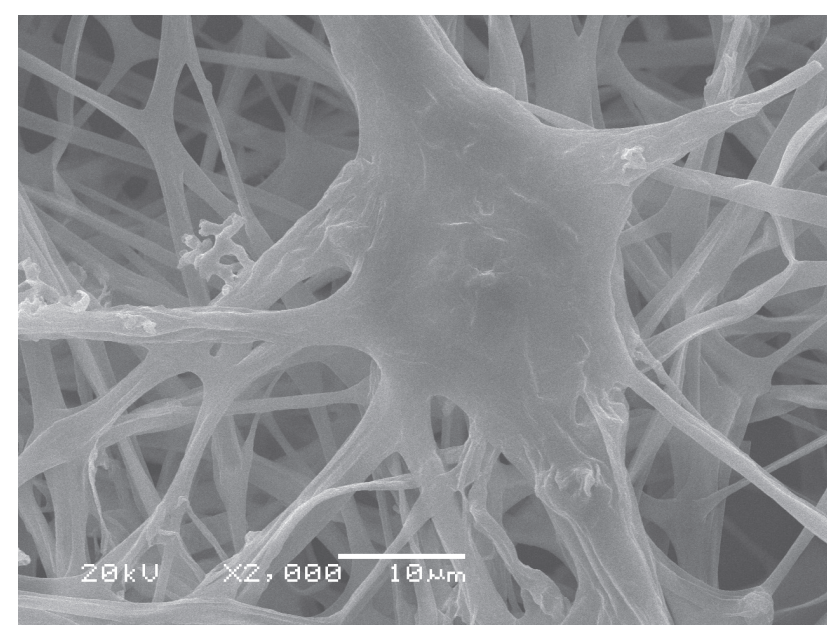

Рис. 7. Ganoderma oregonense 2560. Міцеліальна плівка, CEM $(\times 2000)$

Fig. 7. Ganoderma oregonense 2560. Mycelial pellicle, SEM $(\times 2000)$

На міцелії всіх досліджених видів роду Ganoderma виявлені структури, характерні для різних видів макроміцетів - міцеліальна плівка (рис. 7) та міцеліальні тяжі (група максимально зближених між собою гіф) (рис. 8), шо утворюються, за даними літератури, при високій концентрації поживних речовин у живильному середовищі (Zmitrovich, 2012).

Дані про виявлені нами структури вегетативного міцелію грибів роду Ganoderma підсумовані у табл. 1.

\section{Висновки}

За результатами СЕМ описані мікроструктури семи штамів п'яти видів роду Ganoderma з Колекції культур шапинкових грибів (IBK) Інституту ботаніки ім. М.Г. Холодного НАН України. Була встановлена низка нових морфологічних ознак, придатних до використання в якості таксономічних критеріїв для визначення в чистій культурі видів грибів з роду Ganoderma. Вперше виявлено наявність подвійних пряжок та пряжок 3 анастомозами на вегетативному міцелії $G$. carnosum, а також коралоподібних гіф на міцелії $G$. sinense та G. carnosum.

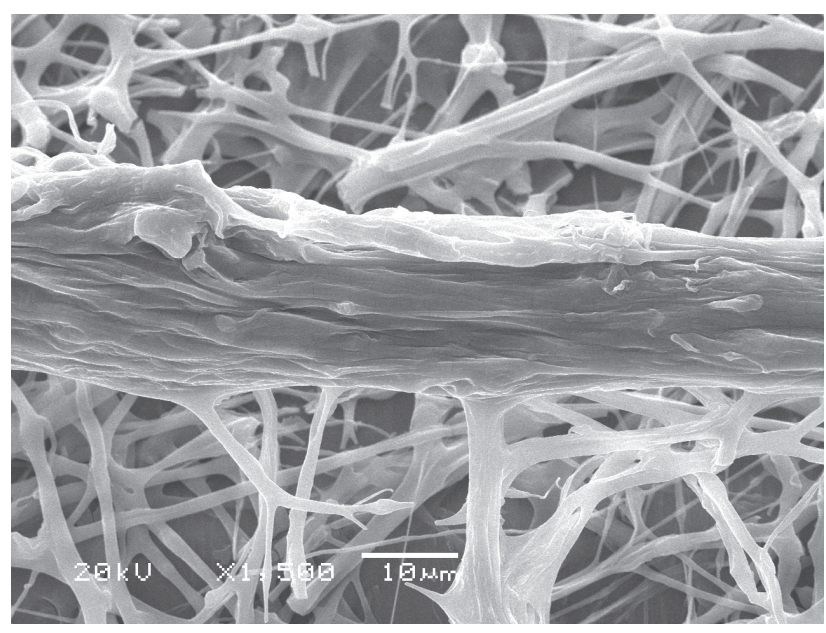

Рис. 8. Ganoderma tsugae 2566. Міцеліальні тяжі, СЕМ $(\times 1500)$

Fig. 8. Ganoderma tsugae 2566. Mycelial cords, SEM $(\times 1500)$

Таблиця 1. Мікросктруктури вегетативного міцелію грибів роду Ganoderma

Table 1. Microstructures of vegetative mycelium of the Ganoderma species

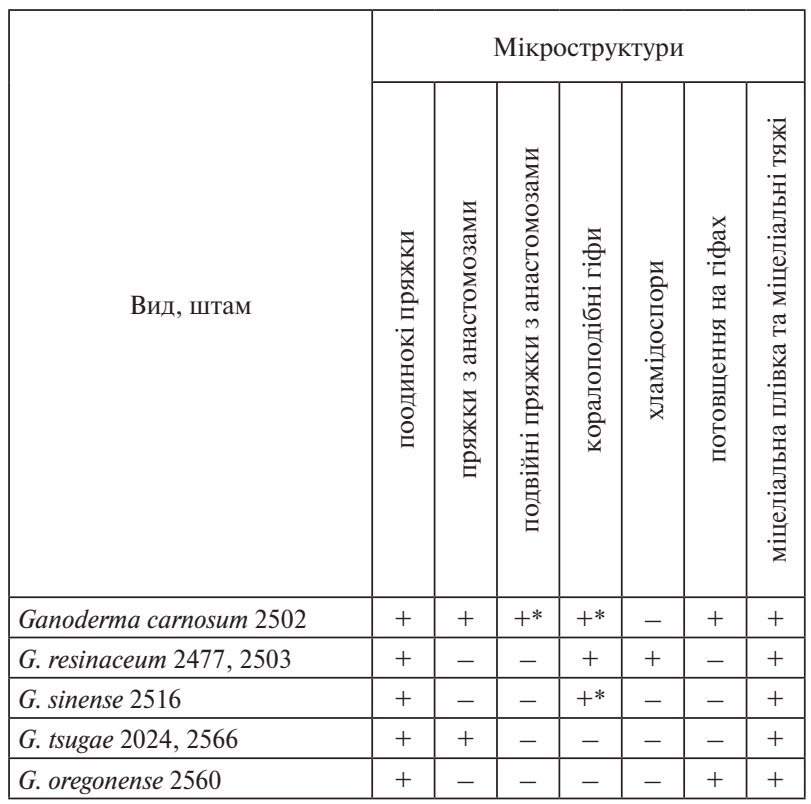

* структури, виявлені авторами вперше 


\section{СПИСОК ПОСИЛАНЬ}

Adaskaveg J.E., Gilbertson R.L. 1986. Cultural studies and genetics of sexuality of Ganoderma lucidum and $G$. tsugae in relation to the taxonomy of the G. lucidum Complex. Mycologia, 78(5): 694-705.

Adaskaveg J.E., Gilbertson R.L. 1989. Cultural studies of four North American species in the Ganoderma lucidum complex with comparisons to G. lucidum and G. tsugae. Mycological Research, 92(2): 182-191.

Balaes T., Tanase C. 2012. Description of in vitro cultures for some spontaneous lignicolous basidiomycetes species. Biologie vegetata, 58(2): 19-29.

Belova N.V. 2016. Advances in Biology \& Earth Sciences, 1(1): 111-120. [Н.В. Белова. Ланостановые тритерпеноиды и стероиды высших грибов. Advances in Biology \& Earth Sciences, 1(1): 111-120].

Bisko N.A., Babitskaya V.G., Buchalo A.S., Krupodorova T.A., Lomberg M.L., Mychaylova O.B., Puchkova T.A., Solomko E.F., Shcherba V.V. 2011. Byolohycheskye svoystva lekarstvennykh makromytsetov $v$ culture Ed. S.P. Wasser. Kiev: Alterpress, vol. 2, 459 pp. [Бисько Н.А., Бабицкая В.Г., Бухало А.С., Круподерова Т.А., Ломберг М.Л., Михайлова О.Б., Пучкова Т.А., Соломко Э.Ф., Щерба В.В. 2011. Биологические свойства лекарственных макромицетов в культуре. Под ред. С.П. Вассера. Киев: Альтерпрес, 2012, т. 2,459 c.].

Bisko N.A., Lomberg M.L., Mytropolska N.Yu., Mychaylova O.B. 2016. The IBK Mushroom Culture Collection. Kyiv: Alterpress, 120 рр. [Бісько Н.А., Ломберг М.Л., Митропольська Н.Ю., Михайлова О.Б. 2016. Колекиія культур шапинкових грибів (IВК). Київ: Альтерпрес, 120 с.].

Boh B., Berovic M., Zhang J., Zhi-Bin L. 2007. Ganoderma lucidum and its pharmaceutically active compounds. Biotechnology Annual Review, 13: 265-301. https://doi. org/10.1016/s1387-2656(07)13010-6

Buchalo A.S., Didukh M.Ya. 2005. Micromorphological characteristics of culinary-medicinal mushroom and fungi cultures. International Journal on Medicinal Mushrooms, 7(1): 249-261.

Buchalo A.S., Mykchaylova O.B., Lomberg M.L., Wasser S.P. 2009. Microstructures of vegetative mycelia of macromycetes in pure cultures. Kyiv: Alterpress, 214 pp.

Buchalo A.S., Babitskaya V.G., Bisko N.A., Wasser S.P., Dudka I.A. Mitopolskaya N.Yu., Mykchaylova O.B., Negreyko A.M., Poyedinok N.L., Solomko E.F. 2011. Byolohycheskye svoystva lekarstvennykh makromytsetov v culture. Ed. S.P. Wasser. Kiev: Alterpress, vol. 1, 212 pр. [Бухало А.С., Бабицкая В.Г., Бисько Н.А., Вассер С.П., Дудка И.А., Митропольская Н.Ю., Михайлова О.Б., Негрейко А.М., Поединок Н.Л., Соломко Э.Ф. 2011. Биологические свойства лекарственных макромицетов в культуре. Под ред. С.П. Вассера. Киев: Альтерпрес, т. 1, 212 с.].
Douanla-Meli C., Langer E. 2009. Ganoderma carocalcareus sp. nov., with crumbly-friable context parasite to saprobe on Anthocleista nobilis and its phylogenetic relationship in G. resinaceum group. Mycological Progress, 8(2): 145-155. https://doi.org/10.1007/s11557-009-0586-4

Jargalmaa S., Eimes J.A., Park M.S., Park J.Y., Oh S.-Y., Lim Y. W. 2017. Taxonomic evaluation of selected Ganoderma species and database sequence validation. PeerJ, 5: 1-16. doi:10.7717/peerj.3596

Li-Ying L., Hui C., Chao L., Hong-Qing W., Jie K., Yan L., Ruo-Yun C. 2014. Triterpenoids of Ganoderma theaecolum and their hepatoprotective activities. Fitoterapia, 98: 254-259. https://doi.org/10.1016/j.fitote.2014.08.004

Richter C., Wittstein K., Kirk P.M., Stadler M. 2014. An assessment of the taxonomy and chemotaxonomy of Ganoderma. Fungal Diversity, 71(1): 1-15. https://doi. org/10.1007/s13225-014-0313-6

Tchoumi J.M.T., Coetzee M.P.A., Rajchenberg M., Roux J. 2019. Taxonomy and species diversity of Ganoderma species in the Garden Route National Park of South Africa inferred from morphology and multilocus phylogenies. Mycologia, 18(1): 730-747. doi:10.1080/00275514.2019.1635387

Tsivileva O., Nguyen T., Vu L., Yurasov N., Chernyshova M., Petrov A., Galushka V., Markin A., Koftin O. 2016. Vietnamese Ganoderma: growth, peculiarities, and lowmolecular composition compared to European and Siberian strains. Turkish Journal of Botany, 40(3): 269-286. https://doi.org/10.3906/bot-1410-15

Quattelbaum D., Carner G.-R. 1980. A technique for preparing Beaveria spp. for scanning electron microscopy. Canadian Journal of Botany, 58: 1700-1703. https://doi. org/10.1139/b80-198

Stalpers J.A. 1978. Identification of wood-inhabiting Aphyllophorales in pure culture. Studies in Mycology, 16(1): $1-248$.

Wasser S.P. 2010. Medicinal mushrooms Science: History, Current status, Future Trends and Unsolved Problems, International Journal on Medicinal Mushrooms, 12(1): $1-16$.

Wasser S.P. 2014. Medicinal Mushroom Science: Current Perspectives, Advances, Evidences, and Challenges. Biomedical Journal, 37(6): 345-35. https://doi. org/10.4103/2319-4170.138318

Zmitrovich I.V. 2012. In: Mytselyalnyi obraz zhyzny y ekoloho-trofycheskye hruppy hrybov: Materialy VI Vserossyiskoy mykolohycheskoy shkoly-konferentsyi s mezhdunarodnym uchastyem. Moscow, pp. 1-34. [Змитрович И.В. 2012. Феноменология мицелия. В сб.: Материаллы VI Всероссийской микологической школы-конференции с международным участием "Мицелиальный образ жизни и эколого-трофические группы грибов". Москва, c. $1-34]$.

Рекомендує до друку М.М. Сухомлин 


\title{
Біологічні особливості рідкісного гриба Sparassis nemecii (Sparassidaceae, Polyporales) на рослинних субстратах в чистій культурі
}

\author{
Марія В. ПАСАЙЛЮК \\ Національний природний парк "Гуцульщина" \\ вул. Дружби 84, Косів 78600, Івано-Франківська обл., Україна \\ mariia.pasailiuk@gmail.com
}

Pasailiuk M.V. 2019. Biological peculiarities of a rare mushroom Sparassis nemecii (Sparassidaceae, Polyporales) on plant substrates in pure culture. Ukrainian Botanical Journal, 76(6): 493-498.

Hutsulshchyna National Nature Park

84 Druzhby Str., Kosiv 78600, Ivano-Frankivsk Region, Ukraine

Abstract. Mycelium growth in culture and morphological features of Sparassis nemecii 2327 on eleven multicomponent substrates were studied. The substrate components included: wheat grain, sunflower husk, pumpkin husk, peanut husk, wheat straw, conifer shavings, and plant litter from coniferous forest. The substrate components and their ratios suitable for obtaining mycelium of the fungus were selected. It was established that wheat grain is a compulsory substrate component for productive cultivation of the mycelium of $S$. nemecii. The combination of the components and mechanical properties of the substrate are also important factors for mycelium growth of $S$. nemecii. Densely packed substrates were found to be more appropriate. Substrates no. 2 (wheat grain/ conifer shavings/ sunflower husk/ wheat straw - 8/2/1/1) and no. 7 (wheat grain/ forest litter $1 / 2$ ) were the best compositions suitable for mycelium growth of $S$. nemecii under laboratory conditions. By the $25^{\text {th }}$ day of the experiment, a degree of overgrown substrate no. 2 and no. 7 was $85 \%$ and $75 \%$, respectively. Vegetative mycelium obtained on the substrate no. 2 was dense, of creamy milk color, with a small number of air hyphae. White mycelium with a large number of air hyphae was observed on other substrates, with separate components clearly visible. Under laboratory conditions we have not obtained fungal fruit bodies similar in size and weight to natural ones. Thus our further experiments will be carried out to determine optimal cultivation conditions (temperature, light, $\mathrm{pH}$, etc.) for growing fruit bodies of $S$. nemecii as well as substrate weight and its components ratio, based on the already obtained data on mycelium growth.

Keywords: cultivation, mycelium overgrowth, overgrown substrate, wheat grain

Submitted 02 January 2019. Published 29 December 2019

Пасайлюк М.В. 2019. Біологічні особливості рідкісного гриба Sparassis nemecii (Sparassidaceae, Polyporales) на рослинних субстратах в чистій культурі. Український ботанічний журнал, 76(6): 493-498.

Реферат. Досліджена специфіка росту і морфологічні особливості Sparassis петесіi 2327 на 11 композиціях рослинних субстратів різного складу, що включали: зерно пшениці, стружку хвойних порід дерев, лушпиння соняшника, гарбуза та арахісу, солому пшениці, лісову підстилку з-під дерев хвойних порід. Підібрані субстрати, компоненти та співвідношення яких придатні для отримання міцелію гриба. Встановлено, що для успішного вирощування міцелію $S$. петесіi обов'язковим компонентом субстрату є зерно пшениці. Важливими факторами також є природа складових, спосіб їхнього комбінування та механічні властивості субстрату - міцелій $S$. петесіi краще росте на субстраті, компоненти якого в силу фізичних особливостей їхньої структури розташовуються щільно. Цим критеріям відповідають субстрати № 2 (зерно пшениці/ стружка хвойних/ лушпиння соняшника/ солома пшениці - 8/2/1/1/) та № 7 (зерно пшениці/лісова підстилка - 1/2), які є найкрашими композиціями для вирощування міцелію $S$. nетесіi в лабораторних умовах. Ступінь обростання субстрату № 2 та № 7 до 25 -ї доби експерименту складав 85\% та $75 \%$ відповідно. Вегетативний міцелій $S$. петесіi 2327 , отриманий на субстраті № 2 , щільний, молочно-кремового забарвлення, з невеликою кількістю повітряних гіф. На інших субстратах спостерігали міцелій білого кольору 3 великою кількістю повітряних гіф, добре видимі окремі компоненти субстрату. В лабораторних умовах ми не отримали характерних для природних умов плодових тіл гриба, тому наступні наші експерименти, присвячені вирощуванню плодових тіл $S$. петесіi в лабораторії, будуть пов'язані із коригуванням ваги субстратів та співвідношенням їхніх компонентів і підбором оптимальних умов культивування (температура, світло, $\mathrm{pH}$, тощо) з урахуванням отриманих відомостей щодо специфіки росту міцелію гриба.

Ключові слова: зерно пшениці, культивування, обростання субстрату міцелієм

(C) 2019 M.V. Pasailiuk. Published by the M.G. Kholodny Institute of Botany, NAS of Ukraine. This is an open access article under the terms of the Creative Commons Attribution License (http://creativecommons.org/licenses/by/4.0/), which permits use, distribution, and reproduction in any medium, provided the original work is properly cited

Український ботанічний журнал, 2019, 76(6) 


\section{Вступ}

Рід Sparassis Fr. на території України представлений трьома видами: S. laminosa Fr., S. crispa (Wulfen) Fr. i $S$. nemecii Pilát \& Veselý. (Heluta, 2009; Leshan, Pakhomov, 2009; Heluta et al., 2016; Mykchaylova, 2017).

В Україні $S$. петесіi вперше був виявлений у 2009 р. неподалік м. Косів (Івано-Франківська обл.) у Національному природному парку "Гуцульщина" під Abies alba Mill. В.П. Гелютою (Heluta et al., 2016; Mykchaylova, 2017). Плодові тіла утворюються на корінні, біля основи стовбурів старих дерев Abies sp. у серпні-жовтні. Гриб є сапротрофом або інколи розглядається як паразит Abies sp. і є слабким патогеном, що спричинює буру гниль (Heluta et al., 2016).

В Україні цей вид є кандидатом на включення до Червоної книги України (Heluta et al., 2016). E зникаючим (категорія EN - Endangered) у Червоному списку грибів Чеської республіки (Holec, Beran, 2006). Наразі охорона виду здійснюється в НПП "Гуцульщина", а культура S. nетесіi 2327 зберігається в Колекції культур шапинкових грибів (IBK) Інституту ботаніки ім. М.Г. Холодного НАН України, яка є об'єктом національного надбання України та внесена в міжнародні бази даних Всесвітньої федерації колекцій культур - WDCM (http://www.wfcc. info/ccinfo/index.php/collection/by_id/1152/) (Lomberg et al., 2015; Bisko et al., 2016). Культура отримана зі спор гриба, знайденого на території НПП "Гуцульщина" в 2015 p. (Bisko et al., 2016); iii культурально-морфологічні властивості добре вивчені фахівцями Інституту ботаніки ім. М.Г. Холодного НАН України (Mykchaylova, 2017).

Проте питання підбору рослинних субстратів для вирощування міцелію $S$. петесіi задля отримання плодових тіл гриба наразі не досліджене. Гриб має харчову цінність - білий щільний м'якуш 3 приємним солодкуватим смаком і запахом та значні розміри плодового тіла. Так, знайдені екземпляри сягали 10-30 см у діаметрі й 5-15 см заввишки (Heluta et al., 2016). Зважаючи на ці характеристики, культивування виду для отримання плодових тіл $€$ комерційно перспективним. Експерименти 3 можливості відтворення виду в лабораторних умовах важливі для отримання відомостей щодо специфіки росту культури на рослинних субстратах і підбору оптимальних умов культивування для його плодоношення. Також ці результати мають значення для збереження виду.

\section{Матеріали та методи}

Об'єктом дослідження слугувала чиста культура Sparassis neтесіi 2327, отримана з Колекції культур шапинкових грибів (IBK) Інституту ботаніки ім. М.Г. Холодного НАН України.

Динаміку росту вегетативного міцелію $S$. петесіi досліджували на таких комбінаціях субстратів (співвідношення за масою):

№ 1 - зерно пшениці/стружка хвойних/лушпиння соняшника $-2 / 2 / 1$;

№ 2 - зерно пшениці/стружка хвойних/лушпиння соняшника/солома пшениці - 8/2/1/1;

№ 3 - зерно пшениці/лушпиння гарбуза/лушпиння соняшника/лушпиння арахісу $-4 / 2 / 1 / 1$;

№ 4 - стружка хвойних/лушпиння соняшника $2 / 1$;

№ 5 - стружка хвойних/лушпиння соняшника/ солома пшениці $-2 / 1 / 1$;

№ 6 - лушпиння гарбуза/лушпиння соняшника/ лушпиння арахісу $-2 / 1 / 1$;

№ 7 - зерно пшениці/лісова підстилка з-під дерев хвойних порід $-1 / 2$;

№ 8 - зерно пшениці/лісова підстилка 3-під дерев хвойних порід/стружка хвойних $-1 / 1 / 1$;

№ 9 - зерно пшениці/лісова підстилка з-під дерев хвойних порід/стружка хвойних/ солома $1 / 1 / 1 / 1$

№ 10 - зерно пшениці/лісова підстилка з-під дерев хвойних порід/солома $-1 / 1 / 1$;

№ 11 - зерно пшениці/стружка хвойних/солома $1 / 1 / 1$.

Суміш стружки дерев хвойних порід отримували шляхом стругання здорової деревини Abies alba та Pinus sylvestris L. (розміри дерев'яних часток 10 $\times 10-40 \times 2$ мм). Лушпиння соняшника, гарбуза, арахісу попередньо просушували, зерно пшениці проварювали впродовж 25-30 хв із розрахунку 10 кг зерна на 10 л води. Після просушування перемішували із гіпсом (1 кг зерна -12 г гіпсу) та крейдою (1 кг зерна - 3 г крейди).

Лісову підстилку збирали з-під дерев хвойних порід (Abies alba, Pinus sylvestris) та просушували впродовж 1 годза температури $60^{\circ} \mathrm{C}$. В експерименті використовували висушену, подрібнену до 2,55,0 см солому пшениці. 
Компоненти кожного субстрату ретельно перемішували, усі субстрати зволожували (до вологості 60\%) та розкладали в 3-літрові ємності. Кожен термостійкий пакет містив $600 \pm 15$ г зволоженого субстрату, рН 5.5 (рН вимірювали на pH-метрі марки МР-103, Тайвань). Емності з усіма варіантами субстратів автоклавували впродовж 90 хв за умов тиску 2 атм та стерильно інокулювали посівним міцелієм 25-денного віку, вирощеним на солодовому агарі з додаванням тирси ялиці за температури $26 \pm 0,1{ }^{\circ} \mathrm{C}$ та $\mathrm{pH} 5,5$. У кожну ємність вносили колонію міцелію з чашки Петрі діаметром 90 мм. Посіви інкубували за температури $26 \pm 0,1^{\circ} \mathrm{C}$ та $30 \%$ вологості. Щодня візуально контролювали та реєстрували ступінь обростання субстрату міцелієм культури. Для цього лінійкою вимірювали висоту обростання субстрату міцелієм із чотирьох взаємно перпендикулярних боків ємності. Обчислювали середні значення та визначали (у \%) висоту оброслого міцелієм субстрату. Враховуючи той факт, що в деяких випадках ріст міцелію відбувався по всьому субстрату, а гіфи інколи не були добре помітні, ми ввели поняття коефіцієнту повноти обростання субстрату. Його встановлювали, визначаючи видимі площі, повністю заповнені міцелієм (без можливості ідентифікації природи субстрату), та площі, де компоненти субстрату добре проглядалися, і ознак їхнього обростання міцелієм не було (Pasailiuk et al., 2018). Площу вимірювали, керуючись загальноприйнятими математичними методами.

Прийняли коефіцієнти повноти обростання субстрату від 0,1 до 1,0 де: 0,1 - добре видимі компоненти субстрату, поодинокі тяжі міцелію пронизують усю товщу пакету (рис. 1 А, В); 1,0 не вдається ідентифікувати компоненти субстрату, у полі зору тільки міцелій; $0,1<\mathrm{x}<1,0$, де $\mathrm{x}-$ відношення площі, повністю оброслої міцелієм до загальної площі.

Приклади оцінювання коефіцієнту повноти обростання субстрату $(0,1 ; 0,25 ; 05 ; 0,75)$ наведені на рис. 1.

Обростання субстрату визначали шляхом помноження висоти оброслого міцелієм субстрату (\%) на коефіцієнт повноти обростання субстрату.

Через 30 діб після інокуляції температуру інкубації знижували до $20^{\circ} \mathrm{C}$, вологість підвищували до $60 \%$. Всі досліди проводили у чотирьох біологічних повторностях. Статистичну обробку отриманих

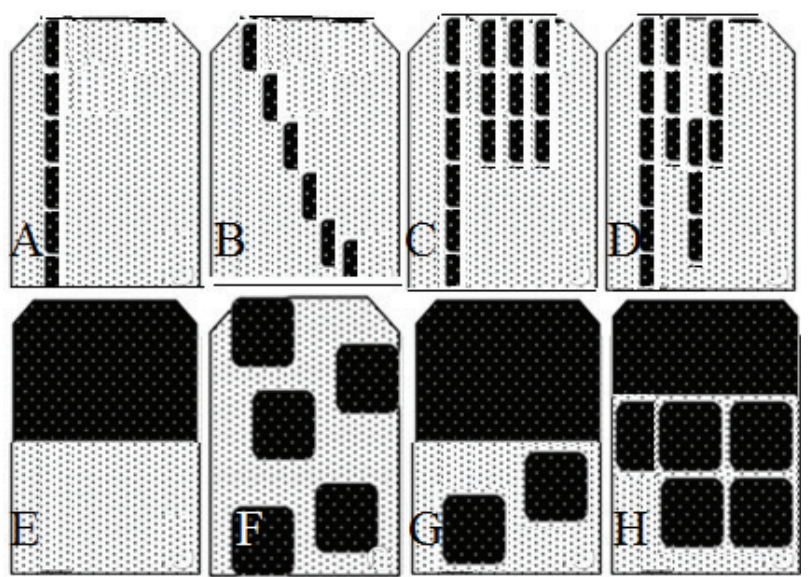

Рис. 1. Приклади розрахунку коефіцієнту повноти обростання субстрату міцелієм Sparassis nетесіi 2327. A, B: $0,1 \%$; C, D: 0,25, E, F: 0,5, G, H: 0,75

Fig. 1. Examples of calculation of the coefficient of substrate overgrowth by mycelium of Sparassis nemecii 2327. A, B: 0.1; C, D: 0.25 ; E, F: 0.5; G, H: 0.75

результатів проводили з використанням програми Statistica 8.0 (StatSoft Inc., USA).

\section{Результати та обговорення}

На основі аналізу специфіки росту $S$. петесіi 2327 на рослинних субстратах різного складу встановлено, що із апробованих субстратів найкращими комбінаціями для вирощування міцелію $S$. петесіi є субстрати № 2 та № 7, ступінь обростання яких до 25-ої доби експерименту складав $85 \%$ та $75 \%$ відповідно (рис. 2).

Використання субстратів № 8-11 виявилось менш успішним, адже міцелій заповнював їх тільки на 28-50\%, а використання субстратів № 1-6 є недоцільним.

Аналізуючи отримані результати, ми звернули увагу на те, що негативний результат мав місце у тих випадках, коли в субстраті були відсутні зерна пшениці (субстрати № 4, 5, 6). Отже, присутність цього компоненту $є$ однією 3 умов успішного вирощування міцелію $S$. петесіi. Але комбінації, використані в субстратах № 1 і № 3, виявилися непридатними для обростання міцелієм, хоча й містили зерно пшениці. Імовірною причиною цього є їхня невисока щільність.

Очевидно, важливу роль при обростанні полікомпонентних субстратів має не тільки їхня природа, але й ступінь подрібнення та ущільнення. 3 цим фактом ми вже стикалися при культивуванні 


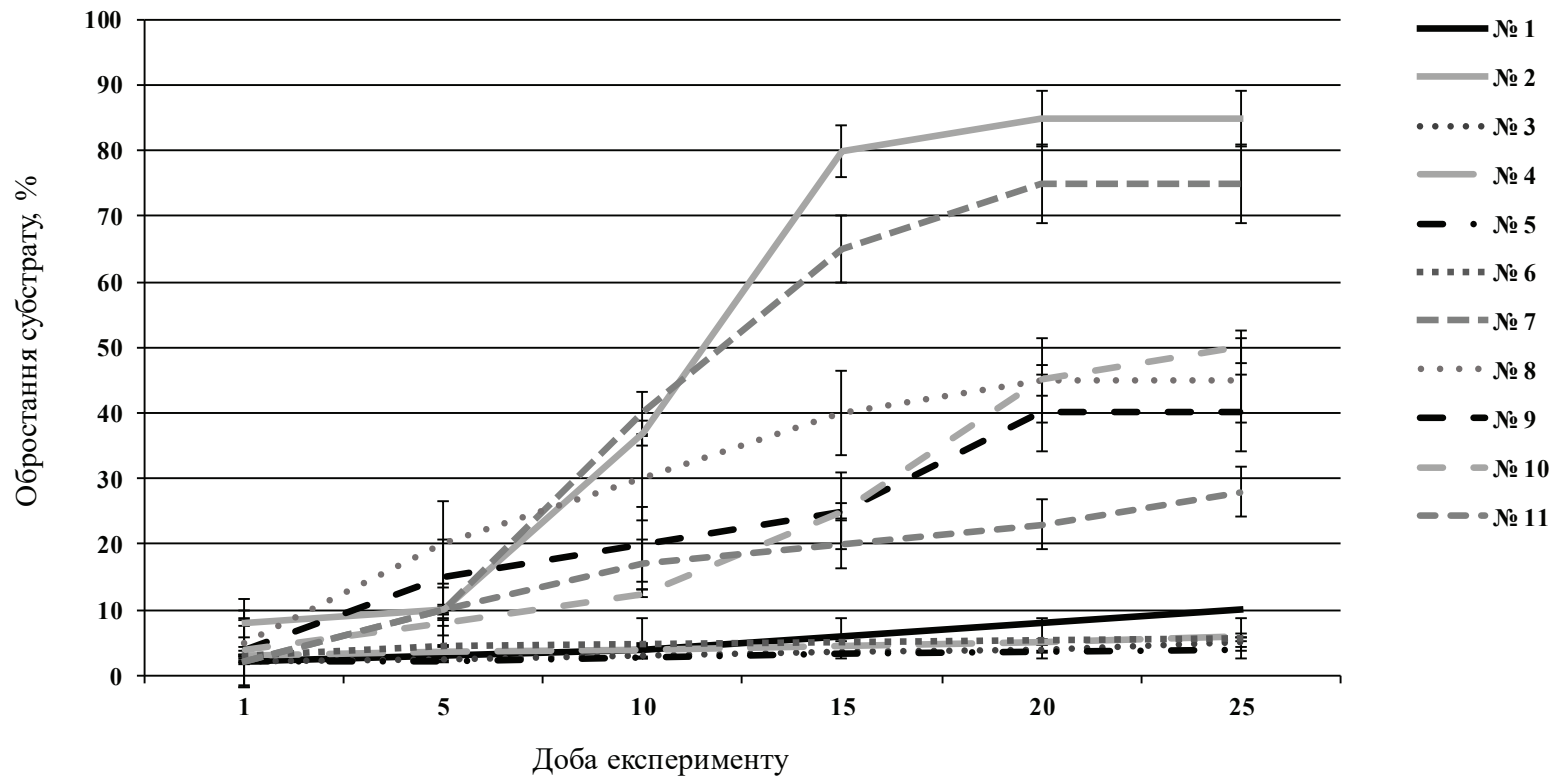

Рис. 2. Динаміка обростання міцелієм Sparassis nетесіi 2327 комбінованих досліджених субстратів № 1-11 (розшифрування див. в тексті)

Fig. 2. Dynamics of overgrowth of the combined substrates nos 1-11 by mycelium of Sparassis nemecii 2327 (see legend in the text)

Anthurus archeri (Berk.) E.Fisch., коли було показано, що механічні якості субстрату важливі для його обростання міцелієм гриба (Pasailiuk et al., 2018). У випадку із $S$. петесіi міцелій краще росте на субстраті, компоненти якого розташовуються щільно. Так, у субстраті № 2 висока щільність досягається за рахунок зерна пшениці (вміст якого досягає 75\%), у субстраті № 7 - за рахунок зерна пшениці та лісової підстилки.

Цим припущенням можна пояснити нижчі показники обростання субстратів № 8-11, в яких застосування стружки та соломи не перешкоджае міцелію $S$. петесіi обростати весь субстрат, проте зазначені компоненти залишаються не оброслими i добре помітними на 20-ту добу експерименту (рис. 3).

На субстраті № 2 ми спостерігали щільний, молочно-кремового забарвлення міцелій 3 невеликою кількістю повітряних гіф (рис. 3, А). В окремих місцях на поверхні субстрату можна було ідентифікувати солому, стружку, лушпиння соняшника. Зерно пшениці повністю обростало міцелієм, і присутність окремих зерен не можливо було визначити візуально.

На субстратах № 7-11 спостерігали міцелій білого кольору з великою кількістю повітряних гіф, окремі компоненти субстрату були добре помітні.

На субстраті № 7 (зерно пшениці/лісова підстилка) зерно та хвоя не проглядалися, але гілочки хвойних можна було добре роздивитися (рис. 3, В). Стружку та/або солому, на відміну від зерна пшениці, добре видно було й на 20-ту добу експерименту на субстратах № 10 (рис. 3, С), № 11 (рис. 3, D), № 8 i № 9. Зважаючи на те, що рівень обростання цих субстратів не перевищував $28-50 \%$, тобто повного обростання субстратів так і не відбулося, можна припустити, що використання соломи та/чи стружки хвойних у комбінаціях, запропонованих у нашому експерименті в субстратах № 8-11, виявилось зайвим.

Відмітимо, що в лабораторних умовах ми не отримали характерних плодових тіл гриба. Причиною утворення лише деформованих плодових тіл може бути як недостатня вага використаного в експерименті субстрату (600 г), так i невдало підібрані оптимальні умови культивування (температура, світло, $\mathrm{pH}$ тощо). Імовірно, слід також відкоригувати співвідношення компонентів субстрату. Перевірка цього припущення потребує подальших експериментів 3 вирощування $S$. петесіi в лабораторії. Зауважимо, що в літературі наводиться морфологія виключно зрілих плодових тіл гриба $S$. петесіi в природі, без опису процесу їхнього формування. 

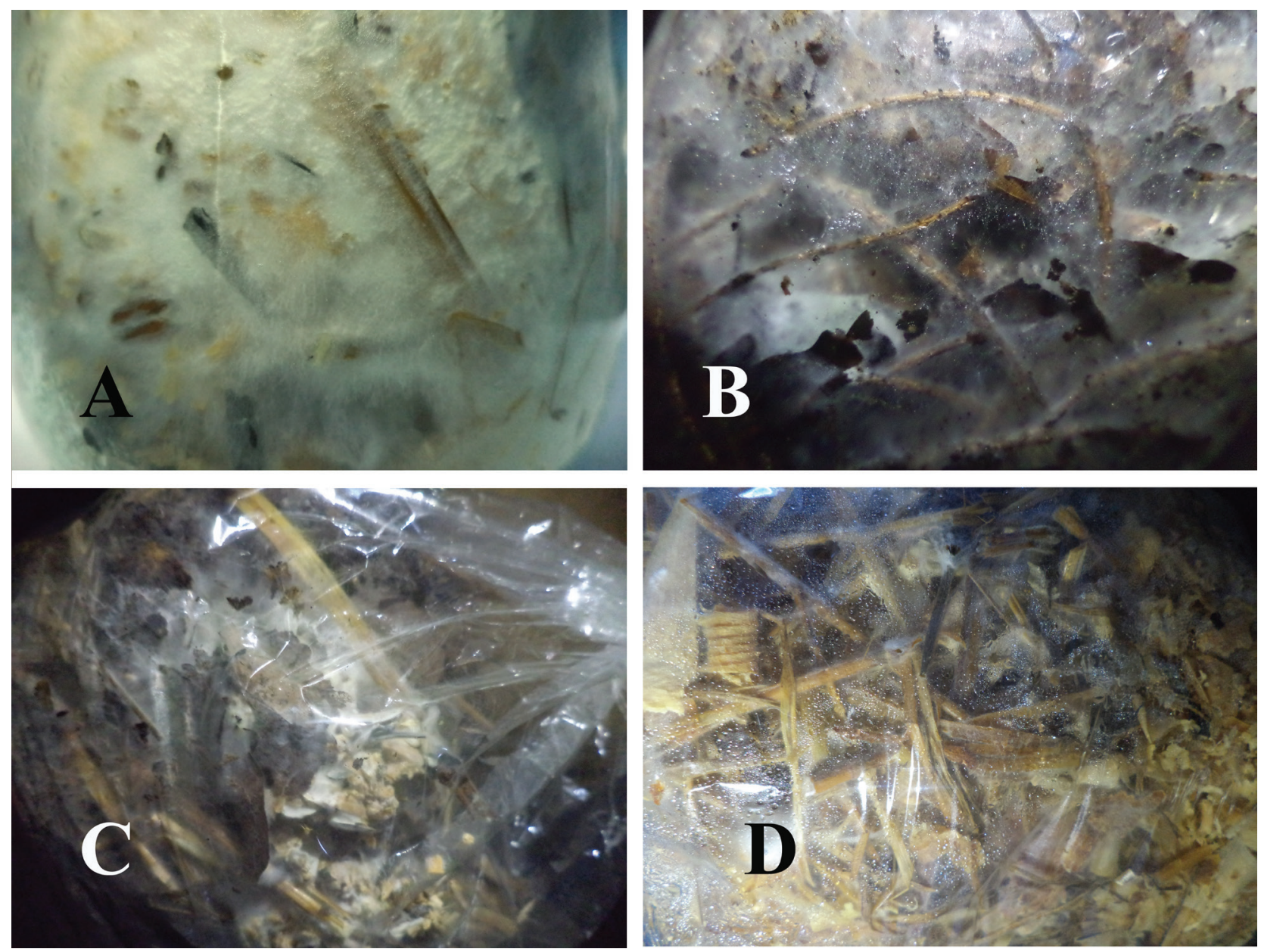

Рис. 3. Міцелій Sparassis neтесіi 2327 на комбінованих субстратах на 20-ту добу експерименту. А: на субстраті № 2; В: на субстраті № 7; С: на субстраті № 10; D: на субстраті № 11

Fig. 3. Mycelium of Sparassis nemecii 2327 on combined substrates. A: substrate no. 2; B: substrate no. 7; C: substrate no.10; D: substrate no. $11,20^{\text {th }}$ day of experiment

\section{Висновки}

Досліджена специфіка росту та морфологічні особливості Sparassis nemecii 2327 на рослинних субстратах різного складу. В лабораторних умовах підібрані компоненти субстратів, співвідношення та механічні характеристики яких придатні для отримання міцелію гриба. Встановлено, що для успішного вирошування міцелію $S$. петесіi обов'язковим компонентом є зерно пшениці. Важливими факторами також $є$ природа складових, спосіб їхнього комбінування та механічні властивості субстрату. Встановлено, що міцелій $S$. петесіi краще росте на субстраті, компоненти якого розташовуються щільно. Цим критеріям відповідають субстрати "зерно пшениці/ стружка хвойних/лушпиння соняшника/солома пшениці" та "зерно пшениці/лісова підстилка," шо мають найоптимальнішу композицію для вирощування міцелію $S$. петесіi в лабораторних умовах. Ступінь обростання цих субстратів на 25ту добу експерименту склав $85 \%$ та $75 \%$ відповідно.

В лабораторних умовах ми не отримали характерних для природних умов плодових тіл гриба. Подальші експерименти, присвячені вирощуванню плодових тіл Sparassis nemecii в лабораторії, будуть пов'язані із коригуванням ваги субстратів та співвідношенням їхніх компонентів, підбором оптимальних умов культивування (температура, світло, $\mathrm{pH}$ тощо) 3 урахуванням отриманих відомостей щодо специфіки росту міцелію гриба. 


\section{Подяки}

Автор висловлює щиру подяку співробітникам відділу мікології Інституту ботаніки ім. М.Г. Холодного НАН України Н.А. Бісько, М.Л. Ломберг, О.Б. Михайловій за надану для досліджень культуру Sparassis neтесіi 2327.

\section{СПИСОК ПОСИЛАНЬ}

Bisko N.A., Lomberg M.L., Mytropolska N.Yu., Mykchaylova O.B. 2016. Kolektsiya kultur shapynkovykh hrybiv (IBK) (IBK Mushroom Culture Collection). Kyiv: Alterpress, 120 pp. [Бісько Н.А., Ломберг М.Л., Митропольська Н.Ю., Михайлова О.Б. 2016. Колекція культур шапинкових грибів (IВК). Київ: Альтерпрес, $120 \mathrm{c.}]$.

Heluta V.P. 2009. Sparassis crispa. In: Chervona knyha Ukrainy. Roslynnyi svit (Red Data Book of Ukraine. Plant Kingdom). Ed. Ya.P. Didukh. Kyiv: Globalkonsaltyng, p. 831. [Гелюта В.П. 2009. Sparassis crispa. В кн.: Червона книга Украӥни. Рослинний світ. Ред. Я.П. Дідух. Київ: Глобалконсалтинг, с. 831].

Heluta V.P., Fokshei S.I., Derzhypilskyi L.M. 2016. In: Rare plants and fungi of Ukraine and adjacent areas: implementing conservation strategies. Abstracts of the fourth International conference. Kyiv: Palyvoda, pp. 182-184. [Гелюта В.П., Фокшей С.І., Держипільський Л.М. 2016. Перші знахідки в Україні рідкісного гриба Sparassis neтесіi (Sparassidaceae). У зб.: Рідкісні рослини і гриби України та прилеглих територій: реалізація природоохоронних стратегій: матеріали четвертої міжнародної наукової конфренції (Київ, 16-20 травня, 2016 р.). Київ: Паливода, с. 182-184].
Holec J., Beran M. [Eds] 2006. Červený seznam hub (makromycetů) České republiky [Red list of fungi (macromycetes) of the Czech Republic]. Príroda, 24: 1-282.

Leshan T.A., Pakhomov O.Y. 2009. Visnyk of Dnipropetrovsk University. Series Biology. Ecology, 17(1): 115-120. [Лешан Т.А., Пахомов О.Є. 2009. Раритетний фонд базидіоміцетів сходу України. Вісник Дніпропетровського університету. Серія Біологія. Екологія, 17(1): 115-120].

Lomberg M.L., Mykchaylova O.B., Bisko N.A. 2015. Mushroom culture collection (IBK) as a subject of national heritage of Ukraine. Ukrainian Botanical Journal, 72(1): 22-28. http://doi.org/10.15407/ukrbotj72.01.022

Mykchaylova O.B. 2017. In: Environmental, historical, cultural and ecoeducational aspects of Ukrainian Carpathians balanced development: materials of International research and practical conference dedicated to the $15^{\text {th }}$ anniversary of Hutsulshchyna National Park. Kosiv: PP Pavliuk, pp. 243-245. [Михайлова О.Б. 2017. Культурально-морфологічні властивості рідкісного гриба Sparassis nemecii (Sparassidaceae, Polyporales). У зб.: Природоохоронні, історико-культурні та екоосвітні аспекти збалансованого розвитку Українських Карnат: матеріали міжннародної науково-практичної конференції, присвяченої 15-й річниці НПП "Гуцульщина" (Косів, 8-9 червня 2017 р.). Косів: ПП Павлюк, c. 243-245].

Pasailiuk M., Petrichuk Yu., Tsvyd N., Sukhomlyn M. 2018. The aspects of reproduction of Clathrus archeri (Berk.) Dring by re-situ method in the National Nature Park Hutsulshchyna. Leśne Prace Badawcze, 79(3): 287-293.

Рекомендує до друку М.M. Сухомлин 
https://doi.org/10.15407/ukrbotj76.06.499

\title{
Адвентизація ценофлор класів піонерної рослинності України
}

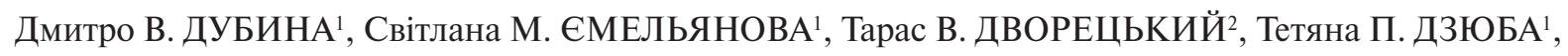 \\ Павло А. ТИМОШЕНКО ${ }^{1}$ \\ ${ }^{1}$ Інститут ботаніки ім. М.Г. Холодного НАН України \\ вул. Терещенківська 2, Київ 01004, Україна \\ geobot@ukr.net \\ ${ }^{2}$ Інститут гідробіології НАН України \\ проспект Героїв Сталінграда 12, Київ 04210, Україна
}

Dubyna D.V. ${ }^{1}$, Iemelianova S.M. ${ }^{1}$, Dvoretzkiy T.V. ${ }^{2}$, Dziuba T.P. ${ }^{1}$, Tymoshenko P.A. ${ }^{1}$ 2019. Adventization of coenofloras of the classes of pioneer vegetation in Ukraine. Ukrainian Botanical Journal, 76(5): 499-510.

${ }^{1}$ M.G. Kholodny Institute of Botany, National Academy of Science of Ukraine

2 Tereschenkivska Str., Kyiv 01004, Ukraine

geobot@ukr.net

${ }^{2}$ Institute of Hydrobiology, National Academy of Science of Ukraine

12, Prospect Geroiv Stalingradu, Kyiv 04210, Ukraine

Abstract. The article presents the results of an analysis of the alien fraction of coenofloras of the classes of pioneer vegetation of Ukraine. In plant communities of the newly formed ecotopes, 113 alien species of 32 families and 88 genera were identified. A value of the general index of adventization of coenofloras of the classes of pioneer vegetation of Ukraine is $13.4 \%$. The highest level of anthropogenization was established for the plant communities of Bidentetea, Cakiletea maritimae and IsoëtoNanojuncetea. The leading families of the alien fraction of the studied coenofloras are Asteraceae, Brassicaceae and Poaceae. It has been revealed that terophytes prevail in the biomorphological spectrum of the alien fraction of coenofloras of the classes of pioneer vegetation in Ukraine. The ecological analysis of alien species has shown the predominance of the species with a very wide ecological plasticity in relation to all abiotic factors. It was established that in the investigated coenofloras kenophytes predominate by the time of immigration, and epecophytes - by the degree of naturalization. The analysis and comparison of species composition of the alien fractions of the typological floras of pioneer plant communities by means of Jaccard indices showed the highest similarity between the Isoëto-Nanojuncetea and Bidentetea classes, as well as Festucetea vaginatae and Helichryso-Crucianelletea maritimae. For determination of the degree of anthropogenic transformation of coenofloras of the classes of pioneer vegetation of Ukraine, the indexes of archeophytization, kenophytization, modernization and fluctuation of the flora have been calculated. It has been established that 26 species of 11 families and 25 genera are invasive. Among them, Amorpha fruticosa, Ambrosia artemisiifolia, Anisantha tectorum, Apera spica-venti, Bidens frondosa, Centaurea diffusa, Conyza canadensis, Echinocystis lobata, Elaeagnus angustifolia, Impatiens glandulifera, Solidago canadensis and Phalacroloma annuum are transformers, which constitute the greatest threat to pioneer vegetation due to their diverse impacts.

Keywords: alien species, anthropogenic transformation, invasions, plant communities, transformer species, flora, Ukraine

Submitted 02 July 2019. Published 29 December 2019

(C) 2019 D.V. Dubyna, S.M. Iemelianova, T.V. Dvoretzkiy, T.P. Dziuba, P.A. Tymoshenko. Published by the M.G. Kholodny Institute of Botany, NAS of Ukraine. This is an open access article under the terms of the Creative Commons Attribution License (http://creativecommons.org/ licenses/by/4.0/), which permits use, distribution, and reproduction in any medium, provided the original work is properly cited 
Дубина Д.В., Ємельянова С.М., Дворецький Т.В., Дзюба Т.П., Тимошенко П.А. 2019. Адвентизація ценофлор класів піонерної рослинності України. Український ботанічний журнал, 76(5): 499-510.

Реферат. У статті представлені результати аналізу адвентивних фракцій ценофлор класів піонерної рослинності України. В угрупованнях новоутворених місцезростань виявлено 113 неаборигенних видів з 32 родин та 88 родів. Загальний індекс адвентизації ценофлор класів піонерної рослинності України становить 13,4\%. Встановлено, що найвищим ступенем антропогенізації відзначаються ценози Bidentetea, Cakiletea maritimae та Isoëto-Nanojuncetea. До провідних родин адвентивної фракції досліджених ценофлор належать Asteraceae, Brassicaceae та Poaceae. Виявлено, що у біоморфологічному спектрі адвентивної фракції ценофлор класів піонерної рослинності України значно переважають терофіти. Екологічний аналіз видів неаборигенних рослин засвідчив переважання евритопів із дуже широкою екологічною пластичністю по відношенню до усіх абіотичних факторів. Встановлено, що за часом занесення у досліджених ценофлорах переважають кенофіти, за ступенем натуралізації- епекофіти. Проведено аналіз та порівняння видового складу неаборигенних компонент типологічних флор піонерних угруповань за допомогою коефіцієнта Жаккара, виявлено найбільшу подібність між класами Isoëto-Nanojuncetea та Bidentetea, а також Festucetea vaginatae та Helichryso-Crucianelletea maritimae. Для визначення ступеня антропогенної трансформації ценофлор класів піонерної рослинності України обчислено показники археофітизації, кенофітизації, модернізації та нестабільності флори. Встановлено, що найбільшою інвазійною спроможністю відзначаються 26 видів 311 родин та 25 родів. Серед них найбільшу небезпеку для піонерних угруповань становлять види-трансформери - Amorpha fruticosa, Ambrosia artemisiifolia, Anisantha tectorum, Apera spica-venti, Bidens frondosa, Centaurea diffusa, Conyza canadensis, Echinocystis lobata, Elaeagnus angustifolia, Impatiens glandulifera, Solidago canadensis та Phalacroloma annиит, які здійснюють різні впливи за ступенем і характером.

Ключові слова: адвентивні види, антропогенна трансформація, види-трансформери, інвазії, рослинні угруповання, флора, Україна

\section{Ветуп}

На сучасному етапі розвитку продуктивних сил усі екосистеми знаходяться під антропогенним впливом. Одним із його проявів є культивування із подальшим проникненням у антропогенні біотопи чужорідних рослин або їхнє спонтанне поширення. Занесення та натуралізація неаборигенних видів, глобальний характерцихпроцесів, їхній негативний вплив не лише на біорізноманіття та природні явища, а й на соціально-економічні процеси досягають неабияких розмірів, привертаючи увагу багатьох фахівців та міжнародних організацій (Protopopova et al., 2002).

На території України процес адвентизації набув загрозливого характеру та постав реальною небезпекою для місцевого фітогенофонду. Від нього потерпають майже всі рослинні угруповання, оскільки кількість неаборигенних видів невпинно зростає, а їхні фітоценотичний та біотопічний спектри постійно розширюються. 3 огляду на це посиленої уваги заслуговують особливо вразливі типи організації рослинності, зокрема піонерна. У зв'язку із підвищеною флуктуаційною активністю та високою інтенсивністю екологічних процесів вона має особливий склад та механізми стійкості, відмінні від ценозів більш стабільних місцезростань (Dubyna et al., 2016). Водночас така мінливість факторів середовища забезпечує виключно важливу роль піонерних угруповань у розвитку адаптаційних та формотворчих процесів. Зростаючи нерідко в умовах екологічних екстремумів, піонерна рослинність $€$ надзвичайно вразливою до абіотичних чи біотичних змін.

Поширення та особливо інвазії видів адвентивних рослин в піонерні угруповання, які характеризуються послабленими ценотичними зв'язками i низькою антропотолерантністю, $€$ надзвичайно небезпечним процесом, що призводить до зниження флористичної та ценотичної різноманітності даних фітосистем, спрощення їхньої структури, порушення функціональної ролі, а подекуди й до цілковитого знищення.

Тому вкрай важливо дослідити неаборигенні компоненти флористичних комплексів угруповань піонерної рослинності та з'ясувати головні напрямки й тенденції процесу адвентизації для запобігання незворотних фітоценотичних втрат.

Метою роботи є виявлення видового складу адвентивної фракції ценофлор (типологічних флор) класів піонерної рослинності України та здійснення його аналізу для виявлення основних тенденцій і потенційних загроз.

\section{Матеріали та методи}

Об'єктами дослідження є ценофлори класів Ammophiletea Br.-Bl. et Tx. ex Westhoff et al. 1946, Bidentetea Tx. et al. ex von Rochow 1951, Cakiletea maritimae Tx. et Preising in Tx. ex Br.-Bl. et Tx. 1952, Crithmo-Staticetea Br.-B1. in Br.-Bl. et al. 1952, 
Crypsietea aculeatae Vicherek 1973, Festucetea vaginatae Soó ex Vicherek 1972, Helichryso-Crucianelletea maritimae Géhu et all in Sissingh 1974, KoelerioCorynephoretea canescentis Klika in Klika et Novák 1941, Isoëto-Nanojuncetea Br.-B1. et Tx. in Br.-Bl. et al. 1952 та Therosalicornietea Tx. in Tx. et Oberd. 1958. Для проведення класифікації піонерної рослинності та складання списків видів адвентивних рослин у роботі використано геоботанічні описи новоутворених екотопів України, зроблених авторами, та іншими дослідниками (Dubyna et al., 2016a).

Систематична структура адвентивної фракції ценофлор досліджувалася за підходами, запропонованими O.I. Толмачовим (Tolmachev, 1974). Структура клімаморфотипів подана за К. Раункієром. Прийнято монотиповий стандарт виду. Номенклатура таксонів подана відповідно до таксономічного видання "Vascular plants of Ukraine. A nomenclatural cheklist" (Mosyakin, Fedoronchuk, 1999).

Використано історико-географічну класифікацію адвентивних видів за J. Kornaś (1968). Для оцінки ступеня антропогенної трансформації флори застосовано індекси, запропоновані В. Jackowiak (1990), які визначають відсоткову участь різних шодо антропопресії груп у досліджуваних ценофлорах. Аналіз подібності флор здійснювали за допомогою коефіцієнтів Жаккара (Shmidt, 1980).

\section{Результати та обговорення}

Піонерна рослинність України представлена 84 асоціаціями, які об'єднані у 21 союз, 10 порядків та 10 класів, що репрезентують псамофітні, галофітні, літоральні та гігрофільні фітоценосистеми. На новоутворених піщаних екотопах формуються угруповання кількох класів. Так, клас Festucetea vaginatae представляє псамофітні степи, Helichryso-Crucianelletea maritimae об'єднує ценози стабілізованих зарослих (сірих) дюн. Клас KoelerioCorynephoretea canescentis включає угруповання, що розвиваються на слабкосформованих рухливих силікатних малопотужних грунтах.

Галофітні піонерні фітоценокомплекси репрезентовані класом Therosalicornietea (його утворюють здебільшого однорічні сукуленти на ділянках що періодично заливаються) та класом Crypsietea aculeatae, що складений облігатно галофітними та слабконітрофільними угрупованнями. Літоральна піонерна рослинність представлена класами Ammophiletea (репрезентує угруповання піщаних дюн морських узбереж), Cakiletea maritimae (об'єднує галонітрофільну рослинність піщаних та галькових морських узбереж біля верхньої межі прибою) і CrithmoStaticetea (включає ценози валунно-галькових пляжів абразійних берегів, що формуються під впливом морських солоних бризок). На перезволожених новоутворених місцезростаннях формуються угруповання класу Isoëto-Nanojuncetea, який включає унікальні рослинні комплекси низькорослих терофітів 3 коротким терміном онтогенезу, та класу Bidentetea, що представляє піонерні угруповання високорослих однорічників.

За даними польових досліджень авторів та літературними матеріалами ценофлори класів піонерної рослинності України загалом нараховують 844 види судинних рослин, які належать до 338 родів і 80 родин (Dubyna et al., 2017). В їхньому складі є чужорідними 113 видів із 88 родів, 32 родин, 2 класів, 1 відділу (Magnoliophyta).

Загальний індекс адвентизації ценофлор класів піонерної рослинності України становить $13,4 \%$ і суттєво не відрізняється від аналогічного показника для флори України в цілому (14\%) (Protopopova et al., 2002). Серед рослинних угруповань найвищим ступенем антропогенізації відзначаються ценози Bidentetea $(33,0 \%)$, Cakiletea maritimae $(21,3 \%)$ та Isoëto-Nanojuncetea $(17,6 \%)$ (рис. 1). Це зумовлено тим, що ценози класів займають перезволожені нітрифіковані екотопи, де умови є цілком сприятливі для появи видів адвентивних рослин та успішної реалізації ними своїх еколого-ценотичних стратегій. Близький до загального індексу мають типологічні флори класів Ammophiletea та Helichryso-Crucianelletea maritimae. Найменша кількість неаборигенів відмічена у складі угруповань Therosalicornietea, Festucetea vaginatae та Koelerio-Corynephoretea canescentis. Невеликий відсоток алохтонного компоненту в ценофлорах цих класів пояснюється лімітуючим впливом провідних факторів екологічної диференціації їхніх угруповань. Для Therosalicornietea це високі концентрації мінеральних солей у грунті, для Festucetea vaginatae та Koelerio-Corynephoretea canescentis - підвищена кислотність грунтового розчину.

У систематичному спектрі адвентивної фракції ценофлор класів піонерної рослинності України домінують представники класу Magnoliopsida, їхня питома вага досягає $84,1 \%$, на Liliopsida припадає відповідно 15,9\% видів (табл. 1). 


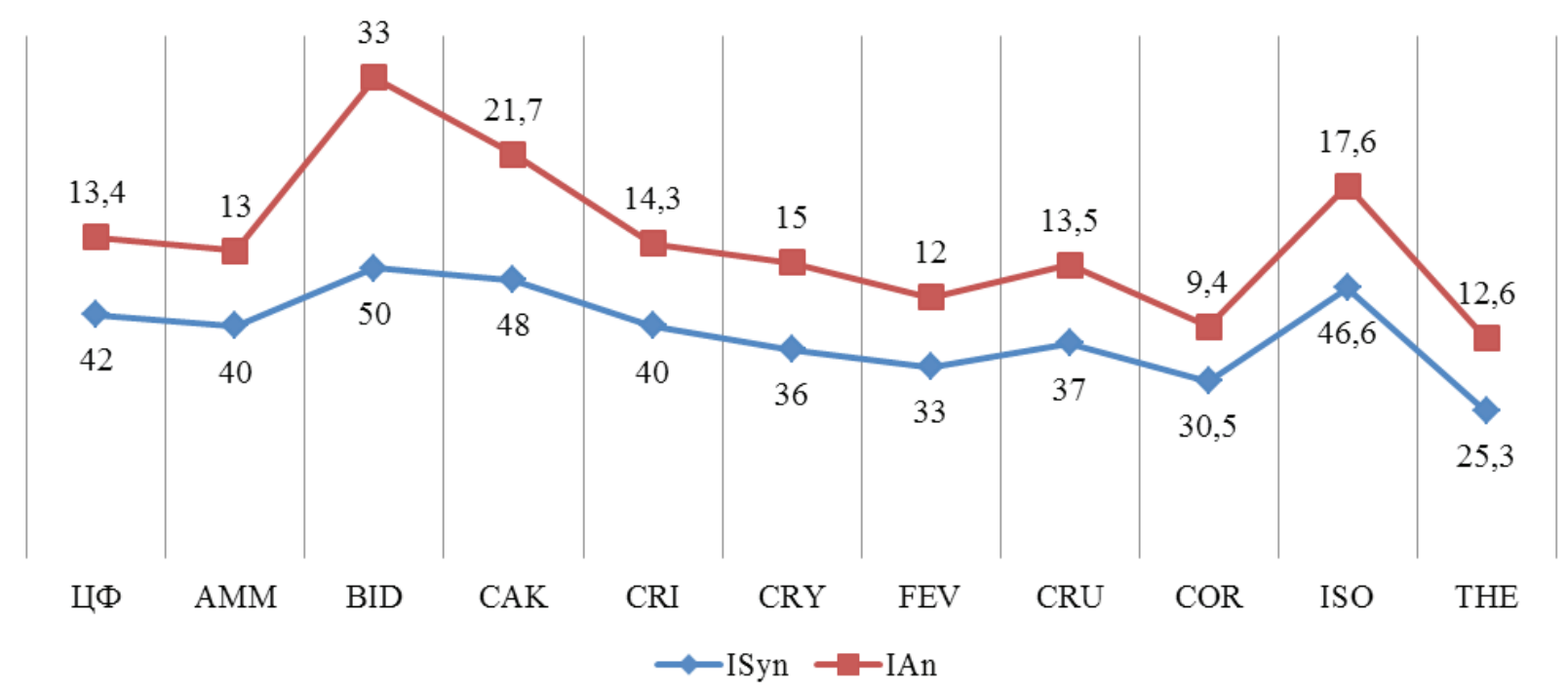

Рис. 1. Індекси синантропізації (ISyn) та антропогенізації (IAn) у ценофлорах класів піонерної рослинності України. Тут і далі в рисунках і таблицях: ЦФ - ценофлори класів піонерної рослинної України. Для позначення окремих класів використано мнемокоди, запропоновані Л. Муциною зі співавторами (Mucina et al., 2016): AMM - Ammophiletea, BID - Bidentetea, CAK - Cakiletea maritimae, CRI - Crithmo-Staticetea, CRY - Crypsietea aculeatae, FEV - Festucetea vaginatae, CRU - Helichryso-Crucianelletea maritimae, ISO - Isoëto-Nanojuncetea, COR - Koelerio-Corynephoretea canescentis, THE - Therosalicornietea

Fig. 1. Synanthropogenization (ISyn) and anthropogenization (IAn) indices values of coenofloras of the classes of pioneer vegetation in Ukraine.

Here and below: ЦФ - coenofloras of classes of pioneer vegetation in Ukraine. Classes are accepted following L.Mucina et al. (2016): AMM - Ammophiletea, BID - Bidentetea, CAK - Cakiletea maritimae, CRI - Crithmo-Staticetea, CRY Crypsietea aculeatae, FEV - Festucetea vaginatae, CRU - Helichryso-Crucianelletea maritimae, ISO - Isoëto-Nanojuncetea, COR - Koelerio-Corynephoretea canescentis, THE - Therosalicornietea

Десять провідних родин адвентивної фракції ценофлор класів піонерної рослинності об'єднують 88 видів або 76,2\% їхньої загальної кількості (табл. 2). На перші три родини припадає 55,8\% усього флористичного списку. Спектр провідних родин адвентивної фракції досліджених ценофлор загалом відповідає аналогічному для флори

Таблиця 1. Кількісний розподіл таксономічних одиниць i основні флористичні пропорції адвентивної фракції ценофлор класів піонерної рослинності України

Table 1. Quantitative distribution of taxa and main floristic proportions of the alien fraction of coenofloras of the classes of pioneer vegetation in Ukraine

\begin{tabular}{|l|c|c|c|c|c|c|c|}
\hline \multirow{3}{*}{ Класи } & \multicolumn{5}{|c|}{ Кількість } & \multirow{2}{*}{ Пропорції } \\
\cline { 2 - 7 } & \multicolumn{2}{|c|}{ родин } & \multicolumn{2}{|c|}{ родів } & \multicolumn{2}{|c|}{ видів } & \\
\cline { 2 - 7 } & абс. & $\%$ & абс. & $\%$ & абс. & $\%$ & \\
\hline Magnoliopsida & 28 & 87,5 & 75 & 85,2 & 95 & 84,1 & $1,0: 2,7: 3,4$ \\
\hline Liliopsida & 4 & 12,5 & 13 & 14,8 & 18 & 15,9 & $1,0: 3,25: 4,5$ \\
\hline Всього & 32 & 100 & 88 & 100 & 113 & 100 & $1,0: 2,75: 3,5$ \\
\hline
\end{tabular}

України в цілому (Protopopova, 1991). Зокрема, перше та друге місця за кількістю видів неаборигенних рослин займають Asteraceae (26; 23\%) та Brassicaceae $(22 ; 19,5 \%)$ відповідно. До складу найчисельніших родин також входять Роасеае (15; 13,3\%), Chenopodiaceae $(6 ; 5,3 \%)$, Fabaceae $(5 ; 4,4 \%)$ та Lamiaceae $(4 ; 3,5 \%)$. Такий розподіл вказує на середземноморський характер спектра та суттєву роль аридних флористичних центрів у формуванні адвентивного ядра досліджених ценофлор.

За аналізом таксономічних спектрів адвентивних фракцій різних угруповань піонерної рослинності в систематичному положенні провідних родин виявлено певні відмінності, що корелюють із ботаніко-географічними та екологічними особливостями окремих класів.

Встановлено, що як і в загальному розподілі представники Asteraceae переважають в угрупованнях Ammophiletea, Bidentetea, Crithmo- 


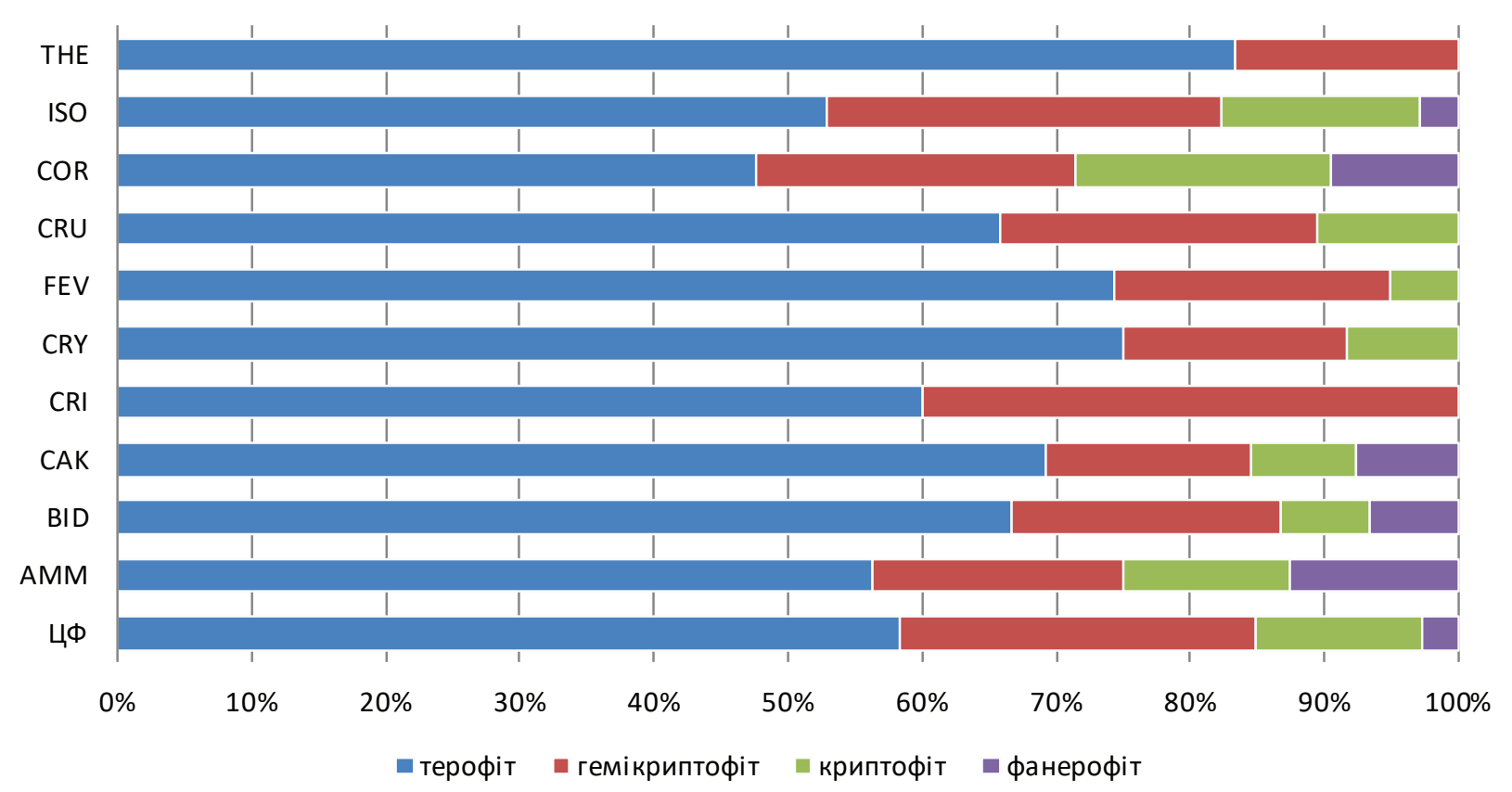

Рис. 2. Розподіл видів адвентивної фракції ценофлор класів піонерної рослинності України за клімаморфами Fig. 2. Distribution of alien species of coenofloras of the classes of pioneer vegetation in Ukraine

Staticetea, Crypsietea aculeatae та Isoëto-Nanojuncetea. Натомість родина Brassicaceae очолює систематичні спектри Cakiletea maritimae, Festucetea vaginatae та Helichryso-Crucianelletea maritimae. А в ценозах Therosalicornietea однаково високу питому вагу мають представники вище наведених родин, а також види Chenopodiaceae.

Родовий спектр адвентивної фракції досліджених ценофлор загалом формують 88 родів, з яких більшість - 67 (76,1\%) є моновидовими. $20(22,7 \%)$ родів нараховують 2-4 види, один рід $(1,2 \%)$ представлений п'ятьма таксонами. Провідні роди об'єднують третину $(30,6 \%)$ усіх видів, середня кількість останніх у роді становить 1,3 . Очолюють родовий спектр типові аридні Sisymbrium (5 видів), Lepidium (4), Anisantha (3) та Atriplex (3 види).

Біоморфологічна структура видів адвентивної фракції ценофлор класів піонерної рослинності $€$ подібною до відповідного спектра неаборигенних видів України (Protopopova, 1991). Характерною особливістю досліджених ценофлор є значна питома вага терофітів, яких більше половини (66 видів або 58,4\% загальної кількості). Така перевага зберігається в межах усіх класів піонерної рослинності та є відображенням несприятливих, подекуди екстремальних, екологічних умов, Український ботанічний журнал, 2019, 76(6)
Таблиця 2. Спектр провідних родин адвентивної фракції ценофлор класів піонерної рослинності України Table 2. Spectrum of the leading families of the alien fraction of coenofloras of the classes of pioneer vegetation in Ukraine

\begin{tabular}{|c|c|c|c|c|c|}
\hline \multirow{2}{*}{ Ранг } & \multirow{2}{*}{ Родина } & \multicolumn{4}{|c|}{ Кількість } \\
\hline & & родів & $\%$ & видів & $\%$ \\
\hline 1 & Asteraceae & 20 & 22,7 & 26 & 23,0 \\
\hline 2 & Brassicaceae & 13 & 14,8 & 22 & 19,5 \\
\hline 3 & Poaceae & 10 & 11,4 & 15 & 13,3 \\
\hline 4 & Chenopodiaceae & 5 & 5,7 & 6 & 5,3 \\
\hline 5 & Fabaceae & 4 & 4,5 & 5 & 4,4 \\
\hline 6 & Lamiaceae & 4 & 4,5 & 4 & 3,5 \\
\hline 7 & Onagraceae & 2 & 2,3 & 3 & 2,7 \\
\hline 8 & Caryophyllaceae & 3 & 3,4 & 3 & 2,7 \\
\hline $9-10$ & Ranunculaceae & 2 & 2,3 & 2 & 1,8 \\
\hline $9-10$ & Cucurbitaceae & 2 & 2,3 & 2 & 1,8 \\
\hline \multicolumn{2}{|c|}{ У трьох провідних родинах } & 43 & 48,9 & 63 & 55,8 \\
\hline \multicolumn{2}{|c|}{ У десяти провідних родинах } & 65 & 74,7 & 88 & 76,2 \\
\hline
\end{tabular}

у яких формуються угруповання даного типу організації (рис. 2). Частки гемікриптофітів та криптофітів менші й досягають у загальному біоморфологічному спектрі 26,5\% (30 видів) та 
Таблиця 3. Розподіл видів адвентивної фракції ценофлор класів піонерної рослинності України за екологічними групами залежно від абіотичних чинників

Table 3. Distribution of alien species of coenofloras of pioneer vegetation's classes of Ukraine by ecological groups depending on abiotic factors

\begin{tabular}{|c|c|c|c|c|c|}
\hline \multirow{2}{*}{ Екогрупи } & \multicolumn{2}{|c|}{ Кількість видів } & \multirow{2}{*}{ Екогрупи } & \multicolumn{2}{|c|}{ Кількість видів } \\
\hline & абсолютна & $\%$ & & абсолютна & $\%$ \\
\hline \multicolumn{3}{|l|}{ Hd } & \multicolumn{3}{|l|}{ SI } \\
\hline субмезофіт & 41 & 36,3 & семіевтроф & 52 & 46,0 \\
\hline мезофіт & 31 & 27,4 & евтроф & 34 & 30,1 \\
\hline субксерофіт & 21 & 18,6 & субглікотроф & 13 & 11,5 \\
\hline гігромезофіт & 12 & 10,6 & мезотроф & 9 & 8,0 \\
\hline гігрофіт & 4 & 3,5 & глікотроф & 3 & 2,6 \\
\hline ксерофіт & 2 & 1,8 & мезогалотроф & 1 & 0,9 \\
\hline пергідрофіт & 1 & 0,9 & семіоліготроф & 1 & 0,9 \\
\hline субгідрофіт & 1 & 0,9 & $\mathrm{Ca}$ & & \\
\hline \multicolumn{3}{|l|}{ Re } & гемікарбонатофоб & 50 & 44,3 \\
\hline субацидофіл & 53 & 46,9 & акарбонатофіл & 36 & 31,9 \\
\hline нейтрофіл & 50 & 44,3 & гемікарбонатофіл & 18 & 15,9 \\
\hline базифіл & 4 & 3,5 & карбонатофоб & 6 & 5,3 \\
\hline ацидофіл & 4 & 3,5 & карбонатофіл & 3 & 2,6 \\
\hline перацидофіл & 2 & 1,8 & \multicolumn{3}{|l|}{ fH } \\
\hline \multicolumn{3}{|l|}{$\mathbf{N t}$} & гемігідроконтрастофіл & 52 & 46,0 \\
\hline гемінітрофіл & 49 & 43,4 & гідроконтрастофіл & 29 & 25,7 \\
\hline нітрофіл & 46 & 40,7 & гемігідроконтрастофоб & 17 & 15,1 \\
\hline субанітрофіл & 11 & 9,7 & гіпергідроконтрастофіл & 12 & 10,6 \\
\hline еунітрофіл & 7 & 6,2 & гідроконтрастофоб & 3 & 2,6 \\
\hline
\end{tabular}

$\mathrm{Hd}$ - водний режим грунту, $\mathrm{Sl}$ - загальний сольовий режим грунту, $\mathrm{Rc}-$ реакція грунтового розчину, Сa - вміст карбонатів у грунті, $\mathrm{Nt}$ - вміст у грунті засвоюваних форм азоту, fH - змінність зволоження

12,4\% (14 видів) відповідно. Фанерофіти (2,7\%, 3 види) представлені незначною кількістю видів, що є характерною рисою неаборигенних компонент в цілому.

Екологічна структура адвентивної фракції досліджених ценофлор визначається комплексною дією багатьох факторів, а розподіл за основними екологічними групами повною мірою відображає значну мінливість провідних абіотичних чинників, зокрема насиченості грунтів елементами водномінерального живлення та інтенсивності еолових та алювіальних процесів і згінно-нагінних явищ.

У загальному спектрі гідроморф переважають субмезофіти $(36,3 \%)$, дещо менше мезофітів $(27,4 \%)$, субксерофітів $(18,3 \%)$ та гігромезофітів $(10,6 \%)$ (табл. 3). Питома вага інших екогруп неаборигенних видів за вимогливістю до водного режиму екотопу є значно нижчою. При аналізі спектру адвентів угруповань піонерної рослинності на відношення до зміни зволоження виявлено переважання видів, що зростають в умовах помірного та незначного зволоження кореневмісного шару грунту. Найчисельнішими за даним абіотичним чинником виявилися групи гемігідроконтрастофілів (46\%) та гідроконтрастофілів $(25,7 \%)$. За відношенням до кислотності середовища види адвентивних рослин досліджених ценофлор розподілилися переважно між субацидофільною та нейтрофільною групами, до складу яких увійшло 46,9\% та 44,3\% представників відповідно. Екологічний спектр за сольовим режимом едафотопу засвідчив, що неаборигени в піонерних угрупованнях тяжіють до субстратів, добре забезпечених мінеральними сполуками. Зокрема, найбільшою чисельністю відзначаються семіевтрофи (46\%) та евтрофи $(30,1 \%)$. Частка видів адвентивних рослин, що витримують надмірне засолення, у досліджуваних ценофлорах загалом $€$ незначною. За вмістом засвоюваних форм азоту в типологічних флорах піонерних угруповань переважають гемінітрофіли $(43,4 \%)$ та нітрофіли $(40,7 \%)$. В екологічному спектрі за карбонатністю субстрату більшість адвентів розділилися між трьома екологічними 


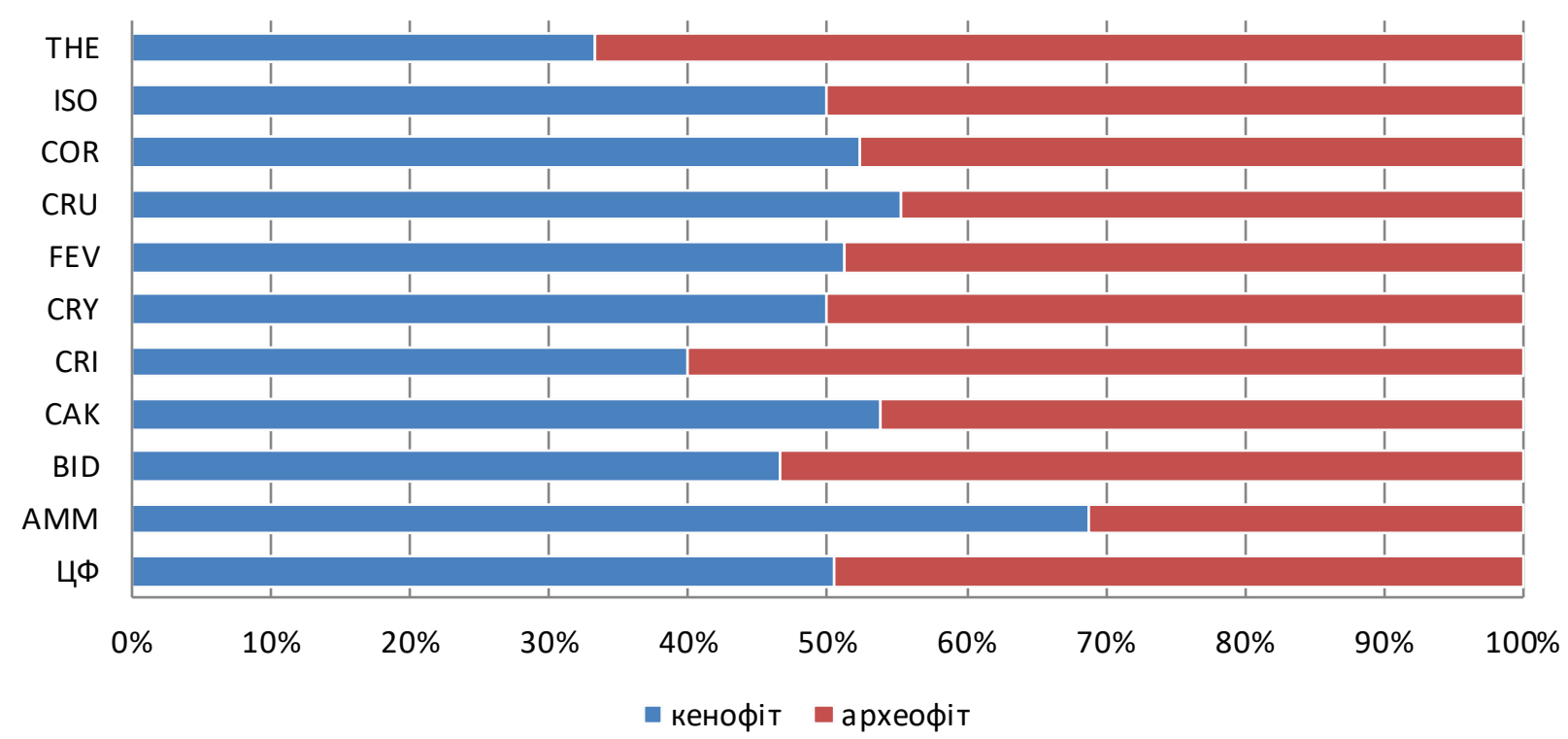

Рис. 3. Розподіл мігрохроноелементів у ценофлорах класів піонерної рослинності України

Fig. 3. Distribution of migrochronoelements in coenofloras of the classes of pioneer vegetation in Ukraine

групами: гемікарбонатофобною $\quad(44,2 \%)$, акарбонатофільною $(31,9 \%)$ та гемікарбонатофільною $(15,9 \%)$.

Аналіз розподілу видів адвентивних фракцій у межах класів піонерної рослинності України за провідними абіотичними чинниками засвідчив у цілому відповідність загальній диференціації між екологічними групами. Відмінності виявлені для неаборигених компонент окремих типів угруповань. Зокрема, для екологічного спектру видів алохтонних рослин Ammophiletea властиве переважання мезофітів. Екологічний розподіл неаборигенів в угрупованнях Bidentetea, Crypsietea aculeatae та Isoëto-Nanojuncetea відзначається високою відсотковою участю гігромезофітних видів та домінуванням нітрофілів. У алохтонному елементі ценофлор Festucetea vaginatae та HelichrysoCrucianelletea maritimae виявлене незначне переважання акарбонатофілів. А в екологічних спектрах Cakiletea maritimae, Therosalicornietea та Crypsietea aculeatae превалюють види адвентивних рослин, які здатні зростати в умовах надлишкового засолення.

Характерною особливістю екологічної структури адвентивної фракції ценофлор класів піонерної рослинності України, як в цілому, так і в межах окремих угруповань є переважання евритопних видів із дуже широкою екологічною пластичністю по відношенню до усіх абіотичних факторів, що Український ботанічний журнал, 2019, 76(6) пояснюється необхідністю швидких адаптацій до різкозмінних умов середовища та короткого періоду онтогенезу.

Аналіз видів адвентивних рослин у ценофлорах піонерних угруповань України за часом занесення виявив, що частки археофітів та кенофітів майже однакові - 49,5\% та 51,5\% відповідно (рис. 3). Загальне співвідношення між цими групами становить 1,0 : 1,02 і значно відрізняється від такого для неаборигенної флори України $(1,0: 4,5)$ (Protopopova et al., 2002). Така пропорція між мігрохроноелементами відображає специфічність процесу проникнення чужорідних видів у піонерні ценози. Попри те, що новоутворені місцезростання є досить сприятливим середовищем-реципієнтом i характеризуються вільним екологічним простором для появи і поширення нових видів, у т. ч. й адвентивних, різкозмінні, а подекуди й екстремальні абіотичні умови, в яких формуються угруповання піонерної рослинності, є лімітуючим фактором безперешкодного вселення та швидких адаптацій неаборигенів.

У розподілі між археофітами та кенофітами в межах окремих класів рослинності виявлені деякі відмінності. Зокрема, про активні процеси поповнення флористичного складу алохтонним компонентом свідчить значне переважання кенофітів (70\%) і незначний вміст археофітів (30\%) у ценозах Ammophiletea. Останні потерпають 
від багатьох антропогенних чинників, серед яких провідними $є$ рекреація та будівництво туристичних комплексів, що й зумовлюють занесення та розповсюдження видів чужорідних рослин. Натомість у класі Therosalicornietea, у спектрі якого помітно превалюють археофіти $(66,7 \%$, кенофіти - 33,3\%), вселення адвентів інтенсивно відбувалося в минулому. Також виявлено, що у ценозах Cakiletea maritimae (кенофіти $-53,8 \%$, археофіти $-46,2 \%$ ), Festucetea vaginatae $(51,3 \%$ та 48,7\%), Helichryso-Crucianelletea maritimae (55,3\% та 44,7\%) та Koelerio-Corynephoretea canescentis $(52,4 \%$ та 47,6\%), як і в загальному спектрі, зберігається невелике переважання кенофітів над археофітами. У класах Crypsietea aculeatae і Isoëto-Nanojuncetea ці групи рівновеликі, а незначна перевага археофітів характерна для угруповань абразивних пляжів і кліфів (CrithmoStaticetea) (археофіти - 60\%, кенофіти - 40\%), а також нітрифікованих перезволожених екотопів (Bidentetea) $(53,3 \% / 46,7 \%)$.

За ступенем натуралізації серед видів неаборигених рослин у піонерних угрупованнях України переважну більшість становлять епекофіти $(68,1 \%)$ (рис. 4). Майже однакову кількість у адвентивній фракції досліджених ценофлор мають агріо-епекофіти (10,6\%) та агріофіти $(9,7 \%)$. Найменш чисельними є групи нестабільних флористичних елементів - ергазіофітів $(5,3 \%)$ та ефемерофітів $(6,2 \%)$.

Подібний розподіл за ступенем натуралізації властивий більшості досліджених рослинних угруповань. Однак у ценозах Therosalicornetea, Crypsietea aculeatae та Crithmo-Staticetea діафіти відсутні. Це зумовлено специфічними умовами розвитку названих ценозів (зокрема, надмірне зволоження та/або засолення субстрату), шо суттєво обмежує вільне проникнення та подальшу натуралізацію адвентивних рослин.

Встановлено, що походження більшості видів адвентивних рослин піонерних угруповань України пов'язане з Древнім Середземномор'ям. Серед них 27,5\% мають середземноморськоірано-туранський, 24,8\% - середземноморський, $8,8 \%$ - ірано-туранський тип первинного ареалу (рис. 5). Відсоткові частки неаборигенів генетично поєднаних з північноамериканським та азійським флористичними центрами рівновеликі - по 15\%. У складі адвентивної фракції досліджених типологічних флор 7\% видів мають європейське походження. Належність до тієї чи іншої
Таблиця 4. Коефіцієнти Жаккара адвентивних фракцій ценофлор класів піонерної рослинності України

Table 4. Jaccard indices of coenofloras of the classes of pioneer vegetation in Ukraine

\begin{tabular}{|l|c|c|c|c|c|c|c|c|c|}
\hline & AMM & BID & CAK & CRI & CRY & FEV & CRU & COR & ISO \\
\hline BID & 0,09 & & & & & & & & \\
\hline CAK & 0,1 & 0,07 & & & & & & & \\
\hline CRI & 0,08 & 0,05 & 0,2 & & & & & & \\
\hline CRY & 0,07 & 0,1 & 0,19 & 0 & & & & & \\
\hline FEV & 0,08 & 0,07 & 0,06 & 0,04 & 0,08 & & & & \\
\hline CRU & 0,12 & 0,09 & 0,18 & 0,11 & 0,11 & 0,4 & & & \\
\hline COR & 0,12 & 0,13 & 0,03 & 0,07 & 0 & 0,13 & 0,08 & & \\
\hline ISO & 0,08 & 0,3 & 0,02 & 0,02 & 0,1 & 0,14 & 0,09 & 0,17 & \\
\hline THE & 0,17 & 0,07 & 0,13 & 0,16 & 0,2 & 0,1 & 0,13 & 0,06 & 0,17 \\
\hline
\end{tabular}

ареалогічної групи видів Descurainia sophia (L.) Webb ex Prantl та Capsella bursa-pastoris (L.) Medik. залишається невстановленою.

Таким чином, основним напрямком адвентизації угруповань піонерної рослинності України є формування здебільшого ксерофільних фітокомплексів та розширення флорогенетичних зв'язків із аридними територіями. Така тенденція властива для всіх досліджених класів, окрім Bidentetea, в якому переважають види північноамериканського походження. Представники цієї хорологічної групи тяжіють до більш мезофітних умов, характерних для ценозів названого класу.

Аналіз та порівняння безпосередньо видового складу неаборигенних компонент типологічних флор піонерних угруповань за допомогою коефіцієнта Жаккара виявили найбільшу якісну подібність відповідних спектрів екологічно близьких класів - Isoёto-Nanojuncetea та Bidentetea, а також Festucetea vaginatae та HelichrysoCrucianelletea maritimae (табл. 4). Проте багато спільних видів також відмічено і в угрупованнях, які відрізняються за умовами формування, що свідчить про високу екологічну пластичність та активні адаптивні стратегії видів адвентивних рослин.

Аналіз просторового розподілу та частоти трапляння видів адвентивної фракції досліджених ценофлор засвідчив, що найбільшу постійність у ценозах новоутворених екотопів мають Xanthium albinum (Widder) H.Scholz ta Conyza canadensis (L.) Cronq., які зафіксовані у шести із 10 класів піонерної рослинності України. В п'яти класах відмічені Atriplex prostrata Boucher ex DC., Anisantha sterilis (L.) Nevski, Senecio vulgaris L. i Cardaria 


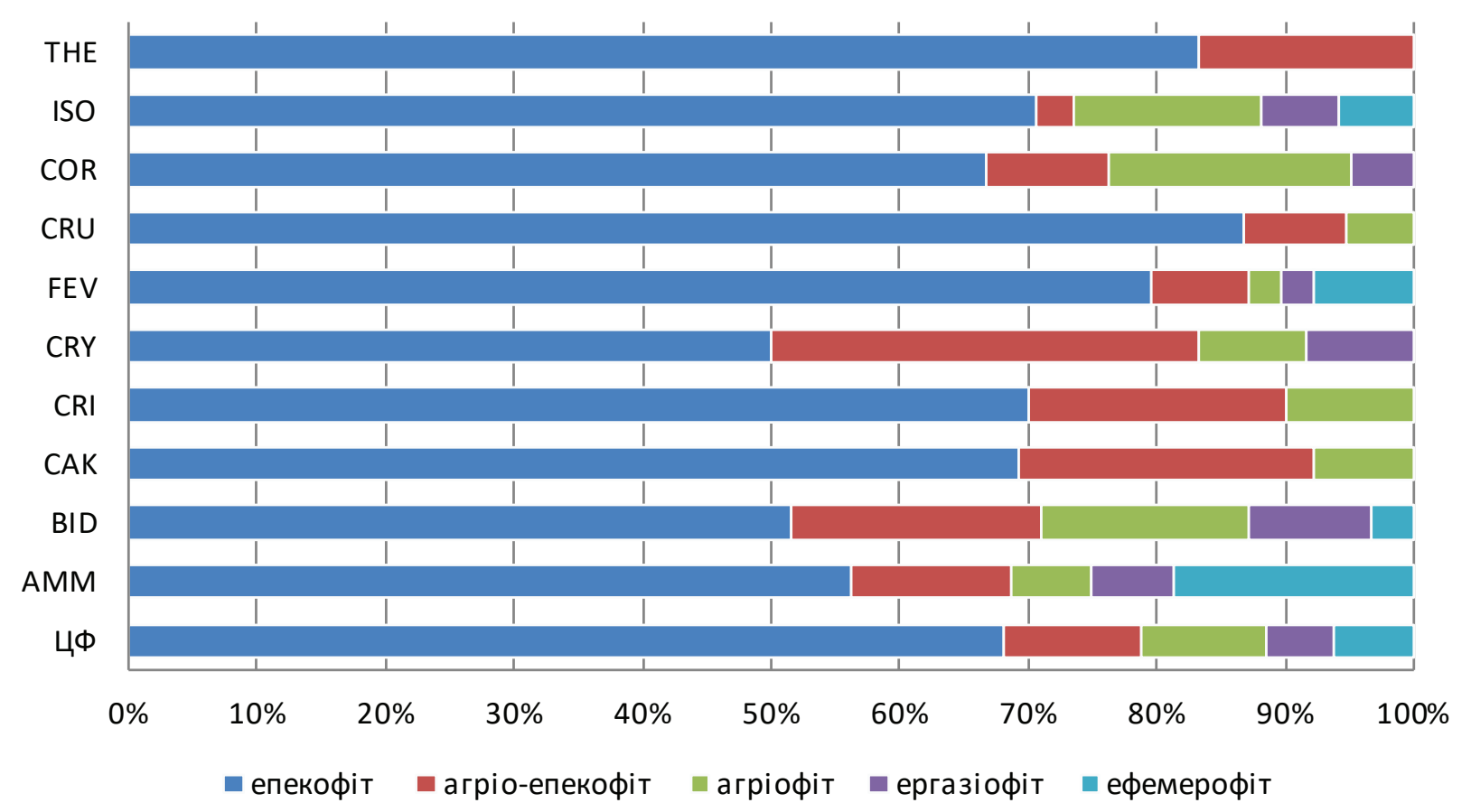

Рис. 4. Розподіл видів адвентивних рослин ценофлор класів піонерної рослинності України за ступенем натуралізації Fig. 4. Distribution of the species of alien plants of coenofloras of the classes of pioneer vegetation in Ukraine by naturalization degree

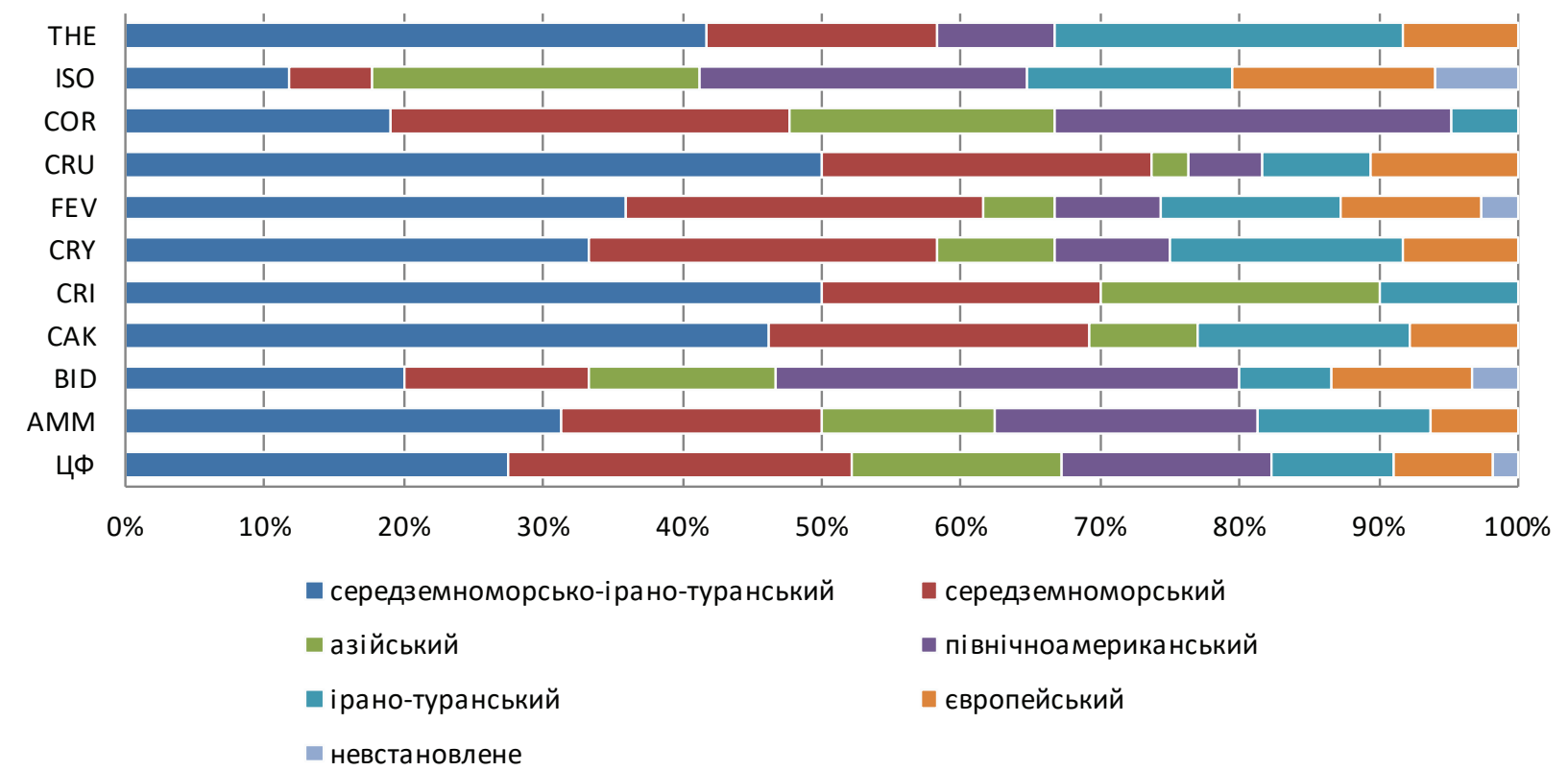

Рис. 5. Розподіл видів адвентивних рослин ценофлор класів піонерної рослинності України за походженням

Fig. 5. Distribution of the species of adventive plants of the coenofloras of the classes of pioneer vegetation in Ukraine by origin 


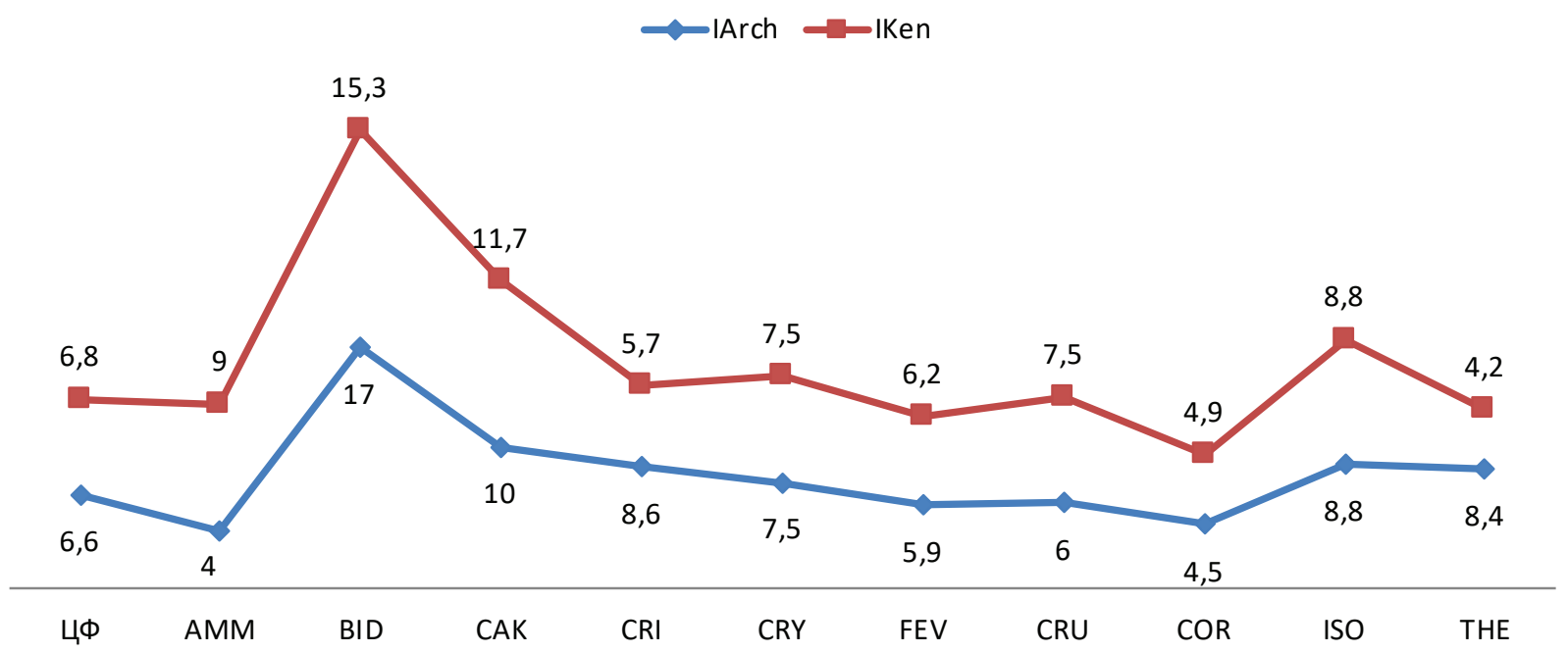

Рис. 6. Індекси археофітизації (IArch) та кенофітизації (IKen) у ценофлорах класів піонерної рослинності України

Fig. 6. Indices of archeophytization (IArch) and kenophytization (IKen) of coenofloras of the classes of pioneer vegetation in Ukraine

draba (L.) Desv., для чотирьох типовими є Bromus squarrosus L., Ambrosia artemisiifolia L., Echinochloa crusgalli (L.) P.Beauv., Erysimum repandum L., Kochia laniflora (S.G. Gmel.) Borbás, Anisantha tectorum (L.) Nevski та Cichorium intybus L. Одночасно 19 видів зафіксовані в угрупованнях трьох, а $31-$ у ценозах двох класів. Лише в одному класі трапляються 50 адвентивних видів.

Для визначення ступеня антропогенної трансформації ценофлор класів піонерної рослинності України використано показники археофітизації, кенофітизації, модернізації та нестабільності флори. Загальний індекс археофітизації досліджених ценофлор становить 6,6\%, а індекс кенофітизації - 6,8\% (рис. 6). На стійке вкорінення неаборигенних видів у флористичний склад відповідних угруповань вказують великі значення показника археофіти зації ценофлор класів Bidentetea (17\%) і Cakiletea maritimae (10\%). Високі індекси кенофітизації вже згаданих Bidentetea $(15,3 \%)$ і Cakiletea maritimae (11,7\%), а також Ammophiletea (9\%) свідчать про активні процеси занесення адвентивних рослин у сучасний період, а також поглиблення процесів трансформації флори цих угруповань під впливом новітніх антропогенних факторів. Загалом, неаборигенні види вже стали не лише стабільним елементом флористичної структури піонерних ценозів, але мають високу вірність і є діагностичними для багатьох синтаксонів різного ієрархічного рівня. Так, види адвентивних рослин $\epsilon$ сталим компонентом діагностичних блоків асоціацій Secali sylvestri-Brometum tectori, Anisantho tectorum-Helychrisetum arenarii, Anisantho tectorumMedicagetum kotovii, Myosoto aquatici-Bidentetum frondosae, Junco bufonii-Bidentetum connatae, Pulicario vulgaris-Menthetum pulegii та ін.

Загальний індекс модернізації ценофлор класів піонерної рослинності України становить 50,4\% (табл. 5). Клас Ammophiletea відзначається його найбільшим значенням (60\%), що підтверджує значні якісні зміни видового складу угруповань приморських піщаних дюн за рахунок еукенофітів, особливо із високою інвазійною спроможністю. Натомість специфічні екологічні умови ценозів абразивних пляжів і кліфів та періодично заливних солончаків є лімітуючим фактором інтенсивних інвазій у класах Therosalicornietea та Crithmo-

Таблиця 5. Індекси модернізації (IM) та нестабільності (IJ) ценофлор класів піонерної рослинності України Table 5. Indices of modernization (IM) and fluctuation (IJ) of coenofloras of the classes of pioneer vegetation in Ukraine

\begin{tabular}{|c|c|c|c|c|c|c|c|c|c|c|c|}
\hline Індекс & ЦФ & AMM & BID & CAK & CRI & CRY & FEV & CRU & $\mathrm{COR}$ & ISO & THE \\
\hline IM & 50,4 & 68 & 46,6 & 53,8 & 40 & 50 & 51,3 & 55,3 & 52,4 & 50 & 33,3 \\
\hline IJ & 1,5 & 3 & 4,3 & - & - & 8,3 & 1,2 & 5,2 & 0,4 & 2,1 & - \\
\hline
\end{tabular}


Таблиця 6. Матриця розподілу видів-трансформерів в угрупованнях піонерної рослинності України Table 6. Distribution matrix of transformers in plant communities of pioneer vegetation of Ukraine

\begin{tabular}{|c|c|c|c|c|c|c|c|c|c|c|}
\hline Вид & AMM & BID & CAK & CRI & CRY & FEV & $\mathrm{CRU}$ & $\mathrm{COR}$ & ISO & THE \\
\hline \multicolumn{11}{|l|}{ Ambrosia artemisiifolia } \\
\hline \multicolumn{11}{|l|}{ Amorpha fruticosa } \\
\hline \multicolumn{11}{|l|}{ Anisantha tectorum } \\
\hline \multicolumn{11}{|l|}{ Apera spica-venti } \\
\hline \multicolumn{11}{|l|}{ Bidens frondosa } \\
\hline \multicolumn{11}{|l|}{ Centaurea diffusa } \\
\hline \multicolumn{11}{|l|}{ Conyza canadensis } \\
\hline \multicolumn{11}{|l|}{ Echinocystis lobata } \\
\hline \multicolumn{11}{|l|}{ Elaeagnus angustifolia } \\
\hline \multicolumn{11}{|l|}{ Impatiens glandulifera } \\
\hline \multicolumn{11}{|l|}{ Solidago canadensis } \\
\hline Phalacroloma anпиит & & & & & & & & & & \\
\hline
\end{tabular}

Staticetea. Індекси модернізації тут найнижчі (33,3\% та $40 \%$ відповідно). Індекс нестабільності ценофлор класів піонерної рослинності України є невисоким $(1,5 \%)$. У різних класах його значення коливаються від 0,4\% (Koelerio-Corynephoretea canescentis) до 8,3\% (Crypsietea aculeatae). Флуктуаційні зміни флористичної структури не виявлені в класах Cakiletea maritimae, Therosalicornietea та CrithmoStaticetea.

Виділено інвазійне ядро адвентивної фракції досліджених ценофлор та проведено його аналіз. 3'ясовано, що найбільшою інвазійною спроможністю відзначається майже чверть усіх неаборигенів, виявлених у піонерних угрупованнях, 26 видів, які належать до 11 родин та 25 родів. Встановлено незначні відмінності у систематичній структурі інвазійних видів порівняно із адвентивною фракцією. Найчисельнішою залишається родина Asteraceae (12 видів або 42,3\%), на другому місці Poaceae $(3 ; 11,5 \%)$, на третьому Brassicaceae (2; 7,7\%), на четвертому Fabaceae $(2 ; 7,7 \%)$. Решта родин є одновидовими. Таким чином, систематичний спектр провідних родин інвазійного ядра зберігає основні риси адвентивної флори досліджених ценозів.

Розподіл за групами інвазійних мігрохроноелементів свідчить про посилення активних процесів проникнення адвентивних рослин останнім часом, чому сприяють збільшення інтенсивності впливу на ці угруповання та їхня низька антропотолерантність. Майже вдвічі переважають кенофіти (17 видів, 65,4\%), за ними археофіти (8, 34,6\%). За ступенем натуралізації більшість складають епекофіти (11, 42,3\%). Високою є участь агріо-епекофітів (9 видів, $34,6 \%$ ) та агріофітів (6, 23\%), шо є свідченням небезпечних тенденцій нині та збереження їх у майбутньому за посилення антропогенного навантаження. Оскільки, перші виявляють сталу активність щодо освоєння напівприродних місцезростань, а другі потенційно є найбільш небезпечними саме для природних угруповань. Найбільш вразливими до фітоінвазій виявилися угруповання класів Bidentetea, в яких зафіксовано 14 видів інвазійних рослин (53,8\% усіх виявлених у піонерних ценозах) та Isoëto-Nanojuncetea, в угрупованнях якого відмічено 13 таксонів (50\%) цієї групи.

Особливо загрозливим слід вважати те, що серед усіх видів інвазійних рослин досліджених ценофлор половина є трансформерами, які мають потужну інвазійну спроможність. Серед таких Amorpha fruticosa L., Ambrosia artemisiifolia, Anisantha tectorum, Apera spica-venti (L.) P.Beauv., Bidens frondosa L., Centaurea diffusa Lam., Conyza canadensis, Echinocystis lobata (Michx.) Torr. \& A.Gray, Elaeagnus angustifolia L., Impatiens glandulifera Royle, Solidago canadensis L. та Phalacroloma annuum (L.) Dumort. Ці види в угрупованнях піонерної рослинності, що мають і так послаблені ценотичні зв'язки, легко долають F-бар'єр, особливо за умови посилення антропогенного впливу. Найбільше трансформерів відмічено в ценозах Bidentetea (табл. 6), що пояснюється специфікою ценозів класу, які формуються на порушених рудералізованих добре зволожених нітрифікованих екотопах, які вкрай сприятливі для вселення та масового поширення рослин із підвищеною інвазійною спроможністю. За таких умов ці угруповання є потенційним джерелом загрози не лише для екологічно близьких ценозів, зокрема прибережно-водних, але й інших контактних, більш мезофітних. Також значну загрозу види трансформери становлять для 
вкрай вразливого й унікального наноефемеретуму (клас Isoёto-Nanojuncetea), оскільки змінюють не лише флористичний склад та ценотичну структуру цих угруповань, а й здатні перетворювати умови середовища за рахунок збагачення грунту сполуками азоту або споживання значної кількості водних ресурсів.

У цілому види-трансформери в угрупованнях піонерної рослинності складають потужну конкуренцію аборигенним видам, здійснюючи різні впливи за ступенем і характером. Вони здатні погіршувати життєвість популяцій місцевих видів, пригнічуючи їхній ріст, розвиток, відтворення, стійкість та знижуючи щільність. Небезпечною є потенційна загроза гібридизації із аборигенними видами, особливо тими, що $є$ діагностичними у синтаксонах різного рангу класифікації i що призводить до локального зникнення представників місцевої флори та незворотних змін у складі рослинних угруповань.

\section{Висновки}

Адвентивну фракцію ценофлор класів піонерної рослинності України складають 113 видів вищих судинних рослин з 88 родів та 32 родин. Найменш стійкими серед ценозів новоутворених місцезростань $є$ угруповання пішаних та галькових морських узбереж (Cakiletea maritimae), низькорослих терофітів, що зростають в умовах періодичної різкої зміни зволоження (IsoёtoNanojuncetea), а також рудералізовані нітрифіковані ценози, які поширені біля водойм та водотоків (Bidentetea).

У складі адвентивної фракції значна питома вага належить видам із високим ступенем натуралізації та потужною інвазійною спроможністю. Виявлено 12 видів-трансформерів, які $€$ загрозою для флористичного різноманіття та фітоценотичного багатства цього унікального і водночас вразливого типу рослинності.

У зв'язку з інтенсивним поширенням видів адвентивних рослин, особливо із високим інвазійним потенціалом, актуальним є комплекс заходів, спрямованих на мінімізацію їхнього впливу. Серед них першочерговим є організація екологічного комп'ютеризованого моніторингу за появою та поширенням адвентивних рослин, а також реалізація відповідних, насамперед превентивних заходів, спрямованих на запобігання масовим інвазіям неаборигенних видів у піонерні та контактні з ними фітоценози. Ці завдання мають стати невід'ємною частиною стратегії збереження піонерної рослинності як особливого та унікального типу.

\section{СПИСОК ПОСИЛАНЬ}

Dubyna D.V., Dvoretskyi T.V., Dzyuba T.P., Tymoshenko P.A. 2016a. Chornomorskyi Botanical Journal, 12(2): 107-123. [Дубина Д.В., Дворецький Т.В., Дзюба Т.П., Тимошенко П.А. 2016а. Біоморфологічна структура ценофлор піонерної рослинності України. Чорноморський ботанічний журнал, 12(2): 107-123].

Dubyna D.V., Dzyuba T.P., Iemelyanova S.M., Davydov D.A. 2016b. Ukrainian Botanical Journal, 73(1): 11-20. [Дубина Д.В., Дзюба Т.П., Ємельянова С.М., Давидов Д.А. 2016b. Сучасний стан та актуальні завдання охорони піонерної рослинності України. Український ботанічний журнал, 73(1): 11-20].

Dubyna D.V., Dvoretskyi T.V., Iemelyanova S.M., Dzyuba T.P., Tymoshenko P.A. 2017. Ukrainian Botanical Journal, 74(5): 421-430. [Дубина Д.В., Дворецький Т.В.,Ємельянова С.М., Дзюба Т.П., Тимошенко П.А. 2017. Систематична структура ценофлор класів піонерної рослинності України. Український ботанічний журнал, 74(5): 421-430]. https://doi. org/10.15407/ukrbotj74.05.421

Jackowiak B. 1990. Antropogeniczne przemiany flory roslin naczyniowych Poznania. Poznan: Wydawnictwo Naukowe Unuwersytetu Adama Mickiewicza, $232 \mathrm{~s}$.

Kornaś J. 1968. A geographical-historical classification of synanthropic plants. Materialy Zakladu Fitosocjologii Stosowanej Uniwersitetu Warszawskiego, 25: 33-41.

Mosyakin S.L., Fedoronchuk M.M. 1999. Vascular plants of Ukraine. A nomenclatural checklist. Kiev, 345 pp. + xxiii.

Mucina L., Bültmann ${ }_{S}$ H., Dierßen K., Theurillat J.-P., Raus T., Čarni A., Sumberová K., Willner W., Dengler J., Gavilán García R., Chytrý M., Hájek M., Di Pietro R., Iakushenko D., Pallas J., Daniëls F.J.A., Bergmeier E., Santos Guerra A., Ermakov N., Valachovič M., Schaminée J.H.J., Lysenko T., Didukh Y.P., Pignatti S., Rodwell J.S., Capelo J., Weber H.E., Solomeshch A., Dimopoulos P., Aguiar C., Hennekens S.M., Tichý L. 2016. Vegetation of Europe: hierarchical floristic classification system of vascular plant, bryophyte, lichen, and algal communities. Applied Vegetation Science, 19(1): $1-783$.

Protopopova V.V. 1991. Sinantropnaya flora Ukrainy i puti ee razvitiya. Kiev: Naukova Dumka, 204 pp. [Протопопова В.В. 1991. Синантропная флора Украины и пути ее развития. Киев: Наукова думка, 204 с.].

Protopopova V.V., Mosyakin S.L., Shevera M.V. 2002. Fitoinvazii v Ukraini yak zahroza bioriznomanittyu: suchasnyi stan i zavdannya na maybutnye. Kyiv, 32 pp. [Протопопова В.В., Мосякін С.Л., Шевера М.В. 2002. Фітоінвазії в Україні як загроза біорізноманіттю: сучасний стан і завдання на майбутне. Київ, 32 с.].

Shmidt V.M. 1980. Statisticheskie metody v sravnitelnoy floristike. Leningrad: Nauka, 176 pp. [Шмидт B.M. 1980. Статистические методы в сравнительной флористике. Ленинград: Наука, 176 с.].

Tolmachev A.I. 1974. Vvedenie v geografiju rastenij. Leningrad: Izd-vo Leningrad. Univ., 244 рр. [Толмачев А.И. 1974. Введение в географию растений. Ленинград: Изд-во Ленинград. ун-та, 244 с.].

Рекомендує до друку М.В. Шевера 


\title{
Угруповання класу Festuco-Brometea природного заповідника "Еланецький степ"
}

\author{
Валерія О. КОНАЙКОВА
}

Інститут ботаніки ім. М.Г. Холодного НАН України

вул. Терещенківська 2, Київ 01004, Україна

konaykova@ukr.net

Konaikova V.O. 2019. Communities of the class Festuco-Brometea in Yelanetskyi Step Nature Reserve. Ukrainian Botanical Journal, 76(6): 511-525.

M.G. Kholodny Institute of Botany, National Academy of Sciencies of Ukraine

2 Tereshchenkivska Str., Kyiv 01004, Ukraine

Absract. The article provides characteristics of the steppe vegetation of the class Festuco-Brometea within Yelanetskyi Step Nature Reserve. A history of geobotanical studies of this territory is briefly outlined. In total, vegetation of the class belongs to two orders, three alliances, six associations, and one variant. Communities of the alliance Festucion valesiacae in the reserve are represented by sod-cereal steppes and include one association and one variant. Communities of this alliance are formed in the areas that are exposed to anthropogenic factors; most often they are located on abandoned lands or areas under moderate grazing on the planes. Communities of the alliance Stipion lessingianae grow on black soils (chernozem) but with some inclusion of limestone. This alliance includes three associations which occupy ravine slopes of various steepness and exposure. The alliance Potentillo arenarie-Linion czerniaevii is represented by the communities on the limestone outcrops. It was established that the last two alliances demonstrate higher floristic diversity, which can be explained by differentiation of syntaxa within the area. The communities of these alliances include species from the European Red List and the IUCN Red List. Species listed in the Red Data Book of Ukraine are present in all syntaxa. A number of threats for the steppe communities on the study area have been identified.

Keywords: classification, Festuco-Brometea, nature reserve, steppe, syntaxonomy

Submitted 13 September 2019. Published 29 December 2019

Конайкова В.О. 2019. Угруповання класу Festuco-Brometea природного заповідника "Сланецький степ". Український ботанічний журнал, 76(6): 511-525.

Реферат. У статті наведено характеристику степової рослинності класу Festuco-Brometea в межах природного заповідника "Єланецький степ". Коротко описано історію геоботанічних досліджень території. Для досліджуваної території наводиться шість асоціацій та один варіант асоціації, що належать до двох порядків, трьох союзів. Угруповання союзу Festucion valesiacae на території заповідника є дернинно-злаковими степами, представлені однією асоціацією та одним варіантом; формуються на ділянках, що піддавалися антропогенному впливу, найчастіше це перелоги або місця помірного випасу; поширені на приплакорних ділянках. Асоціації союзу Stipion lessingianae в умовах природного заповідника займають схили балок різної крутизни та експозиції; до союзу належать три асоціації. Союз Potentillo arenarie-Linion czerniaevii представлений угрупованнями, розташованими на виходах вапняку. Встановлено, що останні два союзи є флористично різноманітнішими, що пояснюється територіальною диференціацією синтаксонів. До складу угруповань цих союзів входять види, включені до Європейського Червоного списку та списку Міжнародного союзу охорони природи. Види, що внесені до Червоної книги України, наявні в усіх синтаксонах. Встановлено ряд загроз для степових ценозів на території дослідження.

Ключові слова: класифікація, природний заповідник, синтаксономія, степ, Festuco-Brometea

(C) 2019 V.O. Konaikova. Published by the M.G. Kholodny Institute of Botany, NAS of Ukraine. This is an open access article under the terms of the Creative Commons Attribution License (http://creativecommons.org/licenses/by/4.0/), which permits use, distribution, and reproduction in any medium, provided the original work is properly cited 


\section{Вступ}

На сьогодні, за умов постійного антропогенного навантаження й масштабного розорювання, степи $€$ екосистемою, що знаходиться на межі зникнення. Для збереження залишків цілинних степів та відновлення вже порушених ділянок велике значення мають заповідники, що є осередками раритетних природних видів рослин Степової зони. Одним з таких є заповідник "Еланецький степ", створений в 1996 р. (площа 1657,7 га) та розширений в 2016 р. за рахунок приєднання ландшафтного заказника "Михайлівський степ" (площа 1334,95 га). Нині заповідник складається 3 двох відділень: Єланецького та Михайлівського. У заповіднику представлені типові угруповання різнотравно-злакових степів Правобережної України, які ми і досліджували в даній роботі.

Вперше комплексне обстеження нерозширеного заповідника було здійснене О.В. Костильовим, який описав сім найбільших за площею формацій степової рослинності (Kostyliov, 1987). Після створення заповідника у 1996 р. детальні дослідження провів В.С. Ткаченко, який проаналізував 17 найбільших за площею формацій та описав структурні та екологічні зміни в рослинності заповідника за перші 10 років його існування (Tkachenko, Sirotenko, 1999; Tkachenko, Ostrivna, 2006; Tkachenko, 2009). У публікаціях О.М. Деркача (Derkach 2005, 2011) згадується про 13 формацій степової рослинності ландшафтного заказника "Михайлівський степ".

У даній роботі представлено характеристику степової рослинності класу Festuco-Brometea Br.-B1. et Тx. 1943 на основі підходу Браун-Бланке (BraunBlanquet, 1964). В межах природного заповідника геоботанічні дослідження даної території грунтувалися на домінантній системі, лише еколого-ценотичні особливості виду Scutellaria verna Besser (Moysiyenko et al., 2005) були визначені за еколого-флористичною методикою.

\section{Матеріали та методи}

Були проаналізовані власні описи степової рослинності, виконані нами впродовж травнячервня 2017-2018 рр. у заповіднику "Сланецький степ". Згідно із методикою еколого-флористичного підходу Ж. Браун-Бланке (Braun-Blanquet, 1964), зроблено 218 описів степової рослинності 3

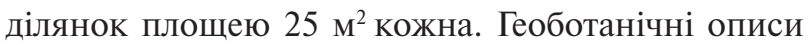

були внесені до бази даних TURBOVEG 2.90 (Hennekens, Schaminée, 2001) та оброблені за допомогою програмного забезпечення JUICE 7.0.45 (Tichý, 2002). Виділення кластерів, шо відповідали синтаксонам, проводилося 3 використанням прикладної програми TWINSPAN Modified (Hill, 1979; Roleček, Tichý, Zelený, Chytrý, 2009). Діагностичними видами вважалися види зі значенням phi $\geq 0,3$, високодіагностичними - зі значенням phi $\geq 0,5$. Домінантними видами вважали види із проективним покриттям понад $30 \%$ у травостої. Для визначення отриманих синтаксонів було зроблено порівняння 3 опублікованими синтаксонами (Korotchenko, Didukh, 1997; Krasova, Smetana, 1999; Didukh, Korotchenko, 2003; Korotchenko et al., 2009a, b; Kutyna et al., 2011; Didukh, Vashenyak, 2012; Didukh, Chusova, 2014; Vynokurov, 2014a, b, 2016).

Для синтаксономічних таблиць проективне покриття видів переведене в бали за наступною шкалою: $1-\leq 1 \% ; 2-2-5 \% ; 3-6-20 \%$; $4-21-$ $50 \% ; 5->50 \%$ (Mirkin et al., 1989).

Синтаксони вищого рангу (клас, порядок, союз) прийняті за європейською класифікацією рослинності (Mucina et al., 2016). Латинські назви видів подано за таксономічним зведенням (Mosiakin, Fedoronchuk, 1999).

Фізико-географічні особливості території. Досліджувана територія заповідника "Еланецький степ" за фізико-географічним районуванням належить до Степової зони, Дністровсько-Дніпровського краю, Південно-Придніпровської схилововисочинної області (Fiziko-geograficheskoe..., 1968). За геоботанічним районуванням - до Євразійськостепової області, Понтичної степової провінції, Чорноморсько-Азовської підпровінції, БузькоДніпровського округу різнотравно-злакових степів, байрачних лісів та рослинності гранітних відслонень, Новобузько-Вознесенського геоботанічного району (Didukh, Shelyag-Sosonko, 2003).

Територія заповідника являє собою яружнобалкову систему (балки Прусакова, Роза, та Орлова - Єланецьке відділення; балки Кемлича, Великадівчина - Михайлівське). Рельєф місцевості слабкохвилястий, характеризується наявністю балок та ярів, кам'янистих схилів з відслоненнями понтичних вапняків, які на окремих ділянках утворюють карнизи, тераси або кам'яні розсипи (Kolomiychuk et al., 2012). 
Клімат території заповідника помірноконтинентальний із середньорічною температурою $+12,3{ }^{\circ} \mathrm{C}$. Середня температура січня складає від -4 до $-4,5{ }^{\circ} \mathrm{C}$, липня - від +22 до $+22,5{ }^{\circ} \mathrm{C}$. Абсолютна максимальна температура в липні $+39^{\circ} \mathrm{C}$, мінімальна в січні до $-30{ }^{\circ} \mathrm{C}$. Тривалість безморозного періоду становить 170-200 діб, кількість опадів - 360-410 мм на рік. На період з квітня до жовтня припадає 70\% загальної щорічної кількості опадів.

Грунтовий покрив на плакорних ділянках утворений переважно звичайними малогумусними чорноземами, середньо та сильно змитими на схилах, часто із виходами вапняків на поверхні (Грунти..., 1969).

\section{Результати та обговорення}

У статті аналізуються угруповання класу FestucoBrometea. За результатами аналізу геоботанічних описів наводимо класифікаційну схему рослинності. Синоптична таблиця синтаксонів класу Festuco-Brometea наведена в табл. 1.

Cl. Festuco-Brometea Br.-B1. \& Tx. 1943

Ord. Festucetalia valesiacae Soó 1947

All. Festucion valesiacae Klika 1931

Ass. Potentillo arenariae-Stipetum capillatae (Hueck 1931) Krausch 1961

Ass. Salvio nemorosae-Festucetum valesiacae Korotchenko \& Didukh 1997 var. Botriochloetum ischaemii

All. Stipion lessingianae Soo 1947

Ass. Vinco herbaceae-Caraganetum fruticis Korotchenko \& Didukh 1997

Ass. Stipo lessingianae-Salvietum nutantis Vynokurov 2014

Ass. Plantagini stepposae-Stipetum pulcherrimae Solomakha 1995

Ord. Stipo pulcherrimae-Festucetalia palentis Pop 1968 All. Potentillo arenarie-Linion czerniaevii Krasova \& Smetana 1999

Ass. Lino tenuifolii-Jurineetum brachycephalae Krasova \& Smetana 1999

Ass. Cleistogenetum bulgaricae Krasova 1999

До класу Festuco-Brometea увійшли угруповання із домінуванням дернинних злаків Stipa lessingiana Trin. \& Rupr., S. capillata L., S. pulcherrima K.Koch, $S$. ucrainica P.A.Smirn., Festuca valesiaca Gaudin, F. rupicola Heuff. та коротокореневищних злаків
Botriochloa ischaemum (L.) Keng, Poa angustifolia L., a також фітоценози вапнякових відслонень.

Угруповання союзу Festucion valesiacae на території заповідника є дернинно-злаковими степами. Формуються на ділянках, що піддавалися антропогенному впливу, найчастіше це перелоги або місця помірного випасу. Поширені на приплакорних ділянках балок або на пологих схилах. Союз представлений 1 асоціацією та 1 варіантом (табл. 2).

Асоціація Potentillo arenariae-Stipetum capillatae

Діагностичні види: Achillea pannonica Scheele, Astragalus ucrainicus M.Pop. \& Klokov, Bothriochloa ischaemum, Koeleria cristata (L.) Pers., Festuca rupicola, Potentilla incana P.Gaertn., B.Mey. \& Scherb, Stipa capillata $\mathrm{L}$.

Константні види: Agropyron pectinatum (M.Bieb.) P.Beauv., Astragalus austriacus Jacq., Bothriochloa ischaemum, Caragana frutex (L.) K.Koch, Euphorbia sequierana Neck., E. stepposa Zoz ex Prokh., Falcaria vulgaris Bernh., Festuca valesiaca, Hypericum elegans Stephan ex Willd., Marrubium praecox Janka, Phlomis pungens Willd., Salvia nemorosa L., S. nutans L., Senecio vernalis Waldst. \& Kit., Teucrium polium L., Convolvulus arvensis L., Securigera varia (L.) Lassen, Seseli campestre Besser, Stipa lessingiana Trin. \& Rupr.

Домінантні види: Bothriochloa ischaemum, Festuca rupicola, Festuca valesiaca, Salvia nemorosa, Stipa capillata.

Угруповання асоціації є стадією відновлення перелогів 15-20 річного віку, або формуються в умовах помірного випасу худоби (на території Михайлівського відділення) і приурочені до приплакорних некрутих (2-5) схилів північної, східної, західної експозицій. Рослинний покрив добре сформований, має проективне покриття 8095\%, покриття підстилки 10-30\%. Кількість видів в описі 24-30.

Асоціація Salvio nemorosae-Festucetum valesiacae var. Botriochloetum ischaemii

Діагностичні види: Adonis vernalis L., Medicago falcata L., Salvia nemorosa, S. nutans, Senecio jacobaea L., Viola ambigua Waldst. \& Kit.

Константні види: Achillea pannonica, Astragalus austriacus, Convolvulus arvensis, Inula oculus-christi L., Marrubium praecox, Seseli campestre, Stachys recta L., Stipa lessingiana, Teucrium polium L., Thymus dimorphus Klokov \& Des.-Shost., Viola ambigua. 
Домінантні види: Bothriochloa ischaemum, Festuca valesiaca, Salvia nemorosa.

Угруповання асоціації формуються на ділянках, що зазнали впливу діяльності людини; часто вони є стадією відновлення степової рослинності після пожежі або випасу. Займають незначні площі на некрутих схилах верхніх та середніх частин балок східної та північної експозицій. Кількість в описі видів 23-27.

Угруповання союзу Stipion lessingianae зростають на чорноземах із вмістом вапняку. В умовах природного заповідника займають схили балок різної крутизни та експозиції. Представлений трьома асоціаціями (табл. 3).

Асоціація Vinco herbaceae-Caraganetum fruticis

Діагностичні види: Achillea pannonica, Adonis vernalis, Caragana frutex, Chamaecytisus graniticus (Rehmann) Rothm., Clematis integrifolia L., Hypericum elegans, Inula oculus-christi L., Vinca herbacea Waldst. $\&$ Kit.

Константні види: Astragalus austriacus, A. ucrainicus, Bothriochloa ischaemum, Falcaria vulgaris Bernh., Festuca valesiaca, Galium octonarium (Klokov) Soó, Hypericum elegans, Inula oculus-christi, Medicago falcata, Phlomis pungens, Salvia nutans, Stachys recta, Stipa capillata, S. lessingiana, S. ucrainica, Tanacetum millefolium (L.) Tzvelev, Teucrium chamaedrys L., T. polium L., Thalictrum minus L., Thymus dimorphus, Viola ambigua.

Домінантні види: Caragana frutex, Chamaecytisus graniticus, Stipa lessingiana.

Угруповання спорадично трапляються на території заповідника на середній частині схилів помірної крутизни $\left(5-10^{\circ}\right)$. Поширені переважно в Єланецькому відділенні заповідника. Покриття підстилки - до 5\%.

Асоціація Stipo lessingianae-Salvietum nutantis

Діагностичні види: Astragalus austriacus, Galatella villosa (L.) Rchb.f., Helichrysum arenarium (L.) Moench, Inula oculus-christi, Linum hirsutum L., Nepeta parviflora M.Bieb., Plantago urvillei Opiz, Sideritis montana L., Salvia nutans, Stipa lessingiana, Tanacetum millefolium.

Константні види: Achillea pannonica, Adonis vernalis, Agropyron pectinatum, Astragalus dasyanthus Pall., Bromopsis inermis (Leyss.) Holub, Campanula sibirica L., Caragana frutex, Convolvulus lineatus L., Festuca valesiaca, Iris pumila L., Jurinea arachnoidea Bunge, Linum austriacum L., L.tenuifolium L., Phlomis pungens, Ph.tuberosa L., Plantago urvillei, Potentilla astracanica Jacq., Stachys recta, Teucrium chamaedrys, T. polium, Thalictrum minus, Thymus dimorphus, Veronica austriaca, Viola ambigua .

Домінантні види: Galatella villosa, Stipa lessingiana, S. ucrainica.

Угруповання асоціації поширені по всій території заповідника на схилах різної експозиції. У Михайлівському відділенні займають до $25 \%$ від загальної площі. Видовий склад ценозів є одним 3 найбагатших з усіх синтаксонів класу, серед степового різнотрав'я переважають види роду Astragalus. Угруповання цієї асоціації найменш порушені випасом та агродіяльністю людини. В складі грунту в незначній кількості (до 5\%) може бути присутній вапняковий дрібнозем.

\section{Асоціація Plantagini stepposae-Stipetum}

\section{pulcherrimae}

Діагностичні види: Astragalus austriacus, A.onobrychis L., Ephedra distachya L., Medicago falcata, Stipa lessingiana, S. pulcherrima.

Константні види: Achillea pannonica, Adonis vernalis, Astragalus onobrychis L., Eryngium campestre L., Euphorbia sequierana, E. stepposa, Festuca valesiaca, Haplophyllum suaveolens (DC) G.Don f., Medicago falcata, Phlomis pungens, Reseda lutea L., Salvia nemorosa, S. nutans, Securigera varia, Seseli campestre, Stachys recta, Stipa capillata, S. lessingiana, S. pulcherrima, S. ucrainica, Teucrium chamaedrys, T. polium, Thalictrum minus, Thymus dimorphus, Verbascum lychnitis.

Домінантні види: Festuca valesiaca, Stipa lessingiana, S. pulcherrima.

Асоціація представляє найкраще збережені ділянки степової рослинності. Покриття підстилки становить 15-30\%. Також характерний вміст вапнякового дрібнозему (2-5\%).

Сою3 Potentillo arenarie-Linion czerniaevii представлений угрупованнями, що зростають на виходах вапняку. На території заповідника "Еланецький степ" вапнякові відслонення переважно приурочені до нижніх частин схилів балок. Для союзу ми наводимо дві асоціації (табл. 4).

Асоціація Lino tenuifolii-Jurineetum brachycephalae Діагностичні види: Astragalus albidus Waldst. \& Kit., Centaurea marschalliana Spreng., Convolvulus lineatus, Genista scythica Pacz., Jurinea brachycephala 
Таблиця 1. Синоптична таблиця синтаксонів класу Festuco-Brometea (у відсотках, за вірністю - phi-коефіцієнтом) Table 1. Synoptic table of syntaxa of the class Festuco-Brometea (percentage, with fidelity - phicoefficient)

\begin{tabular}{|c|c|c|c|c|c|c|c|}
\hline Номер синтаксону & 1 & 2 & 3 & 4 & 6 & 7 & 8 \\
\hline Кількість описів & 10 & 11 & 8 & 8 & 8 & 10 & 10 \\
\hline Festuca rupicola & 60.7 & 2.5 & - & - & 13.7 & - & - \\
\hline Stipa capillata & 48.5 & - & - & 0.3 & 15.7 & 8 & - \\
\hline $\begin{array}{l}\text { Bothriochloa } \\
\text { ischaemum }\end{array}$ & 42.7 & 8 & 12.1 & - & - & - & 12.1 \\
\hline Clypeola jonthlaspi & 42.4 & - & - & - & - & - & - \\
\hline Anagallis caerulea & 42.4 & - & - & - & - & - & - \\
\hline Koeleria cristata & 37.8 & - & 12.6 & - & - & 12.6 & - \\
\hline Achillea pannonica & 35.8 & 1.4 & 35.8 & - & 5.5 & - & - \\
\hline Poa angustifolia & 31.7 & - & - & - & - & 11.5 & - \\
\hline Stipa lessingiana & 30 & 1.1 & - & 20.4 & 20.4 & - & - \\
\hline $\begin{array}{l}\text { Tanacetum } \\
\text { achilleifolium }\end{array}$ & 30 & - & - & - & - & - & - \\
\hline Salvia nemorosa & - & 47.1 & - & 13.7 & - & - & - \\
\hline Agrimonia eupatoria & - & 40.3 & - & - & - & - & - \\
\hline $\begin{array}{l}\text { Chamaecytisus } \\
\text { skrobiszewskii }\end{array}$ & - & - & 90 & - & - & - & 5.3 \\
\hline Astragalus ucrainicus & 4 & - & 65.6 & - & - & - & - \\
\hline Vinca herbacea & - & - & 67.7 & - & 14.4 & - & - \\
\hline Oxytropis pilosa & - & - & 60.7 & - & - & - & - \\
\hline Clematis integrifolia & - & - & 51.1 & - & - & 18 & - \\
\hline Plantago stepposa & - & - & 50.3 & - & 14.7 & - & - \\
\hline Adonis vernalis & 0.3 & - & 46.6 & 0.3 & 0.3 & 0.3 & - \\
\hline Caragana frutex & 0.3 & - & 46.6 & 0.3 & 31.2 & - & - \\
\hline Jurinea arachnoidea & - & - & 42.9 & 26.2 & 9.5 & - & 1.1 \\
\hline Thalictrum minus & - & - & 45.7 & - & 30.4 & - & - \\
\hline Astragalus albicaulis & - & - & 42.4 & - & - & - & - \\
\hline Herniaria glabra & - & - & 42.4 & - & - & - & - \\
\hline Hypericum elegans & 20.7 & - & 40.1 & - & - & - & 11 \\
\hline Teucrium chamaedrys & 2.3 & - & 40.2 & 25 & - & - & - \\
\hline Astragalus onobrychis & - & - & - & 68.2 & - & 5.8 & - \\
\hline $\begin{array}{l}\text { Verbascum } \\
\text { phoeniceum }\end{array}$ & - & 4.7 & - & 53.3 & - & - & - \\
\hline Brassica cretica & - & 19.9 & - & 50.9 & - & - & - \\
\hline Viola kitaibeliana & - & - & - & 46.6 & 17.9 & - & - \\
\hline Medicago falcata & - & 19.4 & 3 & 43.2 & - & - & - \\
\hline Asparagus officinalis & - & - & - & 42.4 & - & - & - \\
\hline $\begin{array}{l}\text { Haplophyllum } \\
\text { suaveolens }\end{array}$ & 2.8 & 1 & - & 42.9 & - & 2.8 & - \\
\hline Ephedra distachya & - & - & - & 38.1 & 12.8 & - & 0.1 \\
\hline Stipa pulcherrima & - & 4.6 & 7.5 & 40.3 & - & - & 15.7 \\
\hline Stachys transsilvanica & - & 9.8 & 13.9 & 30 & 13.9 & - & - \\
\hline Ajuga chia & - & - & - & 30 & - & 29 & - \\
\hline Linum hirsutum & - & - & - & - & 82.4 & - & - \\
\hline
\end{tabular}

\begin{tabular}{|l|c|c|c|c|c|c|c|}
\hline Номер синтаксону & 1 & 2 & 3 & 4 & 6 & 7 & 8 \\
\hline Кількість описів & 10 & 11 & 8 & 8 & 8 & 10 & 10 \\
\hline $\begin{array}{l}\text { Tanacetum } \\
\text { millefolium }\end{array}$ & - & - & - & - & $\mathbf{6 7 . 1}$ & 4.6 & - \\
\hline Nepeta parviflora & - & - & - & - & $\mathbf{5 8 . 7}$ & - & - \\
\hline Crinitaria villosa & - & 3.5 & 22.6 & - & $\mathbf{5 5}$ & - & - \\
\hline Veronica austriaca & - & - & - & - & $\mathbf{5 2 . 2}$ & - & - \\
\hline Veronica spicata & - & - & - & - & $\mathbf{4 2 . 4}$ & - & - \\
\hline Inula oculus-christi & 6.2 & - & 13.8 & - & $\mathbf{4 4 . 5}$ & - & - \\
\hline Phlomis tuberosa & - & 11.1 & - & - & $\mathbf{3 9 . 2}$ & - & - \\
\hline Stipa ucrainica & - & 5.7 & 25.4 & - & $\mathbf{4 1 . 9}$ & - & - \\
\hline Crambe tataria & - & - & - & - & $\mathbf{3 2 . 3}$ & 12.4 & - \\
\hline Linaria biebersteinii & - & - & - & - & $\mathbf{3 2 . 3}$ & 12.4 & - \\
\hline Cleistogenes bulgarica & - & - & - & - & - & $\mathbf{8 4 . 1}$ & - \\
\hline Paronychia cephalotes & - & - & - & - & - & $\mathbf{6 8 . 3}$ & - \\
\hline Alyssum tortuosum & - & - & - & - & - & $\mathbf{4 3 . 4}$ & 8.7 \\
\hline Koeleria lobata & - & - & - & - & - & $\mathbf{3 7 . 1}$ & 21.5 \\
\hline Reseda lutea & - & - & 5.3 & 5.3 & - & $\mathbf{3 7}$ & 15.9 \\
\hline Artemisia austriaca & 4.2 & 2.3 & - & 4.2 & - & $\mathbf{3 5 . 2}$ & - \\
\hline Potentilla pilosa & - & 16.2 & - & - & - & $\mathbf{3 3 . 5}$ & - \\
\hline Cephalaria uralensis & - & - & - & - & - & $\mathbf{3 2 . 3}$ & 12.4 \\
\hline Minuartia leiosperma & - & - & - & - & - & 29.8 & - \\
\hline Chondrilla juncea & - & - & - & - & - & 29.8 & - \\
\hline $\begin{array}{l}\text { Jurinea } \\
\text { brachycephala }\end{array}$ & - & - & - & - & - & - & $\mathbf{8 8 . 2}$ \\
\hline Genista scythica & - & - & - & - & - & 25.2 & $\mathbf{5 0 . 4}$ \\
\hline Linum tenuifolium & - & - & - & - & 5.3 & 15.9 & $\mathbf{4 7 . 6}$ \\
\hline Euphorbia sequierana & 21.2 & - & - & 21.2 & - & 13.2 & $\mathbf{3 7 . 2}$ \\
\hline Linum czerniaevii & - & - & - & - & - & - & $\mathbf{3 0 . 8}$ \\
\hline Carex praecox & - & - & 5.3 & - & - & - & - \\
\hline Poa angustifolia & 9.8 & - & - & - & - & - & - \\
\hline Elytrigia repens & - & 8 & - & - & - & - & - \\
\hline Lactuca serriola & - & - & - & 11.4 & - & 11.4 & - \\
\hline Convolvulus arvensis & 19.5 & 14.7 & - & 11.9 & - & - & - \\
\hline Carduиs thoermeri & 4.2 & - & - & - & 18.8 & - & - \\
\hline & & & & - & & & - \\
\hline
\end{tabular}

Цифрами позначені синтаксони (The numbers marked syntaxa): 1 - Potentillo arenariae-Stipetum capillatae; 2 Salvio nemorosae-Festucetum valesiacae var. Botriochloetum ischaemii; 3 - Vinco herbaceae-Caraganetum fruticis; 4 - Plantagini stepposae-Stipetum pulcherrimae; 5 - Stipo lessingianae-Salvietum nutantis; 6 - Cleistogenetum bulgaricae; 7 - Lino tenuifolii-Jurineetum brachycephalae.

Напівжирним шрифтом виділені діагностичні види, сірим кольором - високодіагностичні

Diagnostic species are highlighted in bold, and gray are highly diagnostic 
Таблиця 2. Фітоценотична характеристиа союзу Festucion valesiacae

Table 2. Phytocoenotic characteristics of the alliance Festucion valesiacae

\begin{tabular}{|c|c|c|c|c|c|c|c|c|c|c|c|c|c|c|c|}
\hline Номер опису & 1 & 2 & 3 & 4 & 5 & 6 & 7 & 8 & 9 & 10 & 11 & 12 & 13 & 14 & 15 \\
\hline Крутизна схилу, градуси & 5 & 3 & 3 & 5 & 2 & 2 & 5 & 2 & 2 & 2 & 3 & 5 & 3 & 2 & 3 \\
\hline Експозиція & $\mathrm{N}$ & $\mathrm{E}$ & NW & NE & NE & $\mathrm{W}$ & $\mathrm{N}$ & NE & $\mathrm{NE}$ & $\mathrm{NE}$ & $\mathrm{E}$ & $\mathrm{N}$ & NE & NW & $\mathrm{NE}$ \\
\hline Загальне проективне покриття , \% & 95 & 80 & 80 & 90 & 80 & 80 & 95 & 95 & 85 & 90 & 80 & 90 & 85 & 85 & 80 \\
\hline Кількість видів в описі & 24 & 27 & 27 & 24 & 29 & 26 & 26 & 24 & 30 & 29 & 27 & 27 & 23 & 27 & 26 \\
\hline \multicolumn{11}{|c|}{ D. sp. ass. Potentillo arenarie-Stipetum capillatae } & & & & & \\
\hline Stipa capillata & 2 & 2 & 2 & 2 & 4 & 4 & 2 & 2 & 4 & 2 & • & $\cdot$ & - & - & • \\
\hline Euphorbia sequierana & + & + & • & $\cdot$ & + & + & $\cdot$ & • & + & + & $\cdot$ & $\cdot$ & $\cdot$ & $\cdot$ & + \\
\hline Festuca rupicola & 3 & 2 & 3 & 2 & - & 4 & 4 & 2 & 1 & 1 & 3 & - & - & - & • \\
\hline Achillea pannonica & 1 & 1 & 1 & 1 & 1 & 1 & 1 & 1 & 1 & + & 1 & $\cdot$ & 1 & - & • \\
\hline Potentilla incana & 1 & 1 & 1 & 1 & 1 & $\cdot$ & • & 1 & - & - & • & $\cdot$ & - & - & 1 \\
\hline Agropyron pectinatum & 1 & • & - & - & • & 1 & $\cdot$ & 1 & • & + & $\cdot$ & $\cdot$ & - & - & + \\
\hline Phlomis pungens & + & + & - & + & • & $\cdot$ & + & 1 & - & - & • & $\cdot$ & - & - & • \\
\hline Koeleria cristata & - & 1 & - & 1 & - & $\cdot$ & $\cdot$ & + & - & 1 & $\cdot$ & $\cdot$ & - & - & - \\
\hline Astragalus ucrainicus & - & $\cdot$ & • & + & • & $\cdot$ & $\cdot$ & - & + & - & • & $\cdot$ & - & - & - \\
\hline \multicolumn{16}{|c|}{ D. sp. ass. Salvio nemorosae-Festucetum valesiacae var. Botriochloetum ischaemii } \\
\hline Medicago falcata & $\cdot$ & $\cdot$ & - & $\cdot$ & • & $\cdot$ & $\cdot$ & + & - & + & 1 & 1 & 1 & 1 & 1 \\
\hline Viola ambigua & + & $\cdot$ & $\cdot$ & + & • & + & $\cdot$ & $\cdot$ & - & + & $\cdot$ & 1 & + & + & + \\
\hline Senecio jacobaea & $\cdot$ & - & • & $\cdot$ & • & $\cdot$ & $\cdot$ & • & • & - & + & $\cdot$ & + & - & $\cdot$ \\
\hline Salvia nemorosa & - & • & 3 & 2 & • & 4 & 2 & - & - & - & 4 & 4 & 3 & 2 & 2 \\
\hline \multicolumn{16}{|l|}{ D. sp. all. Festucion valesiacae } \\
\hline Festuca valesiaca & 4 & 3 & 3 & 2 & 4 & $\cdot$ & $\cdot$ & 2 & - & • & 2 & 3 & 4 & 2 & 3 \\
\hline Salvia nemorosa & - & - & 3 & 2 & $\cdot$ & 4 & 2 & - & $\cdot$ & - & 4 & 4 & 3 & 2 & 2 \\
\hline Bothriochloa ischaemum & 4 & 2 & 3 & 2 & 4 & 1 & 2 & 2 & 2 & 1 & 2 & 2 & 4 & & 2 \\
\hline Convolvulus arvensis & - & + & 1 & + & $\cdot$ & + & $\cdot$ & + & + & + & + & + & + & $\cdot$ & $\cdot$ \\
\hline Astragalus austriacus & + & • & + & + & 1 & $\cdot$ & $\cdot$ & - & - & + & 1 & • & + & 1 & - \\
\hline Artemisia austriaca & • & $\cdot$ & • & $\cdot$ & $\cdot$ & + & $\cdot$ & + & • & • & $\cdot$ & $\cdot$ & • & • & • \\
\hline Adonis vernalis & 1 & $\cdot$ & $\cdot$ & + & $\cdot$ & • & $\cdot$ & • & + & 1 & $\cdot$ & $\cdot$ & $\cdot$ & + & $\cdot$ \\
\hline Erucastrum armoracioides & $\cdot$ & $\cdot$ & + & • & $\cdot$ & $\cdot$ & $\cdot$ & $\cdot$ & $\cdot$ & $\cdot$ & + & $\cdot$ & + & 1 & $\cdot$ \\
\hline Falcaria vulgaris & - & $\cdot$ & + & $\cdot$ & • & $\cdot$ & $\cdot$ & - & + & + & $\cdot$ & $\cdot$ & + & - & + \\
\hline Senecio vernalis & $\cdot$ & + & - & $\cdot$ & $\cdot$ & $\cdot$ & $\cdot$ & + & $\cdot$ & + & $\cdot$ & $\cdot$ & • & $\cdot$ & $\cdot$ \\
\hline Elytrigia intermedia & • & $\cdot$ & $\cdot$ & • & • & $\cdot$ & $\cdot$ & $\cdot$ & - & 2 & $\cdot$ & 1 & $\cdot$ & - & - \\
\hline Poa angustifolia & • & $\cdot$ & $\cdot$ & • & • & $\cdot$ & $\cdot$ & • & 2 & 1 & $\cdot$ & $\cdot$ & $\cdot$ & $\cdot$ & $\cdot$ \\
\hline Plantago stepposa & • & $\cdot$ & $\cdot$ & • & + & $\cdot$ & $\cdot$ & • & • & + & $\cdot$ & + & $\cdot$ & - & $\cdot$ \\
\hline Galium ruthenicum & - & $\cdot$ & - & - & - & $\cdot$ & • & - & $\cdot$ & 1 & + & $\cdot$ & - & - & $\cdot$ \\
\hline Hypericum elegans & - & + & + & $\cdot$ & - & $\cdot$ & $\cdot$ & • & + & + & $\cdot$ & $\cdot$ & - & + & $\cdot$ \\
\hline Bromopsis riparia & $\cdot$ & - & $\cdot$ & $\cdot$ & - & $\cdot$ & $\cdot$ & 1 & 1 & $\cdot$ & • & $\cdot$ & - & $\cdot$ & - \\
\hline Tanacetum millefolium & - & • & $\cdot$ & $\cdot$ & - & + & $\cdot$ & $\cdot$ & 1 & $\cdot$ & $\cdot$ & $\cdot$ & $\cdot$ & $\cdot$ & 1 \\
\hline Phlomis tuberosa & $\cdot$ & $\cdot$ & - & $\cdot$ & - & $\cdot$ & $\cdot$ & $\cdot$ & $\cdot$ & - & $\cdot$ & + & - & - & \\
\hline \multicolumn{16}{|l|}{ D. sp. cl. Festuco-Brometea } \\
\hline Stipa lessingiana & 2 & + & 1 & 1 & 2 & 1 & 2 & 2 & $\cdot$ & 1 & $\cdot$ & 1 & 1 & 1 & 1 \\
\hline Teucrium chamaedrys & • & + & • & $\cdot$ & 1 & 1 & 1 & $\cdot$ & 1 & • & $\cdot$ & 1 & • & 1 & \\
\hline
\end{tabular}




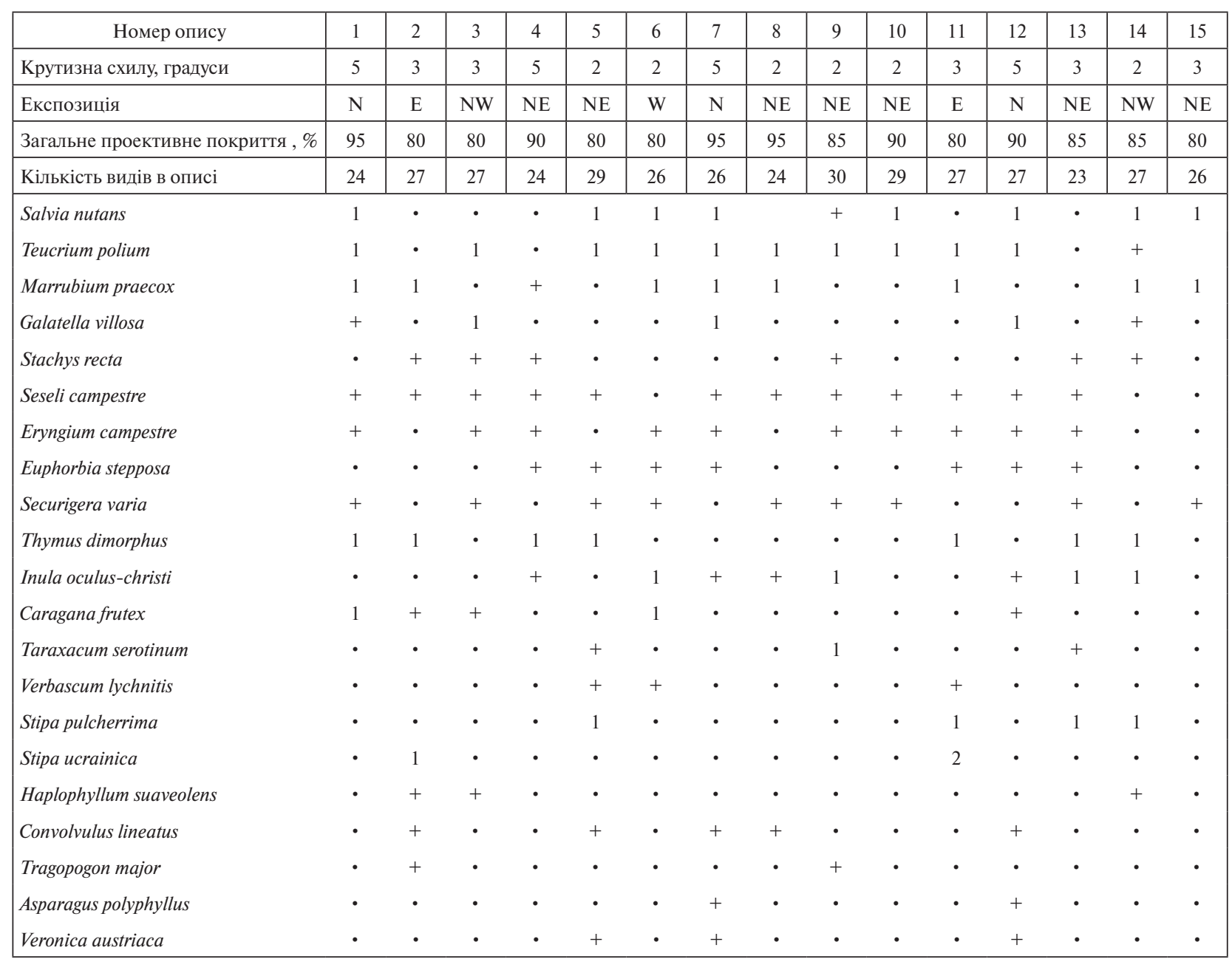

Траплялися лише в одному або двох описах (тут і далі в дужках наведені: номер опису та бал проективного покриття): Achillea submillefolium (15:+), Agrimonia eupatoria (12:+), Ajuga chia (5:+, 14:+), Alyssum calycinum (10:+, 15:+), Anagallis caerulea (2:+, 8:+), Asperula cynanchica (5:+, 15:+), Astragalus albidus (4:+, 15:+), A. corniculatus (9:+), A.dasyanthus (11:+, 14:+), A. onobrychis (3:+, 14:+), A. ucrainicus (4:+, 9:+), Bromopsis inermis (6:+), Caragana scythica (14:+), Carduus thoermeri $(5:+)$, Carex hirta $(11:+)$, Centaurea marschalliana $(1:+, 5:+)$, Cleistogenes bulgarica $(7:+, 15:+)$, Clematis integrifolia $(12:+)$, Clypeola jonthlaspi (2:+, 8:+), Consolida regalis (6:+), Crataegus fallacina (7:+, 12:+), Crepis tectorum (11:+), Eremogone bibersteinii (3:+, 13:+), Eremogone rigida (9:+), Erysimum cheiranthoides $(15:+)$, Galium ruthenicum $(10:+, 11:+)$, Grindelia squarrosa (12:+), Helichrysum arenarium (7:+), Hieracium pilosella $(15:+)$, Hyacinthella pallasiana $(9: 1)$, Hypericum maculatum (2:+), Hypericum perforatum (5:+), Jurinea arachnoidea (14:+), Koeleria brevis (15:+), Lactuca serriola (11:+), Lamium amplexicaule (8:+, 15:+), Lathyrus tuberosus (11:+), Linum austriacum (13:+), Linum hirsutum (14:+), Linum tenuifolium (7:+), Marrubium leonuroides (10:+), Melica transsilvanica (7:+), Nepeta parviflora $(7:+, 12:+)$, Nigella arvensis $(6:+)$, Nonea pulla $(5:+$, 11:+), Otites chersonensis $(15:+)$, Papaver rhoeas $(5:+)$, Poa compressa $(2:+)$, Potentilla astracanica $(15:+)$, Potentilla recta $(1:+$, 15:+), Poterium polyganum (15:+), Salvia aethiopis $(9:+, 15:+)$, Salvia austriaca $(3:+, 10:+)$, Sisymbrium polymorphum (4:+), Sonchus oleraceus (8:+), Stellaria holostea $(3:+, 11:+)$, Vinca herbacea $(9:+)$, Vincetoxicum hirundinaria (5:+), Xeranthemum annum (6:+).

Описи зроблено: 1, 2, 4 - 29.05.2017, Сланецьке відділення; 3, 11, 13 - 26.05.2018, Михайлівське відділення; 5, 9 15.05.2018, Єланецьке відділення; 6 - 30.06.2017, Михайлівське відділення; 7, 12 - 05.07.2017, Єланецьке відділення; 8, 10 - 28.05.2018, Михайлівське відділення. 
Таблиця 3. Фітоценотична характеристика союзу Stipion lessingianae

Table 3. Phytocoenotic characteristics of the alliance Stipion lessingianae

\begin{tabular}{|l|c|c|c|c|c|c|c|c|c|c|c|c|c|c|c|}
\hline \multicolumn{1}{|c|}{ Номер опису } & 1 & 2 & 3 & 4 & 5 & 6 & 7 & 8 & 9 & 10 & 11 & 12 & 13 & 14 & 15 \\
\hline Крутизна схилу, град & 10 & 5 & 8 & 8 & 10 & 5 & 5 & 10 & 10 & 5 & 5 & 5 & 3 & 3 & 3 \\
\hline Експозиція & $\mathrm{N}$ & $\mathrm{E}$ & $\mathrm{NE}$ & $\mathrm{E}$ & $\mathrm{SE}$ & $\mathrm{NW}$ & $\mathrm{NE}$ & $\mathrm{NE}$ & $\mathrm{NE}$ & $\mathrm{NW}$ & $\mathrm{E}$ & $\mathrm{NW}$ & $\mathrm{SE}$ & $\mathrm{SE}$ & $\mathrm{E}$ \\
\hline Кількість видів в описі & 28 & 27 & 30 & 23 & 30 & 35 & 27 & 33 & 25 & 23 & 35 & 25 & 26 & 25 & 28 \\
\hline Загальне проективне покриття (\%) & 90 & 85 & 90 & 85 & 85 & 90 & 92 & 90 & 95 & 95 & 95 & 80 & 90 & 90 & 90 \\
\hline
\end{tabular}

D. sp. ass. Vinco herbaceae-Caraganetum fruticis

Vinca herbacea

Caragana frutex

Chamaecytisus graniticus

Astragalus ucrainicus

Adonis vernalis

Clematis integrifolia

\begin{tabular}{|lllll|}
\hline 1 & 2 & 1 & 2 & 1 \\
4 & 3 & 2 & 4 & 2 \\
3 & 4 & 2 & 2 & 2 \\
+ & + & 1 & - & 1 \\
1 & 1 & 1 & 1 & + \\
+ & - & - & + & + \\
\hline
\end{tabular}

D. sp. ass. Stipo lessingianae-Salvietum nutantis

Crinitaria villosa

Inula oculus-christi

Tanacetum millefolium

Linum hirsutum

Veronica austriaca

D. sp. ass. Plantagini stepposae-Stipetum pulcherrimae

Astragalus onobrychis

Astragalus austriacus

Stipa pulcherrima

Stipa lessingiana

Salvia nutans

Ephedra distachya

D. sp. all. Stipion lessingianae

Stachys recta

Marrubium praecox

Jurinea arachnoidea

Plantago urvillei

Viola ambigua

Phlomis pungens

Clematis integrifolia

Nepeta parviflora

Helichrysum arenarium

Galium octonarium

D. sp. cl. Festuco-Brometea

Festuca valesiaca

Euphorbia stepposa

Achillea pannonica

Teucrium polium

Stipa ucrainica

Teucrium chamaedrys 


\begin{tabular}{|c|c|c|c|c|c|c|c|c|c|c|c|c|c|c|c|}
\hline Номер опису & 1 & 2 & 3 & 4 & 5 & 6 & 7 & 8 & 9 & 10 & 11 & 12 & 13 & 14 & 15 \\
\hline Крутизна схилу, град & 10 & 5 & 8 & 8 & 10 & 5 & 5 & 10 & 10 & 5 & 5 & 5 & 3 & 3 & 3 \\
\hline Експозиція & $\mathrm{N}$ & $\mathrm{E}$ & $\mathrm{NE}$ & $\mathrm{E}$ & $\mathrm{SE}$ & NW & $\mathrm{NE}$ & $\mathrm{NE}$ & $\mathrm{NE}$ & NW & $E$ & NW & SE & $\mathrm{SE}$ & $\mathrm{E}$ \\
\hline Кількість видів в описі & 28 & 27 & 30 & 23 & 30 & 35 & 27 & 33 & 25 & 23 & 35 & 25 & 26 & 25 & 28 \\
\hline Загальне проективне покриття (\%) & 90 & 85 & 90 & 85 & 85 & 90 & 92 & 90 & 95 & 95 & 95 & 80 & 90 & 90 & 90 \\
\hline Stipa capillata & $\cdot$ & + & - & $\cdot$ & $\cdot$ & - & 1 & $\cdot$ & 1 & 2 & $\cdot$ & 1 & $\cdot$ & 1 & \\
\hline Thalictrum minus & 1 & + & 1 & + & + & + & + & + & + & - & $\cdot$ & - & + & $\cdot$ & 1 \\
\hline Thymus dimorphus & $\cdot$ & 1 & 2 & 2 & 1 & 2 & $\cdot$ & 2 & + & - & $\cdot$ & 2 & 2 & $\cdot$ & 2 \\
\hline Convolvulus arvensis & . & • & - & + & • & - & + & • & • & . & + & . & + & + & \\
\hline Seseli campestre & $\cdot$ & $\cdot$ & + & $\cdot$ & + & - & $\cdot$ & + & - & - & + & + & $\cdot$ & + & \\
\hline Eryngium campestre & $\cdot$ & + & - & $\cdot$ & $\cdot$ & + & $\cdot$ & $\cdot$ & + & - & $\cdot$ & - & + & 1 & + \\
\hline Medicago falcata & 1 & $\cdot$ & 1 & $\cdot$ & 1 & - & $\cdot$ & $\cdot$ & - & + & + & 1 & + & - & - \\
\hline Securigera varia & $\cdot$ & $\cdot$ & - & $\cdot$ & + & + & $\cdot$ & $\cdot$ & + & + & + & - & $\cdot$ & + & \\
\hline Senecio erucifolius & $\cdot$ & $\cdot$ & - & $\cdot$ & $\cdot$ & + & $\cdot$ & + & $\cdot$ & - & + & - & $\cdot$ & $\cdot$ & \\
\hline Convolvulus lineatus & 2 & 1 & - & $\cdot$ & $\cdot$ & - & + & $\cdot$ & + & - & $\cdot$ & - & $\cdot$ & - & - \\
\hline Sisymbrium polymorphum & $\cdot$ & $\cdot$ & + & $\cdot$ & $\cdot$ & - & $\cdot$ & + & • & $\cdot$ & + & + & + & + & + \\
\hline Potentilla incana & + & 1 & 1 & $\cdot$ & $\cdot$ & $\cdot$ & $\cdot$ & $\cdot$ & • & • & $\cdot$ & - & $\cdot$ & $\cdot$ & $\cdot$ \\
\hline Falcaria vulgaris & $\cdot$ & + & - & $\cdot$ & - & + & $\cdot$ & $\cdot$ & - & - & + & - & $\cdot$ & + & - \\
\hline Salvia nemorosa & $\cdot$ & $\cdot$ & - & + & $\cdot$ & + & $\cdot$ & $\cdot$ & + & - & 1 & - & 2 & $\cdot$ & 1 \\
\hline Festuca rupicola & $\cdot$ & $\cdot$ & • & $\cdot$ & $\cdot$ & - & 1 & $\cdot$ & - & 2 & • & - & 1 & $\cdot$ & · \\
\hline Senecio jacobaea & + & + & - & $\cdot$ & $\cdot$ & - & $\cdot$ & $\cdot$ & - & - & + & - & + & $\cdot$ & • \\
\hline Hypericum elegans & 1 & + & - & $\cdot$ & + & - & $\cdot$ & $\cdot$ & - & - & $\cdot$ & - & $\cdot$ & $\cdot$ & • \\
\hline Bothriochloa ischaemum & $\cdot$ & $\cdot$ & 1 & 1 & + & $\cdot$ & $\cdot$ & + & - & • & $\cdot$ & - & $\cdot$ & $\cdot$ & · \\
\hline Viola kitaibeliana & $\cdot$ & $\cdot$ & - & $\cdot$ & $\cdot$ & - & $\cdot$ & + & - & - & $\cdot$ & - & + & + & $\cdot$ \\
\hline Lathyrus tuberosus & - & $\cdot$ & - & $\cdot$ & $\cdot$ & - & $\cdot$ & + & - & • & - & - & + & + & . \\
\hline Haplophyllum suaveolens & $\cdot$ & $\cdot$ & • & $\cdot$ & $\cdot$ & • & $\cdot$ & $\cdot$ & - & - & + & - & + & + & - \\
\hline Salvia aethiopis & $\cdot$ & $\cdot$ & - & $\cdot$ & $\cdot$ & + & $\cdot$ & $\cdot$ & - & - & + & - & $\cdot$ & $\cdot$ & - \\
\hline Verbascum lychnitis & $\cdot$ & $\cdot$ & + & $\cdot$ & $\cdot$ & - & $\cdot$ & $\cdot$ & - & + & $\cdot$ & + & $\cdot$ & $\cdot$ & • \\
\hline Iris pumila & $\cdot$ & + & - & $\cdot$ & $\cdot$ & - & $\cdot$ & + & $\cdot$ & - & $\cdot$ & + & $\cdot$ & $\cdot$ & - \\
\hline Euphorbia sequierana & $\cdot$ & $\cdot$ & - & $\cdot$ & $\cdot$ & - & $\cdot$ & $\cdot$ & - & - & + & - & $\cdot$ & + & + \\
\hline Onosma macrochaeta & . & - & + & . & . & - & • & • & . & . & . & . & . & + & + \\
\hline
\end{tabular}

Траплялися лише в одному або двох описах Achillea setacea (6:+), Agropyron pectinatum (6:+), Ajuga chia (11:+, 12:+), Allium sphaerocephalon (10:+), Alyssum desertorum (5:+), Anchusa officinalis (13:+), Artemisia austriaca (11:+), Asparagus officinalis (12:+), Asparagus polyphyllus (1:+, 7:+), Asperula Montana (10:+, 11:+), Astragalus albicaulis (5:+), Astragalus albidus $(11:+, 15:+)$, Astragalus corniculatus (5:+), Astragalus dasyanthus (8:+, 15:+), Astragalus odessanus (7:+), Bellevalia sarmatica $(6:+, 11:+)$, Bromopsis inermis $(8:+, 15:+)$, Bromopsis riparia $(11:+, 12:+)$, Campanula sibirica $(11:+)$, Carduus acanthoides $(11:+)$, Carduus thoermeri (7:+), Carex praecox (5:1),Crambe tataria $(6:+)$, Crataegus fallacina $(6:+)$, Ephedra distachya $(8:+$, 11:2), Eremogone bibersteinii (11:+, 15:+), Galium odoratum (3:+), Galium ruthenicum (7:+, 10:+), Herniaria glabra (2:+), Hypericum maculatum (12:+), Hypericum perforatum (3:+), Iris pontica (1:+), Koeleria cristata (5:+), Lactuca serriola (14:+), Linaria biebersteinii (6:+), L. vulgaris(15:+), Linum austriacum $(15:+)$, L. tenuifolium (7:+), Lithospermum officinale (3:+), Lysimachia nummularia (1:+), Ornithogalum fischeranum (4:+), Orobanche purpurea $(13:+)$, Oxytropis pilosa $(3:+, 5:+)$, Phlomis tuberosa (6:+, 9:+), Plantago lanceolata (10:+), Potentilla astracanica $(1:+)$, Poterium polyganum (5:+), Reseda lutea (4:+), Salvia austriaca $(6:+, 13:+)$, Senecio vernalis(9:+), Sideritis montana $(9:+)$, Stellaria holostea $(13:+, 14:+)$, Taraxacum serotinum (9:+; 14:+), Tragopogon major (15:+), Verbascum phoeniceum $(11:+, 14:+)$, Veronica barrelieri $(8:+, 15:+)$

Описи зроблено: 1 - 12.05.2018, Єланецьке відділення; 2 - 15.05.2018, Сланецьке відділення; 3, 4, 5 - 13.05.2018, Єланецьке відділення; 6 - 27.05.2018; 7 - 05.07.2017, Єланецьке відділення; 8 - 26.05.2018; 9 - 05.07.2017, Єланецьке відділення; 10 - 28.06.2017, Михайлівське відділення; 11, 12, 15 - 27.05.2018, Михайлівське відділення; 13, 14 26.05.2018, Сланецьке відділення. 
Таблиця 4. Фітоценотична характеристика союзу Potentillo arenarie-Linion czerniaevii Table 4. Phytocoenotic characteristics of the alliance Potentillo arenarie-Linion czerniaevii

\begin{tabular}{|c|c|c|c|c|c|c|c|c|c|c|c|c|c|c|c|c|c|c|c|c|}
\hline Номер опису & 1 & 2 & 3 & 4 & 5 & 6 & 7 & 8 & 9 & 10 & 11 & 12 & 13 & 14 & 15 & 16 & 17 & 18 & 19 & 20 \\
\hline Крутизна схилу, град & 25 & 30 & 25 & 15 & 10 & 10 & 15 & 7 & 20 & 15 & 15 & 5 & 10 & 30 & 20 & 15 & 20 & 10 & 15 & 10 \\
\hline Експозиція & NE & $\mathrm{W}$ & W & SE & NE & NW & $\mathrm{N}$ & $\mathrm{N}$ & $\mathrm{E}$ & NE & $\mathrm{N}$ & SE & NE & $\mathrm{N}$ & NW & NE & $\mathrm{NE}$ & SE & $\mathrm{E}$ & SE \\
\hline Загальне проективне покриття (\%) & 70 & 45 & 65 & 70 & 80 & 65 & 85 & 85 & 65 & 60 & 50 & 75 & 80 & 60 & 60 & 70 & 65 & 80 & 75 & 60 \\
\hline Кількість видів в описі & 22 & 17 & 24 & 17 & 23 & 25 & 26 & 31 & 21 & 33 & 31 & 43 & 41 & 26 & 29 & 29 & 32 & 30 & 29 & 29 \\
\hline \multicolumn{21}{|c|}{ D. sp. ass. Lino tenuifolii - Jurineetum brachycephalae } \\
\hline Jurinea brachycephala & 1 & 1 & 2 & 3 & 4 & 2 & 3 & • & 1 & • & • & • & • & - & - & $\cdot$ & - & • & - & • \\
\hline Genista scythica & 1 & $\cdot$ & • & 4 & • & - & 3 & 1 & • & 3 & 1 & • & • & $` 1$ & • & • & 1 & • & - & - \\
\hline Linum tenuifolium & + & + & 1 & - & • & - & 1 & 1 & 1 & 1 & + & + & - & • & + & • & $\cdot$ & • & 1 & • \\
\hline Stipa pulcherrima & 2 & $\cdot$ & - & 2 & • & - & 1 & 2 & 1 & • & • & • & $\cdot$ & • & - & • & $\cdot$ & 1 & - & • \\
\hline \multicolumn{21}{|l|}{ D. sp. ass. Cleistogenetum bulgaricae } \\
\hline Cleistogenes bulgarica & • & $\cdot$ & - & - & - & - & • & $\cdot$ & $\cdot$ & • & 1 & 2 & 2 & 1 & 2 & 2 & 1 & 3 & 2 & 3 \\
\hline Paronychia cephalotes & - & $\cdot$ & - & • & $\cdot$ & - & $\cdot$ & $\cdot$ & $\cdot$ & • & + & + & 1 & 1 & 1 & 1 & $\cdot$ & • & $\cdot$ & • \\
\hline Inula oculus-christi & - & $\cdot$ & • & - & - & • & $\cdot$ & $\cdot$ & $\cdot$ & - & • & 1 & 1 & $\cdot$ & $\cdot$ & • & 1 & 1 & $\cdot$ & $\cdot$ \\
\hline Achillea pannonica & $\cdot$ & $\cdot$ & - & - & $\cdot$ & • & $\cdot$ & • & - & 1 & - & 1 & - & - & 1 & 1 & 1 & 1 & $\cdot$ & 1 \\
\hline Ajuga chia & - & $\cdot$ & • & - & • & - & - & $\cdot$ & $\cdot$ & + & $\cdot$ & + & $\cdot$ & + & $\cdot$ & + & $\cdot$ & $\cdot$ & + & $\cdot$ \\
\hline Senecio erucifolius & - & $\cdot$ & • & $\cdot$ & - & • & $\cdot$ & $\cdot$ & • & $\cdot$ & • & + & + & • & $\cdot$ & • & $\cdot$ & - & $\cdot$ & + \\
\hline Medicago falcata & - & $\cdot$ & • & • & • & - & $\cdot$ & • & • & • & • & $\cdot$ & 1 & 1 & $\cdot$ & 1 & 1 & 1 & $\cdot$ & + \\
\hline Astragalus austriacus & $\cdot$ & $\cdot$ & - & - & • & - & + & - & • & + & 1 & + & 1 & 1 & $\cdot$ & 1 & $\cdot$ & $\cdot$ & + & + \\
\hline \multicolumn{21}{|c|}{ D. sp. all. Potentillo arenarie-Linion czerniaevii } \\
\hline Centaurea marschalliana & 1 & $\cdot$ & 1 & 1 & 1 & 1 & 1 & • & 1 & 1 & 1 & 2 & 2 & 2 & 2 & 2 & 3 & 2 & $\cdot$ & 2 \\
\hline Poterium polyganum & + & + & + & + & + & + & $\cdot$ & • & - & - & - & + & - & 2 & 1 & • & + & 1 & 1 & + \\
\hline Astragalus albidus & 4 & 4 & • & 2 & 4 & • & • & 3 & 2 & • & 1 & + & • & 3 & • & $\cdot$ & 1 & 1 & 1 & 1 \\
\hline Potentilla incana & $\cdot$ & $\cdot$ & 4 & • & 4 & - & 4 & • & + & 4 & 4 & $\cdot$ & • & 3 & 3 & 2 & 2 & • & 2 & 2 \\
\hline Viola ambigua & + & • & + & + & + & + & + & - & - & - & • & + & - & $\cdot$ & 1 & 1 & $\cdot$ & 1 & + & + \\
\hline Linaria genistifolia & + & • & $\cdot$ & $\cdot$ & $\cdot$ & - & $\cdot$ & + & $\cdot$ & $\cdot$ & $\cdot$ & $\cdot$ & - & - & $\cdot$ & + & $\cdot$ & $\cdot$ & + & $\cdot$ \\
\hline Convolvulus lineatus & 1 & $\cdot$ & 1 & - & $\cdot$ & - & • & - & $\cdot$ & 1 & • & 1 & - & • & $\cdot$ & $\cdot$ & + & $\cdot$ & $\cdot$ & $\cdot$ \\
\hline Onosma macrochaeta & $\cdot$ & $\cdot$ & • & $\cdot$ & + & • & $\cdot$ & + & • & • & • & $\cdot$ & $\cdot$ & + & • & $\cdot$ & $\cdot$ & • & + & • \\
\hline Alyssum desertorum & $\cdot$ & + & - & - & + & - & $\cdot$ & - & + & $\cdot$ & $\cdot$ & + & - & - & $\cdot$ & + & $\cdot$ & $\cdot$ & + & $\cdot$ \\
\hline Asperula cynanchica & • & $\cdot$ & + & - & - & • & • & • & + & $\cdot$ & $\cdot$ & + & - & + & $\cdot$ & $\cdot$ & - & 1 & $\cdot$ & $\cdot$ \\
\hline Potentilla pilosa & $\cdot$ & • & - & $\cdot$ & $\cdot$ & - & $\cdot$ & - & $\cdot$ & $\cdot$ & $\cdot$ & + & $\cdot$ & - & $\cdot$ & + & $\cdot$ & $\cdot$ & + & $\cdot$ \\
\hline Astragalus onobrychis & $\cdot$ & $\cdot$ & - & - & - & • & • & - & $\cdot$ & 1 & $\cdot$ & 1 & • & - & $\cdot$ & 2 & $\cdot$ & $\cdot$ & 1 & • \\
\hline Potentilla astracanica & $\cdot$ & $\cdot$ & - & - & $\cdot$ & $\cdot$ & + & + & $\cdot$ & $\cdot$ & + & $\cdot$ & 1 & $\cdot$ & $\cdot$ & $\cdot$ & $\cdot$ & $\cdot$ & $\cdot$ & $\cdot$ \\
\hline \multicolumn{21}{|l|}{ D. sp. cl. Festuco-Brometea } \\
\hline Festuca valesiaca & 1 & $\cdot$ & • & • & 2 & 2 & 2 & 2 & 2 & $\cdot$ & $\cdot$ & 2 & 3 & $\cdot$ & 4 & 4 & 3 & 3 & $\cdot$ & 3 \\
\hline Teucrium polium & 1 & 1 & • & 1 & 1 & 1 & 1 & 1 & • & 1 & 1 & 1 & • & 2 & 3 & • & 4 & • & 1 & • \\
\hline Euphorbia stepposa & + & + & + & • & + & $\cdot$ & • & - & + & + & + & + & + & $\cdot$ & + & • & + & + & • & + \\
\hline
\end{tabular}




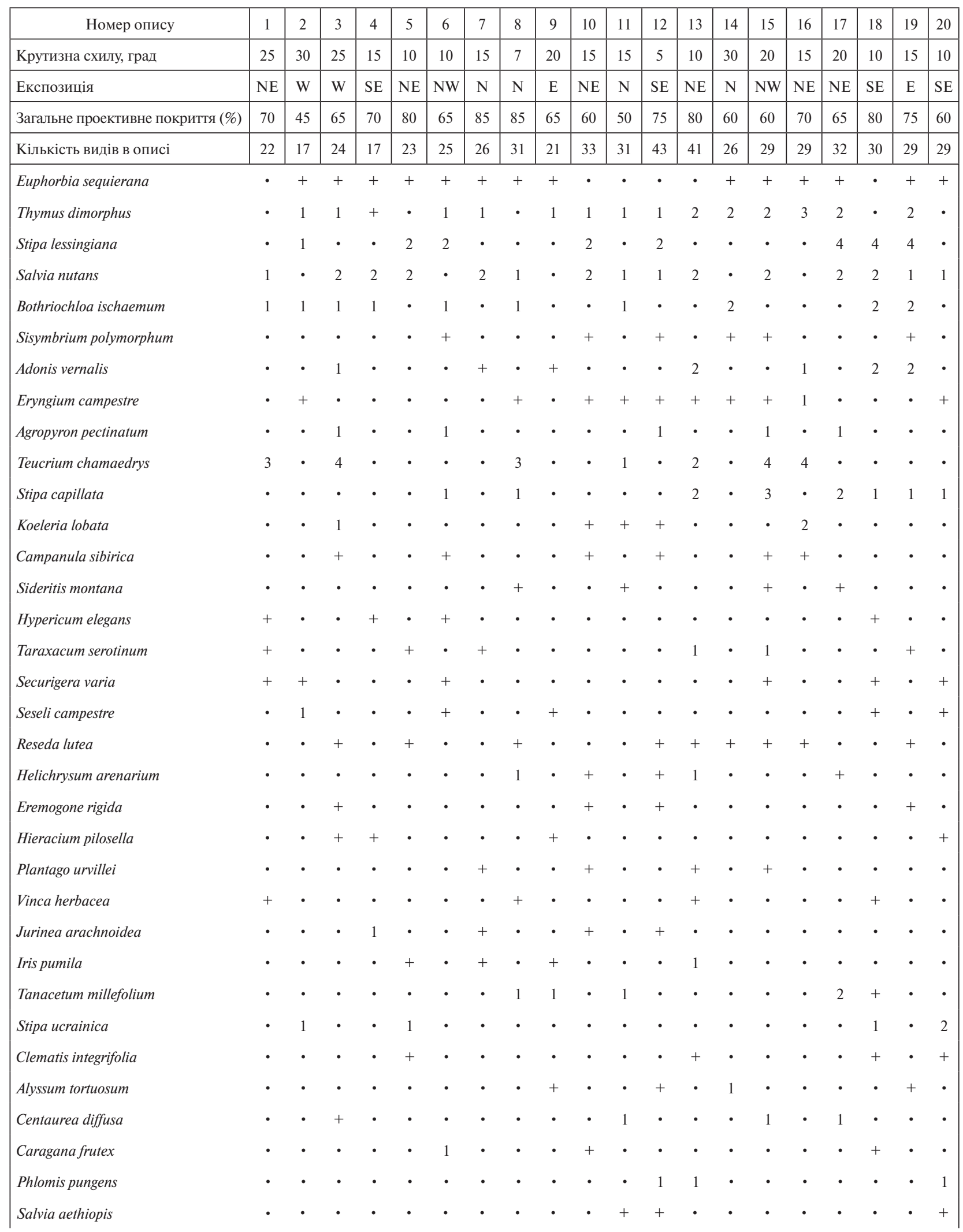




\begin{tabular}{|c|c|c|c|c|c|c|c|c|c|c|c|c|c|c|c|c|c|c|c|c|}
\hline Номер опису & 1 & 2 & 3 & 4 & 5 & 6 & 7 & 8 & 9 & 10 & 11 & 12 & 13 & 14 & 15 & 16 & 17 & 18 & 19 & 20 \\
\hline Експозиція & $\mathrm{NE}$ & $\mathrm{W}$ & W & SE & NE & NW & $\mathrm{N}$ & $\mathrm{N}$ & $\mathrm{E}$ & $\mathrm{NE}$ & $\mathrm{N}$ & SE & NE & $\mathrm{N}$ & NW & NE & NE & SE & E & SE \\
\hline Загальне проективне покриття (\%) & 70 & 45 & 65 & 70 & 80 & 65 & 85 & 85 & 65 & 60 & 50 & 75 & 80 & 60 & 60 & 70 & 65 & 80 & 75 & 60 \\
\hline Кількість видів в описі & 22 & 17 & 24 & 17 & 23 & 25 & 26 & 31 & 21 & 33 & 31 & 43 & 41 & 26 & 29 & 29 & 32 & 30 & 29 & 29 \\
\hline Potentilla recta & + & $\cdot$ & $\cdot$ & $\cdot$ & • & + & $\cdot$ & $\cdot$ & $\cdot$ & • & - & • & • & + & • & - & • & • & • & - \\
\hline Linum austriacum & - & $\cdot$ & $\cdot$ & • & + & • & $\cdot$ & $\cdot$ & $\cdot$ & • & • & • & 1 & 1 & • & 1 & - & • & • & $\cdot$ \\
\hline Artemisia austriaca & • & • & $\cdot$ & • & • & • & $\cdot$ & + & • & • & + & + & 1 & • & • & 1 & 1 & • & • & • \\
\hline Marrubium rraecox & • & • & $\cdot$ & • & • & • & $\cdot$ & + & • & • & • & • & 2 & • & • & • & • & • & - & 2 \\
\hline Galatella villosa & • & • & $\cdot$ & • & • & • & 1 & $\cdot$ & • & + & $\cdot$ & • & • & • & • & • & • & 1 & - & • \\
\hline Veronica austriaca & $\cdot$ & • & + & $\cdot$ & • & • & $\cdot$ & + & $\cdot$ & $\cdot$ & • & • & 1 & • & $\cdot$ & • & $\cdot$ & • & $\cdot$ & $\cdot$ \\
\hline Thalictrum minus & - & • & $\cdot$ & - & $\cdot$ & • & + & $\cdot$ & $\cdot$ & - & - & $\cdot$ & 1 & • & - & - & - & • & $\cdot$ & + \\
\hline Melica transsilvanica & • & $\cdot$ & $\cdot$ & • & • & 1 & $\cdot$ & 1 & $\cdot$ & • & $\cdot$ & - & 1 & • & • & • & - & • & • & • \\
\hline Koeleria cristata & • & $\cdot$ & $\cdot$ & • & • & • & $\cdot$ & $\cdot$ & $\cdot$ & • & $\cdot$ & • & 2 & • & 1 & • & 1 & • & • & • \\
\hline Convolvulus arvensis & - & $\cdot$ & $\cdot$ & • & • & $\cdot$ & $\cdot$ & • & $\cdot$ & • & $\cdot$ & • & + & • & • & + & • & • & • & + \\
\hline Vincetoxicum hirundinaria & $\cdot$ & • & $\cdot$ & $\cdot$ & + & • & $\cdot$ & $\cdot$ & $\cdot$ & - & $\cdot$ & - & $\cdot$ & $\cdot$ & $\cdot$ & • & $\cdot$ & + & $\cdot$ & + \\
\hline Haplophyllum suaveolens & - & • & • & • & • & • & • & + & • & • & • & • & + & • & • & • & • & • & + & • \\
\hline
\end{tabular}

Траплялися лише в одному або двох описах: Allium flavescens (8:+), A. scorodoprassum (17:+), A. sphaerocephalon (13:+), Asparagus polyphyllus (10:+), Astragalus corniculatus (5:+), A. pubiflorus (16:+), A. ucrainicus (9:+,16:+), Bromopsis inermis $(8:+)$, B. riparia $(10:+, 12:+)$, Bromus squarrosus $(11:+)$, Bunias orientalis $(16:+)$, Caragana mollis $(10:+)$, Centaurea orientalis $(8:+)$, Chamaecytisus graniticus (1:+, 7:+), Chondrilla juncea (14:+), Crambe tataria (12:+), Crataegus fallacina (15:+), Dianthuus pseudoarmeria (13:+), Echium vulgare $(13:+)$, Ephedra distachya $(10:+)$, Falcaria vulgaris $(16:+, 18:+)$, Galium octonarium (7:+, 20:+), Galium ruthenicum (8:+, 17:+), Goniolimon besseranum $(1:+, 13:+)$, Hedysarum grandiflorum $(2:+)$, Hieracium umbellatum $(6:+)$, Hyacinthella pallasiana $(5:+)$, Hypericum perforatum $(3:+)$, Iris pontica $(7:+, 13:+)$, Isatis tinctoria (12:+, 19:+), Koeleria brevis (6:+), Lactuca serriola (18:+, 20:+), Lamium amplexicaule (12:+), Linaria biebersteinii (11:+), L. macroura (2:+), Linum czerniaevii (10:+), L. hirsutum (15:+), M. lupulina (16:+), Minuartia leiosperma (14:+), Nepeta parviflora (13:+), Odontites vulgaris (9:+), Onobrychis tanaitica (10:+), Picris echioides (8:+), Pimpinella titanophila (14:+), Poa angustifolia (4:+), Poa bulbosa (11:+, 13:+), P. compressa (7:+), Polygala sibirica (18:+), Poterium sanqusorba (7:+), Pulsatilla pratensis (4:+), Rosa corymbifera $(6:+, 14:+)$, Senecio vernalis $(6:+)$, Silene armeria $(13:+)$, Thesium arvense $(6:+)$, Thymelaea passerina $(11:+)$, Xeranthemum annum $(11:+, 17:+)$.

Описи зроблено: 1, 7 - 12.05.2018, Сланецьке відділення; 2, 3 - 11.06.2018, Сланецьке відділення; 4, 5, 9 -15.05.2018, Єланецьке відділення; 6 -29.05.2017, Єланецьке відділення; 8 - 06.07.2017, Єланецьке відділення; 10 - 27.05.2018, Михайлівське відділення; 11 - 04.07.2017, Єланецьке відділення; 12 - 27.05.2018; 13 - 03.07.2017, Єланецьке відділення; 14 - 26.05.2017, Михайлівське відділення; 15 - 05.07.2017, Єланецьке відділення; 16, 19 - 25.05.2018, Михайлівське відділення; 17 - 04.07.2017, Єланецьке відділення; 18, 20 - 14.05.2018, Сланецьке відділення. 
Klokov, Linum tenuifolium L., Poterium polyganum Waldst. \& Kit.

Константні види: Adonis vernalis, Campanula sibirica L., Euphorbia stepposa, Festuca valesiaca, Helichrysum arenarium, Hypericum elegans, Onosma macrochaeta Klokov \& Dobrocz., Potentilla incana, Potentilla astracanica, Reseda lutea, Salvia nutans, Stipa capillata, S. lessingiana S. pulcherrima, Taraxacum serotinum Waldst. \& Kit., Teucrium chamaedrys, T. polium, Thymus dimorphus, Viola ambigua.

Домінантні види: Festuca valesiaca, Jurinea brachycephala, Potentilla incana, Teucrium chamaedrys, Astragalus albidus, Genista scythica.

Угруповання приурочені до нижньої або середньої частини схилів різної експозиції на кам'янистих виступах вапняку. Грунтовий покрив незначний або часто відсутній, флористичне багатство (в середньому 24 види в описі) залежить від ступеня сформованості грунту. Значну роль у формуванні угруповань відіграють види родів Astragalus L., Linum L., а також Genista scythica, Jurinea brachycephala.

\section{Асоціація Cleistogenetum bulgaricae}

Діагностичні види: Achillea pannonica, Ajuga chia Schreb., Astragalus albidus, A. austriacus, Centaurea marschalliana, Cleistogenes bulgarica (Bornm.) Keng, Inula oculus-christi, Medicago falcata, Paronychia cephalotes (M.Bieb.) Besser, Senecio erucifolius L.

Константні види: Agropyron pectinatum, Alyssum desertorum Stapf, Alyssum tortuosum Waldst. \& Kit., Artemisia austriaca Jacq., Asperula cynanchica L., Bothriochloa ischaemum, Campanula sibirica, Centaurea diffusa Lam., Cleistogenes bulgarica, Festuca valesiaca, Helichrysum arenarium, Koeleria cristata, Koeleria lobata (M.Bieb.) Roem. \& Schult., Paronychia cephalotes, Phlomis pungens, Potentilla incana, P. pilosa, Poterium polyganum, Reseda lutea, Sideritis montana, Stipa capillata, Tanacetum millefolium, Taraxacum serotinum, Teucrium chamaedrys, Teucrium polium, Thymus dimorphus, Viola ambigua.

Домінантні види: Festuca valesiaca, Teucrium polium, Thymus dimorphus, Teucrium chamaedrys, Stipa lessingiana.

Асоціація включає угруповання, що формуюються на ділянках із порушеним грунтовим покривом зі значним вмістом вапнякового дрібнозему (30-40\%), зазвичай із домішками глини. Поширені на вапнякових схилах, прилеглих до агроценозів, зазнають впливу змиву з полів.
Однак не є флористично збідненими (середня кількість в описі видів 31).

Слід зазначити, що навіть в умовах заповідного режиму близьке розташування агроценозів до ділянок зі степовою рослинністю та відсутність перехідних зон негативно впливають на стан угруповань. Обробка полів гербіцидами, змив і деградація грунту призводять до порушень гідрота сольового режимів, і як наслідок, до зменшення родючості грунту. Окрім того, на більшій частині Михайлівського відділення відбувається випасання худоби. Також існує небезпека поширення 3 лісосмуг деревних адвентивних видів (Cotinus coggygria Scop., Elaeagnus angustifolia L., Gleditsia triacanthos L., Ulmus pumila L.), які мають здатність до порушення структури біоценозів.

\section{Висновки}

Аналіз степової рослинності класу FestucoBrometea на території природного заповідника "Еланецький степ" показав ii ценотичну та біотопічну різноманітність. Вона представлена лучними степами днищ балок; асоціаціями, що $\epsilon$ стадією відновлення після впливу людської діяльності; цілинними степами та ценозами вапнякових відслонень. Майже всі угруповання $€$ флористично цінними, оскільки мають у своєму складі ендемічні та рідкісні види, що охороняються на державному та міжнародному рівнях. Особливо багатими та непорушеними $\mathrm{\epsilon}$ асоціації Stipo lessingianae-Salvietum nutantis, Plantagini stepposaeStipetum pulcherrimae, Lino tenuifolii-Jurineetum brachycephalae. Найкраще збереження даних ценозів пояснюється їхнім розташуванням на схилах балок, оскільки переважно усі плакорні ділянки були розорані. Асоціації Potentillo arenariaeStipetum capillatae, Salvio nemorosae-Festucetum valesiacae var. Botriochloetum ischaemii формуються в менш сприятливих умовах, під впливом випасу.

Встановлено, що на досліджуваній території на степову рослинність впливать негативні фактори, такі як аграрна діяльність, перевипас, поширення авентивних видів. 


\section{СПИСОК ПОСИЛАНЬ}

Braun-Blanquet J. 1964. Pflanzensoziologie. Grundzuge der Vegetationskunde, vol. 3. Aufl. Wien-New York: SpringerVerlag, 865 pp.

Vynokurov D.S. 2014a. Ukrainian Botanical Journal, 71(2): 148-160. [Винокуров Д.С. 2014а. Синтаксономія ксеротермної рослинності долини р. Інгул (клас Festuco-Brometea). Ч. 1. Петрофітно-степова рослинність. Український ботанічний журнал, 71(2): 148160]. https://doi.org/10.15407/ukrbotj71.02.148

Vynokurov D.S. 2014b. Ukrainian Botanical Journal, 71(5): 537-548. [Винокуров Д.С. 2014b. Синтаксономія ксеротермної рослинності долини р. Інгул (клас Festuco-Brometea). Ч. 2. Лучно-степова, чагарниково-степова, справжньостепова рослинність. Український ботанічний журнал, 71(5): 537-548]. https://doi. org/10.15407/ukrbotj71.05.537

Vynokurov D.S. 2016. Vegetation of the Ingul River valley: syntaxonomy, dynamics, conservation: Cand. Sci. Diss. Abstract. Kyiv, M.G. Kholodny Institute of Botany NAS of Ukrane, 21 pp. [Винокуров Д.С. 2016. Рослинність долини р. Інгул: синтаксономія, динаміка, охорона: автореф. дис. ... канд. біол. наук: 03.00.05 "Ботаніка". Київ, Інститут ботаніки ім. М.Г. Холодного НАН України, 21 с.].

Grunty Mykolaivskoi oblasti. 1969. Ed. S.P. Vinnytskyi. Odesa: Mayak, 59 рр. [Грунти Миколаївської області. 1969. Ред. С.П. Вінницький. Одеса: Маяк, 59 с.].

Derkach O.M. 2005. In: Teoriya i praktyka zapovidnoi spravy v Ukraini. Zbirnyk naukovykh prats. Kyiv, pp. 161-168. [Деркач О.М. 2005. Ключові ботанічні території Миколаївщини: сучасний стан та проблеми збереження. В зб.: Теорія і практика заповідної справи в Україні. Зб. наук. праць. Київ, с. 161-168].

Derkach O.M. 2011. In: Materialy druhykh naukovykh chytan pam'yati Serhiya Tarashchuka (Mykolaiv, 6-11 April, 2011). Mykolaiv: Vydavnytstvo Chornomorskoho Universytetu, pp. 52-55. [Деркач О.М. 2011. До питання розширення території природного заповідника "Еланецький степ". У зб.: Матеріали других наукових читань пам'яті Сергія Тарашука (Миколаїв, 6-11 квітня 2011 р.). Миколаїв: Вид-во Чорноморського університету, с. 52-55].

Didukh Ya.P., Shelyag-Sosonko Yu.R. 2003. Ukrainian Botanical Journal, 60(1): 6-17. [Дідух Я.П., ШелягСосонко Ю.Р. 2003. Геоботанічне районування України та суміжних територій. Український ботанічний журнал, 60(1): 6-17].

Didukh Ya.P., Korotchenko I.A. 2003. Visnyk Lvivskoho natsionalnoho universytetu. Series Biology, 34: 82-91. [Дідух Я.П., Коротченко I.А. 2003. Ксеротермна рослинність північно-західного Поділля. Вісник Львівського національного університету. Серія біологічна, 34: 82-91].

Didukh Ya.P., Vashenyak Yu.A. 2012. Ukrainian Botanical Journal, 69(6): 789-817. [Дідух Я.П., Вашеняк Ю.А. 2012. Степова рослинність Центрального Поділля. Український ботанічний журнал, 69(6): 789-817].
Didukh Ya.P., Chusova O.O. 2014. Ukrainian Botanical Journal, 71(3): 275-285. [Дідух Я.П., Чусова О.О. 2014. Рідкісні ксерофітно-степові угруповання та біотопи долини р. Красна (Луганська обл.). Український ботанічний жсурнал, 71(3): 275-285]. https://doi. org/10.15407/ukrbotj71.03.275

Fiziko-geograficheskoe rayonirovanie Ukrainskoy SSR . 1968. Eds V.P. Popova, A.M. Marinicha, A.I. Lanko. Kiev: Kiev University, 683 pp. [Физико-географическое районирование Украинской ССР. 1968. Под ред. В.П. Попова, А.М. Маринича, А.И. Ланько. Киев: Изд-во Киевского университета, 683 с.].

Hennekens S.M., Schaminée J.H.J. 2001. TURBOVEG, a comprehensive date base management system for vegetation data. Journal of Vegetation Science, 12: 589591. https://doi.org/10.2307/3237010

Hill M.O. 1979. TWINSPAN - a FORTRAN program for arranging multivariate data in an ordered two-way table by classification of the individuals and the attributes. New York: Ithaca, 48 pp.

Kolomiychuk V.P., Moysiyenko I.I., Derkach O.M., Boyko T.O. 2012. In: Phytodiversity of nature reserves and national nature parks of Ukraine. Part 1. Nature reserves. Eds V.A. Onyshchenko, T.L. Andrienko. Kyiv: Phytosociocentre, pp. 124-138. [Коломійчук В.П., Мойсієнко I.I., Деркач О.М., Бойко Т.О. 2012. ПЗ Еланецький степ. В кн.: Фіторізноманіття заповідників $і$ національних природних парків України. Ч. 1. Біосферні заповідники. Природні заповідники. Ред. В.А.Онищенко, Т.Л.Андрієнко. Київ: Фітосоіоцентр, с. 124-138].

Kolomiychuk V., Vynokurov D. 2016. Syntaxonomy of the Festuco-Brometea class vegetation of the Azov Sea coastal zone. Hacquetia, 15(2): 79-104. https://doi. org/10.1515/hacq-2016-0018

Korotchenko I.A., Didukh Ya.P. 1997. Ukrainian Phytosociological Collection. Series A, 1(6): 20-39. [Koротченко І.А., Дідух Я.П. 1997. Степова рослинність південної частини Лівобережного Лісостепу України. II. Клас Festuco-Brometea. Український фітоценологічний збірник. Серія A, 1(6): 20-39].

Korotchenko I.A., Mala Yu.I., Fitsaylo T.V. 2009a. Naukovyi visnyk Chernivetskoho natsionalnoho universytetu. Series biolohyya, biolohichni systemy, 1(1): 73-84. [Коротченко І.А., Мала Ю.І., Фіцайло Т.В. 2009а. Синтаксономія степової рослинності крайньої півночі Правобережного Степу України. Науковий вісник Чернівецького національного університету. Серія біологія, біологічні системи, 1(1): 73-84].

Korotchenko I.A., Mala Yu.I., Fitsaylo T.V. 2009b. Naukovi zapysky NaUKMA. Biolohiya ta ekolohiya, 93: 54-69. [Коротченко I.А., Мала Ю.І., Фіцайло Т.В. 2009 b. Синтаксономія степової рослинності крайнього півдня Правобережного Лісостепу України. Наукові записки НаУКМА. Біологія та екологія, 93: 54-69].

Kostyliov O.V. 1987. Ukrainian Botanical Journal, 44(2): 77-81. [Костильов О.В. 1987. Рослинність запроектованого заповідника "Еланецький". Український ботанічний журнал, 44(2): 77-81].

Krasova O.O., Smetana M.H. 1999. Ukrainian Phytosociological Collection. Series A, 1-2(12-13): 
21-30. [Красова О.О., Сметана М.Г. 1999. Степова рослинність балки Кобильної. Український фітоценологічний збірник. Серія А, 1-2 (12-13): 21-30].

Kutyna I., Drewniak E., Mlynowiak E. 2011. Xerothermic grasslands within the area of the eastern margin of the Oder River valley in the vicinity of the town of Gorzyca. Annales Universitatis Marie Curie-Sklodowska. Sectio C, 64(1): 55-84.

Mirkin B.M., Rozenberg G.S., Naumova L.G. 1989. Slovar ponyatiy i terminov sovremennoy fitotsenologii. Moscow: Nauka, 223 pp. [Миркин Б.М., Розенберг Г.С., Наумова Л.Г. 1989. Словарь понятий и терминов современной фитоценологии. Москва: Наука, 223 с.].

Mosyakin S.L., Fedoronchuk M.M. 1999. Vascular plants of Ukraine. A nomenclatural checklist. Kiev, 345 pp. + xxiii.

Moysiyenko I.I., Solomakha V.A., Drabynyuk H.V., Solomakha T.D. 2005. Chornomorski Botanical Journal, 1(2): 83-91. [Мойсієнко I.I., Соломаха В.А., Драбинюк Г.В., Соломаха Т.Д. 2005. Еколого-ценотичні особливості Scutellaria verna Besser в умовах природного заповідника "Еланецький степ" (Миколаївська обл., Україна). Чорноморський ботанічний журнал, 1(2): 83-91].

Mucina L., Bültmann H., Dierßen K., Theurillat J.P., Raus T., Čarni A., Šumberová K. 2016. Vegetation of Europe: hierarchical floristic classification system of vascular plant, bryophyte, lichen, and algal communities. Applied Vegetation Science, 19(1): 1-783.
Roleček J., Tichý L., Zelený D., Chytrý M. 2009. Modified TWINSPAN classification in which the hierarchy respects cluster heterogeneity. Journal of Vegetation Science, 20: 596-602. https://doi. org/10.1111/j.1654-1103.2009.01062.x

Tichý L. 2002. JUICE, software for vegetation classification. Journal of Vegetation Science, 13: 451-453.

Tkachenko V.S. 2009. Chornomorski Botanical Journal, 5(3): 319-332. [Ткаченко В.С. 2009. Структурні зміни в рослинному покриві "Еланецького степу" за перше десятиліття існування. Чорноморський ботанічний журнал, 5(3): 319-332].

Tkachenko V.S., Sirotenko P.O. 1999. Ukrainian Botanical Journal, 56(6): 623-629. [Ткаченко В.С., Сиротенко П.О. 1999. Вихідний стан рослинності "Еланецького степу" в системі фітоценотичного моніторингу. Український ботанічний журнал, 56(6): 623-629].

Tkachenko V.S., Ostrivna Yu.I. 2006. Ukrainian Botanical Journal, 63(5): 681-693. [Ткаченко В.С., Острівна Ю.І. 2006. Синфітоіндикаційна характеристика вихідного стану природного заповідника "Еланецький степ". Український ботанічний журнал, 63(5): 681-693].

Рекомендує Д.В. Дубина 


\title{
New data on distribution of the endangered species Viola jooi (Violaceae) in Ukraine
}

\author{
Jan Roleček ${ }^{1,2}$, Pavel Dřevojan ${ }^{1}$ \\ ${ }^{1}$ Department of Botany and Zoology, Faculty of Science, Masaryk University \\ 2 Kotlářská, Brno 611 37, Czech Republic \\ ${ }^{2}$ Department of Vegetation Ecology, Institute of Botany, Czech Academy of Sciences \\ 25/27 Lidická, Brno 657 20, Czech Republic \\ honza.rolecek@centrum.cz \\ pavel.drevojan@seznam.cz
}

Roleček J., Dřevojan P. 2019. New data on distribution of the endangered species Viola jooi (Violaceae) in Ukraine. Ukrainian Botanical Journal, 76(6): 526-532.

Abstract. Here we report the third extant site of Viola jooi in Ukraine. The species was found on an open calcareous scree in the valley of the Tlumach stream near Ostrynia village (Tlumach District, Ivano-Frankivsk Region). Vegetation of the scree may be classified to a broadly circumscribed alliance Stipion calamagrostis or to its east-central European counterpart Teucrion montani (class Thlaspietea rotundifolii). Moreover, our survey of Ukrainian and Polish herbaria revealed several specimens collected during the 1930s at two sites not yet mentioned in the literature, with one of the sites situated near our newly found site. We see a need for a thorough field survey of the historical, extant and other suitable sites of the species in the area of its present distribution in the Ukraine. Despite the new finds, Viola jooi remains one of the rarest relicts of the ancient heliophilous flora of the Volyn-Podolian Upland, pointing to its peri-Alpidic biogeographical affinities. Conservation priorities should be in line with this status.

Keywords: endangered species, plant distribution, Podnistrovia, Pokuttia, relict, scree vegetation

Submitted 08 October 2019. Published 29 December 2019

Ролечек Я. ${ }^{1,2}$, Држевоян П. ${ }^{1}$ 2019. Нові дані щодо поширення зникаючого виду Viola jooi (Violaceae) в Україні. Український ботанічний журнал, 76(6): 526-532.

'Університет Масарика вул. Котляржська 37, Брно 611 37, Чеська Республіка

${ }^{2}$ Інститут ботаніки, Академія Наук Чеської Республіки вул. Лідіцька 25/27, Брно 657 20, Чеська Республіка

Реферат. У статті повідомляється про третю знахідку Viola jooi в Україні. Вид був знайдений на відкритих вапнякових осипах у долині р. Тлумач поблизу с. Остриня (Тлумацький район, Івано-Франківська область). Рослинність цих осипів може бути віднесена до союзу Stipion calamagrostis у широкому розумінні або до його східноцентральноєвропейського відповідника Teucrion montani (клас Thlaspietea rotundifolii). Крім того, у матеріалах гербаріїв з України та Польщі було знайдено декілька зразків, зібраних протягом 1930-х років у двох місцезнаходженнях, які раніше не наводилися в літературі, а одне з цих місцезнаходжень розташоване поблизу нещодавно знайденого нами локалітету. Отже, потрібно проводити ретельні польові дослідження як історичних, так і теперішніх, а також інших можливих локалітетів виду в межах регіону його сучасного поширення в Україні. Незважаючи на нові знахідки, Viola jooi залишається одним із найрідкісніших реліктів давньої геліофільної флори Волино-Подільської височини, що вказує на її пери-альпідні (периферійні до зон Альпійського орогенезу) біогеографічні зв'язки. Пріоритети охорони цього виду мають відповідати його статусу.

Ключові слова: зникаючий вид, поширення рослин, Подністров'я, Покуття, релікт, рослинність осипів

(C) 2019 J. Roleček, P. Dřevojan. Published by the M.G. Kholodny Institute of Botany, NAS of Ukraine. This is an open access article under the terms of the Creative Commons Attribution License (http://creativecommons.org/licenses/by/4.0/), which permits use, distribution, and reproduction in any medium, provided the original work is properly cited 


\section{Introduction}

Violajooi Janka is a rare species with a narrow distribution range, encompassing mainly the Eastern and Southern Carpathians in Romania. Outside Romania, a single site was reported from Serbia (Homoljske Planine Mts, Southern Carpathians) and two sites from Ukraine (Niketić et al., 2015). The Ukrainian sites are situated in the Pokuttia historical region near Chortovets and Harasymiv villages (Shelyag-Sosonko et al., 1980; Didukh, 2009), about $130 \mathrm{~km}$ north of the nearest sites in north-eastern Romania (cf. Niketić et al., 2015). The species is classified as vulnerable in the Red Data Book of Ukraine (Didukh, 2009) and as rare in the Romanian red list (Oltean et al., 1994). Its estimated threat status in Serbia is critically endangered species (Niketić et al., 2015). Habitats of the species in Ukraine include mainly gypsum outcrops with steppe grassland vegetation dominated by Carex humilis, Helictotrichon desertorum and Sesleria heuflerana, where it is accompanied by other rare ecological specialists such as Draba podolica (Schivereckia podolica) and Thalictrum petaloideum (incl. T. podolicum) (Koczwara, 1931; Didukh, 2009; Roleček et al., 2019).

Discovery of Viola jooi within the present-day territory of Ukraine has been ascribed to the Polish botanist Tadeusz Wilczyński (Koczwara, 1931; Zabłocki, 1947). Koczwara himself reported $V$.jooi from three phytosociological relevés recorded in June 1927 near Chortovets village on gypsum outcrops by the road to Obertyn (Koczwara, 1931; Fig. 1). The place likely corresponds to the Boldy site (also called Zholob) where the species is still present (Didukh, 2009). There are multiple herbarium specimens from this site in Krakow (KRA, KRAM), Lviv (LWS) and Kyiv (KW) herbaria, the oldest one coming from 1928 (see Overview of the studied herbarium specimens). Another site reported in the Red Data Book of Ukraine is located 10 kilometres to the north-west, on slopes of a gypsum sinkhole between Zhabokruky, Harasymiv and Zhyvachiv villages (Ya.P. Didukh pers. comm.; Fig. 1). A single specimen from this site is present in $\mathrm{KW}$.

The aim of this paper is to report a new site of Violajooi in Ukraine, which was found during a field trip in April 2019, and to provide additional new data on species' distribution retrieved from the literature and herbaria. These findings change the picture of distribution of $V$.jooi in the country.

\section{Study area}

The study area (Fig. 1) is situated in the northern part of the historical region of Pokuttia, which is a part of a physiographic region of the PokutianBessarabian Upland (IEU, 2019). It is predominantly built of calcareous sediments of the Neogene and Cretaceous age, mainly gypsum and marlstones (Vashchenko et al., 2007). The landscape is mildly undulating and largely used as farmlands. Incised valleys of the Dniester and its tributaries provide suitable habitats for the remnants of natural and seminatural non-forest vegetation, such as steppe grasslands, vegetation of rocky outcrops and screes (Koczwara, 1931; Didukh, Korotchenko, 2000; Didukh, Vasheniak, 2018; Roleček et al., 2019). Karst features, particularly sinkholes, developed in the Neogene gypsum deposits, provide additional habitats for these vegetation types (Didukh, Pavliuk, 2008).

\section{Methods}

Taxonomic concepts and nomenclature of vascular plant taxa follow Euro +Med PlantBase (2006-onward), with the exception of Ligularia glauca, for which we use the concept of Flora Europaea (Tutin et al., 1976). Syntaxonomic nomenclature follows Mucina et al. (2016); full references are provided for syntaxa not included in this source. Vegetation composition was recorded using $2 \times 2 \mathrm{~m}$ plot and standard phytosociological methodology, with the extended Braun-Blanquet scale used for species cover-abundance estimation (Dengler et al., 2008). Acronyms of herbaria follow Index Herbariorum (Thiers, 2008-onward).

\section{Results}

A new site of Viola jooi was found during a survey of steppe vegetation on steep slopes of the valley of Tlumach stream near Ostrynia village (Tlumach District, Ivano-Frankivsk Region, Western Ukraine; Fig. 1). Herbarium vouchers are deposited in the Herbarium of the Masaryk University (BRNU) in Brno. Several dozens of individuals were found on the south-west facing open marlstone scree (Fig. 2) and in adjacent dry grasslands. Species composition of the scree vegetation was recorded using the following phytosociological relevé.

Ukraine, Ivano-Frankivsk Region, Tlumach District, Ostrynia village, steep slope above right bank of the Tlumach stream, latitude $48^{\circ} 55^{\prime} 40.9^{\prime \prime} \mathrm{N}$, longitude $24^{\circ} 59^{\prime} 12.3^{\prime \prime} \mathrm{E}$ (WGS-84), altitude $250 \mathrm{~m}$ a.s.l., plot size 


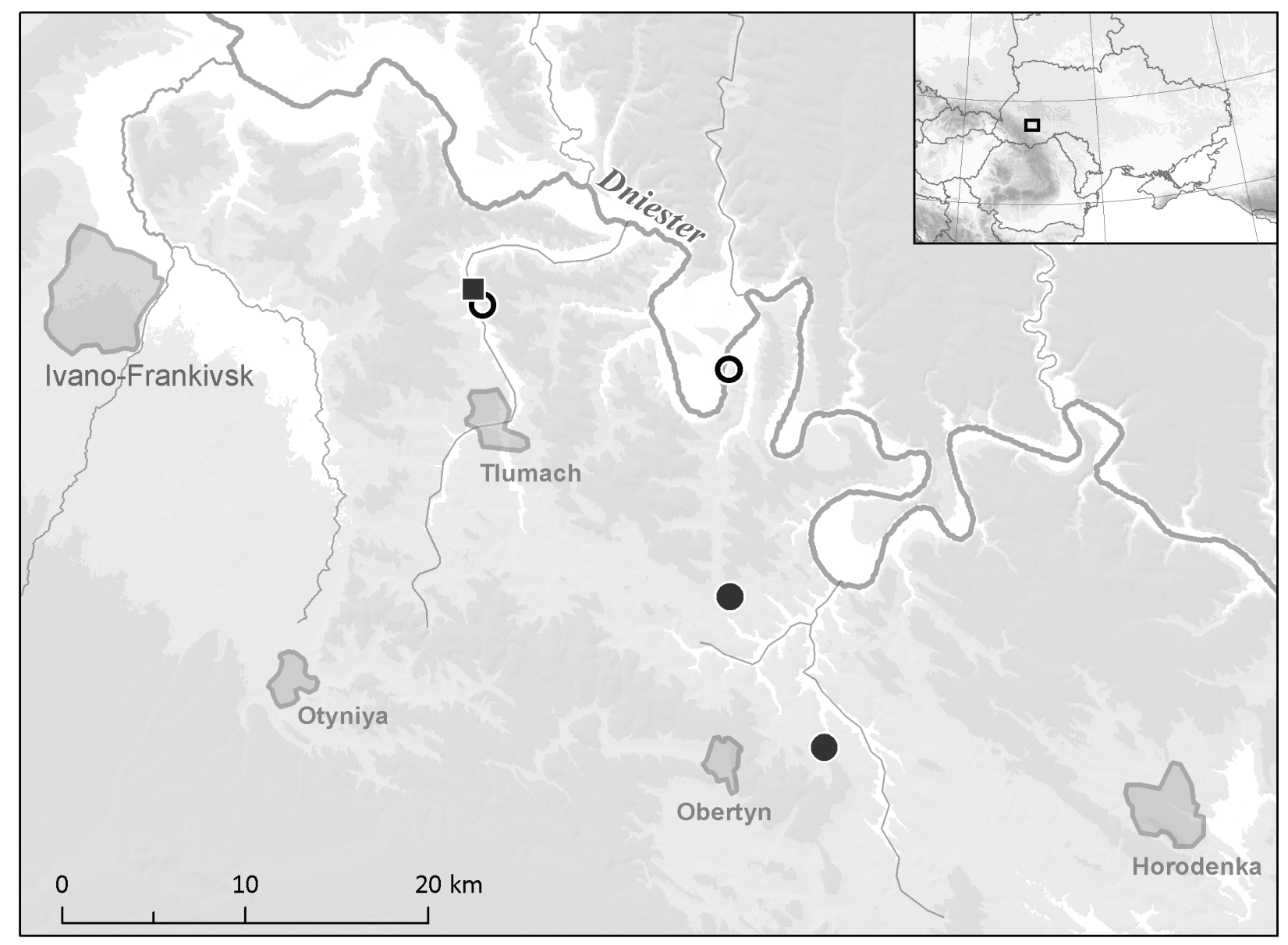

Fig. 1. Distribution of Viola jooi in Ukraine. Full square - newly found extant site; full circles - extant sites reported by Didukh (2009); empty circles - sites of the newly discovered herbarium specimens collected in the 1930s

$4 \mathrm{~m}^{2}$, slope inclination $40^{\circ}$, slope aspect $200^{\circ}$, cover of herb layer $5 \%$, cover of moss layer $<1 \%$. Authors: J. Roleček \& P. Dřevojan. Date: 17 April 2019.

Herb layer: Teucrium montanum 1, Allium lusitanicum + , Asperula cynanchica +, Bupleurum falcatum +, Euphorbia cyparissias + , Ranunculus breyninus + , Salvia verticillata + , Securigera varia + , Teucrium chamaedrys + , Viola jooi + , Arrhenatherum elatius $\mathrm{r}$, Daucus carota $\mathrm{r}$, Echium vulgare r, Sanguisorba minor $\mathrm{r}$.

During our subsequent survey of botanical literature and herbaria we identified two additional sites not yet reported in the relevant Ukrainian and Polish literature (Zabłocki, 1947; Shelyag-Sosonko et al.; 1980; Didukh, 2009):

i) Suchodól [= Sukhodil] village, Dniester valley near Brzezina grange (J. Mądalski, 1934, KRAM);

ii) slopes above Pałahicze $[=$ Palahychi $]$ village (J. Mądalski, 1936, KRAM).
Detailed information on the herbarium specimens are provided in Appendix 1. Summary data of the known past and present localities of Viola jooi in Ukraine is provided in Fig. 1.

\section{Discussion}

\section{New finds}

While the latest overview of the distribution of Viola jooi in Ukraine (Didukh, 2009) mentions two historical sites (both reported as still existing), we discovered three additional sites. The extant site near Ostrynia, which was found during a field trip in 2019, represents the northernmost point of species' known distribution (cf. Niketić et al., 2015).

Perhaps even bigger surprise was a discovery of two historical sites of Viola jooi in the herbarium of the W. Szafer Institute of Botany, Polish Academy of 


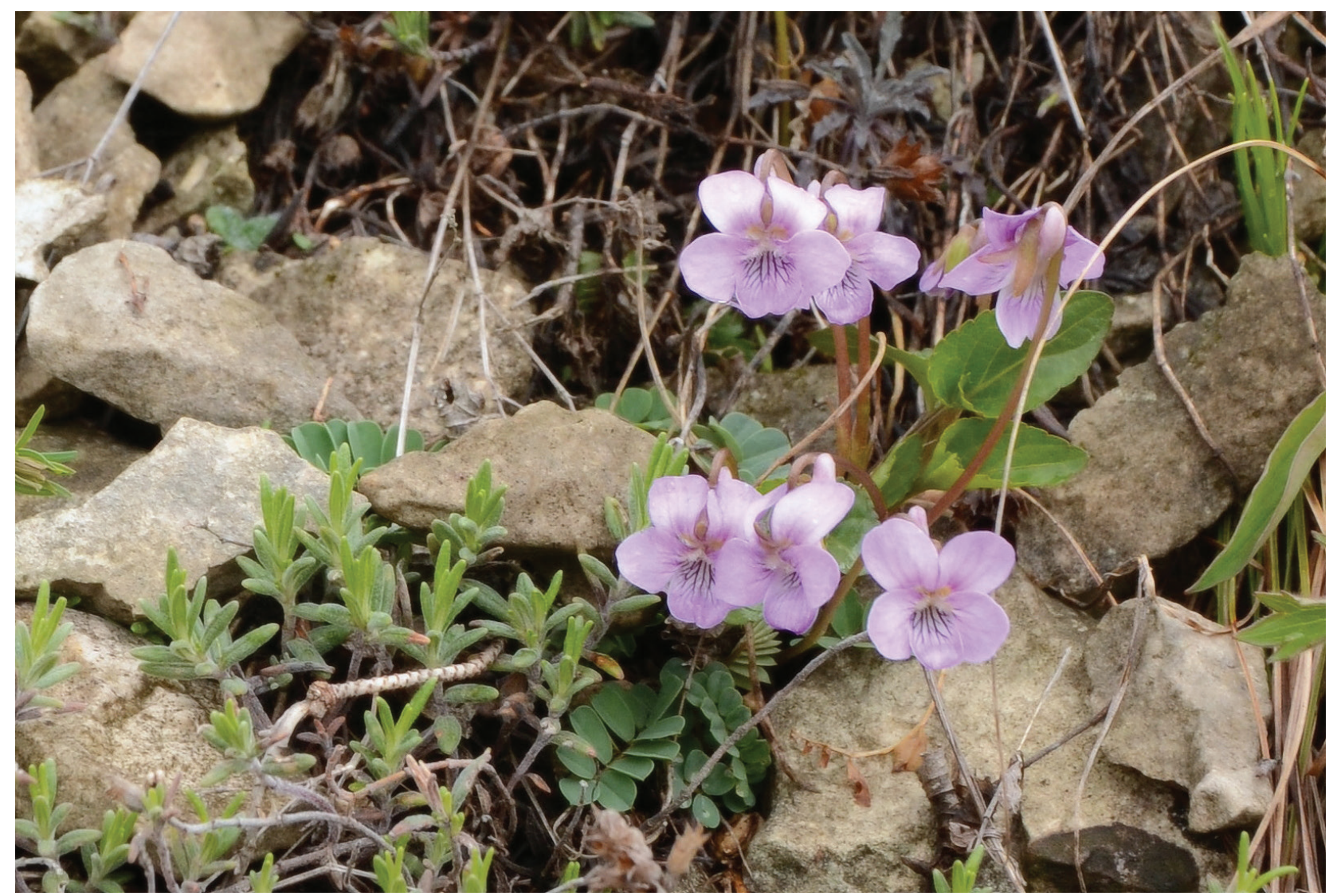

Fig. 2. Viola jooi at its newly found site near Ostrynia village. Teucrium montanum, a dominant species of the habitat, and Securigera varia are also visible

Sciences, Krakow (KRAM), kindly checked by Agnieszka Nikel. Respective specimens were collected by the Polish botanist Józef Mądalski in the 1930s, when the whole area of interest was a part of Poland. Mądalski worked at Jan Kazimierz University in Lviv. After the expulsion of Poles from the region by the end of World War II he moved to Wrocław, but later he handed over his personal herbarium to Krakow (see https://pl.wikipedia.org/wiki/Józef_Mądalski).

The site near Palahychi is located just about $1 \mathrm{~km}$ south-west of the extant site found by us and thus may be considered as a single larger site. However, site conditions of the two places may differ, as the area provides outcrops of not only Cretaceous marlstones, but also of Neogene gypsum. The other site near Sukhodil is the first known place of occurrence of Viola jooi in the Dniester valley, which has been recognized as an important refugium for non-forest species (Didukh, Vasheniak, 2018). Additional habitats suitable for $V$. jooi still occur in the surroundings of both historical sites and we assume that a focused field survey might Український ботанічний журнал, 2019, 76(6) bring new interesting findings. The search in other relevant herbaria in Ukraine and Poland (KRA, KW, LW, LWS) brought no new information on distribution of the species. It should also be noted that $V$. jooi was repeatedly reported from the Ukrainian Carpathians (Klokov, 1955; Tzvelev, 1996; Novikoff, Hurdu, 2015) listed it among doubtful taxa for this region. However, the respective record is surely erroneous, because it was based on an incorrect geographical interpretation of the Pokuttia region by Klokov (1955), which was probably followed by Tzvelev (1996).

We hope that the new find reported here will stimulate interest in the species and that nature conservation priorities will meet its status and needs.

\section{Biogeography}

Despite the new finds, Viola jooi remains one of the rarest relicts of the ancient heliophilous flora of the Volyn-Podolian Upland. This flora includes various biogeographical and ecological elements, among which the continental steppe element and Central European 
(in a wide sense) montane element belong to most characteristic ones (Szafer, 1923; Gajewski, 1937; Zaveryukha, 1985; Didukh, Vasheniak, 2018). Viola jooi clearly belongs to the latter, showing dealpine ecological features and peri-Alpidic (in this case, peri-Carpathian) distribution. In this respect, the co-occurring Teucrium montanum and Ranunculus breyninus show certain similarities.

Although some authors (e.g. Szafer, 1923) suggested the Tertiary age for these relicts, we assume that extensive climatic fluctuations connected with multiple Pleistocene glacial-interglacial cycles (Ehlers, Gibbard, 2011) led to profound changes of species' distribution ranges. Therefore, the current distribution patterns of Viola jooi and other heliophilous relicts were probably determined rather by the extent of their ranges during the last Ice Age (Late Pleistocene) or early Holocene and by the rate of their retreat during the Holocene forest spread. Admittedly, in some cases (e.g. the species with extremely disjunct ranges such as Ligularia glauca and Thalictrum petaloideum) earlier events might have played more important roles.

\section{Vegetation}

Vegetation of the scree with Viola jooi in the Tlumach valley may be classified to a broadly circumscribed alliance Stipion calamagrostis (class Thlaspietea rotundifolii), which according to Mucina et al. (2016) includes the alliance Teucrion montani. The latter alliance is an alternative option for the classification of vegetation of low-altitude calcareous screes in east-central Europe (Valachovič et al., 1997). None of these alliances has been reported from Ukraine yet (Solomakha, 2008, Dubyna et al., 2019).

Previously, the species was reported from Ukraine only from dry grasslands on gypsum bedrock (Koczwara, 1931; Didukh, 2009). These have been classified to the association Ranunculo zapalowiczii-Helictotrichonetum desertori described by Kukovitsia et al. (1994). The association has been assigned to different higher syntaxa by different authors (Kukovitsia et al., 1994; Didukh, Korotchenko, 2000; Didukh, Vasheniak, 2018). Based on its species composition, physiognomy and ecology, we prefer its original assignment to the order of rocky steppes Stipo pulcherrimae-Festucetalia pallentis and the alliance Galio campanulati-Poion versicoloris or to its more broadly conceived analogue Bromo pannoniciFestucion csikhegyensis (see Mucina et al., 2016).

In Romania Viola jooi occupies mainly colline to alpine rock grasslands, outcrops and screes on calcareous bedrock, often dominated by Festuca pallens, Helictotrichon decorum, Sesleria heufleriana, S. rigida, Teucrium montanum or Thymus comosus (Csürös, Pop, 1965; Doniță et al., 2005; Šmarda, 2005). The new site by Ostrynia therefore fits well the ecological amplitude of the species.

\section{Overview of the studied herbarium specimens}

Tlumach Region: Ostrynia: SW-facing open marlstone scree and adjacent dry grasslands on the steep slope above the right bank of the Tlumach stream $1.2 \mathrm{~km}$ ENE from the church, 250 a.s.1., $48^{\circ} 55^{\prime} 40.9^{\prime \prime} \mathrm{N}$ \& 24 ${ }^{\circ} 59^{\prime} 12.3^{\prime \prime}$ E (P. Dřevojan \& J. Roleček, 17.04.2019, BRNU). - Pałahicze k. Tłumacza, na halawie na pd. stoku wzgórza na pd. od koty 331 (J. Mądalski, 16.04.1936, KRAM). - Suchodół, folwark Brzezina, na ścianie pr. brzegu Dniestru w jasnych zaroślach wśród lasu (J. Mądalski, 20.07.1934, KRAM). Suchodół koło Tłumacza, na lesistej ścianie prawego brzegu jaru Dniestru w miejscach jasnych, stepowych koło dawnego folw. Brzezina (J. Mądalski, 07.08.1936, KRAM). - Ivano-Frankovskaya obl., Tlumachskiy r-n. s. Gerasimov, severnyye krutyye sklony, form. Seslerieta heuflerianae [Ивано-Франковская обл., Тлумачский p-н, с. Герасимов, северные крутые склоны, форм. Seslerieta heuflerianae] (Ya.P. Didukh, 18.05.1979, KW).

Horodenka Region: Czortowiec - step (J. Dobrzańska, 29.05.1928, KRA). - Podole: Czortowiec koło Winogradu. Skałki stepowe (Anonymous [Wycieczka Inst. Bot. U. J.] 29.05.1928, KRAM). Pokucie step.: Czortowiec, step z Avena Besseri na stromem wzgórzu gipsowem (B. Pawłowski, 29.05.1928, KRAM). - Pokucie step.: Czortowiec. Step z Avena Besseri na stromem zboczu gipsowem (B. Pawłowski, 29.05.1928, KRAM). - Pokucie stepowe. Czortowiec (pow. Horodeński). Step z Avena Besseri na gipsowem, stromem zboczu (B. Pawłowski, 29.05.1928, KRA). - Pokucie; Czortowiec (A. Kozłowska, 30.05.1928, KRAM). - Czortowiec koło Obertyna, na stromych halawach na pd. zach. od wsi (J. Mądalski, 25.04.1934, KRAM, KW). - Ivano-Frankovskaya obl. Gorodenkovskiy r-n. s. Chortovets. Boldy. Kamenistyye obnazheniya i stepnyye sklony [Ивано-Франковская обл. Городенковский р-н. с. Чертовец. Болды. Каменистые обнажения и степные склоны] (Yu.R. Shelyag-Sosonko \& Ya.P. Didukh, 31.07.1977, KW). Ivano-Frankovskaya obl, Gorodenkovskiy r-n. s. Nazarenkovo [= Chortovets], ur. Galdy [= Boldy]. Severnyye krutyye sklony, formatsiya Helictotrichoneta besserii [Ивано-Франковская обл, Городенковский 
p-н. с. Назаренково [= Чортовец], ур. Галды [= Болды]. Северные крутые склоны, формация Helictotrichoneta besserii] (Ya.P. Didukh, 17.05.1979, KW). - Ivano-Frankivs'ka obl., Horodenkivs'kyy r-n., okol. s. Chortovets', ur. Baudy [= Boldy], vapnyakovi skeli [Івано-Франківська обл., Городенківський p-н., окол. с. Чортовець, ур. Бауди [= Болди], вапнякові скелі] (M.M. Fedoronchuk \& Ya.P. Didukh, 30.04.2007, KW).

\section{Acknowledgements}

We are indebted to Lubov Borsukiewicz, Illia I. Chorney, Yakiv P. Didukh, Agnieszka Nikel and Marcin Nobis for searching local herbaria and providing information on the species. Our thanks also go to Volodymyr Buchko who kindly provided logistic support during our field research, Ondřej Hájek for drawing the map, and Anna Kuzemko for useful comments.

\section{REFERENCES}

Csürös Ş., Pop I. 1965. Considerații generale asupra florei şi vegetației masivelor calcaroase din munții apuseni. Contributii Botanice, (1965): 113-131.

Dengler J., Chytrý M., Ewald J. 2008. Phytosociology. In: Encyclopedia of ecology, vol. 4. General ecology. Eds S.E. Jørgensen, B.D. Fath. Oxford: Elsevier, pp. 2767-2779.

Didukh Ya.P. 2009. Viola jooi. In: Chervona knyha Ukrainy. Roslynnyi svit (Red Data Book of Ukraine. Plant kingdom). Ed. Ya.P. Didukh. Kyiv: Globalconsulting, p. 620. [Дідух Я.П. 2009. Viola jooi. В кн.: Червона книга України. Рослинний світ. Ред. Я.П. Дідух. Київ: Глобалконсалтинг, с. 620].

Didukh Ya.P., Korotchenko I.A. 2000. Ukrainian Phytosociological Collection. Series A, Phytosociology, 16(1): 3-15. [Дідух Я.П., Коротченко І.А. 2000. Класифікація степової рослинності Покуття. Украйнський фітоценологічний збірник. Серія А. Фітосоціологія, 16(1): 3-15].

Didukh Ya.P., Pavliuk V.S. 2008. Ukrainian Botanical Journal, 65(4): 495-503. [Дідух Я.П., Павлюк В.С. 2008. Ландшафтно-екологічні особливості розподілу рослинних уруповань у карстових воронках Прутсько-Дністровського лісостепу. Український ботанічний журнал, 65(4): 495-503].

Didukh Ya.P., Vasheniak Yu.A. 2018. Vegetation of limestone outcrops in Western and Central Podillia (Ukraine). Tuexenia, 38: 419-444. https://doi. org/10.14471/2018.38.023

Doniță N., Popescu A., Paucă-Comănescu M., Mihăilescu S., Biriş I.A. 2005. Habitatele din România. Bucureşti: Editura Tehnică Silvică, 496 pp.

Dubyna D.V., Dzyuba T.P., Yemelyanova S.M., Bagrikova N.O., Borysova O.V., Borsukevych L.M., VynokurovD.S., GaponS.V., Gapon Yu.V., DavydovD.A., Dvoretskyy T.V., Didukh Ya.P., Zhmud O.I., Kozyr M.S., Konishchuk V.V., Kuzemko A.A., Pashkevych N.A., Ryff L.E., Solomakha V.A., Felbaba-Klushyna L.M.,
Fitsaylo T.V., Chorna H.A., Chorney I.I., ShelyagSosonko Yu.R., Yakushenko D.M. 2019. Prodromus roslynnosti Ukrainy (Prodrome of the vegetation of Ukraine). Eds D.V. Dubyna, T.P. Dzyuba. Kyiv: Naukova Dumka, 782 pp. [Дубина Д.В., Дзюба Т.П., Ємельянова С.М., Багрікова Н.О., Борисова О.В., Борсукевич Л.М., Винокуров Д.С., Гапон С.В., Гапон Ю.В., Давидов Д.А., Дворецький Т.В., Дідух Я.П., Жмуд О.І., Козир М.С., Конішук В.В., Куземко А.А., Пашкевич Н.А., Рифф Л.Е., Соломаха В.А., Фельбаба-Клушина Л.М., Фіцайло Т.В., Чорна Г.А., Чорней I.I., Шеляг-Сосонко Ю.Р., Якушенко Д.М. 2019. Продромус рослинності України. Ред. Д.В. Дубина, Т.П. Дзюба. Київ: Наукова думка, 782 с.].

Ehlers J., Gibbard P. 2011. Quaternary Glaciation. In: Encyclopedia of Snow, Ice and Glaciers. Encyclopedia of Earth Sciences Series. Eds V.P. Singh, P. Singh, U.K. Haritashya. Dordrecht: Springer, pp. 873882. https://doi.org/10.1007/978-90-481-2642-2_423

Euro+Med PlantBase - the information resource for EuroMediterranean plant diversity. 2006-onward. Available at: http://ww2.bgbm.org/EuroPlusMed/ (Accessed 16 August 2019).

Gajewski W. 1937. Elementy flory polskiego Podola. Planta Polonica, 5: 1-210.

IEU. Internet Encyclopedia of Ukraine. 2019. Available at: http://www.encyclopediaofukraine.com/default.asp (Accessed 30 July 2019).

Klokov M.V. 1955. Violaceae. In: Flora URSR, vol. 7. Eds M.V. Klokov, O.D. Visyulina. Kyiv: Vydavnytstvo Akademii nauk Ukrayinskoyi RSR, pp. 337-382. [Клоков М.В. 1955. Фіалкові - Violaceae Juss. В кн.: Флора УРСР, т. 7. Ред. М.В. Клоков, О.Д. Вісюліна. Київ: Видавництво Академії наук Української РСР, c. 337-382].

Koczwara M. 1931. Zespoły stepowe Podola Pokuckiego. Prace Instytutu Geografii im. E. Romera, 12: 35-79.

Kukovitsia H.S., Movchan Ya.I., Solomakha V.A., ShelyagSosonko Yu.R. 1994. Ukrainian Botanical Journal, 51 (2-3): 35-48. [Куковиця Г.С., Мовчан Я.І., Соломаха В.А., Шеляг-Сосонко Ю.Р. 1994. Синтаксономія лучних степів Західного Поділля (Україна). Український ботанічний журнал, 51(2-3): 35-48].

Mucina L., Bültmann H., Dierssen K., Theurillat J.-P., Raus T., Čarni A., Šumberová K., Willner W., Dengler J., Gavilán García R., Chytrý M., Hájek M., Di Pietro R., Iakushenko D., Pallas J., Daniëls F.J.A., Bergmeier E., Santos Guerra A., Ermakov N., Valachovič M., Schaminée J.H.J., Lysenko T., Didukh Ya.P., Pignatti S., Rodwell J.S., Capelo J., Weber H.E., Solomeshch A., Dimopoulos P., Aguiar C., Hennekens S.M., Tichý L. 2016. Vegetation of Europe: hierarchical floristic classification system of vascular plant, bryophyte, lichen, and algal communities. Applied Vegetation Science, 19 (Suppl. 1): 3-24. https://doi.org/10.1111/avsc.12257

Niketić M., Cikovac P., Barina Z., Pifkó D., Melovski L., Dukari S., Tomović G. 2015. Viola chelmea and Viola jooi (Violaceae), new species for the flora of Serbia and their distribution in the Balkan Peninsula and the Carpathians. Bulletin of the Natural History Museum, 8: 49-74. https:// doi.org/10.5937/bnhmb1508049N 
Nikitin V.V. 1996. Violaceae. In: Flora Europae Orientlis, vol. 9. Ed. N.N. Tzvelev. St. Petersburg: Mir i Semya-95, pp. 180-206. [Никитин В.В. 1996. Violaceae. В кн.: Флора Восточной Eвропы, т. 9. Ред. Н.Н. Цвелев. Санкт-Петербург: Мир и Семья-95, с. 180-206].

Novikoff A., Hurdu B.-I. 2015. A critical list of endemic vascular plants in the Ukrainian Carpathians. Contribuţii Botanice, 50: 43-91.

Oltean M., Negrean G., Popescu A., Roman N., Dihoru G., Sanda V., Mihăilescu S. 1994. Studii, sinteze, documentaţii de ecologie. Lista roșie a plantelor superioare din România. Bucureşti: Academia Română, Institutul de Biologie, $52 \mathrm{pp}$.

Roleček J., Hájek M., Dřevojan P., Prokešová H., Fajmon K., Těšitel J., Daněk P., Hájková P., Jongepierová I., Novák P., Poluyanov A.V., Shumska N.V., Chorney I.I. 2019. Gradients, species richness and biogeographical links of steppe grasslands in Western Podolia (Ukraine). Phytocoenologia, in press. https://doi.org/10.1127/ phyto/2019/0255

Shelyag-Sosonko Yu.R., Didukh Ya.P., Kukovitsia H.S. 1980. Ukrainian Botanical Journal, 37(3): 221-224. [Шеляг-Сосонко Ю.Р., Дідух Я.П., Куковиця Г.С. 1980. Поширення Viola jooi Janka на Україні. Український ботанічний журнал, 37(3): 221-224].

Solomakha V.A. 2008. Syntaksonomiya roslynnosti Ukrainy. Tretye nablyzhennya (Syntaxonomy of vegetation of Ukraine. Third approximation). Kyiv: Fitosotsiotsentr, 296 pр. [Соломаха В.А. 2008. Синтаксономія рослинності України. Третє наближення. Київ: Фітосоціоцентр, 296 с.].

Szafer W. 1923. Trzeciorzędowe rośliny górskie na wale scytyjskim w ostoi podolsko-wołyńskiej. Acta Societatis Botanicorum Poloniae, 1: 97-119.
Šmarda P. 2005. Biosystematická studie středoevropských kostřav Festuca ser. Psammophilae Pawlus: Ph. D. Diss. Brno, Masaryk University, 192 pp.

Thiers B. 2008-onward. Index Herbariorum. A global directory of public herbaria and associated staff. New York Botanical Garden's Virtual Herbarium. Available at: http:// sweetgum.nybg.org/science/ih Available at: http://sweetgum.nybg.org/science/ih/ (Accessed 16 August 2019).

Tutin T.G., Heywood V.H., Burges N.A., Moore D.M., Valentine D.H., Walters S.M., Webb D.A. 1976. Flora Europaea, vol. 4. Plantaginaceae to Compositae (and Rubiaceae). Cambridge: Cambridge University Press, $505 \mathrm{pp}$.

Valachovič M., Dierssen K., Dimopoulos P., Hadač E., Loidi J., Mucina L., Rossi G., Valle Tendero F., Tomaselli M. 1997. The vegetation on screes - a synopsis of higher syntaxa in Europe. Folia Geobotanica et Phytotaxonomica, 32(2): 173-192. https://doi. org/10.1007/BF02803739

Vashchenko V.O., Turchynova S.M., Turchynov I.I. 2007. Geological map and map of mineral resources of preQuaternary sediments. Carpathian Series. $M-35-X X V$ (Ivano-Frankivsk). Kyiv: Ukrainian State Geological Research Institute.

Zabłocki J. 1947. Flora Polska. Rośliny naczyniowe Polski $i$ ziem ościennych, vol. 6. Dwuliścienne. Wolnopłatkowe: Dwuokwiatowe. Rodzina: Violaceae, Fiołkowate. Krakow: Polska Akademia Umiejętności, $70 \mathrm{~s}$.

Zaverukha B.V. 1985. Flora Volyno-Podolii i ee genezis. Kiev: Naukova Dumka, 192 pp. [Заверуха Б.В. 1985. Флора Волыно-Подолии и ее генезис. Киев: Наукова думка, 192 c.].

Recommended for publication by Ya.P. Didukh 


\title{
Репрезентованість Pinus cembra (Pinaceae) в природно-заповідному фонді України
}

\author{
Сергій Ю. ПОПОВИЧ, Наталія В. МИХАЙЛОВИЧ, Тетяна С. ГРИСЮК
}

Національний університет біоресурсів і природокористування України вул. Генерала Родимцева 19, Київ 03041, Україна n8u5k0@ukr.net

Popovych S.Yu., Mykhaylovych N.V., Hrysiuk T.S. 2019. Representativity of Pinus cembra (Pinaceae) in natural protected fund of Ukraine. Ukrainian Botanical Journal, 76(6): 533-541.

National University of Life and Environmental Sciences of Ukraine 19 Henerala Rodimtseva Str., Kyiv 03041, Ukraine

n8u5k0@ukr.net

Abstract. Due to anthropogenic impact on vegetation cover, importance of the outphytosozological studies of coniferous plants of the Ukrainian Carpathians is emphasized. Pinus cembra is one of the rare species of trees in Europe and its in situ and ex situ conservation in Ukraine is required. At present, P. cembra is under protection in its natural habitats within 25 objects of the nature reserve fund of Ukraine and 71 objects of artificial plantations (in total of 10 categories). The network of the protected areas consists of two biosphere reserves, one nature reserve, six national nature parks, one regional landscape park, eight reserves (of which five are botanical), 13 botanical nature monuments, seven protected forest parcels, 14 botanical gardens, 16 dendrological parks, and 21 monuments of landscape art. The largest natural plant communities of $P$. cembra are located in Gorgany Nature Reserve (539 ha). As a result of the inventory studies, the boundaries of its cultivation area in Ukraine were defined. It is obvious that the most widespread cultivation of $P$. cembra is within the Carpathian Mountains (20 objects). The Forest-Steppe zone of Ukraine and the zone of deciduous forests of Ukraine (14 and 16 objects, respectively) provide sufficiently suitable ecological conditions for cultivation of $P$. cembra. The least number of artificial plantations under protection were found in the Mixed Forest zone (4) and the Steppe zone of Ukraine (6 objects). The largest number of the protected natural forests (16) and artificial plantations (11 objects) was registered in Ivano-Frankivsk Region. Plants aged ca. 250 years were revealed under artificial conditions (in cultivation).

Keywords: area of plant species, ex situ, in situ, natural geographic regions, Pinus cembra, protection of plant species, reserved localites

Submitted 03 October 2018. Published 29 December 2019

Попович С.Ю., Михайлович Н.В., Грисюк Т.С. 2019. Репрезентованість Pinus cembra (Pinaceae) у природно-заповідному фонді України. Український ботанічний журнал, 76(6): 533-541.

Реферат. Узв'язкузантропічними змінами рослинногопокриву акцентується увага наактуальностіаутфітосозологічних досліджень хвойних рослин Українських Карпат. Актуальним для України є збереження і збагачення in situ та ex situ одного із раритетних видів деревних рослин Європи - Pinus cembra. Описується його сучасний, достатньо високий рівень репрезентованості заповідання в Україні. В аспекті категоріальної та об'єктної репрезентативності природні місцезнаходження $P$. сетbra охороняються в межах 25 об'єктів ПЗФ, а штучні насадження - у межах 71 об'єкта, які загалом належать до 10 категорій. Мережу територій та об'єктів природно-заповідного фонду збереження виду складають 2 біосферні заповідники, 1 природний заповідник, 6 національних природних парків, 1 регіональний ландшафтний парк, 8 заказників, з яких 5 ботанічних, 13 ботанічних пам'яток природи, 7 заповідних урочищ, 14 ботанічних садів, 16 дендрологічних парків та 21 парк-пам'ятка садово-паркового мистецтва. Найбільші площі фітоценозів P. cembra сконцентровані в природному заповіднику "Горгани" (539 га). У результаті інвентаризаційних досліджень уточнено межі культигенного ареалу цього виду в Україні. Закономірним явищем $€$ широке культивування рослин у Карпатській гірській країні (20 об'єктів). Близькими й достатньо придатними за екоумовами для культивування Pinus cembra є лісостепова зона України (14 об'єктів) і зона широколистяних лісів України (16 об'єктів). Найменше штучних охоронних об'єктів виявлено у зоні мішаних лісів (4) та степовій зоні України (6). Найбільша кількість заповідних природних (16) і штучних (11) об'єктів цього виду зареєстрована в Івано-Франківській області. У штучних умовах виявлено рослини віком близько 250 років.

Ключові слова: заповідні локалітети, культигенний ареал виду рослин, охорона видів рослин, природно-географічні регіони, ex situ, in situ, Pinus cembra

(C) 2019 S.Yu. Popovych, N.V. Mykhaylovych, T.S. Hrysiuk. Published by the M.G. Kholodny Institute of Botany, NAS of Ukraine. This is an open access article under the terms of the Creative Commons Attribution License (http://creativecommons.org/licenses/by/4.0/), which permits use, distribution, and reproduction in any medium, provided the original work is properly cited

Український ботанічний журнал, 2019, 76(6) 


\section{Вступ}

У лісовій зоні України, особливо в гірських екосистемах Українських Карпат, все глибшою стає деградація рослинного покриву, передусім фітоценозів хвойних лісів, едифікатори яких не витримують конкуренції 3 автохтонними листяними, а в низовині - 3 експансивними інтродукованими видами деревних рослин. Такі тенденції простежуються навіть на деяких незначної площі територіях та об'єктах природнозаповідного фонду (ПЗФ). Від нестачі вологи фрагментарно всихають й корінні хвойні приполонинські ліси. За нашими багаторічними спостереженнями в Горганах у верхньому басейні річки Тереблі ресурс приповерхневого водоносного горизонту майже вичерпався. Нині тут основний водоносний горизонт залягає на глибині 8-9 м.

Такі ознаки тенденції гологенетичних змін у рослинному покриві інших природно-географічних регіонів описані в літературі (Convention..., 1979; Global..., 1995; Walter, Gillett, 1997; Hawkes et al., 2000; Magurran, 2004), в якій наголошується на необхідності врятувати, насамперед, раритетні види рослин. В умовах масштабних антропічних змін їхне зникнення спричинюе порушення цілісності природних екосистем на всіх рівнях їхньої організованості. Це позначається на повноті функціонування генетичної, популяційної, фітоценотичної та оселищної різноманітності раритетних видів рослин.

Для призупинення деградації флори й рослинності найважливішим $€$ збереження популяцій кожного раритетного виду рослин та його функцій в екосистемі, оскільки він володіє неповторним генетичним надбанням, сформованим у результаті природного відбору. Зважаючи на незворотність антропічної трансформації хвойних лісів Українських Карпат, особливо актуальним для України є збереження одного із раритетних видів деревних рослин Европи - Pinus cembra L. in situ та ex situ шляхом формування оптимальної мережі заповідних природних і штучних об'єктів, насамперед лісових культур, та збільшення чисельності його особин. Вид близько 90 років досліджується в світі та Україні, в останні 40 років його вивчення стало більш різнобічним (Contini, Lavarelo, 1982; Tasenkevich, 1998; Borlea et al., 2006; Höhn et al., 2009; Chernevyi et al, 2011; Saulnier et al., 2011; Heinze1, Holzer, 2013; Sirenko et al.,
2014). Безперечно, основною причиною зникання цього виду є антропічна діяльність у горах на тлі кліматичних змін.

Pinus cembra - середньоєвропейський монтанний плейстоценовий релікт, який в автохтонних умовах поширений в Альпах та Карпатах у верхньому лісовому та нижній частині субальпійського поясів (Tasenkevich et al., 2009). Вид включено до Червоного списку Міжнародного союзу охорони природи (категорія LC ver. $3.1-$ перебуває під невеликою загрозою станом на 2018 рік). У Червоній книзі України значиться як вразливий (Tasenkevich et al., 2009). Цей вид виступає співдомінантом раритетних фітоценозів карпатських кедрових європейськососнових лісів, які внесені до Зеленої книги України (Zelena knyha..., 2009), а разом з європейськомодриновими лісами - до Бернської конвенції (Konventsiya..., 1998; Metodychni..., 2008). За палеарктичною класифікацією лісам надано код 42.35.

\section{Матеріали та методи досліджень}

Об'єктом дослідження слугувала мережа заповідних територій, на яких відмічені місця природного зростання та/або штучні насадження $P$. cembra в Україні. Предметом дослідження був аналіз представленості цього виду на територіях ПЗФ в адміністративних областях, а також у межах рівнинних фізико-географічних зон та гірської країни (Marynych et al., 2003) України. Поширення P. cembra у природних умовах Українських Карпат добре висвітлено у вітчизняній літературі (Stoyko, 1966, 1977; Stoyko et al., 1980, 2004; Tasenkevich, 1998; Didukh et al., 2000; Krynytskyi et al., 2000; Patsura, 2000; Oleksiv et al., 2004; Sivak et al., 2004; Sirenko, 2008; Tasenkevich et al., 2009). Метою наших досліджень було встановлення сучасного рівеня репрезентованості виду на територіях ПЗФ України загалом. Для цього опрацьовували наукову і довідкову літературу (Stoyko, 1966, 1977; Stoyko et al., 1980; Chorney et al., 2005; Klimuk et al., 2006; Dendrosozolohichnyi..., 2011, 2014, 2017; Derzhypilskyi et al., 2011; Tyukh et al., 2011). На основі отриманої інформації було найповніше після О.Г. Сіренко (Sirenko, 2008) визначено розмірність заповідного природного та культигенного ареалів цього виду в Україні за винятком Кримських гір, де в каталогах рослин установ ПЗФ цей вид не наводиться. Отримана нами інформація вкрай 
важлива для підготовки четвертого видання Червоної книги України.

\section{Результати та обговорення}

Як відомо, $P$. cembra охороняється на багатьох природно-заповідних територіях, наприклад: у Румунії- в національних парках "Ретезат" і "Родна", в Австрії - у біосферному резерваті "Нокберге", національних парках "Гоге Тоуерн", "Гезайзе" тощо (Contini, Lavarelo, 1982; Borlea et al., 2006).

Проблема збереження $P$. cembra в Україні порушувалася з кінця ХІХ століття. Проте, перший резерват в Українських Карпатах "Горгани" був створений у верхів'ї річки Лімниці біля с. Ясень у 1919 р. на площі 178 га, яку згодом розширили до 2589 га. В 1935 році тут в урочищі Яйце заснували "Кедринськийзаповідник" площею 255,19га, ачерез два роки в околицях гори Грофа - Український парк природи на площі 1800 га. Для збереження P. cembra у 1930-х роках було організовано державний заказник "Тавпіширківський" (583,85 га), який став територіальною основою для створення природного заповідника "Горгани". В 1972 р. у межах міської ради Яремче Івано-Франківської області було створено ботанічні пам'ятки природи місцевого значення "Сосна кедрова європейська" (0,02 га) та "Резерват сосни кедрової європейської" $(8,9$ га), які увійшли до складу території Карпатського національного природного парку (НПП). Уже в 1970-х роках площа деревостанів з участю $P$. cembra на охоронюваних територіях становила понад 6 тис. га. Шість об'єктів, на яких було виявлено цей вид, взято під охорону в 1974 році, п'ять з них заповідано в 1996 р.

Загалом нині на території Українських Карпат відомо близько 135 природних локалітетів P. cembra. Вони переважно зосереджені на схилах різних експозицій (здебільшого західних і південнозахідних) на площі близько 3000 га і висоті 12001630 м над р. м. на території Івано-Франківської та Закарпатської областей (Stoyko, 1966, 1977; Stoyko et al., 1980, 2004; Klimuk et al., 2006; Sirenko, 2008; Tasenkevich, Melnyk, Sirenko, 2009; Chernevyi et al., 2011).

Важливим аспектом в охороні раритетних видів рослин є надійність їхнього збереження від діяльності людини. Безперечно, такими осередками надійності виступають території ПЗФ значної площі, передусім заповідники та національні природні парки. Монодомінантні Український ботанічний журнал, 2019, 76(6) та мішані 3 участю $P$. cembra фітоценози нині на найбільших площах (539 га) охороняються у природному заповіднику "Горгани", де формують найпоширенішу серед інших асоціацію Pineto (cembrae)-Piceetum (abietis) vaccinioso (myrtilli)-pleuroziosum (schreberi). Деревостани 3 переважанням рослин цього виду займають тут близько 80 га, але поновлюються погано. Ростуть на сирих і сухих неглибоких кам'янистих злегка оторфованих буроземах (Klimuk et al., 2006).

Надійно захищеними є місцезростання $P$. cembra у Карпатському біосферному заповіднику, "Карпатському" НПП, "Черемоському" НПП (в його складі однойменний регіональний ландшафтний парк), НПП "Гуцульщина" та "Синевир", у межах яких вид відомий з кількох або поодиноких локалітетів. За рівнем суворості режиму збереження близькими до природних заповідників є заповідні урочища, де $P$. cembra офіційно має бути забезпечений абсолютним заповідним режимом, однак він не завжди витримується. Менш захищений цей вид у заказниках. Так, О.Г. Сіренко (Sirenko, 2008) вважає, що суцільні деревостани, в т. ч. й пралісові, з участю цього виду зникли в заказниках "Попадя", "Тавпіширківський", заповідних урочищах "Салатрук", "Райфаловець", "Тавпіширка" та "Вижній Кедринець". Разом 3 цим, у загальній системі видової охорони особливу увагу слід надавати збереженню вікових деревних рослин. Поодинокі або такі, що ростуть групами багатовікові дерева $P$. cembra охороняються в статусі ботанічних пам'яток природи. Старовікові, навіть 750-річні дерева, ростуть і на території багатьох об'єктів інших категорій ПЗФ.

Враховуючи швидкі темпи зникнення рослин P. cembra 3 природного середовища, одним iз альтернативних способів збереження виду є їхнє штучне вирощування, насамперед, на територіях об'єктів ПЗФ. Перші спроби інтродукції виду в лісостеповій зоні України було проведено в 1862 р. у с. Молочки Житомирської області (Sirenko, 2008). Оскільки головну роль у збереженні рослинного різноманіття відіграють ботанічні сади та дендрологічні парки, то в багатьох 3 них, в колекціях, є рослини цього виду. Усі відомі нам заповідні території, на яких є місця природного зростання рослин $P$. cembra та його штучні насадження наведено в таблиці.

Отже, в результаті наших інвентаризаційних досліджень встановлена значна представленість 
Таблиця. Заповідні території України, на яких охороняється Pinus cembra

Table. Pinus cembra in natural protected areas of Ukraine

\begin{tabular}{|c|c|c|c|c|}
\hline \multirow{2}{*}{$\begin{array}{l}\text { Території та об'єкти } \\
\text { ПЗФ України }\end{array}$} & \multirow{2}{*}{$\begin{array}{c}\text { Місця } \\
\text { природного } \\
\text { зростання }\end{array}$} & \multirow{2}{*}{$\begin{array}{c}\text { Штучні } \\
\text { насадження }\end{array}$} & \multicolumn{2}{|r|}{ Регіони } \\
\hline & & & $\begin{array}{c}\text { фізико- } \\
\text { географічні* }\end{array}$ & адміністративні, область/місто \\
\hline \multicolumn{5}{|c|}{ Біосферні заповідники } \\
\hline Карпатський & + & + & УK & Закарпатська \\
\hline \multicolumn{5}{|c|}{ Природні заповідники } \\
\hline "Горгани" & + & + & УK & Івано-Франківська \\
\hline \multicolumn{5}{|c|}{ Національні природні парки } \\
\hline "Вижницький" & - & + & УK & Чернівецька \\
\hline "Гуцульщина" & + & + & УK & Івано-Франківська \\
\hline Карпатський & + & + & yK & Івано-Франківська \\
\hline "Синевир" & + & + & УK & Закарпатська \\
\hline Черемоський & + & - & УK & Чернівецька \\
\hline Шацький (дендрарій коледжу) & - & + & ЗМл & Волинська \\
\hline \multicolumn{5}{|c|}{ Регіональні ландшафтні парки } \\
\hline Черемоський (Черемоський НПП) & + & - & yK & Чернівецька \\
\hline \multicolumn{5}{|c|}{ Заказники } \\
\hline \multicolumn{5}{|c|}{ ботанічні } \\
\hline "Горгани і Тавпіширка" & + & + & уK & Закарпатська \\
\hline Кедринський & + & - & уK & Закарпатська \\
\hline Тавпіширківський & + & - & уK & Івано-Франківська \\
\hline "Урочища Странзул, Задня і Кедрин" & + & - & yK & Закарпатська \\
\hline Яйківський & + & - & УK & Івано-Франківська \\
\hline \multicolumn{5}{|c|}{ ландшафтні } \\
\hline Брадульський & + & - & УK & Закарпатська \\
\hline "Грофа" & + & - & УK & Івано-Франківська \\
\hline \multicolumn{5}{|c|}{ лісові } \\
\hline "Урочище Погорілець" & + & - & $\mathrm{yK}$ & Івано-Франківська \\
\hline \multicolumn{5}{|c|}{ Пам'ятки природи } \\
\hline \multicolumn{5}{|c|}{ ботанічні } \\
\hline "Горган" & + & - & yK & Івано-Франківська \\
\hline "Група рідкісних дерев" (1) & - & + & ПК & Чернівці \\
\hline "Група рідкісних дерев" (2) & - & + & ПК & Чернівці \\
\hline "Кедр європейський" (1) & - & + & ПК & Чернівці \\
\hline "Кедр європейський" (2) & - & + & ПК & Чернівці \\
\hline "Кедр європейський" (3) & - & + & УK & Закарпатська \\
\hline Кедр європейський (4) & - & + & $\mathrm{yK}$ & Закарпатська \\
\hline $\begin{array}{l}\text { "Кедр європейський" (5) } \\
\text { (Карпатський біосферний заповідник) }\end{array}$ & - & + & уK & Закарпатська \\
\hline "Кропивник" & + & + & yK & Івано-Франківська \\
\hline "Правич-1" & + & - & $\mathrm{yK}$ & Івано-Франківська \\
\hline "Правич-2" & + & - & yK & Івано-Франківська \\
\hline "Сосна кедрова" & - & + & УK & Івано-Франківська \\
\hline
\end{tabular}




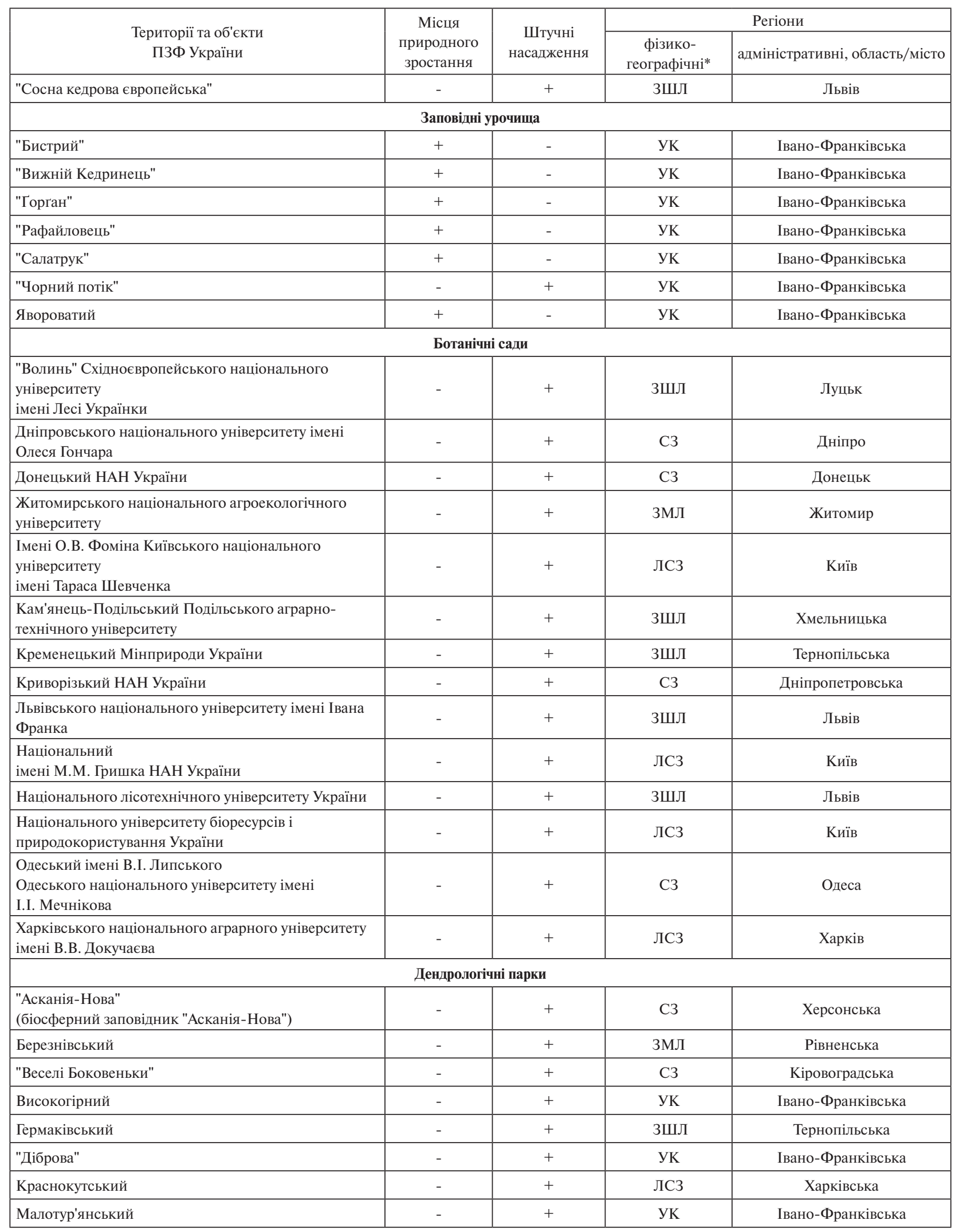




\begin{tabular}{|c|c|c|c|c|}
\hline \multirow{2}{*}{$\begin{array}{c}\text { Території та об'єкти } \\
\text { ПЗФ України }\end{array}$} & \multirow{2}{*}{$\begin{array}{c}\text { Місця } \\
\text { природного } \\
\text { зростання }\end{array}$} & \multirow{2}{*}{$\begin{array}{c}\text { Штучні } \\
\text { насадження }\end{array}$} & \multicolumn{2}{|r|}{ Регіони } \\
\hline & & & $\begin{array}{c}\text { фізико- } \\
\text { географічні* }\end{array}$ & адміністративні, область/місто \\
\hline "Олександрія" & - & + & ЛСЗ & Київська \\
\hline Сирецький & - & + & ЛСЗ & Київ \\
\hline "Тростянець" & - & + & ЛСЗ & Чернігівська \\
\hline Устимівський & - & + & ЛСЗ & Полтавська \\
\hline $\begin{array}{l}\text { Харківського національного аграрного університету } \\
\text { імені В.В. Докучаєва }\end{array}$ & - & + & ЛСЗ & Харківська \\
\hline Хоростківський & - & + & ЗШЛ & Тернопільська \\
\hline \multicolumn{5}{|c|}{ Парки-пам'ятки садово-паркового мистецтва } \\
\hline Більче-Золотецький & - & + & ЗШЛ & Тернопільська \\
\hline Верхівнянський & - & + & ЛСЗ & Житомирська \\
\hline "Дендрарій лісодослідної станції" & - & + & ЛСЗ & Вінницька \\
\hline "Дендропарк імені 40-річчя Перемоги" & - & + & УК & Івано-Франківська \\
\hline "Жевахівщина" & - & + & ЛСЗ & Чернігівська \\
\hline Загінецький & - & + & ЗШЛ & Хмельницька \\
\hline Згурівський & - & + & ЛСЗ & Київська \\
\hline "Івківці" & - & + & ЛС3 & Чернігівська \\
\hline "Парк радгоспу Партизан" (Криворудський) & - & + & ЛСЗ & Полтавська \\
\hline "Парк санаторію Карпати" & - & + & УК & Закарпатська \\
\hline "Парк-арборетум" & - & + & УK & Закарпатська \\
\hline "Поділля" & - & + & ЗШЛ & Хмельницький \\
\hline Самчиківський & - & + & ЗШЛ & Хмельницька \\
\hline Тиницький & - & + & ЛС3 & Чернігівська \\
\hline
\end{tabular}

*3МЛ - зона мішаних лісів, ЗШЛ - зона широколистяних лісів, ЛС3 - лісостепова зона, ПК - Передкарпаття, С3 степова зона, УК - Українські Карпати. 
P. cembra на територіях ПЗФ України. У межах ареалу природні місцезростання виду охороняються в Карпатах, переважно в Івано-Франківській та Закарпатській областях, у 25 заповідних об'єктах, які належать до всіх 7 категорій природнозаповідних територій.

Закономірним $є$ широке культивування рослин у межах української частини природного ареалу виду, тобто в Карпатській гірській країні (20 об'єктів). Проте, ми встановили ширшу, ніж передбачалося, представленість виду на територіях ПЗФ у межах культигенного ареалу. На жаль, вид не вирощується в провідних ботанічних садах Ужгорода та Чернівців. У зоні широколистяних лісів та лісостеповій зоні виявлено 16 та 14 локалітетів штучних насаджень на територіях ПЗФ відповідно. Найменше об'єктів, на територіях яких вирощується $P$. cembra, виявлено у степовій зоні (6) та зоні мішаних лісів (4), що значною мірою обумовлено менш придатними екоумовами цих фізико-географічних регіонів для вирощування рослин дослідженого виду.

\section{Висновки}

Загальний рівень репрезентованості виду на територіях ПЗФ України достатньо високий, природні місцезнаходження $P$. cembra охороняються в межах 25 об'єктів ПЗФ, штучні насадження - в межах 71 об'єкта, які загалом належать до 10 категорій. Мережу складають 2 біосферні заповідники, 1 природний заповідник, 6 національних природних парків, 1 регіональний ландшафтний парк, 8 заказників, 3 яких 5 ботанічних, 13 ботанічних пам'яток природи, 7 заповідних урочищ, 14 ботанічних садів різного підпорядкування, 16 дендропарків та 21 паркпам'ятка садово-паркового мистецтва. Вид не представлений лише в зоопарках. Найбільші площі його фітоценозів сконцентровано в природному заповіднику "Горгани" (539 га). У природних умовах охороняються дерева віком до 750 років, а в штучних насадженнях - до 250 років. Окрім Українських Карпат, вид добре забезпечений охороною в межах культигенного ареалу - у лісостеповій зоні та зоні широколистяних лісів України, значно гірше у степовій зоні та зоні мішаних лісів. На територіях ПЗФ найбільше (17) природних локалітетів P. cembra виявлено в Івано-Франківській області, у межах якої також найбільша кількість (13) його штучних насаджень.

Український ботанічний журнал, 2019, 76(6)

\section{СПИСОК ПОСИЛАНЬ}

Borlea G.F., Radu S., Stana D. 2006. Forest biodiversity preservation of Romania. Notulae Botanicae Horti Agrobotanici Cluj-Napoca, 34: 21-27.

Chernevyi Yu.I., Tretyak P.R., Savchyn A.I. 2011. Naukovyi visnyk NLTU Ukrainy, 21.11: 54-61. [Черневий Ю.I., Третяк П.Р., Савчин А.І. 2011. Особливості росту дерев сосни кедрової (Pinus cembra L.) у верхів"ї басейну ріки Лімниці у Карпатах. Науковий вісник НЛТУ, 21.11: 54-61].

Chorney I.I., Budzhak V.V., Yakuschenko D.M., Korzhyk V.P., Solomakha V.A., Sorokan Yu.I., Tokaryuk A.I., Solomakha T.D. 2005. Naturale reserve territories of Ukraine. Plant world, issue 4. Kyiv: Phytosociocentre, 248 pp. [Чорней I.I., Буджак B.В., Якушенко Д.М., Коржик В.П., Соломаха В.А., Сорокан Ю.І., Токарюк А.І., Соломаха Т.Д. 2005. Природно-заповідні території України. Рослинний світ, вип. 4. Київ: Фітосоціоцентр, 248 с.].

Contini L., Lavarelo J. 1982. Le pin cembro Pinus cembra L. Paris: INRA, $197 \mathrm{pp}$.

Convention of the European Wildlife and Natural Habitats. 1979. Bern, $75 \mathrm{pp}$.

Dendrosozolohichnyi kataloh pryrodno-zapovidnoho fondu Lisostepu Ukrayiny (The dendrosozological catalogue of natural-protected fund of the Forest-steppe of Ukraine). 2011. Ed. S.Yu. Popovych. Kyiv: Agrar Media Grup, 800 pp. [Дендросозологічний каталог природно-заповідного фонду Лicocmeny України. 2011. Під ред. С.Ю. Поповича. Київ: Аграр Медіа Груп, 800 с.].

Dendrosozolohichnyi kataloh pryrodno-zapovidnoho fondu Stepu Ukrayiny. Ed. S.Yu. Popovych. 2014. Kyiv: Komprynt, 888 pp. [Дендросозологічний каталог природно-заповідного фонду Степу Украӥни. 201. За ред. С.Ю. Поповича. Київ: Компринт, 888 с.].

Dendrosozolohichnyi kataloh pryrodno-zapovidnoho fondu Ukrainskoho Polissya. 2017. Ed. S.Yu. Popovych. Kyiv: Komprynt, 466 pp. [Дендросозологічний каталог природно-заповідного фонду Українського Полісся. 2017. За ред. С.Ю. Поповича. Київ: Компринт, 466 с.].

Derzhypilskyi L.M., Tomych M.V., Yusyp S.V., Losyuk V.P., Yakuschenko D.M., Danylyk I.M., Chorney I.I., Budzhak V.V., Kondratyuk S.Ya., Nyporko S.O., Virchenko V.M., Mikhailyuk T.I., Darienko T.M., Solomakha V.A., Prorochuk V.V., Stefurak Yu.P., Fokshey S.I., Solomakha T.D., Tokaryuk A.I. 2011. Naturale protected territories of Ukraine. Plant world, issue 9. Kyiv: Phytosociocentre, 360 pp. [Держипільський Л.М., Томич М.В., Юсип С.В., Лосюк В.П., Якушенко Д.М., Данилик I.М., Чорней I.I., Буджак В.В., Кондратюк С.Я., Нипорко С.О., Вірченко В.М., Михайлюк T.I., Дарієнко Т.М., Соломаха В.А., Пророчук В.В., Стефурак Ю.П., Фокшей С.І., Соломаха Т.Д., Токарюк А.I. 2011. Природно-заповідні території України. Рослинний світ, вип. 9. Київ: Фітосоціоцентр, 360 с.].

Didukh Ya.P., Yermolenko V.M., Kondratyuk S.Ya. 2000. Pinus cembra. In: Ekoflora Ukrainy (Ecoflora of Ukraine), vol. 1. Ed. Ya.P. Didukh. Kyiv: Phytosociocentre, pp. 232-233. [Дідух Я.П., Єрмоленко В.М., Кон- 
дратюк С.Я. 2000. Pinus cembra L. В кн.: Екофлора України, т. 1. Відпов. ред. Я.П. Дідух. Київ: Фітосоціоцентр, с. 232-233].

Global Biodiversity Assesment. 1995. Eds V.H. Heywood, R.T. Watson. Cambridge: University Press, 1140 pp.

Hawkes J.G., Maxted N., Ford-Lloyd B.V. 2000. The ex situ Conservation of Plant Genetic Resources. Netherlands: Springer Science+Business Media. B.V., 249 pp.

Heinze1 B., Holzer K. 2013. A review of research on Pinus cembra in Austria, with special reference to the conservation of genetic resources. In: $5^{\text {th }}$ Symposium Conference Volume for Research in Protected Areas. Mittersill: Conference Volume, pp. 279-283.

Höhn M., Gugerli F., Abran P., Bisztray G., Buonamici A., Cseke K., Hufnagel L., Quintela-Sabarís C., Sebastiani F., Vendramin G.G. 2009. Variation in the chloroplast DNA of Swiss stone pine (Pinus cembra L.) reflects contrasting post-glacial history of populations from the Carpathians and the Alps. Journal of Biogeography, 36: 1798-1806.

Klimuk Yu.V., Miskevych U.D., Yakuschenko D.M., Chorney I.I., Budzhak V.V., Nyporko S.O., Shpilchak M.B., Chernyavsky M.V., Tokaryuk A.I., Oleksiv T.M., Tymchuk Ya.Ya., Solomakha V.A., Solomakha T.D., Mayor R.V. 2006. Naturale reserve territories of Ukraine. Plant world, issue 6. Kyiv: Phytosociocentre, 400 pp. [Клімук Ю. В., Міскевич У.Д., Якушенко Д.М., Чорней I.І., Буджак В.В., Нипорко С.О., Шпільчак М.Б., Чернявський М.В., Токарюк А.І., Олексів Т.М., Тимчук Я.Я., Соломаха В.А., Соломаха Т.Д., Майор Р.В. 2006. Природно-заповідні території Украӥни. Рослинний світ, вип. 6. Київ: Фітосоціоцентр, 2006, 400 с.].

Konventsiya pro okhoronu dykoyi flory i fauny ta pryrodnykh seredovyshch isnuvannya v Europi (Bern, 1979). 1998. Kyiv: Minekobezpeky Ukrainy, 76 pp. [Конвенція про охорону дикої флори і фауни та природних середовищ існування в Европі (Берн, 1979). 1998. Київ: Мінекобезпеки України, 76 с.].

Krynytskyi H.T., Kuziv R.F., Kishchenko D.A. 2000. In: National Natural Parks: problems of creation and development: Proceedings of the international scientificpractical conference, dedicated to the $20^{h}$-anniversary of the Carpathian National Natural Park. Yaremche, pp. 177-181. [Криницький Г.Т., Кузів Р.Ф., Кіщенко Д.А. 2000. Сосна кедрова європейська в Українських Карпатах: поширення, проблеми збереження і відтворення. У зб.: Національні природні парки: проблеми становлення та розвитку: матеріали міжнародної науково-практичної конференції, присвяченої 20-річчю Карпатського національного природного парку (м. Яремче, 14-17 вересня, 2000 р.). Яремче, c. $177-181]$.

Magurran A.E. 2004. Measuring biological diversity. Oxford, UK: Blackwell Publishing, 256 pp.

Marynych O.M., Parkhomenko H.O., Petrenko O.M., Shyshchenko P.H. 2003. Ukrainian Geographical Journal, 41: 16-20. [Маринич О.М., Пархоменко Г.О., Петренко О.М., Шищенко П.Г. 2003. Удосконалена схема фізико-географічного районування України. Український географічний журнал, 41: 16-20].
Metodychni aspecty vprovadzhennya mizhnarodnoyi prohramy "vazhlyvi botanichni terytoriyi" v Ukrayini. 2008. Eds T.L. Andrienko, V.A. Onyshchenko. Kyiv: Aristey, 43 pp. [Методичні аспекти впровадження міжнародної програми "важсливі ботанічні території" в Україні. 2008. Під ред. Т.Л. Андрієнко, В.А. Онищенка. Київ: Арістей, 43 с.].

Oleksiv T.M., Klimuk Yu.V., Shpytko T.V. 2004. Zapovidna sprava v Ukraini, 10(1-2): 28-30. [Олексів Т.М., Клімук Ю.В., Шпитко Т.В. 2004. До питання формування фітоценозів з участю реліктової сосни кедрової в Горганах. Заповідна справа в Україні, 10(1-2): 28-30].

Patsura I.M. 2000. In: National Natural Parks: problems of creation and development. Proceedings of the international scientific-practical conference, dedicated to the $20^{\text {th }}$ anniversary of the Carpathian National Natural Park. Yaremche, pp. 114-116. [Пацура I.M. 2000. Поширення популяцій сосни кедрової (Pinus cembra L.) за межами природно-заповідного фонду Осмолодського ДЛГ. У зб.: Національні природні парки: проблеми становлення та розвитку: матеріали міжнародної науково-практичної конференції, присвяченої 20-річчю Карпатського національного природного парку (м. Яремче, 14-17 вересня, 2000 р.). Яремче, с. 114-116].

Saulnier M., Edouard J.-L., Corona Ch., Guibal F. 2011. Climate/growth relationships in a Pinus cembra highelevation network in the Southern French Alps. Annals of Forest Science, 68: 189-200.

Sirenko O.G. 2008. European cedar pine (Pinus cembra L.) in Ukrainian: distribution, structure of population and protection: Cand. Sci. Diss. Abstract. Kyiv, 2008, 23 pp. [Сіренко О.Г. 2008. Сосна кедрова європейська (Ріпиs сетbra L.) в Україні: хорологія, структура популяцій та охорона: автореф. дис. ... канд. біол. наук: спец. 03.00.05 "Ботаніка". Київ, 23 с.].

Sirenko O.H., Sirenko H.O., Kuzyshyn O.V., Midak L.Ya. 2014. Matematychni metody v khimii I biolohii, 2(1): 48-68. [Сіренко О.Г., Сіренко Г.О., Кузишин О.В., Мідак Л.Я. 2014. Загальний та кореляційний аналізи стану популяцій сосни кедрової європейської (Pinus cembra L.) в Українських Карпатах. Математичні методи в хімії і біології, 2(1): 48-68].

Sivak V.K., Solodkyy V.D., Korolyuk V.I., Bilokon' M.V. 2004. Bukovyna a reserved land. Chernivtsi: Zelena Bukovyna, 112 pp. [Сівак В.К., Солодкий В.Д., Королюк В.І., Білоконь М.В. 2004. Буковина - край заповідний. Чернівці: Зелена Буковина, 112 с.].

Stoyko S.M. 1966. Zapovidnyky ta pamyatky pryrody Ukrayinskykh Karpat. Lviv, 142 pp. [Стойко C.M. 1966. Заповідники та пам'ятки природи Українських Карnат. Львів, 142 с.].

Stoyko S.M. 1977. Karpatam zelenity vichno. Uzhgorod: Karpaty, 176 pр. [Стойко С.M. 1977. Карпатам зеленіти вічно. Ужгород: Карпати, 176 с.].

Stoyko S.M., Milkina L.I., Solodkova T.I., Zaets Z.S., Tasenkevich L.O., Zhyzhyn M.P. 1980. Okhorona pryrody Ukrayinskykh Karpat ta prylehlykh terytoriy. Kyiv: Naukova Dumka, 264 pp. [Стойко C.M., Мілкіна Л.I., Солодкова Т.І., Заєць 3.С., Тасенкевич Л.О., Жижин М.П. 1980. Охорона природи Украӥнських Кар- 
пат та прилеглих територій. Київ: Наукова думка, 264 c.].

Stoyko S.M., Yashchenko P.T., Kagalo O.O., Milkina L.I., Tasenkevich L.O., Zagulskyi M.M. 2004. Rarytetnyi fitogenofond zakhidnykh rehioniv Ukrayiny: sozologichna otsinka i naukovi zasady okhorony. Lviv: Liga-Pres, 232 pp. [Стойко С.М., Ященко П.Т., Кагало О.О., Мілкіна Л.І., Тасєнкевич Л.О., Загульський М.М. 2004. Раритетний фітогенофонд західних регіонів України: созологічна оцінка й наукові засади охорони. Львів: Ліга-Прес, 232 с.].

Tasenkevich L. 1998. Flora of the Carpathians. Checklist of the native vascular plant species. L'viv: State Museum of Natural History of NAS of Ukraine, $610 \mathrm{pp}$.

Tasenkevich L.O., Melnyk V.I., Sirenko O.G. 2009. Pinus cembra. In: Chervona knyha Ukrainy. Roslynnyi svit (Red Data Book of Ukraine. Plant Kingdom). Ed. Ya.P. Didukh. Kyiv: Globalkonsaltyng, p. 45. [Тасєнкевич Л.О.,
Мельник B.I., Сіренко О.Г. 2009. Pinus cembra. В кн.: Червона книга Украӥни. Рослинний світ. За ред. Я.П. Дідуха. Київ: Глобалконсалтинг, с. 45].

Tyukh Yu.Yu., Zyman S.M., Derbak M.Yu. 2011. Roslynnyy pokryv Natsionalnoho pryrodnoho parku "Synevyr" (Ukrayinski Karpaty). Uzhgorod: Lira, 160 pp. [Тюх Ю.Ю., Зиман С.М., Дербак М.Ю. 2011. Рослинний покрив Національного природного парку "Синевир" (Українські Карпати). Ужгород, 160 с.].

Walter K.S., Gillett H.J. 1998. IUCN Red List of Threatened Plants. Compiled by the World Conservation Monitoring Centre. IUCN - The World Conservation Union. Switzerland and Cambridge (UK), 862 pp.

Zelena knyha Ukrayiny. 2009. Ed. Ya.P. Didukh. Kyiv: Alterpress, 448 pp. [Зелена книга України. 2009. За ред. Я.П. Дідуха. Київ: Альтерпрес, 448 с.].

Рекомендує до друку I.А. Коротченко 


\title{
Galeopsis angustifolia (Lamiaceae) - новий адвентивний вид у флорі України
}

\author{
Олександр О. ОРЛОВ ${ }^{1}$, Дмитро М. ЯКУШЕНКО², Яна МАЕКОВА ${ }^{3}$, Марія ЗАЛІБЕРОВА, \\ Віра В. ПРОТОПОПОВА ${ }^{4,5}$, Сва Й. АНДРИК ${ }^{4}$, Мирослав В. ШЕВЕРА ${ }^{5,4}$
}

${ }^{1}$ Поліський філіал Українського НДІ лісового господарства та агролісомеліорації ім. Г.М. Висоцького НАН України та Держлісагентства України

вул. Нескорених 2, с. Довжик, Житомирський р-н 10004, Житомирська обл., Україна

orlov.botany@gmail.com

23еленогурський університет

вул. Шафрана 1, Зелена Гура 65-516, Польща

d.iakushenko@gmail.com

${ }^{3}$ Ботанічний інститут, Центр біології рослин та біорізноманіття Словацької АН

вул. Дубравська цеста 9, Братислава 84523, Словацька Республіка

jana.majekova@savba.sk; maria.zaliberova@savba.sk

4Закарпатський угорський інститут імені Ференца Ракоці II

пл. Кошута 6, Берегове 90202, Закарпатська обл., Україна

protopopova.vira@gmail.com; evandrik23@gmail.com

${ }^{5}$ Інститут ботаніки ім. М.Г. Холодного НАН України

вул. Терещенківська 2, Київ 01004, Україна

shevera.myroslav@gmail.com

Orlov O.O ${ }^{1}$, Iakushenko D.M. ${ }^{2}$, Májeková J. ${ }^{3}$, Zaliberová M. ${ }^{3}$, Protopopova V.V. ${ }^{4,5}$, Andrik E.J. ${ }^{4}$, Shevera M.V. ${ }^{5,4}$ 2019. Galeopsis angustifolia (Lamiaceae), a new alien species in the flora of Ukraine. Ukrainian Botanical Journal, 76(6): 542-547.

${ }^{1}$ Poliskyi Branch of the G.M. Vysotsky Ukrainian Scientific-Research Institute of Forestry and Agro-Forest Melioration of

NAS of Ukraine and State Agency of Forest Resources of Ukraine

2 Neskorenych Str., Dovzhyk village, Zhytomyr District 10004, Zhytomyr Region

${ }^{2}$ University of Zielona Góra

1 Szafrana Str., Zielona Góra 65-516, Poland

${ }^{3}$ Institute of Botany, Plant Science and Biodiversity Center, Slovak Academy of Sciences

9 Dúbravská cesta Str., Bratislava 84523, Slovak Republic

${ }^{4}$ Ferenc Rakoczi II Transcarpathian Hungarian College of Higher Education

6 Kossuth Sq., Beregove 90200, Zakarpatsky Region, Ukraine

${ }^{5}$ M.G. Kholodny Institute of Botany, NAS of Ukraine

2 Tereschenkivska Str., Kyiv 01004, Ukraine

Abstract. Data on floristic finds of Galeopsis angustifolia (Lamiaceae), a new alien species for the Ukrainian flora, are reported. Taxonomically the species is very close to G. ladanum. The main distinguishing features between these species are: morphological characteristics of generative and vegetative organs of plants, mainly shape and size of leaves, size of petals, calyx pubescence, and chemical composition. In some neighboring to Ukraine countries, the placement of G. angustifolia in the natural or alien fraction of the flora which is under discussion. In the flora of Slovakia this species is regarded as natural, in Hungary it is included in the provisional list of archeophytes, and in Poland, at least in its northern part, and in Belarus, as a kenophyte. Plants were recorded on railways in two regions of Ukraine, in 2016-2017 in Zhytomyr Polissya (Zhytomyr Region) and in 2018 in the Zakarpattia lowland (Transcarpathian Region). Taxonomic citations, morphological characteristics, geographical (primary and secondary areas), ecological and coenotic peculiarities of $G$. angustifolia are given. According to the time of its migration, ways of distribution, and degree of naturalization this species is a kenophyte, xenophyte and colonophyte in Zhytomyr Polissya and an ephemerophyte in the Zakarpattia lowland. A map of the species distribution in Ukraine is presented.

Keywords: alien species, floristic record, Galeopsis angustifolia, railways, Ukraine, Zakarpattia lowland, Zhytomyr Polissya

Submitted 14 August 2019. Published 29 December 2019

(C) 2019 O.O Orlov, D.M. Iakushenko, J. Májeková, M. Zaliberová, V.V. Protopopova, E.J. Andrik, M.V. Shevera. Published by the M.G. Kholodny Institute of Botany, NAS of Ukraine. This is an open access article under the terms of the Creative Commons Attribution License (http://creativecommons.org/licenses/by/4.0/), which permits use, distribution, and reproduction in any medium, provided the original work is properly cited 
Орлов О.О., Якушенко Д.М., Маєкова Я., Заліберова М., Протопопова В.В., Андрик Є.Й., Шевера М.В. 2019. Galeopsis angustifolia (Lamiaceae) - новий адвентивний вид у флорі України. Український ботанічний журнал, 76(6): 542-547.

Реферат. Повідомляється про знахідку Galeopsis angustifolia (Lamiaceae), нового для флори України виду адвентивних рослин. Він таксономічно близький до G. ladanum, з якого свого часу був виділений і від якого відрізняється за формою та розмірами листків і віночка, характером опушення чашечки, а також за хімічним складом. У флорі деяких країн, що межують з Україною, приналежність виду до природної або адвентивної фракцій дискусійна. Так, у флорі Словаччини він вважається природним, в Угорщині його зараховано до провізорного списку археофітів, а в Польщі, принаймні в північній іiі частині, а також у Білорусі вид розглядається як кенофіт. Рослини G. angustifolia були виявлені на коліях залізничних станцій у двох регіонах України: у 2016 і 2017 рр. в Житомирському Поліссі, а в 2018 р. - на Закарпатській низовині. Вид належить до групи кенофітів, за способом занесення - до ксенофітів, за ступенем натуралізації - до колонофітів у Житомирському Поліссі та ефемерофітів - на Закарпатській низовині. Наведені основне таксономічне цитування, коротка морфологічна характеристика рослин, відомості щодо географічного поширення (первинний та вторинний ареали) та еколого-ценотичної приуроченості виду, складена картосхема його поширення в Україні.

Ключові слова: адвентивний вид, Житомирське Полісся, Закарпатська низовина, залізниці, Україна, флористична знахідка, Galeopsis angustifolia

Під час флористичних досліджень авторами впродовж 2016-2018 pр. було зібрано Galeopsis angustifolia Ehrh. ex Hoffm. (Lamiaceae) - новий для флори України вид адвентивних рослин, відомості про який наводимо у даній роботі (рис. 1).

Уперше в Україні G. angustifolia був зібраний в 2016 та 2017 рр. у двох районах на Житомирському Поліссі: "Житомирська обл., Олевський р-н, c. Нові Білокоровичі, залізнична станція Білокоровичі, на щебенистій відсипці та між коліями, багато, 21.06.2016, О. Орлов" (KW139869), "Житомирська обл., Олевський р-н, с. Нові Білокоровичі, залізнична станція Білокоровичі, на щебенистій відсипці та між коліями, багато, 05.07.2016, О. Орлов" (KW139867), "Житомирська обл., Коростенський р-н, 2 км південніше м. Коростень, залізнична станція Чолівка, на щебені між коліями, окремими щільними групами, 26.07.2017, Д. Якушенко, О. Орлов" (KW139868). У першому із згаданих локалітетів (с. Н. Білокоровичі) описано дві ділянки за участі виду на площі $1 \times 10$ м, уздовж залізничних рейок. Перша ділянка має загальне проективне покриття 12\%, зокрема G. angustifolia 5\%, Lactuca serriola L. - 3\%, Xanthoxalis dillenii (Jacq.) Holub - 3\%, одинично траплялися: Peplis portula L., Eschscholzia californica Cham., Sonchus asper (L.) Hill, Erigeron canadensis L., Achillea millefolium L., Echium vulgare L. На другій ділянці, із загальним проективним покриттям 13\%, відмічені Sonchus oleraceus L. - 5\%, G. angustifolia - 3\%, Linaria vulgaris Mill. $-3 \%$, Cichorium intybus L. $-1 \%$, Lotus corniculatus L. - 1\%, поодиноко зростали Daucus carota L., Oenothera ammophila Focke, Sonchus asper, Setaria viridis (L.) P. Beauv., Taraxacum officinale Wigg. aggr., Tragopogon major Jacq. У другому локалітеті

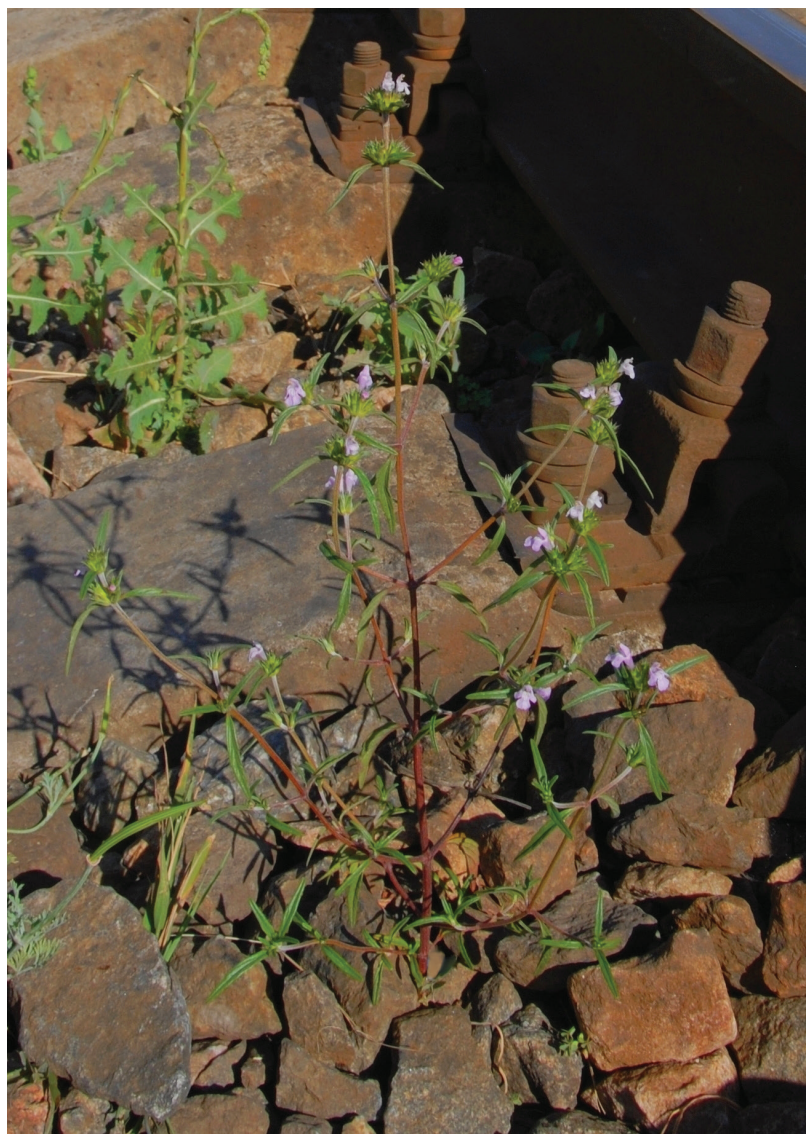

Рис. 1. Galeopsis angustifolia, загальний вигляд рослини

Fig. 1. Galeopsis angustifolia, general view

(залізнична станція Чолівка, окол. м. Коростень) особини виду зафіксовані на площі $1 \times 30$ м, уздовж залізничних колій. Загальне проективне покриття складало 10\%, зокрема $G$. angustifolia $3 \%$, Cichorium intybus - 3\%, Equisetum arvense L. $3 \%$, Eragrostis minor Host - 1\%, поодиноко відмічені 


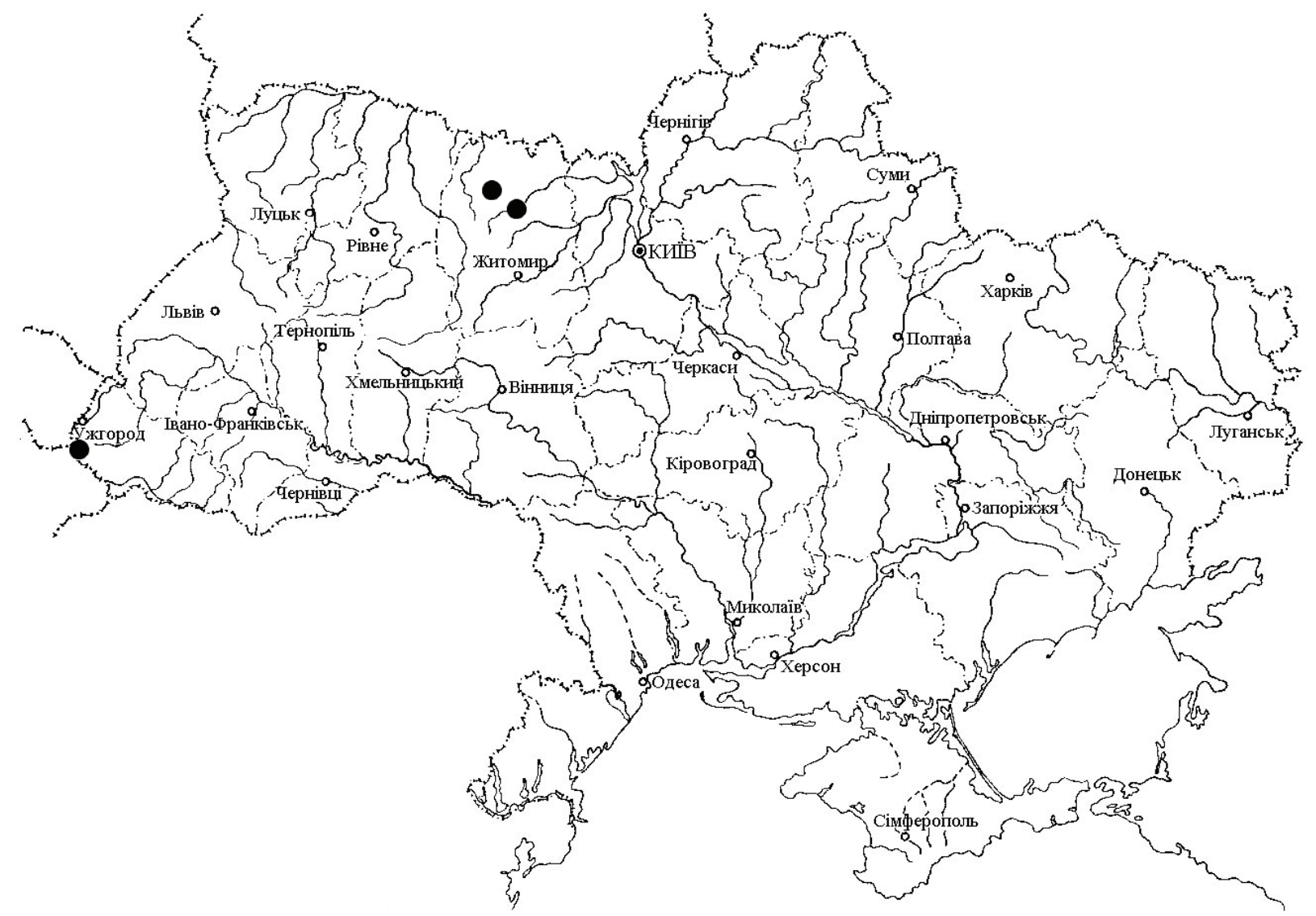

Рис. 2. Картосхема поширення Galeopsis angustifolia в Україні

Fig. 2. A schematic map of distribution of Galeopsis angustifolia in Ukraine

Ulmus pumila L. (підріст), Lotus corniculatus, Daucus carota, Oenothera rubricaulis Klebahn, Taraxacum officinale, Lactuca serriola L., Tragopogon major, Senecio viscosus L.

У 2018 p. G. angustifolia зафіксований на Закарпатській низовині, на залізниці у м. Чоп: "Ukrajna, Chop, zeleznica, 25.09. 2018, J. Májeková, M. Zaliberová" (SAV s.n.). Невелика колонія (понад десяток рослин), в якій переважали особини в стані цвітіння. Рослини відмічені у складі несформованих синантропних угруповань. Опису за участі виду в даному локалітеті не зроблено, оскільки зразки були визначені вже після їхнього збору в природі.

Сучасне поширення G. angustifolia в Україні подано на картосхемі (рис. 2).

Оскільки в українській літературі вид не вказувався, нижче наводимо його основне таксономічне цитування, морфологічний опис, дані про поширення та екологію.
Galeopsis angustifolia Ehrh. ex Hoffm., Deutschl. Fl. ed. 2, 1(2): 8 (1795). - G. ladanum L. var. angustifolia (Ehrh. ex Hoffm.) Wallr., Sched. Crit.: 302 (1822). - G. ladanum var. angustifolia (Ehrh. ex Hoffm.) Lej. \& Courtois, Comp. Fl. Belg. 2: 241 (1831), comb. superfl. - G. ladanum subsp. angustifolia (Ehrh. ex Hoffm.) Briq., Fl. Helv.: 52 (1829). - Ladanum angustifolium (Ehrh. ex Hoffm.) Slavíková, Novit. Bot. Delect. Seminum Horti Bot. Univ. Carol. Prag.: 42 (1963). - Dalanum angustifolium (Ehrh. ex Hoffm.) Dostál, Folia Mus. Rerum Nat. Bohem. Occid., Bot. 21: 11 (1984). - Ladanella angustifolia (Ehrh. ex Hoffm.) Pouzar \& Slavíková, in Čas. Nár. Muz. ser. natur. 169(1-4): 42 (2000).

Вид належить до підроду Ladanum (S.F.Gray) Rchb. роду Galeopsis L. Дуже поліморфний, розглядається різними авторами у ранзі різновиду або підвиду $G$. ladanum; відомо про перехідні форми між ними, є дані щодо гібридів за участі 
G. angustifolia (Ludwig, 1929; Gregor, Matzke-Hajek, 2006).

Від близького $G$. ladanum відрізняється морфологічними ознаками вегетативних та генеративних органів рослин, зокрема: у G. angustifolia листки звичайно лінійноланцетні до видовженоланцетних, 2-5 мм завш.; чашечка білувата, густо опушена, віночок утричі довший за неї (у G. ladanum - листки звичайно яйцеподібноланцетні, 6-16 мм завш.; чашечка зелена, гола або розсіяно опушена, віночок удвічі або менше довший за неї). Окрім того, два види також відрізняються за хімічним складом, зокрема наявністю арабінози у G. angustifolia (Tiunnikova, 2006a, b).

Galeopsis angustifolia - однорічна рослина, 10-40 см завв. Стебло прямостояче, звичайно розгалужене, вкрите залозистими червоними волосками. Листки прості, цілісні, від лінійноланцетних до видовженоланцетних, 2-5 мм завш., краї листків мають до чотирьох невеликих зубців з кожного краю. Суцвіття псевдомутовчасте. Квітки дрібні (15-25 мм завд.) 3 червонофіолетовою оцвітиною; чашечка густоволосиста, зазвичай без залоз, з видимими жилками в нижній частині, втричі коротша за віночок. Плід яйцеподібний горішок, близько 2,5 мм завд. Цвіте 3 червня до жовтня.

Поширення. Природний ареал $G$. angustifolia Західна, Центральна та Південна Європа й Марокко (https://wcsp.science.kew.org/namedetail.do?name $\mathrm{id}=85331$ ). Як рідкісний вид відомий, за винятком європейської частини Туреччини, 3 усіх країн території Балканського півострова, наприклад, у Передбалканні та причорноморській частині Болгарії (Asenov, 1989), північно-східній Греції (Dimopoulos et al., 2013), Македоніï (Teofilovsky, 2018), Сербіï (Diklić, 1974), в останній вважається більш широкопоширеним, ніж G. ladanum тощо.

За даними The Euro+Med Plantbase (World Checklist..., 2010), G. angustifolia вказується для більшості країн Європи як природний вид, для Ірландії та Швеції - як інтродуцент.

У деяких країнах вид включено в Червоні книги або Перелік рідкісних видів, наприклад: у Великій Британії зі статусом EN (VU) за категорією IUCN (Preston et al., 2004; Williamson et al., 2008) або CR - на національному рівні (Curtis, McGough, 1988; Stroh et al., 2014), у Люксембурзі - LC (Colling, 2005), y Чexiï - C3 (VU) (Grulich, 2012), у Німеччині його стан оцінений як незагрожений (Parusel, 2012).

Як кенофіт вид достовірно відомий з Ірландії, Швеції (World Checklist..., 2010), Фінляндії (Kurto et al., 2019), півдня Карелії Російської Федерації (Stankov, Taliev, 1957) та Республіки Білорусь (Tretiakov, 1998). Як археофіт він наводиться 3 території Німеччини. В Угорщині та Польщі різними авторами вид трактується неоднозначно. Tак, А. Terpó et al. (1999) включають G. angustifolia до провізорного списку археофітів Угорщини. На думку Z. Mirek et al. (2002), у Польщі G. angustifolia є природним, натомість М. Zając та A. Zając (2009) розглядають його як антропофіт у складі $G$. ladanum (Zając, Zając, 2001). Дослідник L. Rutkowski (1998) вважає його археофітом або кенофітом, тобто чужорідним, але тільки у північній частині країни, де рослини приурочені до антропогенних місцезростань. На думку E. Hultén i M. Fries (1986), тільки частина ареалу виду в межах Польщі може бути природною, з чим погоджуються E. Szczęśniak (2010), M. Jonik et al. (2010), W. Bacieczko, A. Borcz (2016). На території Словаччини G. angustifolia розглядається у складі природної фракції флори (Medvecká et al., 2012).

Екологічна приуроченість. $\mathrm{y}$ первинному ареалі рослини $G$. angustifolia трапляються на вапняках, осипах, на ескерах, прибережних пісках та галечниках, а також на орних землях, трансформованих відкритих ділянках, уздовж тротуарів тощо. У Польщі рослини приурочені до теплих мікроніш, віддають перевагу освітленим місцям, адаптовані до сухих місцезростань, багатих на карбонат кальцію та бідних на елементи живлення й органічну речовину. Останнім часом рослини виду найчастіше відмічають на антропогенних місцезростаннях, зокрема на залізницях та узбіччях автошляхів, у різних типах рослинних угруповань.

Фітоценотична приуроченість. Galeopsis angustifolia трапляється на карбонатних кам'янистих осипищах у гірських регіонах Центральної та Південної Европи. Наприклад, у Німеччині, Польщі, Чехії та Словаччині вид формує розріджені угруповання асоціації Galeopsietum angustifoliae Büker ex Bornkamm 1960 союзy Stipion calamagrostis Jenny-Lips Br.-B1. 1950 класу Thlaspietea rotundifolii Br.-B1. 1948 (Pott, 1992; Valachovič et al., 1995; Matuszkiewicz, 2007; Jarolímek et al., 2008; Chytrý, 
2009), де є діагностичним видом класу (Mucina et al., 2016).

Рослини цього виду можуть вкорінюватися в різноманітні угруповання 3 послабленою конкуренцією різних висотних поясів. Зокрема, його відмічено: на залізничних коліях і в кар'єрах у складі рудеральних угруповань союзу DaucoMelilotion Görs ex Rostański et Gutte 1971 класу Artemisietea vulgaris Lohmeyer et al. in Tx. ex von Rochow 1951, у сегетальних угрупованнях союзу Caucalidion Tx. ex von Rochow 1951 класу Papaveretea rhoeadis S. Brullo et al. 2001, а також в агломераціях із невиробленою фітоценотичною взаємодією (Prodan, Buia, 1961; Jarolímek et al., 1997; Rothmaller, 2002; Bacieczko, Borcz, 2016).

3 огляду на характер місцезростань G. angustifolia в Україні ми розглядаємо його у складі адвентивної фракції флори. Він належить за часом занесення до кенофітів, за способом занесення - до ксенофітів, за ступенем натуралізації - до колонофітів у Житомирському Поліссі та до ефемерофітів - на Закарпатській низовині. На територію Житомирської області вид потрапив, ймовірно, з Польщі або Білорусі, на Закарпаття - зі Словаччини, оскільки відомий на прикордонній залізничній Чєрна-над-Тисоу (Májeková et al., 2014, 2016; Jehlík et al., 2017) та поблизу неї на станціях Добра, Вельке Капушани, Кошице. В Україні G. angustifolia поки що відомий тільки із означених регіонів, але, можливо, він уже поширився і в інших, тому звертаємо увагу ботаніків на можливе знаходження його нових локалітетів.

Гербарні зразки виду зберігаються в Гербаріях Інституту ботаніки ім. М.Г. Холодного НАН України (KW) та Ботанічного інституту, Центра біології рослин та біорізноманіття Словацької АН (SAV).

\section{Подяки}

Автори вдячні доктору біологічних наук, с.н.с. М.М. Федорончуку (Інститут ботаніки НАН України) за консультацію при підготовці інформації щодо таксономічного цитування виду.

Робота виконана в рамках спільного українськословацького наукового проекту "Екологічні й географічні особливості та головні шляхи міграції інвазійних видів рослин прикордоння України та Словаччини" (2017-2019) у рамках Угоди про співпрацю між НАН України та Словацької АН.

\section{СПИСОК ПОСИЛАНЬ}

Asenov I. 1989. Galeopsis. In: Flora Reipublicae Popularis Bulgaricae, vol. 9. Ed. B. Kuzmanov. Sofia: Academia Scientiarium Bulgarica, Institutum Botanicum cum Horto, pp. 431-438.

Bacieczko W., Borcz A. 2016. A new locality of Galeopsis angustifolia (Ehrh.) Hoffm. in Pyrzyce plain (West Pomerania, Poland). Acta Agrobotanica, 69(1): 1651. https://doi.org/10.5586/aa.1651

Chytrý M. 2009. Vegetace České republiky. 2. Ruderální, plevelová, skalni a sutová vegetace. Praha: Academia, $520 \mathrm{pp}$.

Colling G. 2005. Red List of the Vascular plants of the Luxemburg. Luxembourg: Travaux scientifiques du Musée national d'histoire naturelle Luxembourg, $82 \mathrm{pp}$.

Curtis T.G.F., McGough H.N. 1988. The Irish Red Data Book, vol. 1. Vascular Plants. Dublin: Published by the Stationery Office, $80 \mathrm{pp}$.

Dimopoulos P., Raus Th., Bergmeier E., Constantinidis Th., Iatrou G., Kokkini S., Strid A., Tzanodacis D. 2013. Vascular flora of Greece: an annotated checklist. Englera, 31: $1-372$.

Diklić N. 1974. Galeopsis. In: Flore de la République Socialiste de Serbie, vol. 6. Ed. M. Josifović. Beograd: Académie Serbe des Sciences et des Arts, pp. 386-393.

Gregor Th., Matzke-Hajek G. 2006. Zur Benennung der Hybride aus Galeopsis angustifolia Pers. und Galeopsis segetum Neck. Kochia, 1: 143-145.

Grulich V. 2012. Red List of vascular plants of the Czech Republic, $3^{\text {rd }}$ ed. Preslia, 84: 631-645.

Hultén E., Fries M. 1986. Atlas of North European vascular plants north to the Tropic of Cancer, vols 1-3. Königstein: Koeltz Scientific Books, vol. 1, xviii +498 pp.; vol. 2, xiv + pp. 499-968; vol. 3, pp. 969-1149.

Jarolímek I., Zaliberová M., Mucina L., Mochnacký S. 1997. Rastlinné spoločenstvá Slovenska, vol. 2. Synantropná vegetácia. Bratislava: Vydavatel'stvo Slovenskej akadémie vied: Veda, $416 \mathrm{pp}$.

Jehlík V., Májeková J., Zaliberová M. 2017. The influence of the Eastern migration route on the Slovak flora - a comparison after 40 years. Tuexenia, 37: 313-332. https://doi.org/10.14471/2016.37.023

Jonik M., Nobis A., Nobis M. 2010. Rozmieszczenie i preferencje siedliskowe Galeopsis angustifolia (Ehrh.) Hoffm. i G. ladanum L. na podstawie rewizji materiałów zielnikowych - wyniki wstępne. In: LV Zjazd Polskiego Towarzystwa Botanicznego "Planta in vivo, in vitro et in silico" (Warszawa, 6-12 września 2010). Eds A. Szczepkowski, A. Obidziński. Warszawa: Streszczenia referatów i plakatów, Polskie Towarzystwo Botaniczne, s. 47.

Kurto A., Lampinen R., Piirainen M., Uotila P. 2019. Checklist of the vascular plants of Finland. Suomen putkilokasvien luettelo. Norrlinia, 34: 1-206.

Ludwig A. 1929. Galeopsis dubia Leers $\times$ angustifolia Ehrh. Sitzungsber. Naturhist. Vereins Preuss. Rheinl. 1928 D: $1-7$.

Májeková J., Letz D.R., Slezák M., Zaliberová M., Hrivnák R. 2014. Rare and threatened vascular plants 
of the railways in Slovakia. Biodiversity: Research and Conservation, 35: 75-85.

Májeková J., Jehlík V., Zaliberová M. 2016. Railway stations vs. thermophilous species (example from Eastern Slovakia). Thaiszia - Journal of Botany, Košice, 26(2): 173-188.

Matuszkiewicz W. 2007. Przewodnik do oznaczania zbiorowisk roślinnych Polski. Warszawa: Wydawnictwo naukowe PWN, $536 \mathrm{pp}$.

Mirek Z., Piękoś-Mirkowa H., Zając A., Zając M. 2002. Flowering plants and pteridophytes of Poland. A checklist. Biodiversity of Poland, vol. 1. Kraków: W. Szafer Institute of Botany, PAN, $442 \mathrm{pp}$.

Mucina L., Bültmann H., Dierßen K., Theurillat J.-P., Raus T., Čarni A., Šumberová K., Willner W., Dengler J., Gavilán R., Chytrý M., Hájek M., Di Pietro R., Iakushenko D., Pallas J., Daniels F.J.A., Bergmeier E., Santos Guerra A., Ermakov N., Valachovič M., Schaminée J.H.J., Lysenko T., Didukh Ya.P., Pignatti S., Rodwell J.S., Capelo J., Weber H.E., Solomeshch A., Dimopoulos P., Aguiar C., Hennekens S.M., Tichý L. 2016. Vegetation of Europe: hierarchical floristic classification system of vascular plant, bryophyte, lichen and algal communities. Applied Vegetation Science, 19, Suppl. 1: 3-264.

Parusel E. 2012. Czerwona lista roślin naczyniowych województwa Sląskiego. Katowice: Centrum Dziedzictwa Przyrody Górnego Sląska, 77 s.

Preston Ch.D., Pearman D.A., Hall A.R. 2004. Archaeophytes in Britain. Botanical Journal of the Linnean Society, 145(3): 257-294. https://doi.org/10.11 $11 / \mathrm{j} .1095-8339.2004 .00284$

Prodan I., Buia Al. 1962. Flora mică ilustrată a Republicii Populare Romine. Bucureşti: Editura Agro-Sylvică, $676 \mathrm{pp}$.

Pott R. 1992. Die Pflanzengesellschaften Deutschlands. Stuttgart: Verlag Eugen Ulmer, 428 S.

Rothmaler W. 2002. Exkursionsflora von Deutschland, Bd. 4. Gefässpflanzen: Kritischer Band Herausgeber E.J. Jáger, K. Werner. 10. Aufl. Berlin: Spektrum Akademischer Verlag Heilderberg, 948 S.

Stankov S.S., Taliev V.I. 1957. Galeopsis. In: Opredelitel vysshikh rasteniy evropeyskoy chasti SSSR. Moscow: Gosudarstvennoe izdatelstvo Sovetskaya nauka, pp. 529530. [Станков С.С., Талиев В.И. 1957. Galeopsis. В кн.: Определитель высших растений европейской части СССР. Москва: Государственное издательство Советская наука, с. 529-530].

Stroh P.A., Leach S.J., August T.A., Walker K.J., Pearman D.A., Rumsey F.J., Harrower C.A., Fay M.F., Martin J.P., Pankhurst T., Preston C.D., Taylor I. 2014. A Vascular Plant Red List for England. Bristol: Botanical Society of Britain and Ireland, 193 pp.
Szczęśniak E. 2010. Galeopsis angustifolia (Ehrh.) Hoffm. in South-Western Poland: origin, expansion and disappearance. In: IX International Conference Anthropization and Environment of Rural Settlements. Flora and Vegetation (Kamyanets-Podilskiy \& Boyany, Ukraine, 29 June - 01 July 2010). Program, Proceedings and Excursions. Kyiv, p. 59. http://www.botany.kiev.ua/doc/ IX_PROCEEDINGS.pdf

Teofilovsky A. 2018. Chorological data for some new, doubtfully known and rare plants in the flora of the Republic of Macedonia. Acta Musei Macedonici Scientiarum Naturalium, 21: 13-22.

Terpó A., Zając M., Zając A. 1999. Provisional list of Hungarian archeophytes. Thaiszia - Journal of Botany, Košice, 9: 41-47.

Tiunnikova N.V. 2006a. Botanicheskii Zhurnal, 91(2): 290-296. [Тюнникова Н.В. 2006а. Об объеме рода Galeopsis L. (Lamiaceae). Ботанический журнал, 91(2): 290-296].

Tiunnikova N.V. 2006b. Rod Galeopsis L. (Lamiaceae Lindl.) vo flore Rossii (sistematika, geografiya, fitokhimicheskie osobennosti: Cand. Sci. Diss. Abstract. St. Petersburg, Komarov Botanical Institute of the Russian Academy of Sciences, 19 pp. [Тюнникова Н.В. 2006b. Род Galeopsis L. (Lamiaceae Lindl.) флоры России (систематика, география, фитохимические особенности: автореф. дис. ... канд. биол. наук. Санкт-Петербург, Ботанический институт им. В.Л. Комарова РАН, 19 c.].

Tretiakov D.I. 1998. Botanicheskii Zhurnal, 83(9): 119-132. [Третьяков Д.И. 1998. Новые заносные виды растений для флоры Беларуси. Ботанический журнал, 83(9): 119-132].

Ot’ahel'ová H., Stanová V., Maglocký Š. 1995. Rastlinné spoločenstvá Slovenska, vol. 1. Pionierska vegetácia. Ed. M. Valachovič. Bratislava: Veda, 192 s.

Williamson M., Stout J.C., Dehnen-Schmutz K., Milbau A., Hall A.R. 2008. A provisional list of Irish archaeophytes. Irish Naturalists' Journal, 29(1): 30-35.

World Checklist of Selected Plant Families. 2010. Galeopsis angustifolia. In: Euro+Med (2006-): Euro+Med PlantBase - the information resource for Euro-Mediterranean plant diversity.Available at:https://ww2.bgbm.org/EuroPlusMed/ PTaxon Detail.asp? $\mathrm{NameCache}=$ Galeopsis $\% 20$ angustifolia\&PTRefFk=8000000 (Accessed 5 March 2019).

Zając M., Zając A. 2009. Elementy geograficzne rodzimej flory Polski. Kraków: Instytut Botaniki Uniwersytetu Jagiellońskiego, $94 \mathrm{~s}$.

Zając A., Zając M. 2001. Atlas rozmieszczenia roślin naczyniowych w Polsce - Distribution Atlas of Vascular Plants in Poland. Kraków: Instytut Botaniki UJ, xii + $716 \mathrm{~s}$.

Рекомендує до друку М.М. Федорончук 
https://doi.org/10.15407/ukrbotj76.06.548

\title{
Cephalaria gigantea (Caprifoliaceae) - новий адвентивний вид флори України
}

\author{
Анна А. КУЗЕМКО ${ }^{1}$, Олена Г. ЯВОРСЬКА², Анна I. КОВТОНЮК 3 \\ ${ }^{1}$ Інститут ботаніки ім. М.Г. Холодного НАН України \\ вул. Терещенківська 2, Київ 01004, Україна \\ anyameadow.ak@gmail.com \\ ${ }^{2}$ Донецький національний університет імені Василя Стуса \\ вул. 600-річчя 21, Вінниця 21021, Україна \\ zsp.yavorska@gmail.com \\ ${ }^{3}$ Національний дендрологічний парк "Софіївка" НАН України \\ вул. Київська 12а, Умань 20300, Черкаська область, Україна \\ annahloris@gmail.com
}

Kuzemko A.A. ${ }^{1}$, Yavorska O.G. ${ }^{2}$, Kovtoniuk A.I. ${ }^{3}$ 2019. Cephalaria gigantea (Caprifoliaceae), a new alien species in the flora of Ukraine. Ukrainian Botanical Journal, 76(6): 548-553.

${ }^{1}$ M.G. Kholodny Institute of Botany, National Academy of Sciences of Ukraine

2 Tereshchenkivska Str., Kyiv 01004, Ukraine

${ }^{2}$ Vasyl Stus Donetsk National University, Ukraine

21 600-richya Str., Vinnytsia 21021, Ukraine

${ }^{3}$ Sofiyivka National Dendrological Park, National Academy of Sciences of Ukraine, Uman, Ukraine

12a Kyivska Str., Uman 20300, Cherkasy Region, Ukraine

Abstract. Information about a locality of Cephalaria gigantea, a new for Ukraine alien species, is provided. It was found in the Podillya Botanical Garden, Vinnytsia city, in July 2016 during surveys of the spontaneous flora and vegetation of the garden and park landscapes of the Middle Pobuzhzhia area. The territory of the garden is currently rather neglected. We assume that the plant material for introduction of $C$. gigantea was probably collected during an expedition of the botanical garden staff to the Caucasus in the 1970's. The introduced species was cultivated in the collection of medicinal plants, which was abandoned in the late 1980s. The population of $C$. gigantea was found at a distance of more than $300 \mathrm{~m}$ from the former collection site at the forest edge, in the part of the botanical garden distant from the main recreational paths. Taking into account that this species is mentioned as alien for several countries of Europe, monitoring of its further dispersal in Ukraine, particularly of its cultivation sites, is recommended.

Keywords: alien species, Cephalaria gigantea, ergasiophyte, floristic record, naturalization, Ukraine

Submitted 20 September 2017. Published 29 December 2019

Куземко А.А., Яворська О.Г., Ковтонюк А.І. 2019. Cephalaria gigantea (Caprifoliaceae) - новий адвентивний вид флори України. Український ботанічний журнал, 76(6): 548-553.

Реферат. Наведено інформацію про знахідку нового для флори України виду адвентивних рослин - Cерhalaria gigantea. Вид виявлений в ботанічному саду "Поділля" (м. Вінниця) у липні 2016 року під час дослідження спонтанної флори та рослинності садово-паркових ландшафтів Середнього Побужжя. Цей ботанічний сад на сьогодні знаходиться в занедбаному стані. Автори роблять припущення, що інтродукційний матеріал $C$. gigantea було зібрано під час експедиції співробітників ботсаду на Кавказ у 1970-х рр. і вид з того часу вирощувався на колекційній ділянці лікарських рослин (колекцію було втрачено наприкінці 1980-х рр.). Популяцію виду було виявлено на відстані понад 300 м від колишньої колекційної ділянки на узліссі лісового масиву у частині ботанічного саду, віддаленій від основних рекреаційних потоків. Враховуючи, що даний вид наводиться як адвентивний щонайменше ще для десяти країн Європи, він потребує моніторингу його подальшого поширення на території України; особливої уваги потребують місця його культивування.

Ключові слова: адвентивний вид, ергазіофіт, натуралізація, Україна, флористична знахідка, Cephalaria gigantea

(C) 2019 A.A. Kuzemko, O.G. Yavorska, A.I. Kovtoniuk. Published by the M.G. Kholodny Institute of Botany, NAS of Ukraine. This is an open access article under the terms of the Creative Commons Attribution License (http://creativecommons.org/licenses/by/4.0/), which permits use, distribution, and reproduction in any medium, provided the original work is properly cited 
В сучасному світі проблема неконтрольованого поширення неаборигенних організмів $є$ однією 3 глобальних загроз біорізноманіттю. Ергазіофіти види, свідомо інтродуковані до певного регіону 3 метою культивування, відіграють суттєву роль у процесі синантропізації флори і можуть спричиняти фітоінвазії (McNeely et al., 2001; Protopopova, Shevera, 2014). Осередками розповсюдження таких видів часто виступають центри інтродукції рослин - ботанічні сади та дендропарки. Саме тому, їхні співробітники мають усвідомлювати свою відповідальність i, по можливості, дотримуватися в роботі вимог "Кодексу поведінки для ботанічних садів і дендропарків" (Burda et al., 2014). Проте, інтродукційні центри часом занепадають і зникають 3 різних причин. У такому випадку рослини, які за умов відповідного догляду не проявляють інвазійної спроможності, без належного догляду можуть почати спонтанно поширюватись із різними наслідками для оточуючих природних чи напівприродних екосистем. Саме така ситуація трапилася із ботанічним садом "Поділля", який знаходиться на території м. Вінниця. За архівними матеріалами 3 фондів Вінницького краєзнавчого музею, він був заснований у 1965 р. з ініціативи Вінницького державного педінституту та Вінницької обласної організації Українського товариства охорони природи. Офіційно сад було відкрито в 1967 р. Проте, до цього часу, на жаль, він не має офіційного статусу ботанічного саду, хоча є об'єктом природно-заповідного фонду. Так, з 27 липня 1977 р. він отримав статус парку-пам'ятки садово-паркового мистецтва загальнодержавного значення. Науковими керівниками проекту Ботанічного саду "Поділля" були доктор біологічних наук, професор А.М. Паламарчук та кандидат сільськогосподарських наук, доцент Г.Л. Паламарчук. Незмінним директором ботанічного саду з часу заснування і впродовж близько 25 років був I.C. Глазков, у цей же період відділ помології та лікарських рослин очолював М. Максименюк. Саме ці ентузіасти організовували експедиції на Далекий Схід, Алтай і Кавказ для створення та поповнення колекцій рослин. На момент передання "Поділля" у відання Вінницького державного аграрного університету (тепер Вінницький національний аграрний університет) 25 грудня 1993 р. колекцію трав'яних рослин було повністю втрачено.
Улітку 2016 р. під час досліджень спонтанного рослинного покриву садово-паркових ландшафтів Середнього Побужжя на території ботанічного саду "Поділля" нами було виявлено популяцію $\left(49^{\circ} 12^{\prime} 40.921^{\prime \prime} \mathrm{N}, 28^{\circ} 24^{\prime} 58.869^{\prime \prime}\right.$ Е) нової для флори України рослини - Cephalaria gigantea (Ledeb.) Bobrov.

Cephalaria gigantea (Ledeb.) Bobrov, Bot. Zhurn. S.S.S.R. 17: 490 (1932).

(= Cephalaria elata Schrad. ex Roem. \& Schult.; C. tatarica Schrad ex Roem. \& Schult.; C. caucasica Litv.; Scabiosa gigantea Ledeb.; S. elata Hornem.; S. tatarica M.Bieb., nom. illeg., non L.; Cerionanthus tataricus Schott ex Roem. \& Schult., etc.). Головачка гігантська.

Багаторічна трав'яна рослина $1-2(3,5)$ м завв. Пагони прямостоячі. Стебла щільні, жорсткі, гіллясті, у верхній частині слабкоi коротковолосисті. Листкорозміщення в прикореневій розетці, по довжині стебла супротивне. Листки темно-зелені, волосисті, ліроподібні, пірчасторозсічені, їхні сегменти у кількості 2-6 пар, загострені на верхівці, зубчасті, майже низхідні, кінцевий сегмент найбільший за розміром. Суцвіття - куляста голівка 4-6 см у діаметрі. Листочки загальної обгортки чорнуваті цілком, або тільки на верхівці, яйцеподібнотрикутні; приквіткові луски чорнуваті на верхівці, рідко війчасті по краю, довгасті, загострені; усі опушені та з довгими щетинками. Квітки неправильні, сірчано-жовті, блідо-жовті або кольору слонової кістки, віночок 4-лопатевий, $0,7(1,0)$ см завд., у крайових квіток різко збільшений до 2,0-2,5(5) см. Тичинки в кількості 4 штук. "Зовнішня чашечка" має 8 зубців $1(1,5)$ мм завд. Плід - сім'янка бурого чи зеленого кольору, до 7 мм завд., волосиста, чотиригранна.

Світлолюбна, середньовибаглива до зволоження та поживності грунту рослина. Є.Г. Бобров (Bobrov, 1932, 1957) зазначав, що на Кавказі вид розповсюджений від невисоких передгір'їв до альпійських луків, і має значну вертикальну та екологічну амплітуду. Загалом, у первинному ареалі, який включає Туреччину (Середнє, Східне Причорномор'я та північно-східна Анатолія) та Кавказ, рослини цього виду ростуть по берегах водотоків, на вологих луках, скелястих схилах, вирубках, лісових галявинах та узліссях на висоті 


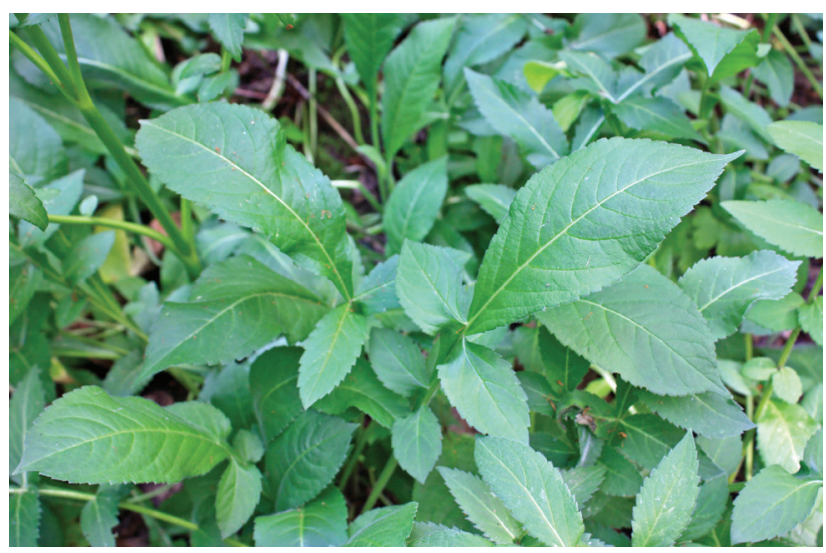

A

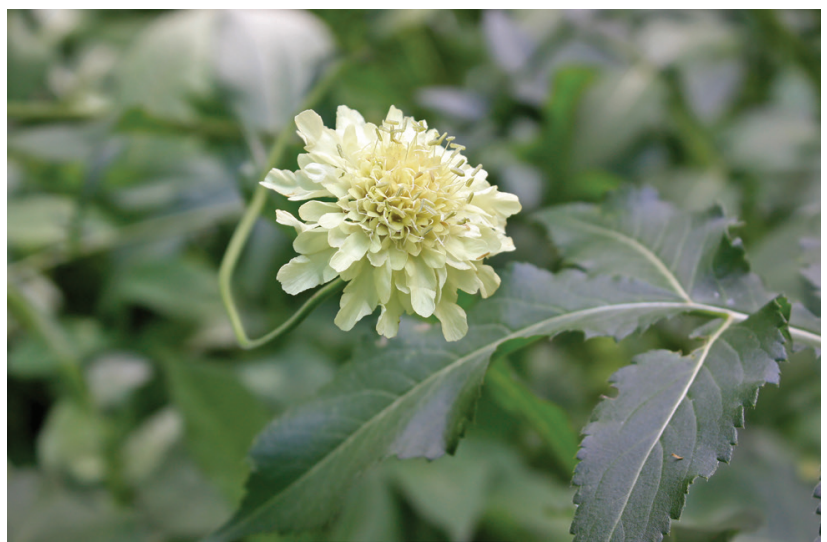

C

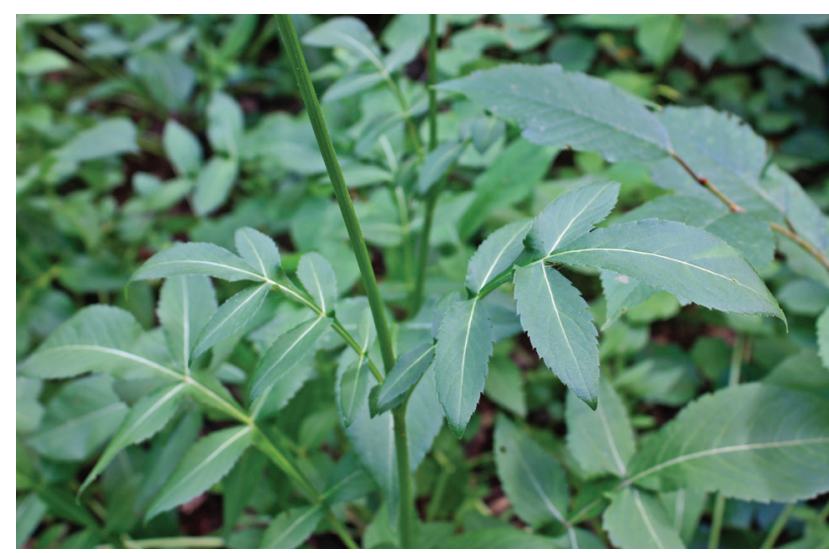

B

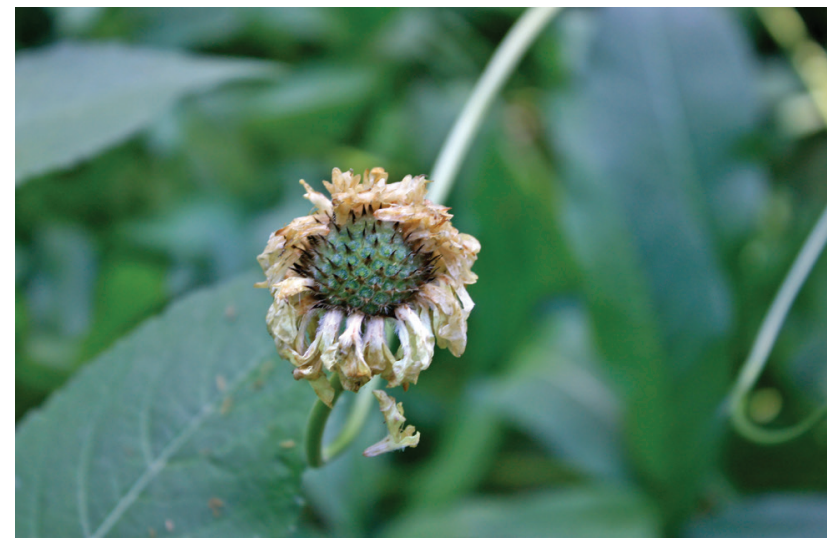

D

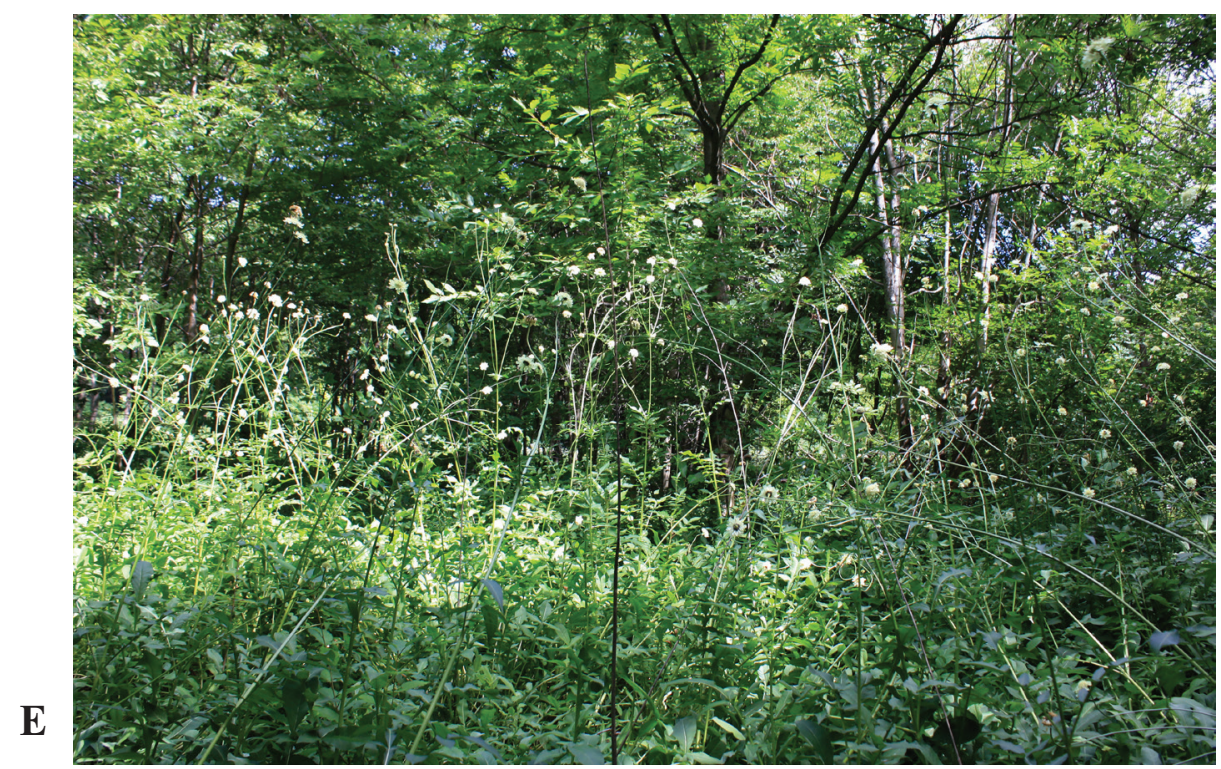

Рис. 1. Cephalaria gigantea (Ledeb.) Bobrov на околиці ботанічного саду "Поділля", м. Вінниця. А: нижні листки; В: стеблові листки; C: суцвіття; D: супліддя; E: загальний вигляд популяції

Fig. 1. Cephalaria gigantea (Ledeb.) Bobrov in the outskirts of the Podillya Botanical Garden, Vinnytsia city. A: lower leaves; B: cauline leaves; C: inflorescence; D: infructescence; E: general view 
до 3000 м н.р.м. (Güneş, Özhatay, 2011; Göktürk, Sümbül, 2014).

Від більшості видів роду Cephalaria флори України C. gigantea відрізняється, насамперед, великим розміром, хоча він, як зазначає Є.Г. Бобров (Bobrov, 1957), може суттєво варіювати, що пов'язано зі згаданою вище широкою екологічною амплітудою виду. Зокрема, за його даними, на Кавказі висота рослин становить 1,0-1,5 м. У природному ареалі в Туреччині висота стебел може сягати 3,5 м (Göktürk, Sümbül, 2014). Виявлені нами особини мали стебла до 2,5 м завв. Великими розмірами характеризується також інший вид цього роду $-C$. litvinovii Bobrov, який в окремих джерелах (Maevskiy, 2014) включають до синонімів C. gigantea. Однак від цього ендемічного виду, що поширений лише в басейні Дону і внесений до Червоної книги України (Ostapko..., 2009), C. gigantea відрізняється низкою особливостей. Так, вид має стебло з розсіяним або щільним довгим опушенням у нижній частині та коротким опушенням у верхній, натомість C. litvinovii довгого опушення в нижній частині стебла не має. Крім того, листочки обгортки у $C$. gigantea притиснутоопушені і довгощетинисті, а у C. litvinovii позбавлені довгих щетинок. Приквіткові луски у C. litvinovii по краю з густими довгими війками, а у C. gigantea - з рідкими короткими (Bobrov, 1932, 1957). Крім того, виявлені нами рослини мали нижні листки переважно із двома бічними сегментами (рис. $1, \mathrm{~A})$, а як зазначає Є.Г. Бобров (Bobrov, 1957), для нижніх листків цього виду характерні 2-6 пар бічних сегментів, а для C. litvinovii - 4-6 пар. Стеблові листки були менших за нижні розмірів, із 3-4 парами сегментів (рис. 1, В); суцвіття мали діаметр близько 6 см із крайовими квітками до 2,5 см завд. (рис. 1, С), що також цілком відповідає морфологічному опису рослин C. gigantea (Bobrov, 1957; Göktürk, Sümbül, 2014).

У первинному ареалі $C$. gigantea цвіте впродовж червня-серпня, плодоносить у липні-вересні. Ми виявили цю рослину 10 липня 2016 р., коли відбувалося iï масове цвітіння, а окремі особини починали формувати плоди (рис. 1, D).

Виявлена нами популяція нараховувала близько 80 генеративних особин і займала площу близько $30 \mathrm{~m}^{2}$ на узліссі лісового масиву з домінуванням Fraxinus excelsior L. (рис. 1, Е). Ділянка досить добре зволожена, достатньо освітлена, хоча i дешо притінена оточуючими деревами та кущами.
Ми припускаємо, що цей вид міг поширитися 3 колишньої колекційної ділянки лікарських рослин, яка нині є лучно-степовою галявиною, оскільки популяцію $C$. gigantea було виявлено нами на відстані понад 300 м від неї. Однак те, що рослини ростуть від ймовірної ділянки первинної інтродукції на досить значній відстані й популяція шляхом самопідтримання існує щонайменш 30 років, дозволяє говорити про входження $C$. gigantea до складу спонтанної флори як адвентивного виду - колонофіта; на прилеглих до ботанічного саду територіях цього виду поки що виявлено не було. До складу колекції лікарських рослин цей вид, ймовірно, потрапив зі свого природного ареалу на Кавказі, куди співробітники ботсаду здійснили експедицію в 1970-х рр.

Тип біотопу, на якому відмічено популяцію виду, за своїми екологічними характеристиками досить подібний до біотопів, до яких він приурочений у природному ареалі. Це відкрита ділянка на узліссі, але віддалена від основних потоків рекреантів, що перешкоджає прямому антропогенному впливу на популяцію.

За літературними даними цей вид наводиться як адвентивний для Норвегії (Gederaas et al., 2012), Словаччини (Medvecká et al., 2012), Чеської Республіки (Рyšek et al., 2012), Російської Федерації (Mayorov, Vinogradova, 2013), Австрії (Wallnöfer et al., 2015). Також у базах даних Invasive Species Compendium (CABI, 2019) i DAISIE (DAISIE, 2019) вказується для Великої Британії, Данії, Люксембургу, Фінляндії, Швеції, а в інформаційній системі Euro+Med PlantBase (Domina, 2017) також і для Італії. Cephalaria gigantea культивується як декоративна, лікарська та технічна культура. Рослина є отруйною (Güneş, Özhatay, 2011).

За інформацією, наведеною в "Каталозі декоративних трав'янистих рослин ботанічних садів і дендропарків України" (Kataloh..., 2015) в Україні C. gigantea вирощується в Національному ботанічному саду ім. М.М. Гришка НАН України, НДЛ "Ботанічний сад" Навчальнонаукового центру "Інститут біології" Київського національного університету імені Тараса Шевченка та ботанічному саду Львівського національного університету імені Івана Франка. За усним повідомленням Н.М. Сичак, у Львові також спостерігається спонтанне поширення цього виду за межі колекційної ділянки. Цей вид також, ймовірно, культивувався в 
Царициному саду в м. Умань (нині Національний дендрологічний парк "Софіївка" НАН України) ще в 19 сторіччі, оскільки він як C. tatarica Gmel. наводиться для Умані I. Шмальгаузеном: "Умань (Рог.)" (Schmalhausen, 1886: 267), скоріш за все за гербарним зразком П. Роговича: "Киевская губ., около Умани, в царском саду 6 июля 1844" (KW). Саме цей зразок є першим документальним підтвердженням зростання виду на території України. Не виключено, що й тоді спостерігалося спонтанне поширення рослин за межі території культивування. Однак у більш пізніх роботах щодо спонтанної флори регіону, як і загалом у зведеннях з флори України, цей вид не згадується.

Виявлена популяція потребує моніторингу щодо можливості подальшого поширення рослин. Крім того, враховуючи здатність даного виду до спонтанної натуралізації, необхідні спостереження за його поширенням в інших інтродукційних центрах, де цей вид культивується. Охарактеризована знахідка свідчить про необхідність детального флористичного обстеження колишніхінтродукційнихцентрів, якізникли 3 тих чи інших причин, або не мають належного догляду і тому знаходяться в занедбаному стані, оскільки такі об'єкти можуть бути потенційними джерелами поширення адвентивних видів.

Зібрані гербарні зразки передано до гербаріїв Національного дендрологічного парку "Софіївка" НАН України (SOF) та Інституту ботаніки ім. М.Г. Холодного НАН України (KW).

\section{СПИСОК ПОСИЛАНЬ}

Bobrov E.H. 1932. Botanicheskiy zhurnal SSSR, 17(5-6): 483-505. [Бобров Е.Г. 1932. К познанию рода Cephalaria Schrad. Многолетние виды СССР. Ботанический журнал СССР, 17(5-6): 483-505.

Bobrov E.H. 1957. Dipsacaceae. In: Flora SSSR (Flora URSS). Eds B.K. Shyshkin, Y.G. Bobrov. Moscow; Leningrad: Izdatelstvo Akademii Nauk SSSR, vol. 24, pp. 13-93. [Бобров Е.Г. 1957. Dipsacaceae. В кн.: Флоpa СССР. Ред. Б.К. Шишкин, Е.Г. Бобров. Москва; Ленинград: Издательство Академии наук СССР, т. 24, c. 13-93].

Burda R.I., Prykhodko S.A., Kuzemko A.A., Bagrykova N.O. 2014. Kodeks povedinky botanichnykh sadiv ta dendroparkiv Ukrainy shchodo invaziynykh chuzhoridnykh vydiv. Kyiv; Donetsk, 20 pp. [Бурда P.I., Приходько С.А., Куземко А.А., Багрикова Н.О. 2014. Кодекс поведінки ботанічних садів та дендропарків України щодо інвазійних чужорідних видів. Київ; Донецьк, 20 с.].
CABI. 2019. Cephalaria gigantean. In: Invasive Species Compendium. Wallingford, UK: CAB International. Available at: https://www.cabi.org/isc/datasheet/113099 (accessed 22 March 2019).

Domina G. 2017. Dipsacaceae. In: Euro+Med (2006-): Euro + Med PlantBase - the information resource for EuroMediterranean plant diversity. Available at: http://ww2. bgbm.org/EuroPlusMed/PTaxonDetailOccurrence.as p? NameId $=19362 \&$ PTRefFk $=7500000 \quad$ (Accessed 22 March 2019).

DAISIE. 2019. Cephalaria giganteum. In: European Invasive Alien Species Gateway. Available at: http://www.europealiens.org/speciesFactsheet.do? speciesId=24273\# (Accessed 22 March 2019).

Gederaas L., Moen T.L., Skjelseth S., Larsen L.K. 2012. Alien species in Norway - with the Norwegian Black List. Trondheim: The Norwegian Biodiversity Information Centre, 214 pp.

Göktürk R.S., Sümbül H. 2014. A taxonomic revision of the genus Cephalaria (Caprifoliaceae) in Turkey. Turkish Journal of Botany, 38(5): 927-968. https://doi. org/10.3906/bot-1310-6

Güneş F., Özhatay N. 2011. An ethnobotanical study from Kars (Eastern) Turkey. Biological Diversity and Conservation, 4: 30-41.

Kataloh dekoratyvnykh trav'yanystykh roslyn botanichnykh sadiv $i$ dendroparkiv Ukrainy: Dovidnykovyi posibnyk. 2015. Ed. S.P. Mashkovska. Kyiv, 282 pp. (e-edition). Available at: http://www.nbg.kiev.ua/upload/biblio/ katalog.pdf. [Каталог декоративних трав'янистих рослин ботанічних садів і дендропарків Украӥни: Довідниковий посібник. 2015. Під ред. С.П. Машковської. Київ, 282 с. (електронне видання)].

Maevskiy P.F. 2014. Flora sredney polosy evropeyskoy chasti Rossii. $11^{\text {th }}$ ed. Moscow: KMK Scientific Press, $635 \mathrm{pp}$. [Маевский П.Ф. 2014. Флора средней полосы европейской части России. 11-е изд. Москва: Товарищество научных изданий KMK, 635 с.].

Mayorov S.R., Vinogradova Yu.K. 2013. Vestnik Udmurtskogo universiteta, 2: 12-16. [Майоров С.Р., Виноградова Ю.К. 2013. Натурализация растений в ботанических садах г. Москвы. Вестник Удмуртсккого универcumema, 2: 12-16].

McNeely J.A., Mooney H.A., Neville L.E., Schei P.J., Waage J.K. 2001. Global Strategy on Invasive Alien Species. Gland, Switzerland: IUCN, $50 \mathrm{pp}$.

Medvecká J., Kliment J., Májeková J., Halada L., Zaliberová M., Gojdičová E., Feráková V., Jarolímek I. 2012. Inventory of the alien flora of Slovakia. Preslia, 84: $257-309$.

Ostapko V.M. 2009. Cephalaria litvinovii. In: Chervona knyha Ukrainy. Roslynnyi svit (Red Data Book of Ukraine. Plant Kingdom). Ed. Ya.P. Didukh. Kyiv: Globalconsulting, 420 pp. [Остапко В.М. 2009. В кн.: Червона книга Украйни. Рослинний світ. Ред. Я.П. Дідух. Київ: Глобалконсалтинг, 420 с.].

Protopopova V.V., Shevera M.V. 2014. Ergasiophytes of the Ukrainian Flora. Biodiversity Research and Conservation, 35: 31-46. https://doi.org/10.2478/biorc-2014-0018 
Pyšek P., Danihelka J., Sádlo J., Chrtek J.Jr., Chytrý M., Jarošík V., Kaplan Z., Krahulec F., Moravcová L., Pergl J., Štajerová K., Tichý L. 2012. Catalogue of alien plants of the Czech Republic ( $2^{\text {nd }}$ edition): checklist update, taxonomic diversity and invasion patterns. Preslia, 84: 155-255.

Reveal J.L. 2012. An outline of a classification scheme for extant flowering plant. Phytoneuron, 2012-37: 1-221.

Schmalhausen I.F. 1886. Flora of South-Western Russia, or Governorates of Kiev, Volhynia, Podolia, Poltava, Chernigov, and adjacent territories. Kiev: O.V. Kulzhenko
Publ., xlviii + 783 pp. [Шмальгаузен И.Ф. 1886. Флора Юго-Западной России, т.е. губерний: Киевской, Волынской, Подольской, Полтавской, Черниговской и смежных местностей. Киев: О.В. Кульженко, xlviii + 783 pp.].

Wallnöfer B., Strudl M., Pokorny M. 2015. Über fremdländische Arten von Cephalaria (Dipsacaceae), Gilia (Polemoniaceae), Ornithopus (Fabaceae) und Trachystemon (Boraginaceae) in Osterreich. Stapfia, 103: 151-159.

Рекомендує до друку Г.В. Бойко 


\title{
New records of diatoms for the algal flora of Ukraine from water bodies of Nyzhniosulsky National Nature Park
}

\author{
Olha M. KRYVOSHEIA ${ }^{1}$, Dmytro O. KAPUSTIN ${ }^{2}$ \\ ${ }^{1}$ M.G. Kholodny Institute of Botany, NAS of Ukraine \\ 2 Tereschenkivska Str., Kyiv 01004, Ukraine \\ olha_krivosheia@ukr.net \\ ${ }^{2}$ Papanin Institute for Biology of Inland Waters RAS \\ Settle of Borok, Yaroslavl Region 152742, Russia \\ dima_kapustin@outlook.com
}

Kryvosheia O.M., Kapustin D.O.2019. New records of diatoms for the algal flora of Ukraine from water bodies of Nyzhniosulsky National Nature Park. Ukrainian Botanical Journal, 76(6): 554-559.

Abstract. Here we present new records of diatoms for the algal flora of Ukraine from water bodies of Nyzhnosulsky National Nature Park. The following species are recorded for the first time in Ukraine: Achnanthidium eutrophilum, Caloneis biconstrictoides, Encyonema lacustre, Gomphonema angusticephalum, Karayevia kolbei, K. suchlandtii, Placoneis abiskoensis, P. paraelginensis, Stauroneis balatonis, and Tryblionella salinarum. Some of them are rare and noteworthy taxa. For Caloneis biconstrictoides, it is the third known record in the world; Placoneis abiskoensis is a rare Holarctic species. The reported records of the new, rare and interesting taxa in the investigated water bodies may indicate a high nature conservation significance of Nyzhniosulsky National Nature Park as an algal reserve. The taxonomic position, synonymy, morphological features, information about ecology, distribution and original photomicrographs are provided.

Keywords: diatoms, new floristic records, Nyzhniosulsky National Nature Park, Poltava Plain Algofloristic District

Submitted 21 November 2018. Published 29 Desember 2019

Кривошея О.М. ${ }^{1}$, Капустін Д.О. ${ }^{2}$ 2019. Нові знахідки діатомових водоростей для альгофлори України з водойм Національного природного парку "Нижньосульський". Украӥнський ботанічний жсрнал, 76(6): 554-559.

${ }^{1}$ Інститут ботаніки ім. М.Г. Холодного НАН України

вул. Терещенківська 2, Київ 01004, Україна

${ }^{2}$ Інститут біології внутрішніх вод ім. І.Д. Папаніна РАН

сел. Борок, Ярославська обл. 152742, Росія

Реферат. У статті представлені дані щодо нових та цікавих видів діатомових водоростей флори України з водойм Національного природного парку "Нижньосульський". Види Achnanthidium eutrophilum, Caloneis biconstrictoides, Encyonema lacustre, Gomphonema angusticephalum, Karayevia kolbei, K. suchlandtii, Placoneis abiskoensis, P. paraelginensis, Stauroneis balatonis, Tryblionella salinarum є новими знахідками для флори України. Серед них є рідкісні та цікаві таксони. Для Caloneis biconstrictoides це третє місцезнаходження у світі, Placoneis abiskoensis є рідкісним голарктичним видом. Наявність нових, рідкісних та цікавих таксонів у досліджених водоймах засвідчує високе значення Національного природного парку "Нижньосульський" як альгорезервату зазначених видів. У статті наведено відомості про систематичне положення, синоніми, морфологічні характеристики, екологію і поширення виявлених видів та їхні оригінальні мікрофотографії.

Ключові слова: діатомові водорості, нові види, Нижньосульський національний природний парк, Полтавськорівнинний альгофлористичний район

\section{Introduction}

Although diatoms in Ukraine have been studied for more than 150 years, considerable territories of Ukraine remain poorly investigated until now. This is the case especially for the Left-Bank Forest-Steppe of Ukraine where, according to the literature data, only 350 species of diatoms have been reported (Algae of
Ukraine..., 2009). In particular, one of the interesting areas in this respect is Nyzhniosulsky National Nature Park (NSNNP), located in the lower reaches of the Sula River in Poltava and Cherkasy regions. According to the algofloristic zoning of Ukraine, this territory belongs to the Poltava Plain Algofloristic District (PalamarMordvintseva, Tsarenko, 2015). A complex of various

(C) 2019 O.M. Kryvosheia, D.O. Kapustin. Published by the M.G. Kholodny Institute of Botany, NAS of Ukraine. This is an open access article under the terms of the Creative Commons Attribution License (http://creativecommons.org/licenses/by/4.0/), which permits use, distribution, and reproduction in any medium, provided the original work is properly cited 
types of water bodies with different hydrological and hydrochemical parameters are presented in NSNNP (Nyzhniosulsky..., 2018). However, until now, data on the algal flora of the park were limited and did not represent the actual diversity of the diatom flora of this territory (Kryvosheia, Kapustin, 2019).

During the study of diatoms of NSNNP we revealed 284 species (285 infraspecies taxa, incl. typical ones) (Kryvosheia, Kapustin, 2019), including a number of new and interesting species for the flora of Ukraine which are presented in this article.

\section{Materials and methods}

Periphyton, plankton and benthos samples (38) from various types of water bodies of Nyzhniosulsky National

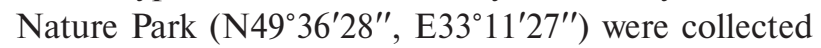
during different seasons in 2016-2017. Samples were fixed by $4 \%$ formaldehyde for later storage in the National Herbarium of Ukraine (KW-A). For diatom research, the samples were treated according to a standard technique using concentrated $35 \% \mathrm{H}_{2} \mathrm{O}_{2}$ (Prygiel, Coste, 2000). The obtained frustules were mounted in Naphrax ${ }^{\circledR}$ (refractive index 1.74) (Fleming, Roy, 1943). In addition, this material was used for scanning electron microscopy (SEM). Permanent slides were studied using light microscopes MBI- 6 with phase contrast (LOMO, Russia), Olympus BX-53 (Olympus, Japan) and a scanning electron microscope JEM-1230 (JEOL, Japan) at the Center for the Collective Use of Electron Microscopes NASU.

Diatoms were identified using issues of Süßwasserflora von Mitteleuropa (Krammer, 1986, 1991; Krammer, Lange-Bertalot, 1989), other taxonomic treatments (Krammer, 1997; Reichardt, 1999; LangeBertalot et al., 2011, 2017; Bąk et al., 2012; Bey, Ector, 2013a-d; Kulikovskiy et al., 2016), articles and electronic sources (Cox, 2003; Levkov et al., 2007; Levkov, Williams, 2014; Kulikovskiy et al., 2015, 2016; Diatoms of North America..., 2018).

In the article we followed the system of Medlin and Kaczmarska (2004) accepted in the series Algae of Ukraine...(2009), with some updates (Kulikovskiy et al., 2016).

\section{Results and discussion}

Ten species are newly reported for Ukraine. Their taxonomic position, synonymy, morphological features, information about ecology, distribution and original photomicrographs are given below.

\section{Class Bacillariophyceae}

Subclass Bacillariophycidae

Order Cymbellales D.G.Mann

Family Cymbellaceae Greville

Encyonema lacustre (C.Agardh) Pantocsek (Fig. 1, A) $(=$ Schizonema lacustre C.Agardh, Colletonema lacustre (C.Agardh) Kütz., Cymbella lacustris (C.Agardh) Cleve, Navicula lacustris (C.Agardh) Schütt).

Valves semi-lanceolate and dorsiventral. Valve apices broadly rounded. Valve length $54.04 \mu \mathrm{m}$, valve width $12.49 \mu \mathrm{m}, \mathrm{L} / \mathrm{W}$ 4.3. Axial area narrow, central area small, circular. Proximal raphe ends curve slightly to the dorsal margin. Striae radiate at the valve center and become parallel, or even convergent, near the valve apices, 11 in $10 \mu \mathrm{m}$.

Ecology. This species occurs in calcium-rich, oligo- to eutrophic water bodies with elevated levels of electrolytes, $\beta$ - $\alpha$-mesosaprobe (Lange-Bertalot et al., 2011).

Locality. Benthos, the Orzhytsia River, urban-type settlement of Orzhytsia, Orzhytsia District, Poltava Region, NSNNP, August, 2016 ( $t 26^{\circ} \mathrm{C}, \mathrm{pH}$ 8.6).

Distribution. Widely distributed in Europe, North and South America, Asia (AlgaeBase..., 2019).

Placoneis abiskoensis (Hust.) Lange-Bert. \& Metzeltin (Fig. 1, D)

(= Navicula abiskoensis Hust., $N$. dicephala f. abiskoensis (Hust.) A.Cleve, N. dicephala f. abiskoensis (Hust.) Hust.)

Valves linear, with weakly concave margins. Valve margins triundulate in the largest specimens. Apices sub-capitate. Valve length $43.85-47.76 \mu \mathrm{m}$, valve width $10.42-10.77 \mu \mathrm{m}$. Axial area very narrow and widens slightly as it approaches a transversely rectangular central area. Striae strongly curved and radiate except at the ends, where they straight and parallel, 9-10 in $10 \mu \mathrm{m}$.

Ecology. This species seems to be a northern one, in oligotrophic to mesotrophic lakes (Cox, 2003).

Locality. Plankton, the Sula River, Tarasivka village, Orzhytsia District, Poltava Region, NSNNP, August, $2016\left(t 24^{\circ} \mathrm{C}, \mathrm{pH} 8.6\right)$ and May, $2017\left(t 15^{\circ} \mathrm{C}, \mathrm{pH} 8.3\right)$.

Distribution. Rare Holarctic species (Kulikovskiy et al., 2016).

Note. According to E. Cox (2003), valves of this species have a length of $36-46 \mu \mathrm{m}$, while we found specimens with longer valves. 

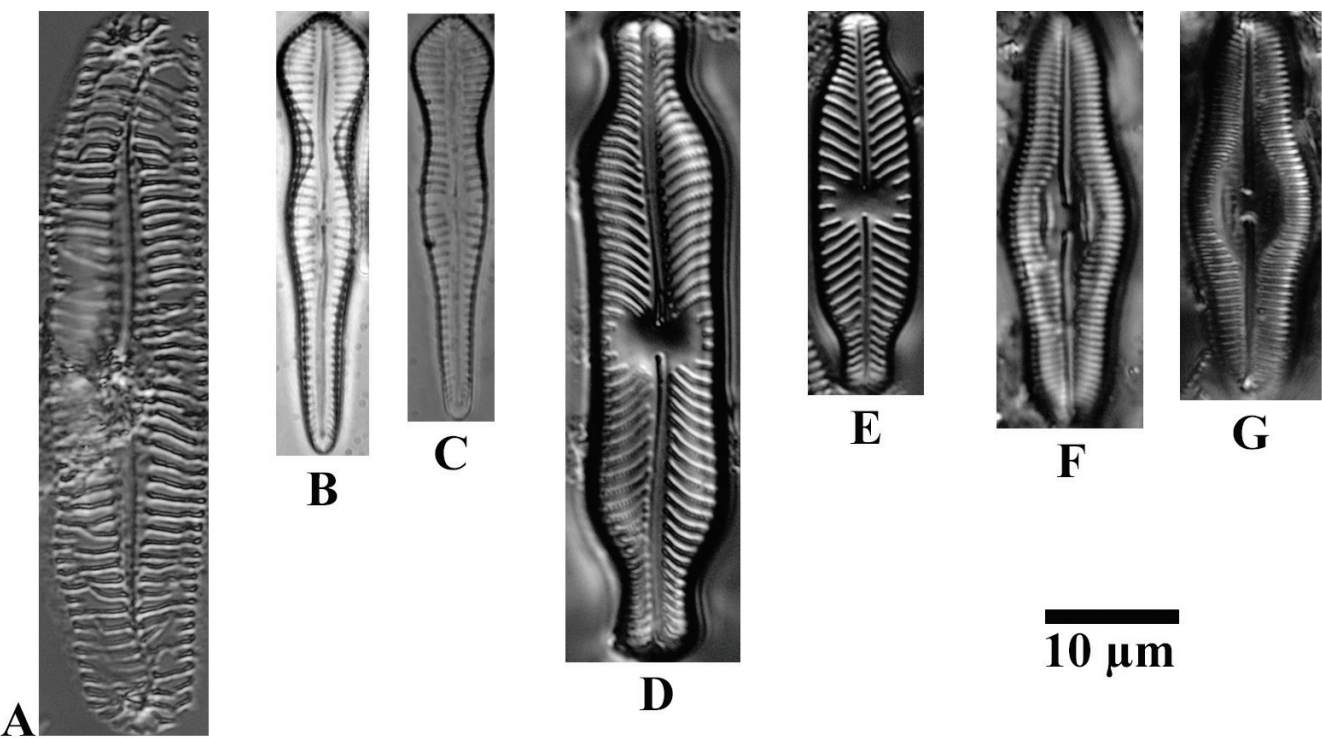

G
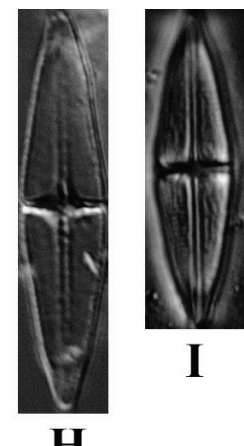

A
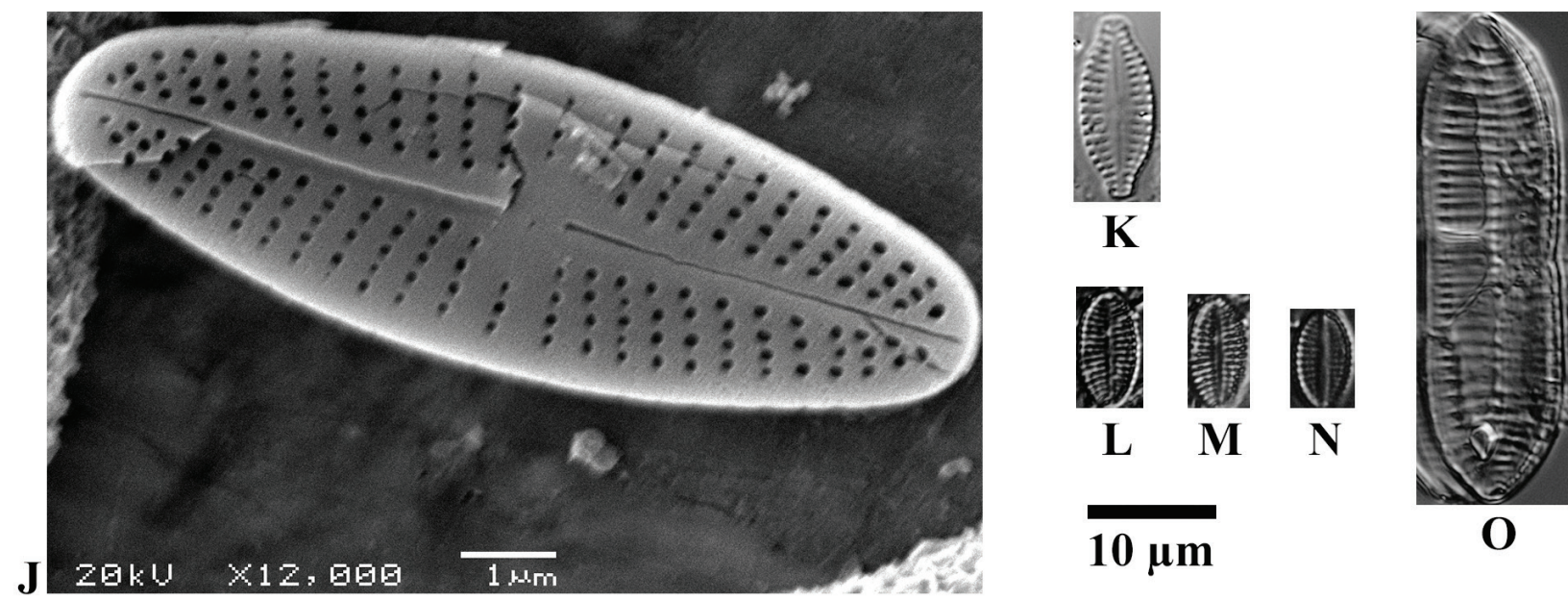

Fig. 1. New for Ukraine records of diatom species from Nyzhnosulsky National Nature Park

A: Encyonema lacustre; B, C: Gomphonema angusticephalum; D: Placoneis abiskoensis; E: P. paraelginensis; F, G: Caloneis biconstrictoides; H, I: Stauroneis balatonis; J: Achnanthidium eutrophilum; K: Karayevia kolbei; L-N: K. suchlandtii; O: Tryblionella salinarum

Placoneis paraelginensis Lange-Bert. (Fig. 1, E)

Valves linear, with somewhat convex margins. Apices subcapitate. Valve length $28.28 \mu \mathrm{m}$, valve width $7.74 \mu \mathrm{m}, \mathrm{L} / \mathrm{W}$ 3.7. Axial area very narrow and linear. Central area transversely rectangular, occupies more than $1 / 2$ valve width. Striae radiate throughout the valve, slightly wider apart at the centre of the valve, and shorter in the central area, 12 in $10 \mu \mathrm{m}$.

Ecology. Recent and fossil freshwater (Cox, 2003), occurs in waters with high level of mineralization and low level of organic matter (Bey, Ector, 2013b).
Locality. Benthos, the Sula River, Maloseletske village, Orzhytsia District, Poltava Region, NSNNP, November $2016\left(t 4{ }^{\circ} \mathrm{C}, \mathrm{pH} 7\right)$.

Distribution. Widely distributed in Europe, North and South America, Asia (AlgaeBase..., 2019).

\section{Family Gomphonemataceae Kütz.}

Gomphonema angusticephalum E. Reichardt \&LangeBert. (Fig. 1, B, C)

Valves heteropolar, broadest near the headpole but tumid at the center of the valve. Valve length 30.12$32.67 \mu \mathrm{m}$, valve width in the middle $4.62-5.13 \mu \mathrm{m}$, in 
the headpole 5.53-6.17 $\mu \mathrm{m}$. Axial area narrow, central area small, rounded with one stigma. Striae parallel, in the middle and on the ends of valves weakly radial, $12-14$ in $10 \mu \mathrm{m}$.

Ecology. Freshwater species, sensitive to pollution (Bey, Ector, 2013).

Locality. Periphyton, Drachkove Lake, Horoshyno village, Orzhytsia District, Poltava Region, NSNNP, August $2016\left(t 26^{\circ} \mathrm{C}, \mathrm{pH} 7.7\right)$.

Distribution. France, Netherlands, USA (AlgaeBase..., 2019), Russia (Kulikovskiy et al., 2015).

Family Achnanthales P.C.Siva

Родина Achnanthidiaceae D.G.Mann

Achnanthidium eutrophilum (Lange-Bert.) Lange-

Bert. (Fig. 1, J)

(= Achnanthes eutrophila Lange-Bert.)

Valve linear-elliptic with broadly rounded, nonprotracted apices. Valve length $9.69 \mu \mathrm{m}$, valve width $3.19 \mu \mathrm{m}$. Axial area narrow and linear gradually expanding toward the valve center, central area weakly developed. Striae radiate becoming denser and more strongly radiate toward the apices, 30 in $10 \mu \mathrm{m}$. Striae composed of 4-5 rounded areolae.

Ecology. Eutrophic to polyeutrophic running waters (Lange-Bertalot et al., 2017).

Locality. Plankton, the Sula River, Tarasivka village, Orzhytsia District, Poltava Region, NSNNP, February $2017\left(t 0{ }^{\circ} \mathrm{C}, \mathrm{pH} 7\right)$.

Distribution. Widely distributed in Europe; the most abundant species after Achnanthidium minutissimum s. str. (Lange-Bertalot et al., 2017).

Note. Probably this species is more widely distributed in Ukraine but often erroneously identified as Achnanthidium minutissimum s. 1 .

\section{Order Naviculales Bessey sensu Round, Crawford \& D.G.Mann}

\section{Family Pinnulariaceae D.G.Mann}

Caloneis biconstrictoides Levkov (Fig. 1, F, G)

Valves broadly lanceolate, gibbous in the middle, with rounded and not protracted apices. Valve length $28.46-30.78 \mu \mathrm{m}$, valve width $9.23-10.0 \mu \mathrm{m}$. Axial area narrow, widened near the central area. Central area wide round, with large lunate thickened macula on both sides of proximal raphe endings. Raphe distinctly lateral with central pores deflected unilaterally. Striae weakly radiate, 20 in $10 \mu \mathrm{m}$.

Ecology. Oligotraphentic species, which prefers slightly alkaline waters (Levkov et al., 2007).
Locality. Plankton and benthos, the Sula River, Maloseletske village, Orzhytsia District, Poltava Region, NNPNS, August $2016\left(t 24^{\circ} \mathrm{C}, \mathrm{pH} 8\right)$ and 2017 $\left(t 24^{\circ} \mathrm{C}, \mathrm{pH} 7.6\right)$.

Distribution. North Macedonia (Levkov et al., 2007; Levkov, Williams, 2014), Russia (Kulikovskiy et al., 2016).

Note. With respect to its valve shape, it resembles Caloneis silicula var. tumida Hust. differing from the latter mainly by the presence of macula on the central area. Caloneis schumanniana var. biconstricta (Grunow) Reichelt differs in the valve shape with distinctly triundulated valve margins and strongly protracted and cuneate apices.

\section{Family Stauroneidaceae D.G.Mann ${ }^{1}$}

Karayevia kolbei (Hust.) Bukht. (Fig. 1, K)

(= Achnanthes kolbei Hust., Kolbesia kolbei (Hust.)

Round \& Bukht. nom. illeg.)

Valves elliptical-lanceolate. Apices short, rostrate. Valve length $14.31 \mu \mathrm{m}$, valve width $5.82 \mu \mathrm{m}$. Axial area narrow lanceolate, distinct central area lacking. Striae radiate and interrupted by a marginal longitudinal line, 13 in $10 \mu \mathrm{m}$.

Ecology. Unlike $K$. ploenensis, this species occurs mainly in alkaline, $\beta$-mesosaprobic rivers (LangeBertalot et al., 2011).

Locality. Benthos, the Sula River, Maloseletske village, Orzhytsia District, Poltava Region, NSNNP, August 2017 ( $\left.t 24^{\circ} \mathrm{C}, \mathrm{pH} 5,1\right)$.

Distribution. Widely distributed in Europe, North America and Asia (AlgaeBase..., 2019).

Note. The valves shape of this species is similar to that in K. ploenensis (Hust.) Bukht., but striae of the latter species are not interrupted by a marginal longitudinal line (LangeBertalot et al., 2011).

Karayevia suchlandtii (Hust.) Bukht. (Fig. 1, L, M, N)

(= Achnanthes suchlandtii Hust., A. lewisiana R.M.Patrick, Cocconeis utermoehlii Hust., A. suchlandtii var. robusta Hust., Kolbesia suchlandtii (Hust.) J.C.Kingston).

Valves linear-elliptical. Valve length 7.3-9.2 $\mu \mathrm{m}$, valve width $3.89-4.37 \mu \mathrm{m}$. Axial area lanceolate. Central area indistinct. Striae in the middle of the valves almost parallel, becoming radiate toward apices, 18-20 in $10 \mu \mathrm{m}$.

Ecology. Occurs in oligotrophic waters; an indicator of good water quality (Lange-Bertalot et al., 2011).

${ }^{1}$ Genus Karayevia is included in a clade together with stauroneoid diatom genera such as Stauroneis, Prestauroneis, Craticula (Kulikovskiy et al., 2019). 
Locality. Plankton and benthos, the Sula River, Maloseletske village, Orzhytsia District, Poltava Region, NSNNP, May $2017\left(t 14^{\circ} \mathrm{C}, \mathrm{pH} 8,5\right)$.

Distribution. Widely distributed in Europe, North and South America, Asia, Australia and New Zealand (AlgaeBase..., 2019).

Stauroneis balatonis Pantocsek (Fig. 1, H, I)

Valves lanceolate, rhombic-lanceolate with short, slightly protracted apices. Valve length $23.81-29.57 \mu \mathrm{m}$, valve width $5.77-6.52 \mu \mathrm{m}$. Axial area very narrow, slightly widened towards valve central area. Central area with distinct stauros, narrow, not expanded towards valve margins. Raphe fissures almost straight, filiform. Transapical striae fine, indistinctly punctate, parallel to weakly radiate, low-observable in LM.

Ecology. Freshwater species (AlgaeBase..., 2019).

Locality. Plankton and periphyton, the Sula River, Maloseletske village, Orzhytsia District, Poltava Region, NSNNP, August 2017 ( $t 24^{\circ} \mathrm{C}, \mathrm{pH}$ 7.6).

Distribution. This species was recorded only in lakes Ohrid and Prespa (North Macedonia), where it occurs in sediments from various water depths; it has a broad distribution in Europe as a fossil (under the name S. smithii var. incisa Pantocsek) (Levkov et al., 2016).

\section{Order Bacillariales Hendey}

Family Bacillariaceae Ehrenb.

Tryblionella salinarum (Grunow) Pantoscek (рис. 1, O)

(= Nitzschia salinarum Grunow, $N$. calida var. salinarum (Grunow) Frenguelli, $N$. levidensis var. salinarum (Grunow) Krammer \& Lange-Bert.)

Valves broadly lanceolate, slightly concave in the middle of the valve. Apices drawn out and narrowly rounded. Valve length $37.72 \mu \mathrm{m}$, valve width $10.76 \mu \mathrm{m}$. Keel strongly excentric, with the central nodule formed by two fibulae. Fibulae 9 in $10 \mu \mathrm{m}$. Transapical ribs distinct, 12 in $10 \mu \mathrm{m}$. Striae indistinct in LM.

Ecology. This species occurs in salt-water of sea coast, brackish-water of river mouth and also in continental waters with high content of electrolytes, $\alpha$-mesosaprobe (Lange-Bertalot et al., 2011).

Locality. Periphyton, the Sula River, Maloseletske village, Orzhytsia District, Poltava Region, NSNNP, November $2016\left(t 4{ }^{\circ} \mathrm{C}, \mathrm{pH} 7\right)$.

Distribution. Widely distributed in Europe and Asia (AlgaeBase..., 2019).

Remark. The valves shape of this species is similar to that of T. levidensis W.Smith and T. calida (Grunow) D.G.Mann. However, T. levidensis has a smaller number of support ribs $(7-10$ in $10 \mu \mathrm{m})$ and $T$. calida has pronounced rostrate apices (LangeBertalot et al., 2011).

\section{Conclusions}

Ten species of diatoms were recorded for the first time in Ukraine. It is very likely that some of them have been previously found but not distinguished from the similar species. For instance, Gomphonema angusticephalum and Achnanthidium eutrophilum were formerly lumped under Gomphonema acuminatum Ehrenb. (Reichardt, 1999; Kulikovskiy et al., 2015) and Achnanthidium minutissimum (Kütz.) Czarn. (Lange-Bertalot, Metzeltin, 1996), respectively, and only recently were recognized as separate species.

Other species (e.g. Encyonema lacustre, Placoneis paraelginensis, Karayevia kolbei, K. suchlandtii, Tryblionella salinarum) are widely distributed but they have not been previously recorded in Ukraine due to the lack of detailed investigations. It should be noted that the record of T. salinarum, a species that prefers brackish waters, in the Sula River indicates the high electrolyte content of its waters. This conclusion is confirmed by hydrochemical analysis (Aqualandscape..., 2014).

Moreover, we have recorded several rare diatom species, such as Placoneis abiskoensis and Caloneis biconstrictoides. Stauroneis balatonis has a few extant records from lakes Ochrid and Prespa in North Macedonia (Levkov et al., 2016) but it is widely distributed in Europe and Asia as a fossil, known under the name $S$. smithii var. incisa Pantocsek.

Generally, the presence of the new, rare and interesting taxa in the water bodies of Nyzhniosulsky NNP may indicate its high nature conservation significance as an algal reserve.

\section{REFERENCES}

Algae of Ukraine: Diversity, Nomenclature, Taxonomy, Ecology and Geography, vol. 2. Bacillariophyta. 2009. Eds P.M. Tsarenko, S.P. Wasser, E. Nevo. Ruggel: A.R.G. Gantner Verlag K.-G., 413 pp.

AlgaeBase. World-wide electronic publication, National University of Ireland. 2019. Available at: http://www. algaebase.org (Accessed 03 May 2019).

Aqualandscape and biological diversity of the Nyzhniosulskyi National Natural Park, Ukraine. 2014. Ed. V.I. Shcherbak. Kiev: Phytosociocentre, 266 pp. [Акваландшафтное u биологическое разнообразие Национального природного парка "Нижнесульский", Украина. 2014. Ред. В.И. Щербак. Киев: Фитосоциоцентр, 266 с.].

Bąk M., Witkowski A., Zelazna-Wieczorek J., Wojtal A.Z., Szczepocka E., Szulc A., Szulc B. 2012. Klucz do oznaczania okrzemek $w$ fitobentosie na potrzeby oceny stanu ekologicznego wód powierzchniowych w Polsce. Warszawa [Warsaw]: Glowny Inspektorat Ochrony Srodowisk, $452 \mathrm{~s}$. 
Bey M.-Y., Ector L. 2013a. Atlas des diatomées des cours d'eau de la region Rhône-Alpes: Naviculacées (Naviculoidées: Adlafia, Amphipleura, Aneumastus, Anomoeoneis, Berkeleya, Brachysira, Caloneis, Cavinula, Chamaepinnularia, Craticula, Diadesmis, Didymosphenia, Diploneis, Eolimna, Fallacia, Fistulifera, Frustulia, Geissleria, Gyrosigma, Hippodonta, Kobayasiella, Luticola, Mayamaea, Naviculadicta, Neidiomorpha, Neidium, Nupela, Oestrupia, Parlibellus), vol. 3. Luxembourg: CRP-GL, 196 pp.

Bey M.-Y., Ector L. 2013b. Atlas des diatomées des cours d'eau de la region Rhône-Alpes: Naviculacées (Naviculoidées: Navicula, Pinnularia, Placoneis, Prestauroneis, Pulchella, Sellaphora, Stauroneis), vol. 4. Luxembourg: CRP-GL, 217 pp.

Bey M.-Y., Ector L. 2013c. Atlas des diatomées des cours d'eau de la region Rhône-Alpes: Naviculacées: Cymbelloidées, Gomphonématoidées, vol. 5. Luxembourg: CRP-GL, 217 pp.

Bey M.-Y., Ector L. 2013d. Atlas des diatomées des cours d'eau de la region Rhône-Alpes: Bacillariacées, Rhopalodiacées, Surirellacées, vol. 6. Luxembourg: CRP-GL, 206 pp.

Cox E.J. 2003. Placoneis Mereschkowsky (Bacillariophyta) revisited: resolution of several typification and nomenclatural problems, including the generitype. Botanical Journal of the Linnean Society, 141(1): 53-83.

Diatoms of North America. The source for diatom identification and ecology. 2018. Available at: https://diatoms.org (Accessed 14 October 2018).

Fleming W., Roy J. 1943. A high index mounting medium for microscopy. Microscopical Society, 63: 34-37.

Krammer K. 1986. Bacillariophyceae 1. Naviculaceae. In: Süßwasserflora von Mitteleuropa. Stuttgart; New York: Gustav Fischer Verlag, 876 S.

Krammer K., Lange-Bertalot H. 1989. Bacillariophyceae 2. Bacillariaceae, Epithemiaceae, Surirellaceae. In: Süßwasserflora von Mitteleuropa. Stuttgart: Gustav Fischer Verlag, $569 \mathrm{~S}$.

Krammer K. 1991. Bacillariophyceae. 4. Achnanthaceae. Kritische Erganzungen zu Navicula (Lineolatae) und Gomphonema. In: Süßwasserflora von Mitteleuropa. Stuttgart: Gustav Fischer Verlag, 437 S.

Krammer K. 1997. Die cymbelloiden Diatomeen. Eine Monographie der weltweit bekannten Taxa. 1. Allegmeins und Encyonema. In: Bibliotheca diatomologica. Berlin; Stuttgart: J. Cramer, 382 pp.

Kryvosheia O., Kapustin D. 2019. Algologia, 29(3): 298-321. [Кривошея О.Н., Капустин Д.О. 2019. Диатомовые водоросли Национального природного парка "Нижнесульский" (Украина). Альгологія, 29(3): 298-321]. https://doi.org/10.15407/alg29.03.298

Kulikovskiy M.S., Kociolek J.P., Solak C.N., Kuznetsova I. 2015. The diatom genus Gomphonema Ehrenberg in Lake Baikal. II. Revision of taxa from Gomphonema acuminatum and Gomphonema truncatum-capitatum complexes. Phytotaxa, 233(3): 251-272.
Kulikovskiy M.S., Glushchenko A.M., Genkal S.I., Kuznetsova I.V. 2016. Opredelitel diatomovykh vodorosley Rossii (Identification book of diatoms from Russia). Yaroslavl: Filigran, 804 pp. [Куликовский М.С., Глущенко А.М., Генкал С.И., Кузнецова И.В. 2016. Определитель диатомовых водорослей России. Ярославль: Филигрань, 804 с.].

Kulikovskiy M., Maltsev Y., Andreeva S., Glushchenko A., Gusev E., Podunay Y., Ludwig T.V., Tusset E., Kociolek J.P. 2019. Description of a new diatom genus Dorofeyukea gen. nov. with remarks on phylogeny of the family Stauroneidaceae. Journal of Phycology. https://doi. org/10.1111/jpy. 12810

Lange-Bertalot H., Hofmann G., Werum M. 2011. Diatomeen im Süßwasser-Benthos von Mitteleuropa. Ruggel: A.R.G. Gantner Verlag K.-G., 908 S.

Lange-Bertalot H., Hofmann G., Werum M., Cantonati M. 2017. Freshwater benthic diatoms of Central Europe: over 800 common species used in ecological assessment. English edition with updated taxonomy and added species. Eds M. Cantonati, M.G. Kelly, H. Lange-Bertalot. Schmitten-Oberreifenberg: Koeltz Botanical Books, 942 pp.

Lange-Bertalot H., Metzeltin D. 1996. Indicators of Oligotrophy. 800 taxa representative of three ecologically distinct lake types: carbonate buffered - oligodystrophicweakly buffered soft water. Iconographia Diatomologica, 2: $1-390$.

Levkov Z., Kristic S., Metzeltin D., Nakov T. 2007. Diatoms of Lakes Prespa and Ohrid. About 500 taxa from ancient lake system. Iconographia Diatomologica, 16: 1-613.

Levkov Z., Williams D.M. 2014. Observations on Caloneis Cleve (Bacillariophyceae) species from the ancient lakes Ohrid and Prespa. Nova Hedwigia, 143: 141-158. https:// doi.org/10.1127/1438-9134/2014/008

Levkov Z., Tofilovska S., Jovanovska E., Cvetkoska A., Metzeltin D. 2016. Revision of the Stauroneis smithii Grunow (Bacillariophyceae) species complex from Macedonia. Botanica Serbica, 40(2): 167-178. https:// doi.org/10.5281/zenodo.162215

Medlin L.K., Kaczmarska I. 2004. Evolution of the diatoms: V. Morphological and cytological support for the major clades and a taxonomic revision. Phycologia, 43: 245-270.

Nyzhniosulskyi National Natural Park. [Національний природний парк "Нижньосульський"]. Available at: http://nppns.at.ua (Accessed 13 November 2018).

Palamar-Mordvintseva G.M., Tsarenko P.M. 2015. Algofloristic zoning of Ukraine. International Journal on Algae, 25(4): 303-328. https://doi.org/10.1615/ InterJAlgae.v17.i4.10

Prygiel J., Coste M. 2000. Guide méthodologique pour la mise en ouvre de l'Indice Biologique Diatomées. Bordeaux: Agences de l'Eau Cemagref, 134 pp.

Reinchardt E. 1999. Zur revision der Gattung Gomphonema. In: Iconographia Diatomologica, vol. 8. Ruggell: A.R.G. Gantner K.-G., 916 pp.

Рекомендує до друку С.Я. Кондратюк 


\section{НІНА АНАТОЛІЇВНА БІСЬКО (до 70-річчя від дня народження та 50-річчя наукової діяльності)}

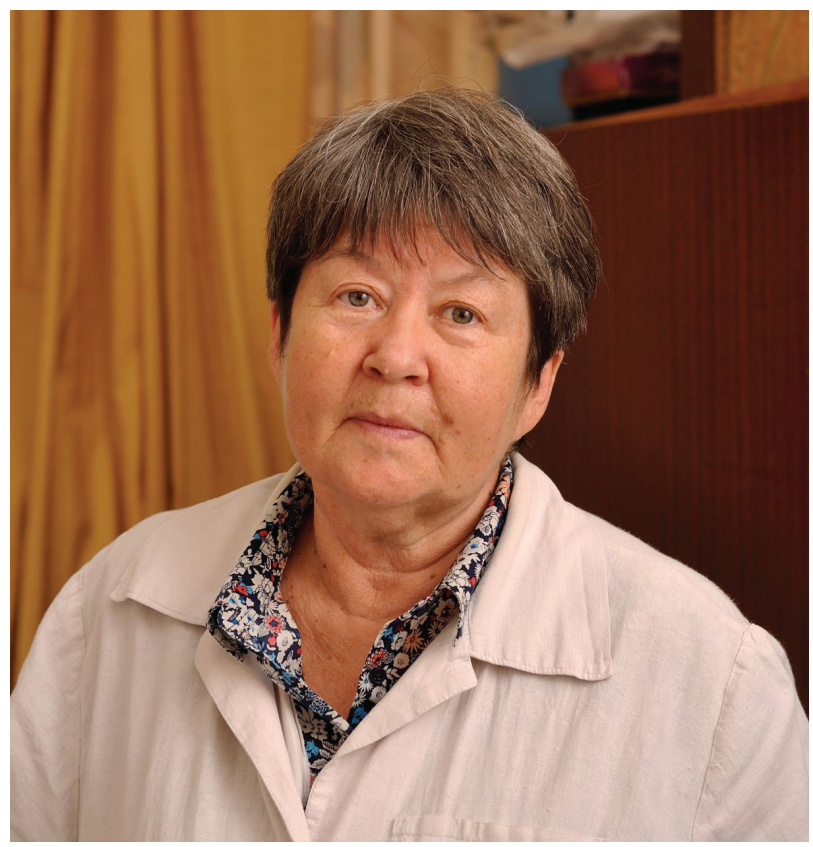

29 листопада 2019 р. виповнилося 70 років від дня народження та 50 років наукової діяльності знаного вченого в галузі біотехнології, фізіології, біохімії, екології та культивування базидієвих макроміцетів, доктора біологічних наук, лауреата Державної премії України в галузі науки і техніки, провідного наукового співробітника відділу мікології Інституту ботаніки ім. М.Г. Холодного НАН України Ніни Анатоліївни Бісько.

Народилася Ніна Анатоліївна 29 листопада 1949 р. в родині військовослужбовця в Москві. Від 1956 р. мешкала в Петропавловську-Камчатському, де служив іiі батько. Згодом батька перевели до Чернігова, де Ніна Анатоліївна закінчила середню школу із золотою медаллю. Наступного року вона вступила на біолого-грунтознавчий факультет Московського державного університету ім. М.В. Ломоносова. Після його закінчення із відзнакою в 1972 р. вступила до аспірантури біологічного факультету МДУ за спеціальністю "мікробіологія". В 1975 р. блискуче захистила кандидатську дисертацію за темою: "Биосинтез истинных восков сапрофитными микобактериями".

Наукову діяльність Ніна Анатоліївна продовжила у відділі мікології та ліхенології Інституту ботаніки ім. М.Г. Холодного АН України, куди в 1976р.булаприйнятанапосадумолодшогонаукового співробітника. 31987 р. вона працювала тут старшим, а з 1992 р. - провідним науковим співробітником. Основними напрямами наукової діяльності ювілярки є створення наукових засад сучасних технологій штучного вирощування їстівних грибів в умовах промислового виробництва, розробка основних етапів біотехнології культивування лікарських та їстівних макроміцетів у культурі, збереження генофонду макроміцетів у Колекції культур шапинкових грибів (IBK). При створенні технології вирощування їстівних грибів Н.А. Бісько опрацювала кілька основних етапів. Значна увага була приділена дослідженню фізіолого-біохімічних особливостей росту міцелію, вивченню впливу біотичних та абіотичних факторів на біохімічний склад плодових тіл та плодоношення цінних видів їстівних грибів, одержанню високоврожайних штамів вітчизняної селекції, виробництву посівного міцелію, випробуванню нехарчових компонентів субстратів, розробці оптимальних режимів культивування грибів.

3 перших кроків досліджень, пов'язаних 3 поверхневим культивуванням їстівних макроміцетів, постала необхідність упровадження одержаних результатів у практику грибівництва. Одним 3 важливих завдань було розширення асортименту культивованих грибів, оскільки на той час в Україні вирощували лише один вид печерицю двоспорову (Agaricus bisporus (J.E.Lange) Imbach). Тому в 70-80-х роках Н.А. Бісько разом із співробітниками відділу мікології розпочала роботу з уведення в промислову культуру нового об'єкта культивування - гливи звичайної (Pleurotus ostreatus 
(Jack.) Р.Kumm). Були проведені багаторічні експерименти із селекції нових вітчизняних високоврожайних штамів, підбору субстратів, встановлення оптимальних технологічних параметрів вирощування плодових тіл і посівного міцелію, дослідження взаємодії між їстівними грибами і мікроорганізмами, які домінують у субстратах. Результати цієї роботи викладені в монографії "Биология и культивирование съедобных грибов рода вешенка" (Н.А. Бісько, I.О. Дудка, 1987 р.).

Одночасно розроблялися принципи скринінгу i відбиралися перспективні для подальшої селекції штами-продуценти плодових тіл печериці та гливи. Вперше були запропоновані й апробовані схеми селекції нових високопродуктивних штамів цих грибів з використанням моно- та дикаріонів, а також фізичних мутагенів - УФ та $\gamma$-опромінення. В результаті цієї роботи у відділі мікології було одержано 4 штами печериці, які відповідають сучасним технологічним вимогам промислового вирощування, та отримано авторські свідоцтва на селектовані високоврожайні штами як печериць, так і гливи. Вперше доведена важлива роль термофільних мікроорганізмів у створенні селективних субстратів для вирошування двох видів грибів, упроваджено використання мікроорганізмів як індикаторів високоякісного компосту для вирощування печериць (термофільні мікроскопічні гриби роду Humicola) та субстрату для вирощування гливи (термофільні бактерії роду Bacillus). У результаті багаторічних досліджень було вперше показано, що при інтенсивному культивуванні біологічна цінність субстратів після плодоношення гливи збільшується за рахунок підвищення вмісту амінокислот, у тому числі незамінних, та мінеральних елементів. Розроблена технологія виробництва посівного міцелію їстівних і лікарських грибів, що включає опис технологічних етапів підготовки живильних агаризованих середовищ та зерна, параметри культивування міцелію, методику перевірки якості посівного міцелію. Результати цих досліджень узагальнено в монографії "Высшие съедобные базидиомицеты в поверхностной и глубинной культуре" (Н.А. Бісько, А.С. Бухало, І.О. Дудка та ін., 1983 р.).

У 1992 р. Н.А. Бісько захистила докторську дисертацію під назвою "Шампиньон двуспоровый Agaricus bisporus (J.E.Lange) Imbach. и вешенка обыкновенная Pleurotus ostreatus (Jacq.: Fr.) P.Kumm. в искусственных экосистемах".

Упродовж останніх десятиліть дослідження Н.А. Бісько були пов'язані з фундаментальними аспектами біології базидієвих макроміцетів в умовах культури та створенням наукових засад біотехнологічного застосування грибів цієї групи, зокрема їстівних та лікарських. На сьогоднішній день Ніна Анатоліївна зосередила дослідницьку увагу на питаннях біологічних властивостей, біосинтетичної активності, умов культивування та хімічній природі біологічно активних речовин лікарських макроміцетів. 32014 р. вона $€$ куратором Колекції культур шапинкових грибів (IBK), в якій зберігається генофонд рідкісних і зникаючих видів, а також численні біотехнологічно цінні види їстівних та лікарських грибів. У 2016 р. під керівництвом Ніни Анатоліївни був виданий новий каталог культур шапинкових грибів IBК (автори Н.А. Бісько, М.Л. Ломберг, О.Б. Михайлова, Н.Ю. Митропольська). Значна увага в Колекції культур приділена розробці нових методів одержання життєздатних культур рідкісних і зникаючих видів макроміцетів та верифікації цих культур.

Ніна Анатоліївна Бісько є автором і співавтором понад 350 наукових праць і восьми авторських свідоцтв на винаходи. Крім двох вищезгаданих монографій і каталогу, вона є співавтором таких монографічних праць, як: "Культивирование съедобных грибов" (1992р.), "Культивирование съедобных и лекарственных грибов" (2004р.), "Атлас возбудителей болезней и вредителей съедобных грибов" (2005р.), "Биологические свойства лекарственных макромицетов в культуре" у двох томах (2011-2012 pp.).

Ніна Анатоліївна веде велику науковоорганізаційну діяльність. Вона неодноразово виступала 3 доповідями на семінарах "Школи грибівництва", була членом національного оргкомітету Міжнародної конференції "Perspectives of medicinal mushrooms in health care and nutrition in the $21^{\text {th }}$ century" $(2001$ p.), брала участь у підготовці та проведенні міжнародних з'їздів, розробці методичних рекомендацій, присвячених проблемам культивування грибів у промислових умовах (1977, 1979, 1982, 1985, 1990-2019 рр.). Н.А. Бісько безпосередньо розробляла технічні умови на посівний міцелій, плодові тіла та субстрати для виробництва в Україні нових видів їстівних 
і лікарських грибів. Була ініціатором створення Всеукраїнської асоціації виробників грибів та $є$ всесвітньо визнаним науковим експертом. Завдяки iii багаторічній праці асортимент культивованих грибів в Україні на сьогоднішній день значно розширений.

Наукові здобутки Н.А. Бісько відзначені Державною премією України в галузі науки i техніки (2006р.), премією НАН України, НАН Білорусі та НАН Молдови (2008 р.).

Свою наукову діяльність Ніна Анатоліївна гармонійно поєднує із суспільно корисною працею. Вона бере участь у міжнародних конференціях, з'їздах, семінарах, є членом спеціалізованої вченої ради Інституту ботаніки, багато років була членом його профкому.
Ніна Анатоліївна 3 великою відповідальністю опікується молоддю, готуючи нове покоління вчених для країни. Вона має багато учнів, керує аспірантами, здобувачами, студентами. Захоплення наукою, широке коло творчих інтересів, ентузіазм і цілеспрямованість у роботі, постійна готовність допомогти вченим-початківцям та колегам викликають повагу співробітників.

Щиро вітаємо Ніну Анатоліївну з ювілеєм, бажаємо доброго здоров'я, творчої наснаги, наукових звершень і щастя їй та її родині!

В.П. ГЕЛЮТА, М.П. ПРИДЮК, О.Б. МИХАЙЛОВА, Г.А. АЛЬ-МААЛІ, Т.В. АНДРІАНОВА, В.П. ГАЙОВА, М.Л. ЛОМБЕРГ, Н.Ю. МИТРОПОЛЬСЬКА, Ю.Я. ТИХОНЕНКО, М.О. ЗИКОВА, М.В. ШЕВЧЕНКО, С.Л. МОСЯКІН 


\section{Пам'яті видатного педагога та науковця, професора СВІТЛАНИ СЕРГІЇВНИ МОРОЗЮК} (14.06.1937 - 07.11.2019)

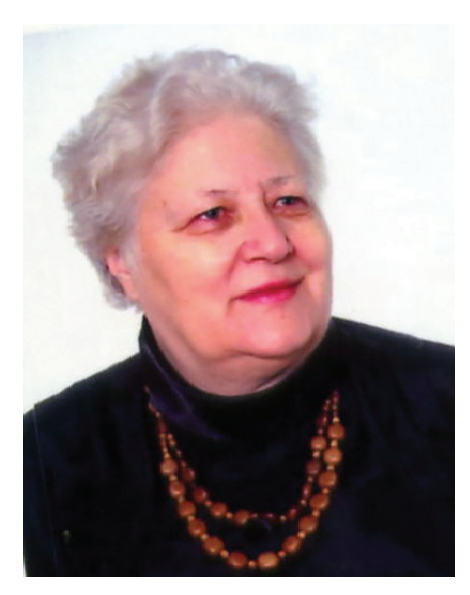

7 листопада 2019 року відійшла у вічність професор Світлана Сергіївна Морозюк - знаний науковецьботанік, талановитий педагог, популяризатор науки. Ї̈і інтереси були різнобічні - флористика, систематика, флорологія, охорона природи, історія науки, питання вищої та середньої освіти, а доробок - загальновизнаний.

С.С. Морозюк народилася 14 червня 1937 р. на мальовничій Чернігівщині в с. Березна Менського р-ну. Впродовж 1955-1960 pp. навчалася на біологічному факультеті Київського державного університету ім. Т.Г. Шевченка (нині Київський національний університет імені Тараса Шевченка). Ще в студентські роки (1959-1960) працювала молодшим науковим співробітником Ботанічного саду ім. О.В. Фоміна згаданого вишу, а в 1960 р. за розподілом була направлена до Інституту ботаніки АН УРСР (нині Інститут ботаніки ім. М.Г. Холодного НАН України). Тут пройшла шлях від старшого лаборанта до старшого наукового співробітника (1960-1975). У 1963-1968 рр. навчалася в аспірантурі Інституту під керівництвом доктора біологічних наук, професора М.I. Котова, яку успішно закінчила, захистивши в 1971 р. кандидатську дисертацію за темою "Флора крейдяних відслонень басейну p. Сіверського Дінця". Дослідниця встановила та всебічно проаналізувала видовий склад флори, дійшла висновку, шо високий відсоток ендемізму у флорі даного регіону дає підстави вважати його одним із центрів формування флори та рослинності крейдяних відслонень, розвиток яких, починаючи 3 міоцену, відбувався в основному автохтонно. Практичний аспект роботи був спрямований на створення різного рангу об'єктів природнозаповідного фонду країни для першочергової охорони найбільш цінних видів крейдяної флори: Pinus cretacea Kalenicz., Daphne sophia Kalenicz., Hedysarum ucrainicum Kaschm., Silene cretacea Fisch., Schivereckia mutabilis M.I.Alex. та ін.

Інтереси вченої також були пов'язані 3 дослідженням систематики низки родин флори України. Так, для монографії "Визначник рослин України" (1965) Світлана Сергіївна опрацювала родини Papaveraceae, Theligonaceae, Violaceae та Aristolochiaceae, для "Визначника рослин Українських Карпат" (1977) - Ranunculaceae, Aristolochiaceae, Cannabaceae, Papaveraceae, Resedaceae, Santalaceae, Violaceae, Urticaceae, для "Определителя высших растений Украины" (1987) - Actinidiaceae, Aristolochiaceae, Cannabaceae, Ebenaceae, Fumariaceae, Hypecoaceae, Juglandaceae, Lauraceae, Loranthaceae, Molluginaceae, Moraceae, Paeonicaceae, Papaveraceae, Phytolaccaceae, Portulacaceae, Ranunculaceae, Resedaceae, Santalaceae, Theligonaceae, Violaceae, Urticaceae, для монографії "Бур'яни України" - Papaveraceae та Violaceae тощо. Світлана Сергіївна також є співавтором праці "Ефіроолійні рослини України" (1969).

31975 p. С.С. Морозюк перейшла на педагогічну роботу в Київський педагогічний інститут ім. О.М. Горького (тепер Національний педагогічний університет імені Михайла Драгоманова), де працювала викладачем (1975-1978), доцентом (1978-1992) та професором (1992-2010) кафедри ботаніки природничо-географічного факультету. У 1988-2002 рр. викладала ще й на фармацевтичному факультеті Київського медичного інституту імені О.О. Богомольця (тепер Національний медичний університет імені О.О. Богомольця). У 1985-1987 pр. за угодою між Педагогічним 
інститутом і Шуменською вищою педагогічною школою (Болгарія) Світлана Сергіївна допомагала у підготовці викладачів-ботаніків для цього закладу, водночас брала безпосередню участь у вивченні флори Шуменського плато. В 1980 р. їй було присвоєно вчене звання доцента, в 1996 p. - професора. Впродовж 2010-2013 pp. С.С. Морозюк працювала професором кафедри екології Національного педагогічного університету імені Михайла Драгоманова. 32017 до 2019 рр. обіймала посаду професора кафедри біології та хімії Закарпатського угорського інституту імені Ференца Ракоці II (м. Берегове).

С.С. Морозюк розробила та викладала курси лекцій: "Ботаніка", "Фітоценологія", "Основи філогенії", "Основи біоценології" тощо. Була співавтором чисельних навчально-методичних посібників, зокрема: "Ботаніка: посібник для вчителів" (Стеблянко та ін., 1981), "Географія рослин з основами ботаніки" (Гришко-Богменко та ін., 1991), "Систематика рослин: лабораторні заняття: навчальний посібник для природничих і природничо-географічних факультетів педагогічних інститутуів" (Морозюк, Оляницька, 1988, 2001), "Польова практика з ботаніки: програма i методичні вказівки: посібник" (Морозюк та ін., 2004), "Систематика судинних рослин: курс лекцій" (Морозюк та ін., 2009) тощо. Світлана Сергї̈вна Морозюк виховала не одне покоління студентів. Керувала роботою аспірантів - Н.М. Журавель у 2005 р. захистила кандидатську дисертацію, а С.М. Білявський підготував роботу до захисту.

Світлана Сергіївна брала активну участь у розбудові шкільної біологічної освіти. Зокрема, в створенні Державного стандарту загальної середньої освіти в Україні з біології (Морозюк та ін., 1996), Програми для середньої загальноосвітньої школи: Біологія 6-11 класи (Брайон, Морозюк, 1994; Морозюк, Оляницька, 1994; Адріанов та ін., 1996, 1999), була автором першого національного підручника 3 біології для загальноосвітніх навчальних закладів (Морозюк, 1996), а також розробила до нього навчально-методичний комплекс.

Багато уваги професор С.С. Морозюк приділяла науково-методичній роботі 3 вчителями, студентами та школярами, читала лекції, надавала наукові та методичні консультації. Працювала 3 обдарованою молоддю в школах і Національному еколого-натуралістичному центрі учнівської молоді України. Понад чверть століття вона була членом журі Всеукраїнської учнівської олімпіади з біології (1977-2014), студентських біологічних олімпіад (1978-2010), Всеукраїнського турніру юних біологів (2009-2014) та конкурсу "Учитель року" (1995-2000).

Дбала вчена й про охорону природи, зокрема була співавтором Червоної книги України. Рослинний світ $(1996,2009)$, для якої опрацювала цілу низку видів: Daphne sophia, Hyssophus cretacea Dubjan., Onosma tanaitica Klokov, Rhinanthus cretaceus Vassilcz., Genista tanaitica P.A.Smirn., Linaria cretacea Fisch. ex Spreng., Elytrigia cretaceae Klokov \& Prokud., Silene cretacea Fisch. ex Spreng., Artemisia hololeuca M. Bieb. ex Besser, Scrophularia cretacea Fisch. ex Spreng., Koeleria talievievii Lavrenko, Androsace koso-polijanskii Ovcz.

Важливим напрямком діяльності С.С. Морозюк була популяризація ботанічних знань. Розповіді про чарівний світ рослин, їхні цікаві особливості, поширення, збереження тощо викладені на сторінках написаних нею у співавторстві книг: "Альбом з ботаніки" (Морозюк, Протопопова, 1979), "Трав'янисті рослини" (Морозюк, Протопопова, 1986, 2007), "Весняні рослини України" (Панова та ін., 2007), "Знайомі незнайомці та їхні цілющі соки" (Морозюк та ін., 2011), "Степові рослини України" (Панова та ін., 2015).

Загалом у науковому доробку С.С. Морозюк понад 200 наукових, освітніх і науково-популярних праць, серед яких монографії, підручники, наукові статті, навчальні посібники, якими користуються і користуватиметься не одне покоління біологів.

Світлана Сергіївна вела також активну громадсько-наукову діяльність: була членом Українського ботанічного товариства, входила до складу редколегії журналу "Біологія і хімія в школі" (з 2012 р. - "Біологія і хімія в сучасній школі"), була членом спеціалізованої вченої ради при Національному ботанічному саду ім. М.М. Гришка НАН України тощо.

За вагомий внесок у науку та освіту С.С. Морозюк удостоєна відзнак "Відмінник народної освіти УРСР" (1988) та "Відмінник освіти України" (2002), нагрудних знаків імені Василя Сухомлинського та академіка О.В. Фоміна.

Низько схиляємо голову перед світлою пам'яттю Світлани Сергіївни Морозюк. Завжди будемо Вас пам'ятати, наш Вчителю та Колего!

\section{С.М. БІЛЯВСБКИЙ, Н.М. ЖУРАВЕЛЬ, В.В. ПРОТОПОПОВА, Е.І. КОГУТ, M.B. ШЕВЕРA}

Ukrainian Botanical Journal, 2019, 76(6) 


\section{ПРАВИЛА ДЛЯ АВТОРІВ}

"Український ботанічний жмрнал" публікує оригінальні статті з усіх напрямів ботаніки та мікології, а саме: загальних проблем, флористики, геоботаніки, систематики, екології, еволюції, географії, морфології, анатомії, ембріології, фізіології, біохімії, клітинної та молекулярної біології рослин і грибів, історії науки, ботанічного ресурсознавства й охорони фіто та мікобіоти.

Рукописи приймаються українською, англійською та російською мовами (останньою - тільки від авторів 3-поза меж України).

Редакційна колегія "Украӥнського ботанічного журналу" у своїй діяльності дотримується принципів видавничої етики та керується положеннями 3 етики наукових публікацій (Committee on Publication Ethics (COPE) - http://publicationethics.org/, White Paper on Publication Ethics - http://www. councilscienceeditors.org/wp-content/uploads/entire whitepaper.pdf). Українські автори, серед іншого, мають користуватися "Етичним кодексом ученого України", прийнятим Загальними зборами НАН України 15 квітня 2009 р. (Бюлетень ВАК України, 2010, no 2, с. 2-5).

Автори при поданні рукопису несуть відповідальність за розкриття своїх прямих або непрямих фінансових i інших конфліктних інтересів, здатних вплинути на їхню роботу. У рукописі мають бути згадані всі особи й організації, що надали фінансову підтримку, а також брали у роботі особисту участь. Автори можуть вказувати імена тих, кому, на їхню думку, не слід направляти рукопис на рецензію в зв'язку з можливим, як правило, професійним конфліктом інтересів. Інформацію про наявність конфлікту інтересів редколегія може використовувати як основу для прийняття редакційних рішень.

Фальсифікація та фабрикація даних, плагіат та інші порушення наукової етики є неприпустимими.

Матеріали, подані до друку в інші видання чи вже опубліковані (повністю або частково), не приймаються i не розглядаються. Виключення може бути зроблене лише для оглядових статей, або якщо для поширення наукових знань доцільна публікація в різних журналах чи іншими мовами; в усіх таких випадках потрібні: 1) згода всіх співавторів (якщо вони є); 2) підтверджене погодження редакторів усіх задіяних видань; 3) належні посилання на оригінальні публікації.

При використанні опублікованих в "Українському ботанічному журналі" матеріалів посилання на публікацію в "Українському ботанічному журналі" є обов'язковим.

До редколегії на адресу редакції "Українського ботанічного жмунналу" secretary_ubzh@ukr.net окремими файлами потрібно надіслати: $\checkmark$ повний текст статті (з інтегрованими в нього рисунками, таблицями, рефератами) у форматах .doc, .docx або .rtf, $\checkmark$ супровідну інформацію.

Рукописи повинні відповідати стилю та редакційним стандартам "Українського ботанічного жжурналу". При підготовці рукопису просимо керуватися, крім наведених правил, також останніми номерами журналу та точно дотримуватися їхнього формату.

1. Обсяг тексту (разом зі списком літератури) для проблемно-теоретичних, критичних і дискусійних статей не може перевищувати 25, оригінальних фактологічних - 15, коротких повідомлень, рецензій, хроніки, а також статей із розділів "Ювілейні дати" та "Втрати науки" - 5 стандартних сторінок (див. п. 4). Статті, що $є$ більшими за обсягом, друкуються лише за попереднім узгодженням $з$ редколегією. Рисунки і підписи до них, таблиці та реферати не входять до цього обсягу, але вони не мають перевищувати обсяг текстової частини статті. Таблиці (синоптичні тощо), рисунки (зображення гербарних зразків тощо), додаткові матеріали (список досліджених гербарних зразків, флористичні списки), що займають багато сторінок, можуть бути опубліковані в електронному варіанті журналу як електронні додатки до статті, з посиланням на них у друкованій версії.

2. Розміщення матеріалу статті: $\checkmark$ назва статті (напівжирним, звичайним за розміром шрифтом); $\checkmark$ ім'я повністю, ініціал по батькові або ініціал другого імені (за потреби) та прізвище автора/ авторів (великими літерами, звичайним за 
насиченістю шрифтом); $\checkmark$ повна назва установи, де виконане дослідження, ії повна поштова адреса, електронні адреси авторів (останні курсивом, без підкреслення); якщо автори працюють у різних установах, цифровим надрядковим індексом пов'язати прізвище автора і місце його роботи; $\checkmark$ реферат і ключові слова англійською мовою; $\checkmark$ реферат та ключові слова українською мовою; $\checkmark$ текст статті; $\checkmark$ список посилань.

3. Структурно стаття має складатися з таких розділів: "Вступ", "Матеріали та методи", "Результати та обговорення" (або "Результати", "Обговорення"), "Висновки", в разі необхідності - "Подяки". В окремих випадках можлива модифікація розділів. Таксономічні, флористичні, проблемнотеоретичні статті та короткі повідомлення можуть бути цілісними, без виділених розділів.

4. Текст статті набирається у текстовому редакторі Word: шрифт Times New Roman; кегль 12; міжрядковий інтервал - 1,5; без переносів і вирівнювання по правому краю; усі поля -2 см; сторінки рукопису позначаються наскрізною нумерацією. Електронний файл рукопису статті повинен мати назву, яка відповідає транслітерації латиницею прізвища першого автора, наприклад, "Petrenko".

Виклад тексту має бути чітким та стислим, без довгих екскурсів і повторень.

Наукові назви таксонів рослин і грибів усіх рангів слід подавати курсивом і лише латинською мовою. При першому їхньому згадуванні в тексті - із зазначенням авторів таксонів, далі - без авторів, за винятком номенклатурно-таксономічних публікацій (за потреби), а також випадків, коли це слід зробити для уникнення таксономічної неясності чи плутанини. Авторів та ранги таксонів (наприклад, subg., subsp., var. тощо) слід наводити прямим шрифтом. При першому згадуванні видів назва роду подається повністю, надалі скорочується до однієї літери, за винятком тих випадків, коли речення розпочинається з латинської назви або ж коли йдеться про види, що належать до різних родів, назви яких починаються з однакової літери. У підписах до таблиць та рисунків родові назви рослин та грибів не скорочуються (виключення перелік кількох видів одного роду).

Імена та скорочення імен авторів таксонів рослин слід стандартизувати за "The International Plant Names Index" (http://www.ipni.org/ipni/ authorsearchpage.do), назви та авторів таксонів грибів - за "МусоBank" (http://www.mycobank.org/ quicksearch.aspx). Якщо в назві статті наводяться назви видів (або інших таксонів до родового рангу включно), авторів таксона не вказувати, а в дужках обов'язково вказати родину або таксон вищого рангу, до яких цей вид (види) або інший таксон (інші таксони) належать. Автори таксонів не наводяться i в рефератах. Як виключення, автори таксонів можуть наводитися в назві та/або рефератах лише у номенклатурно-таксономічних статтях і лише тоді, коли ця інформація є критично важливою з номенклатурної точки зору.

Фізичні величини слід наводити в одиницях СI. Для позначення інтервалу значень використовувати коротке тире (n-dash), наприклад: 5-12 см, 6080\%. У тексті повинні бути лише "англійські" лапки. Скорочення слів і словосполучень у тексті статті, в оформленні таблиць і рисунків, окрім загальноприйнятих, неприпустимі. За необхідністю скорочення можна наводити за наявності попереднього розшифрування (наприклад: Національний природний парк (НПП) і далі по тексту - НПП).

У разі морфологічних, анатомічних, палінологічних та інших досліджень слід чітко вказувати кількість використаних рослин, зразків тощо, на основі яких проводили дослідження. Обов'язково цитуються етикетки або інші ідентифікатори використаних гербарних зразків або інших об'єктів зберігання, з якими працював автор; якщо зразки чисельні, вказується лише місце зберігання (гербарій, колекція) і номери зразків. Етикетки цитуються повністю, мовою оригіналу із зазначенням (за наявності) номеру зразка або баркоду (штрихкоду, інвентарного номеру) та акроніму гербарію, в якому вони зберігаються; при цитуванні зразків з баз даних гербаріїв адреса (електронна локалізація або електронний ідентифікатор) зображення наводиться за вимогами певного гербарію або бази даних. Акроніми гербаріїв цитуються за "Index Herbariorum" (http://sweetgum.nybg.org/science/ih/) або за виданням "Гербарії України" (2011) (http:// www.botany.kiev.ua/doc/Herbarium_Ukr_2011.pdf).

Матеріалам щодо першої знахідки виду чи роду рослин і грибів на території України або будь-якої іншої країни редакція надає пріоритет. Рішення щодо публікації коротких повідомлень про нову знахідку раніше зареєстрованих таксонів редколегія приймає на свій розсуд, окремо для кожного випадку. Винятком є повідомлення про нові знахідки видів, включених до Червоної книги України. 
Літературні джерела слід цитувати у тексті у такий спосіб: П.П. Іваненко (Ivanenko, 2002); (Ivanenko, 2002); (Ivanenko, 2002, 2014a, b; Jones et al., 2004; Petrenko, Sydorova, 2010). В англомовних статтях: Jones (2008), (Jones, 2008) тощо.

Якщо одночасно наводиться декілька посилань, слід дотримуватись хронологічної послідовності. Якщо праця цитується за ії назвою, цитувати необхідно так: "...до Червоної книги України (Chervona..., 1996, 2009)"; "...в низці праць (Geobotanichne..., 1977; Opredelitel..., 1987; etc.)".

y "Висновках" надавати лише основний підсумок роботи, підкреслити іiі новизну та значущість, запропонувати напрямки подальших досліджень; уникати інформації, поданої в тексті та рефераті.

Усі матеріали, які планується оприлюднювати як електронні додатки, необхідно надавати одночасно з основним рукописом. Переконайтеся, що ці матеріали згадуються у тексті статті.

Редакція залишає за собою право вносити у текст зміни, які не впливають на зміст, вкладений у нього автором.

5. Таблиці мають бути компактними і наводитися у тексті після першого посилання. Якщо таблиця переходить на наступну сторінку, iї не розбивати, головку не дублювати. Якщо таблиця займає більше сторінки, iіi необхідно надіслати також в електронному варіанті окремим файлом, наприклад, "Petrenko_Tab04" (у разі, якщо стаття прийнята до друку). Головки таблиць повинні точно відповідати змісту граф. Матеріал, наведений у таблицях, не повинен дублюватися в тексті, але може бути частково використаний при обговоренні результатів. Назва кожної таблиці наводиться мовою статті (якщо стаття не англійською мовою) та англійською, назви родів (якщо є) не скорочуються. Таблиці в електронному додатку (за наявності) нумерувати незалежно від таблиць у тексті і позначати з додаванням літери Е: Таблиця Е1. тощо.

Усі умовні позначки та скорочення повинні бути розшифровані у виносках таблиці, навіть якщо вони також розшифровані в тексті (проте, якщо вони використовуються в наступних таблицях, можна зробити це лише у першій таблиці).

6. Ілюстрації автор розміщує в тексті статті після першого посилання на них (розмір усього файлу статті з рисунками в редакторі Word не повинен перевищувати 15 Мбайт). На кожний рисунок необхідні посилання в тексті статті. Матеріал, наведений на рисунках, не має дублюватися в тексті. Однотипні рисунки та діаграми повинні бути витримані в однаковій стилістиці. Кожна вісь повинна бути позначена та мати одиниці вимірювання; товщина ліній не повинна бути меншою за 1 пт.

У разі, якщо стаття прийнята до друку, кожну ілюстрацію також потрібно надіслати окремим повнорозмірним електронним файлом у форматі програми, 3 якою працювали автори (Statistica, Adobe Photoshop, Excel тощо) 3 назвою файлу "Petrenko_Fig01", "Petrenko_Fig02" тощо. Ілюстрації мають бути чіткими та контрастними, 3 роздільною здатністю щонайменше $\mathbf{3 0 0}$ пікселів на дюйм. Зображення у форматі .jpeg (.jpg) слід зберігати в режимі "максимальний". Якщо рисунок складається з декількох ілюстрацій, кожне окреме зображення позначати великими прямими латинськими літерами шрифтом із засічками (Times New Roman, NewtonC).

Кожна ілюстрація супроводжується підписами українською (якщо стаття не англійською мовою) та англійською, наприклад:

Рис. 1. Cannabis sativa. А: жіноча квітка; В: чоловіча квітка

Fig. 1. Cannabis sativa. A: pistillate flower; B: staminate flower У підписах слід пояснювати значення всіх умовних позначок; до мікрофотографій потрібно вказувати збільшення (у вигляді текстового пояснення та/ або добре помітного масштабного штриха або масштабної лінійки), назви родів не скорочувати.

Рисунки в електронному додатку (за наявності) нумерувати незалежно від рисунків у тексті і позначати з додаванням літери Е: Рис. Е1. тощо. Усі умовні позначки та скорочення повинні бути розшифровані, навіть якщо вони також розшифровані в тексті (проте, якщо вони використовуються в наступних рисунках, можна зробити це лише у підпису до першого).

7. Список посилань має містити лише процитовані джерела і складатися за латинською абеткою. Публікації одного автора (або групи тих же авторів) розміщуються в хронологічній послідовності. Якщо протягом року опубліковано декілька праць, вони позначаються відповідно літерами a, b, с тощо; ці літери вказуються поряд із роком публікації (1970а, 1985 b тощо). Якщо цитується не перше видання певної праці, це потрібно зазначити (4-те вид., $4^{\text {th }}$ ed. тощо). У посиланнях слід наводити всіх авторів роботи, незалежно від їхньої кількості (за винятком спільного авторства консорціумів, наприклад, Angiosperm Phylogeny Group - APG, тощо). При посиланнях на "Флори", "Червоні книги" тощо, цитування починати 3 автора/ 
авторів обробки певного таксона або таксонів, що розглядаються.

Праці, опубліковані латиницею, подаються мовою оригіналу. Для праць, опублікованих кирилицею, необхідно подавати транслітерований або перекладений латиницею бібліографічний опис. Транслітератор, яким обов'язково слід користуватися, розміщений на сайті "Українського ботанічного жмурналу": http://ukrbotj.co.ua/ tools. Зверніть увагу: транслітерація посилань українською і російською мовами відрізняється. Прізвища авторів транслітеруються так, як вони наводяться самими авторами (потрібно орієнтуватися на англомовні реферати нещодавно опублікованих праць цих авторів; для номенклатурно-таксономічних робіт - також на стандартну латинізовану форму прізвища). Якщо праця (книга, автореферат, збірка матеріалів конференціі) опублікована, наприклад, українською мовою, але має також оригінальну назву англійською, латинською тощо (наведену на титульному аркуші книги або в рефераті), то варто навести ії замість транслітерованої.

У разі потреби неопубліковані дані можуть надаватися лише у тексті статті 3 приміткою "персональне повідомлення", тільки за згодою особи, що надала інформацію і з позначенням цієї особи. Цитування дисертаційних робіт і звітів у списку посилань надавати з позначкою "рукопис", "manuscript".

\section{Список посилань оформлювати за наведеними зразками}

\section{Книги}

Zerov D.K. 1964. Flora pechinochnykh i sfahnovykh mokhiv Ukrainy. Ed. A.M. Oxner. Kyiv: Naukova Dumka, 357 pp. [Зеров Д.К. 1964. Флора печіночних і сфагнових мохів України. Відп. ред. А.М. Окснер. Київ: Наукова думка, 357 с.].

Dudka I.O, Heluta V.P., Tykhonenko Yu.Ya., Andrianova T.V., Hayova V.P., Prydiuk M.P., Dzhagan V.V., Isikov V.P. 2004. Hryby pryrodnykh zon Krymu (Fungi of the Crimean Peninsula). Ed. I.O. Dudka. Kyiv: Phytosociocentre, 452 pp. [Дудка I.О., Гелюта В.П., Тихоненко Ю.Я., Андріанова Т.В., Гайова В.П., Придюк М.П., Джаган В.В., Ісіков В.П. 2004. Гриби природних зон Криму. Ред. І.О. Дудка. Київ: Фітосоціоцентр, 452 с.].

Wettstein R. 1935. Handbuch der Systematischen Botanik. Leipzig; Wien: Franz Deutike, 994 S.

\section{Окрема книга з багатотомного видання}

Didukh Ya.P., Korotchenko I.A., Fitsailo T.V., Burda R.I., Moysiyenko I.I., Pashkevich N.A., Iakushenko D.M., Shevera M.V.2010. Ekoflora Ukrainy (Ekoflora of Ukraine), vol. 6. Ed. Ya.P. Didukh. Kyiv: Phytosociocentre, 422 pp.
[Дідух Я.П., Коротченко І.А., Фіцайло Т.В., Бурда P.I., Мойсієнко I.I., Пашкевич Н.А., Якушенко Д.М., Шевера М.В. 2010. Екофлора України, т. 6. Відпов. ред. Я.П. Дідух. Київ: Фітосоціоцентр, $422 \mathrm{c.}]$.

Neyburg M.F. 1948. Verkhnepaleozoyskaya flora Kuznetskogo basseyna. In: Paleontologiya SSSR, vol. 12, part 3, issue 2. Moscow; Leningrad: Izdvo AN SSSR, 418 pp. [Нейбург М.Ф. 1948. Верxнепалеозойская флора Кузнецкого бассейна. В кн.: Палеонтология СССР, т. 12, ч. 3, вып. 2. Москва; Ленинград: Изд-во АН СССР, 418 с.].

\section{Частина книги}

Protopopova V.V. 2009. Dactylorhiza cordigera. In: Chervona knyha Ukrainy. Roslynnyi svit (Red Data Book of Ukraine. Plant Kingdom). Ed. Ya.P. Didukh. Kyiv: Globalconsulting, p. 565. [Протопопова В.В. 2009. Dactylorhiza cordigera. В кн.: Червона книга України. Рослинний світ. Ред. Я.П. Дідух. Київ: Глобалконсалтинг, с. 565].

Gymez A., Lunt D.H. 2006. Refugia within refugia: patterns of phylogeographic concordance in the Iberian Peninsula. In: Phylogeography of Southern European Refugia. Eds S. Weiss, N. Ferrand. Dordrect: Springer, pp. 155-188.

\section{Періодичні видання}

Mosyakin S.L. 2018. The correct name in Knowltonia for an iconic southern African species earlier known as Anemone tenuifolia and A. capensis (Ranunculaceae). Ukrainian Botanical Journal, 75(3): 230-237. https:// doi.org/10.15407/ukrbotj75.03.230

Mosyakin S.L. 2002. Ukrainian Botanical Journal, 59(6): 696-701. [Мосякін С.Л. 2002. Система та фітогеографія Chenopodium L. subgen. Blitum (L.) I. Hiitonen (Chenopodiaceae). Український ботанічний журнал, 59(6): 696-701].

Didukh Ya.P., Alioshkina U.M. 2007. Ukrainian Phytosociological Collection. Series C. Phytoecology, 25: 4-17. [Дідух Я.П., Альошкіна У.М. 2007. Оцінка енергетичного балансу екосистем Києва та його зеленої зони. Український фітоценологічний збірник. Серія С. Фітоекологія, 25: 4-17].

\section{Дисертації / Автореферати дисертацій}

Prydiuk M.P. 2018. Mushrooms of the families Bolbitiaceae and Psathyrellaceae of Ukraine: species composition, distribution, evolution: Dr. Sci. Diss. Kyiv, M.G. Kholodny Institute of Botany NAS of Ukraine, 368 pp. (manuscript). [Придюк М.П. 2018. Гриби родин Bolbitiaceaema та Psathyrellaceae України: видовий склад, поширення, еволюція: дис. ... д-ра. біол. наук: спец. 03.00.21 "Мікологія". Київ, Інститут ботаніки ім. М.Г. Холодного НАН України, 368 с. (рукопис)].

Kucher O.O. 2016. The alien fraction of the flora of the Starobilsk Grass-meadow Steppe and its invasive potential: Cand. Sci. Diss. Abstract. Kyiv, M.G. Kholodny Institute of Botany NAS of Ukraine, 18 pp. [Кучер O.O. 2016. Адвентивна фракція флори Старобільського злаково-лучного степу та іії інвазійний потенціал: автореф. дис. ... канд. біол. наук: спец. 03.00.05 "Ботаніка". Київ, Інститут ботаніки ім. М.Г. Холодного НАН України, 18 с.].

Ukrainian Botanical Journal, 2019, 76(6) 


\section{Електронні ресурси}

IPNI. The International Plant Names Index. 2012-onward. Available at: http://www.ipni.org (Accessed 21 March 2019).

Halbritter H., Svojtka M. 2016. Dipsacus laciniatus. In: PalDat - a palynological database. Available at: https://www. paldat.org/pub/Dipsacus_laciniatus/30180 (Accessed 17 July 2018).

Посилання можна наводити безпосередньо в тексті (особливо за відсутності автора публікації) як http / https адресу, наприклад: "...назви видів наведено за https://www.tropicos.org/ та за http:// www.indexfungorum.org/names/names.asp"

\section{Матеріали конференцій, семінарів}

Davydov D.A. 2018. In: Classification of vegetation and biotopes of Ukraine: the Third Ukrainian Scientifictheoretical Conference proceedings. Eds Ya.P. Didukh, D.V. Dubyna. Kyiv, pp. 124-129. [Давидов Д.А. 2018. Фітосоціологічна номенклатура в Україні: сучасний стан та перспективи подальшого розвитку. В зб.: Класифікація рослинності та біотопів України: матеріали третьої науково-теоретичної конференціі (Київ, 19-21 квітня 2018 р.). Ред. Я.П. Дідух, Д.В. Дубина. Київ, с. 124-129].

8. Реферати оформлювати таким чином: $\checkmark$ прізвище й ініціали автора/авторів; $\checkmark$ назва статті (напівжирним шрифтом); $\checkmark$ повна назва установи, де виконане дослідження, ii повна поштова адреса; якщо автори працюють у різних установах, цифровим надрядковим індексом пов'язати прізвище автора і місце його роботи (якщо стаття українською мовою, ці дані надавати лише в англомовному рефераті, якшо - англійською, тільки в україномовному); $\checkmark$ текст реферату; $\checkmark$ ключові слова. $\checkmark$ посилання на електронний додаток (Supplementary Material) за необхідності.

Текст реферату (не менше 1800 знаків) повинен мати чітку структуру, бути змістовним, інформативним, логічно вибудуваним, тобто давати повне уявлення про роботу; не повинен дублювати висновки; слід уникати скорочень (крім загальноприйнятих) та посилань.

Ключові слова (не більше восьми) наводяться в абетковій послідовності кожної з мов, друкуються прямим шрифтом, латинські назви - курсивом, відокремлюються комами. Бажано уникати повторення слів із назви статті.

\section{9. Супровідна інформація.}

На окремому аркуші (окремим файлом "Petrenko_Info") обов'язково надаються відомості про всіх авторів статті: $\checkmark$ прізвище, ім'я та по батькові повністю українською та англійською мовами (окремо позначається автор, який листуватиметься 3 редакцією); $\checkmark$ науковий ступінь і посада; $\checkmark$ контактні номери телефонів; $\checkmark$ адреси електронної пошти.

До статей аспірантів обов'язкова рекомендація наукового керівника.

10. Праці, в яких описуються нові таксони, повинні містити інформацію про гербарій, до якого здано на зберігання голотипи цих таксонів. Ізотипи передаються до Національного гербарію України (гербарію Інституту ботаніки імені М.Г. Холодного НАН України - KW). При повідомленні про флористичні знахідки у статті необхідно вказати, у гербарії якої наукової установи зберігаються гербарні зразки, а також, за наявності, надати їхні унікальні ідентифікатори (наприклад, номери зборів того чи іншого колектора або баркод, інвентарний номер гербарію або інший цифровий ідентифікатор).

Якщо в статті згадується про спеціальне використання (добування, збирання) у наукових цілях об'єктів Червоної книги України, у редакцію необхідно надати копію дозволу згідно з Законом України про Червону книгу України (https://zakon. rada.gov.ua/laws/show/3055-14, див. Розділ V).

11. Реєстрація цифрового ідентифікатору об'єкту (DOI) для статей, що публікуються в "Украӥнському ботанічному журналі", є платною. Умови оплати редакція повідомляє авторам після прийняття статті до друку.

Статті, оформлення яких не відповідає правилам, не приймаються і не розглядаються.

Подані рукописи підлягають односторонньому "сліпому" рецензуванню (single-blind review) двома рецензентами та науковому редагуванню.

Редколегія залишає за собою право беззаперечно відхиляти статті на основі негативних анонімних або відкритих рецензій чи експертних висновків членів редколегії або інших фахівців.

Автори зобов'язані надавати обгрунтовані та аргументовані відповіді на зауваження рецензентів та наукового редактора.

Після повернення авторами остаточної верстки зміни до тексту не приймаються.

Правила для авторів англійською та українською мовами в електронному вигляді доступні на http://ukrbotj.co.ua/guidelines 


\section{Систематика, флористика, географія рослин}

Безусько Л.Г., Цимбалюк 3.М., Мосякін С.Л., Ниценко Л.М. Участь Ceratocarpus arenarius (Chenopodiaceae) у пізньольодовикових та голоценових палінофлорах рівнинної частини України . . . . . . . . . . . 5 418-426

Красняк О.І., Федорончук М.М. Ознаки будови епідерми пластинки листка в таксономії видів та родів триби Bromeae (Роасеае) флори України . . . . . . . . . . . . . . . . . . . . . . . . . . . . . . . . . $3 \quad 189-210$

Федорончук M.M. Конспект родини Fabaceae у флорі України. IV. Підродина Faboideae (триби: Cicereae,

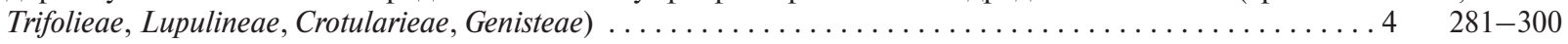

Цимбалюк 3.М., Безусько Л.Г., Мосякін С.Л., Ниценко Л.М. Паліноморфологія видів роду Dipsacus (Dipsacaceae) флори України: значення для цілей систематики та спорово-пилкового аналізу ..... 1 9-23

de Lange P.J., Mosyakin S.L. Trithuria brevistyla (Hydatellaceae), a new combination for the New Zealand endemic

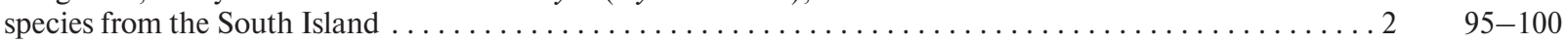

Krasylenko Yu.A., Gleb R.Yu., Volutsa O.D. Loranthus europaeus (Loranthaceae) in Ukraine: an overview of distribution

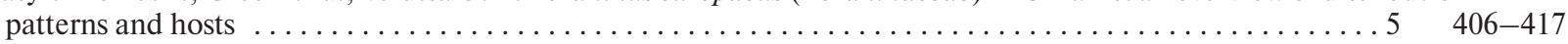

Mosyakin S.L., Boiko G.V., Glukhova S.A. Artemisia verlotiorum (Asteraceae) in the continental part of Ukraine: now

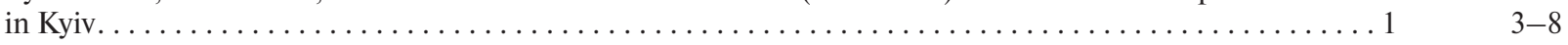

Mosyakin S.L., McNeill J., Boiko G.V. Comments on proper type designation for names of taxa validated by

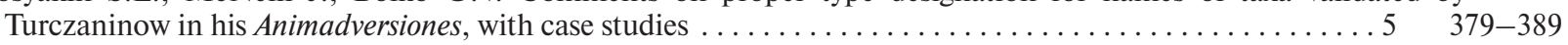

Mosyakin S.L., Shiyan N.M. Nomenclatural and taxonomic notes on Jacobaea borysthenica (Asteraceae) and some

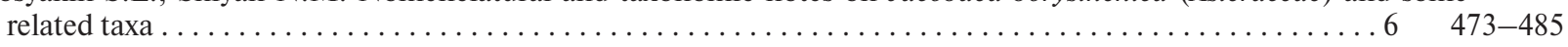

Zander R.H. Infraspecific molecular trees are associated with serial macroevolution in Pottiaceae (Bryophyta) . $5 \quad 390-405$

\section{Гриби і грибоподібні організми}

Бороменський Д.О., Бісько Н.А. Мікроморфологічні особливості грибів роду Ganoderma (Ganodermataceae)

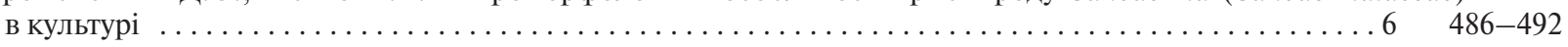

Гелюта В.П. Поширення в Україні Phallus hadriani (Phallales, Basidiomycota) $\ldots \ldots \ldots \ldots \ldots \ldots \ldots \ldots 124-30$

Дармостук В.В. Рід Lichenoconium (Lichenoconiaceae, Ascomycota) в Україні . . . . . . . . . . . . ...2 101-113

Дармостук В.В. До вивчення ліхенофільної мікобіоти України: рід Zwackhiomyces (Xanthopyreniaceae,

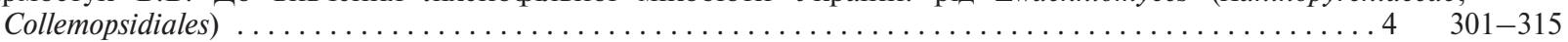

Макаренко Я.М. Гриби порядків Agaricales, Boletales і Russulales басейну річки Псел . . . . . . . . ... 3 211-219

Медведєв Д.Г., Кернер А.О., Бондарук С.В., Аль-Маалі Г.А. Дослідження культуральних особливостей та фунгіцидної резистентності штамів Cladobotryum mycophilum (Hypocreales, Ascomycota) - вперше виявленого на промислових культурах печериці в Україні збудника павутинної цвілі $\ldots \ldots \ldots \ldots \ldots \ldots \ldots \ldots 2 \quad 121-131$

Пасайлюк М.В. Біологічні особливості рідкісного гриба Sparassis nemecii (Sparassidaceae, Polyporales) на

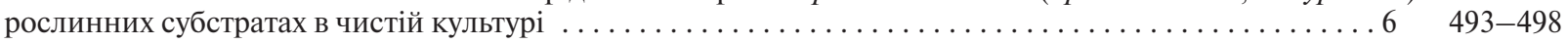

Heluta V.P., Assyov B., Hayova V.P. Distribution and preliminary assessment of a rare fungus Hemileccinum depilatum (Boletales, Basidiomycota) in Ukraine .................................... $427-433$

Regeda L.V., Bisko N.A. Micromorphological characteristics of the species of Pholiota (Strophariaceae, Basidiomycota)

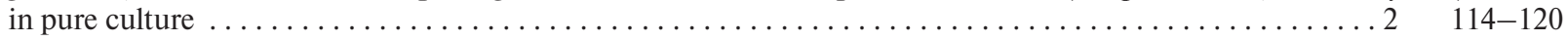

\section{Геоботаніка, екологія, охорона рослинного світу}

Дідух Я.П. Епіфітні бріоценози у біотопах неморальних лісів . . . . . . . . . . . . . . . . . 2 132-143

Дубина Д.В., Еннан А.А.-А., Дзюба Т.П., Вакаренко Л.П., Шихалєєва Г.М. Нові синтаксони степової

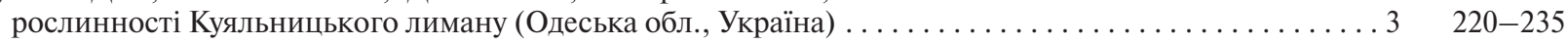

Дубина Д.В., Ємельянова С.М., Дворецький Т.В., Дзюба Т.П., Тимошенко П.А. Адвентизація ценофлор класів

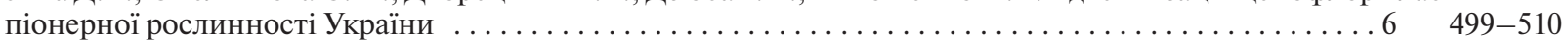

Єременко Н.С. Сингенетичні зміни рудеральної рослинності Кривого Рогу . . . . . . . . . . . . . . . . 1 31-41

Конайкова В.О. Угруповання класу Festuco-Brometea природного заповідника "Єланецький степ" . . . . 6 511-525

Шевчик В.Л, Шевчик Т.В. Фітоценотична характеристика угруповань із участю Amorpha fruticosa (Fabaceae) у

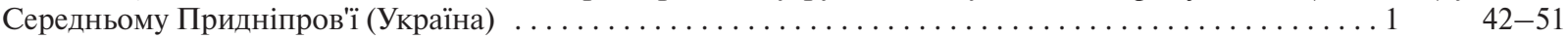


Устименко П.М., Попович С.Ю., Дубина Д.В. Сучасні тенденції динаміки раритетних фітоценозів України та

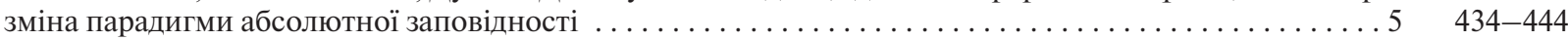

Kučera P. Syntaxonomical classification of wet woodlands with Picea abies in Slovakia . . . . . . . . . . . . . 4 $4316-343$

\section{Червона книга України}

Гелюта В.П., Зикова М.О. Поширення в Україні деяких видів Phallales (Basidiomycota), включених до Червоної книги України . .....................................................2 152-161

Мойсієнко І.І., Данилик І.М., Мельник Р.П., Садова О.Ф., Захарова М.Я. Schoenoplectiella mucronata (Сурегасеае) у флорі України ............................................. 52 . 59

Попович С.Ю., Михайлович Н.В., Грисюк Т.С. Репрезентованість Pinus cembra (Pinaceae) в природно-

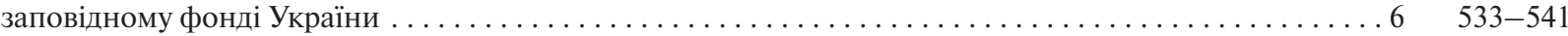

Ходосовцев О.С., Дармостук В.В., Мойсієнко І.І., Захарова М.Я., Деркач О.М. Fulgensia desertorum (Teloschistales, Ascomycota) та інші вразливі види лишайників в угрупованні Toninio-Psoretum decipientis . . . . . . . . . . $3236-242$

Юречко Р.Ю. Сучасний стан популяції Cochlearia pyrenaica (Brassicaceae) у Національному природному парку "Північне Поділля" . . . . . . . . . . . . . . . . . . . . . . . . . . . . . . . . . . . . . . . . . . . . . . 3 243-251

Roleček J., Dřevojan P. New data on distribution of the endangered species Viola jooi (Violaceae) in Ukraine $6 \quad 526-532$ Shevchenko M.V., Heluta V.P., Hayova V.P. Distribution and conservation status of Grifola frondosa (Polyporales, Basidiomycota $)$ in Ukraine . . . . . . . . . . . . . . . . . . . . . . . . . . . . . . . . . . . . . . .. 2 $144-151$

\section{Флористичні знахідки}

Куземко А.А., Яворська О.Г., Ковтонюк А.I. Cephalaria gigantea (Caprifoliaceae) - новий адвентивний вид

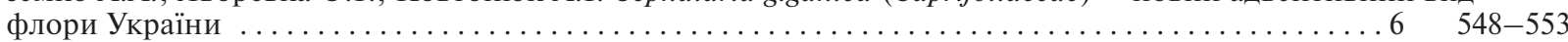

Орлов О.О., Якушенко Д.М., Маєкова Я., Заліберова М., Протопопова В.В., Андрик Є.Й., Шевера М.В. Galeopsis angustifolia (Lamiaceae) - новий адвентивний вид у флорі України . . . . . . . . . . . . . 6 542-547

Huseynova A.Y., Aghayeva P.N., Qarakhani P.Kh., Alizade V.M. Serratula coronata (Asteraceae) - a new species record

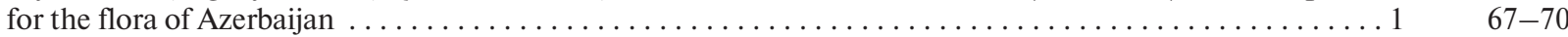

Kryvosheia O.M., Kapustin D.O. New records of diatoms for the algal flora of Ukraine from water bodies

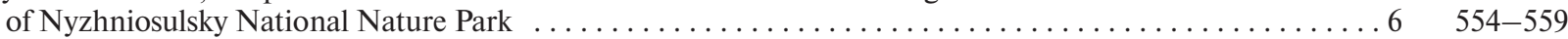

Kučera P. Salix appendiculata (Salicaceae) found in the Western Carpathians in Slovakia . . . . . . . . . . . . . 2 $2162-166$

Pachschwöll C., Pachschwöll T. A new find of Arabidopsis neglecta (Brassicaceae) in the Svydovets Massif (Ukrainian Carpathians) . . . . . . . . . . . . . . . . . . . . . . . . . . . . . . . . . . . . . . . . . . . 1 60-66

\section{Мікологічні знахідки}

Демченко Е.М. Нові для України види хітридієвих грибів (Chytridiomycota), що паразитують на

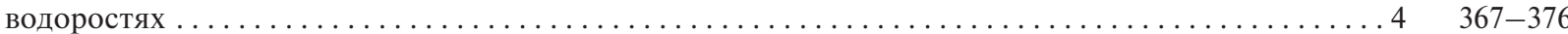

Придюк М.П. Нові та рідкісні для України таксони родів Conocybe i Pholiotina (Bolbitiaceae,

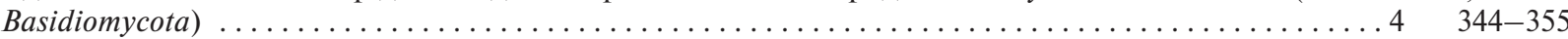

Фокшей C.I., Держипільський Л.М. Рідкісні види макроміцетів з урочища Каменистий (Національний природний парк "Гуцульщина") . . . . . . . . . . . . . . . . . . . . . . . . . . . . . . . . . . . . . . . . . . . . 4 362-366

Heluta V.P., Makarenko N.V., AlMaali G.A. First records of Erysiphe corylacearum (Erysiphales, Ascomycota) on Corylus avellana in Ukraine . . . . . . . . . . . . . . . . . . . . . . . . . . . . . . . . . . . . . . . . 3 252-259

Mustafabayli E.H., Aghayeva D.N. New records of mushrooms for the mycobiota of Azerbaijan ........ 4 356-361

Tykhonenko Yu.Ya., Hayova V.P. First records of Puccinia bornmuelleri (Pucciniales) in Ukraine …..... 5 445-450

\section{Фізіологія, біохімія, клітинна та молекулярна біологія рослин}

Аль-Маалі Г.А., Веденичова Н.П., Бісько Н.А., Косаківська І.В. Вплив мікроелементів на вміст цитокінінів у міцеліальній біомасі лікарського гриба Trametes versicolor (Polyporaceae, Basidiomycota) . . . . . . 1 71-78

Бойко С.М. Ступінь генетичної диференціації локальних популяцій Schizophyllum commune (Agaricales, Basidiomycota) південної частини Києва . . . . . . . . . . . . . . . . . . . . . . . . . . . . . . . . . . . . 5 451-457

Зубровська О.М., Гришко В.М. Інтенсивність процесів пероксидного окиснення ліпідів та функціональний стан деревних насаджень при забрудненні довкілля важкими металами $\ldots \ldots \ldots \ldots \ldots \ldots \ldots \ldots . \ldots \ldots 458-468$

Косаківська І.В., Войтенко Л.В., Васюк В.А., Щербатюк М.М., Романенко К.О., Бабенко Л.М. Гормональний комплекс гаметофітів папороті Dryopteris filix-mas (Dryopteridaceae) в культурі in vitro . . . . . . . . . . 3 260-269 


\section{Хроніка}

Гамор Ф. Міжнародна науковопрактична конференція: "Проблеми збереження гірських екосистем та сталого використання біологічних ресурсів Карпат" (до 50-річчя створення Карпатського біосферного

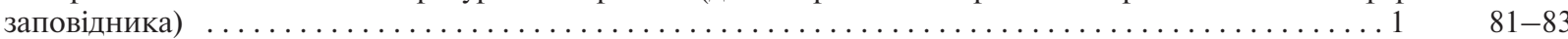

Зав'ялова Л.В., Кучер О.О., Когут Е.І., Андрик Є.Й., Кіш Р.Я., Джахман Р.В., Біланич М.М., Тюх Ю.Ю., Гамор Ф. ХІІ Міжнародна наукова конференція "Синантропізація флори і рослинності" (Ужгород - Берегове,

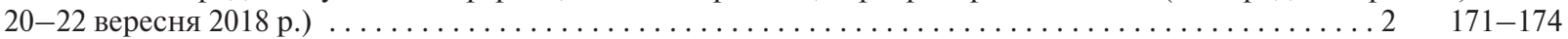

Зав'ялова Л.В., Сенчило О.О., Коломійчук В.П., Кучер О.О. Вшанування пам'яті

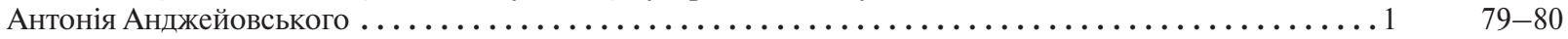

Тасєнкевич Л.О., Шиян Н.М., Хміль Т.С., Мосякін С.Л. Міжнародна наукова конференція "Гербарії та збереження фіторізноманіття" (3-5 жовтня 2018 р., Львів, Україна) . . . . . . . . . . . . . . . . . . . 2 2 167-170

\section{Ювілейні дати}

Дідух Я.П., Устименко П.М., Куземко А.А., Вакаренко Л.П., Дзюба Т.П., Ємельянова С.М., Винокуров Д.С.

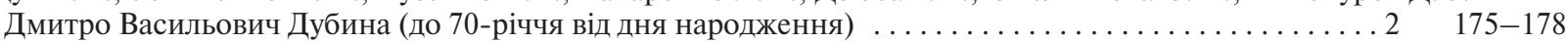

Гелюта В.П., Придюк М.П., Михайлова О.Б., АльМаалі Г.А., Андріанова Т.В., Гайова В.П., Ломберг М.Л., Митропольська Н.Ю., Тихоненко Ю.Я., Зикова М.О., Шевченко М.В., Мосякін С.Л. Ніна Анатоліївна Бісько (до 70-річчя від дня народження та 50 -річчя наукової діяльності $\ldots \ldots \ldots \ldots \ldots \ldots \ldots \ldots 6$. $560-562$

Царенко П.М., Михайлюк Т.І., Вірченко В.М., Нипорко С.О. Сергій Якович Кондратюк (до 60-річчя від дня

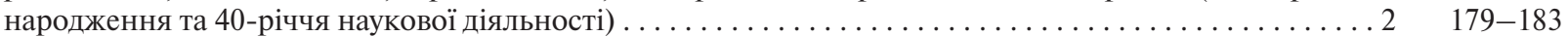

Шевера М.В., Протопопова В.В., Оптасюк О.М. Педагогу та вченому Людмилі Григорівні

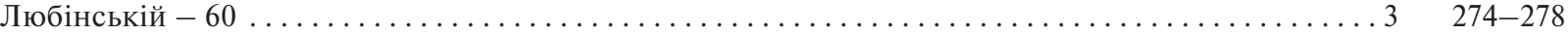

Шиян Н.М., Мосякін С.Л. Світовий знавець Cruciferae/Brassicaceae (до 80-річного ювілею Ісана Аль-

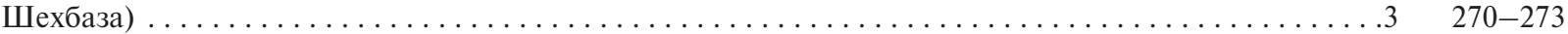

\section{Втрати науки}

Білявський С.М., Журавель Н.М., Протопопова В.В., Когут Е.І., Шевера М.В. Пам'яті видатного педагога та науковця, професора Світлани Сергіївни Морозюк $(14.06 .1937-07.11 .2019) \quad \ldots \ldots \ldots \ldots \ldots .666563-564$

Шевера М.В., Протопопова В.В., Заліберова М., Маєкова Я., Тохтарь В.К., Ростанський А. Пам'яті чеського ботаніка доктора Владіміра Єгліка $(1940-2019)$. . . . . . . . . . . . . . . . . . . . . . . . . . . . . . . 5 469-470

\section{Рещензї̈ та новини літератури}

Протопопова В.В., Устименко П.М. Рещензія на книгу: Васильева Т.В., Эннан А.А.-А., Шихалеева Г.Н. Сосудистые растения побережья Куяльницкого лимана . . . . . . . . . . . . . . . . . . . . . . . . . . . 18

Шиян Н.М., Шумілова А.В. Рецензія на книгу: Михаил Григорьевич Попов: Жизнь - дорога, счастье - конь,

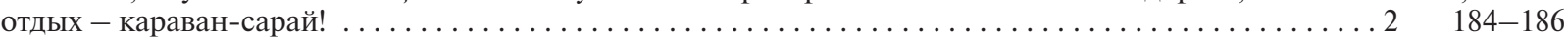

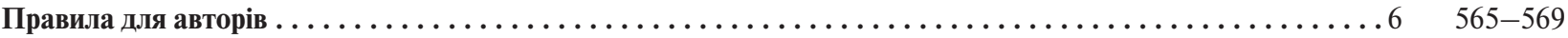

Покажчик статей, опублікованих в "Українському ботанічному журналі" в 2019 році . . . . . . . . . . . . . 6 $570-572$ 
Український ботанічний журнал, т. 76, № 6, 2019. Національна академія наук України. Інститут ботаніки ім. М.Г. Холодного. Науковий журнал. Заснований у 1921 р. Виходить один раз на два місяці (українською, англійською та російською мовами). Головний редактор С.Л. Мосякін

Затверджено до друку вченою радою Інституту ботаніки ім. М.Г. Холодного НАН України (протокол № 15 від 17 грудня 2019 року)

Реєстраційне свідоцтво серії КВ № 12179-1063ПР від 11.01.2007 р.

Редактор О.В. Пилипенко

Технічний редактор О.С. Бондаренко

Комп'ютерна верстка Д.С. Решетников

Формат 84×108/16. Ум.-друк. арк. 9,0. Обл.-вид. арк. 11,5. Тираж 176 прим. Зам. №

Віддруковано ВД "Академперіодика" НАН України

вул. Терещенківська, 4, Київ 01004

Свідоцтво суб’єкта видавничої справи ДК № 544 від 27.07.2001 
Electronic Supplement to: Mosyakin \& Shyian. Nomenclatural and taxonomic notes on Jacobaea borysthenica... Ukrainian Botanical Journal, 2019, 76(6): 473-485.
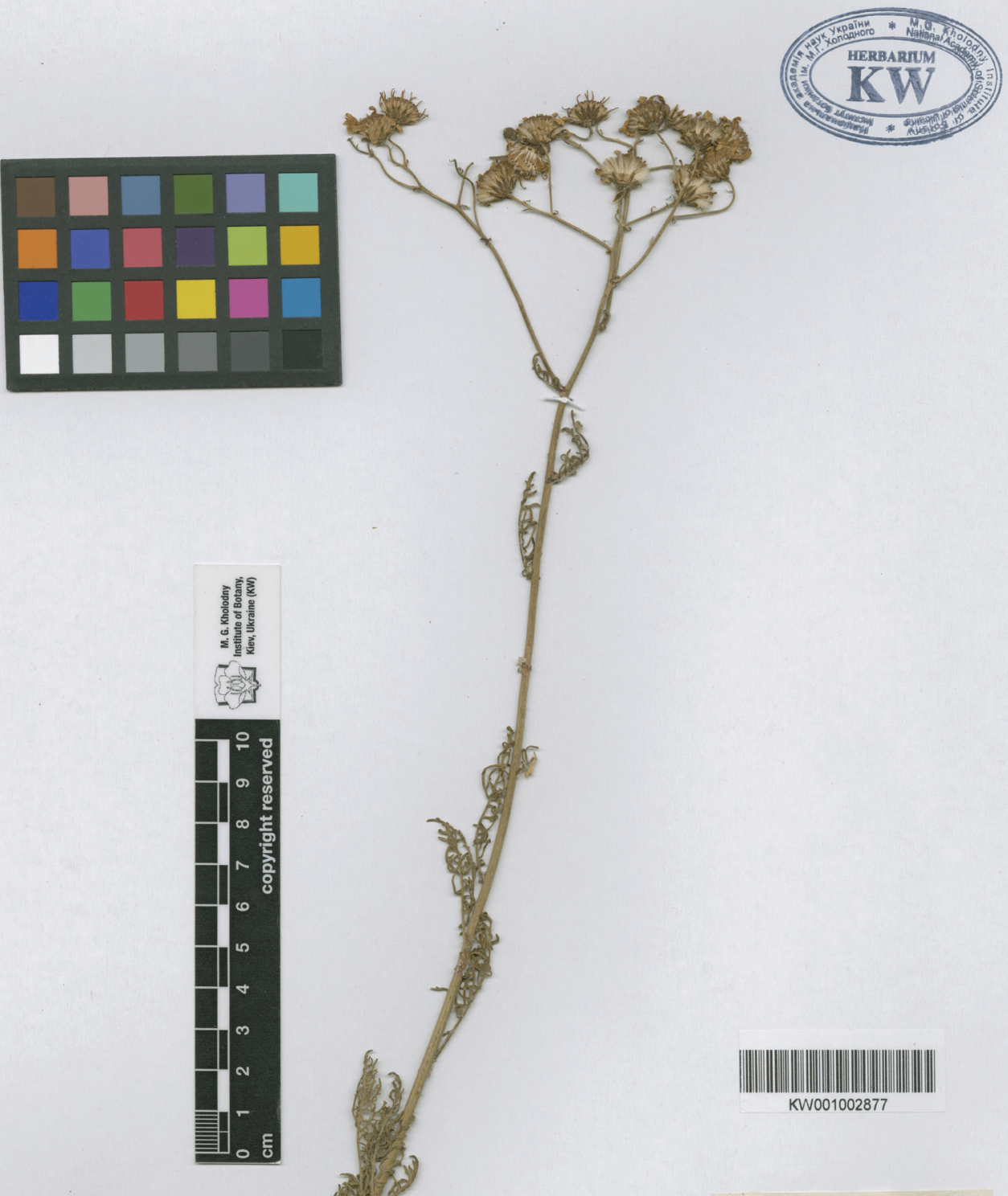

[- -3

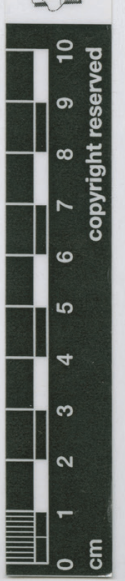

KW001002877
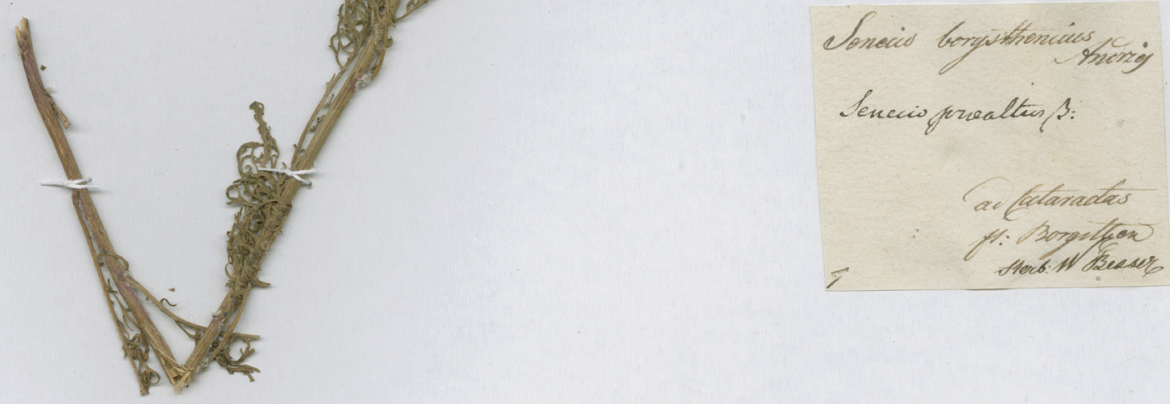

Figure 1E. A specimen of "Senecio borysthenicus Andrzej." from the Turczaninow herbarium in KW (received by Turczaninow from Besser), collected by Andrzejowski at cataracts of the Dnipro (present-day Zaporizhzhya Region), KW001002877. 


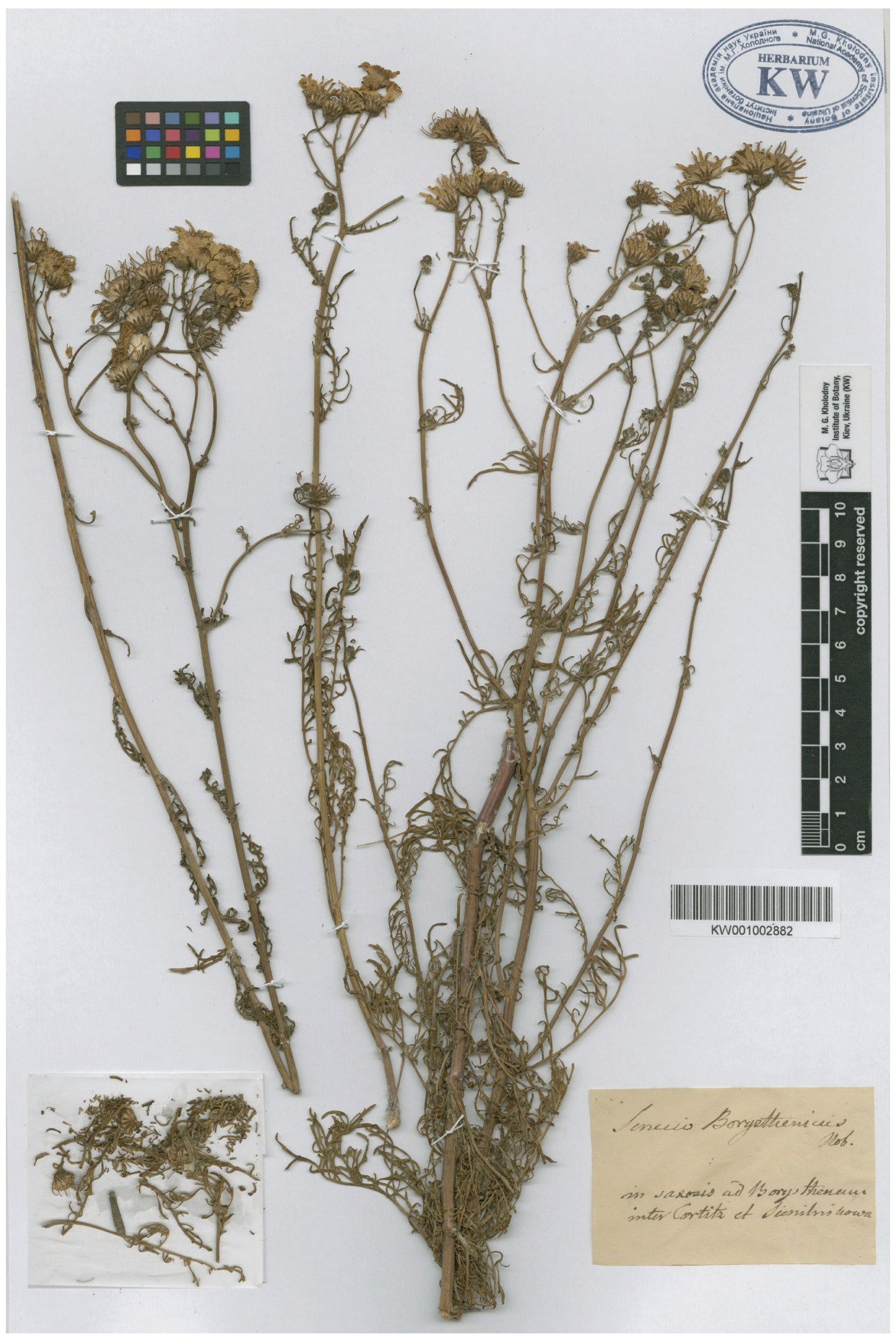

Figure 2E. A specimen of "Senecio borysthenicus Nob." from the Turczaninow herbarium in KW, collected by Andrzejowski in or near the present-day city of Zaporizhzhya, KW001002882. 


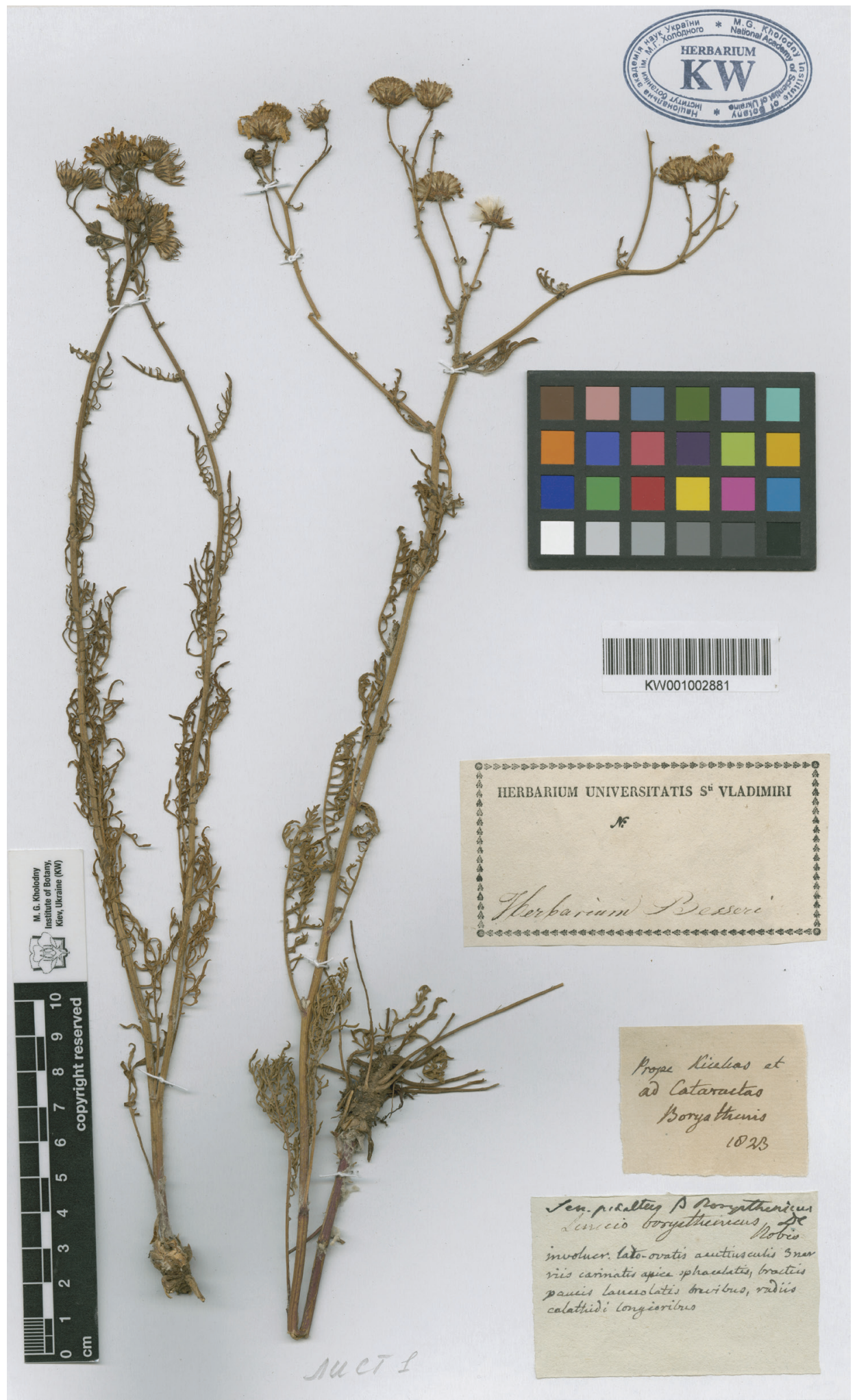

Figure 3E. A specimen labeled as "Sen. praealtus $\beta$ Borysthenicus" from the Besser herbarium in KW, collected by Andrzejowski near cataracts of the Dnipro in or near the present-day city of Zaporizhzhya, sheet 1 (KW001002881). 


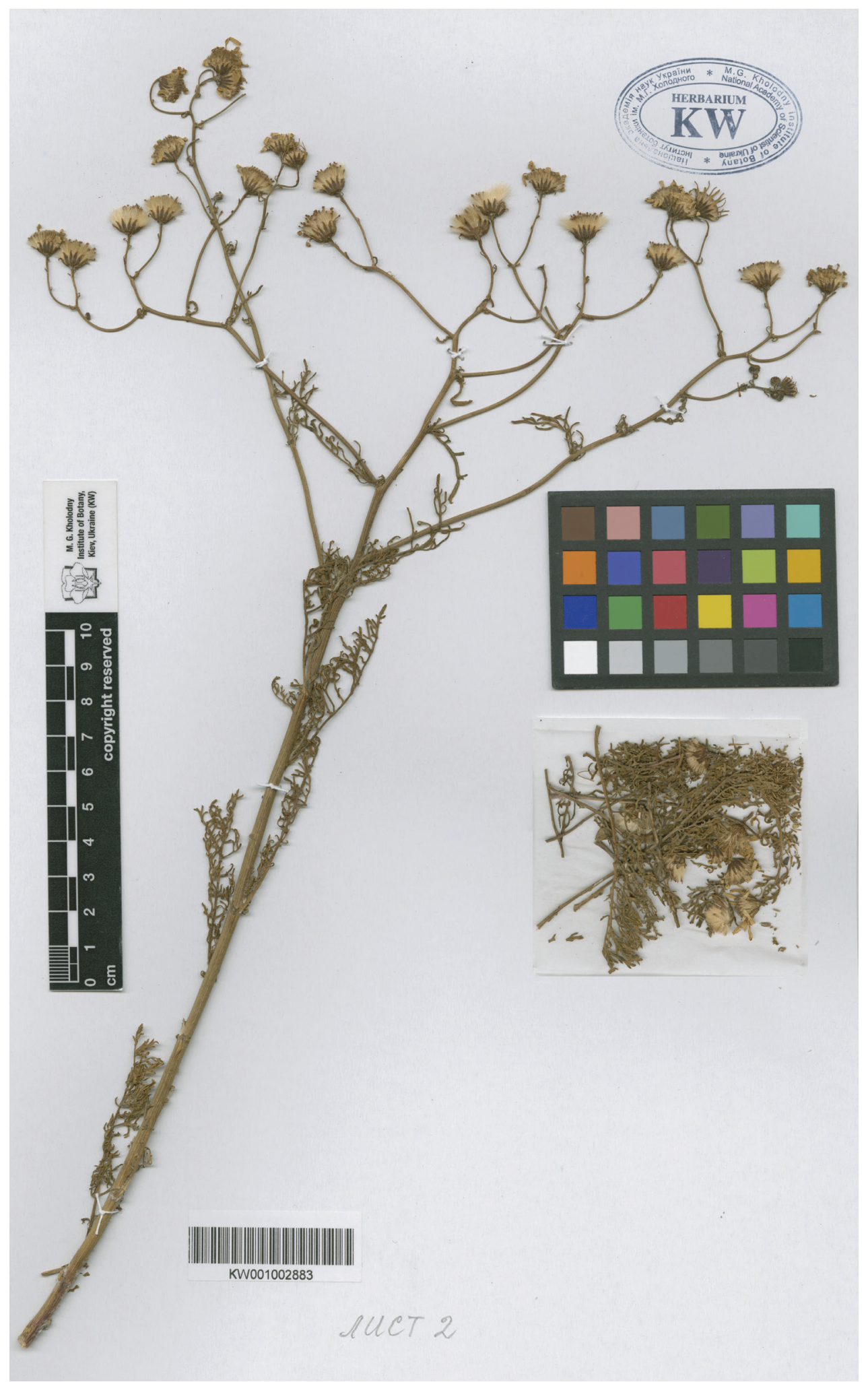

Figure 4E. The same specimen as in Fig. 3E, sheet 2 (KW001002883). 